\title{
The intracardiac renin-angiotensin-system : new insights in its role in cardiac hypertrophy and wound healing
}

Citation for published version (APA):

Passier, P. C. J. J. (1995). The intracardiac renin-angiotensin-system : new insights in its role in cardiac hypertrophy and wound healing. [Doctoral Thesis, Maastricht University]. Datawyse / Universitaire Pers Maastricht. https://doi.org/10.26481/dis.19951123pp

Document status and date:

Published: 01/01/1995

DOI:

10.26481/dis.19951123pp

Document Version:

Publisher's PDF, also known as Version of record

\section{Please check the document version of this publication:}

- A submitted manuscript is the version of the article upon submission and before peer-review. There can be important differences between the submitted version and the official published version of record.

People interested in the research are advised to contact the author for the final version of the publication, or visit the DOI to the publisher's website.

- The final author version and the galley proof are versions of the publication after peer review.

- The final published version features the final layout of the paper including the volume, issue and page numbers.

Link to publication

\footnotetext{
General rights rights.

- You may freely distribute the URL identifying the publication in the public portal. please follow below link for the End User Agreement:

www.umlib.nl/taverne-license

Take down policy

If you believe that this document breaches copyright please contact us at:

repository@maastrichtuniversity.nl

providing details and we will investigate your claim.
}

Copyright and moral rights for the publications made accessible in the public portal are retained by the authors and/or other copyright owners and it is a condition of accessing publications that users recognise and abide by the legal requirements associated with these

- Users may download and print one copy of any publication from the public portal for the purpose of private study or research.

- You may not further distribute the material or use it for any profit-making activity or commercial gain

If the publication is distributed under the terms of Article $25 \mathrm{fa}$ of the Dutch Copyright Act, indicated by the "Taverne" license above, 


\section{THE INTRACARDIAC RENIN-ANGIOTENSIN-SYSTEM}

new insights in its role in cardiac hypertrophy and wound healing 
Cover: Photomicrograph of a rat heart, 4 days after myocardial infarction "immunohistochemically stained with a goatmanti-rabbit angiatensin l-converting-enzyme (ACE)-antibody. ACE-immunoreactivity (black) is prediominantly present in endothelial cells in the border zone of the infarct area.

\section{CIP-DATA KONINKLIJKE BIBLIOTHEEK, DEN HAAG}

Passier, Petrus Christianus Johannus Jasephus

The intracardiac renin-angiotensin-system : new insights in its role in cardiac hypertrophy and wound healing / Petrus Christianus Johamnus Josephus Passier. Maastricht : Universitaire Pers Maastricht. - III. Thesis Rijksuniversiteit Limburg Maastricht. - With ref. ISBN 90-5278-202-4

Subject headings: intracardiac renin-angiotensin-system I hypertrophy / wound healing. 


\section{THE INTRACARDIAC RENIN-ANGIOTENSIN-SYSTEM}

new insights in its role in cardiac hypertrophy and wound healing

\section{PROEFSCHRIFT}

ter verkrijging van de graad van doctor aan de Rijksuniversiteit Limburg te Maastricht

op gezag van de Rector Magnificus, Prof. mr. M.J. Cohen, volgens het besluit van het College van Dekanen,

in het openbaar te verdedigen op donderdag 23 november 1995 om 16.00 uur

door

Petrus Christlanus Johannus Josephus Passler geboren te Bergen op Zoom in 1967

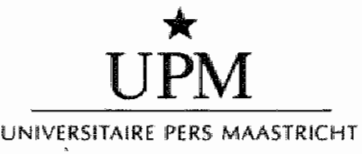




\section{Promotor}

Prof. dr. J.F.M. Smits

\section{Co-promotor}

Dr. M.J.A.P. Daemen

\section{Beoordelingscommissie}

Prof. dr. P.W. de Leeuw, voorzitter

Prof. dr. J.W. Arends

Prof. dr. H. Drexler, University of Freiburg, Germany

Prof. dr. T. Unger, University of Kiel, Germany

Prof. dr. H.J.J. Wellens

Financial support by the Netherlands Heart Foundation for the publication of this thesis is gratefully acknowledged

For financial support for the publication of this thesis we also thank:

- Dr Saal van Zwanenbergstichting

- Stichting Klinische Pathologie Zuid-Limburg 
Cause / gotta have faith...

G. Michael, 1984.

Aan mijn ouders

Voor Sylvia 



\section{CONTENTS}

\section{CHAPTER 1}

INTRODUCTION

1.1 General introduction

1.2 The renin-angiotensin-system

1.2.1 The circulating renin-angiotensin-system 12

1.2.2 Angiotensin receptors

1.2.3 Signal transduction systems coupled to AT receptors 16

1.2.4 The local RAS

1.2.5 The intracardiac RAS

21

1.2.6 Regulation of systemic RAS $\quad 24$

1.2.7 Regulation of the cardiac RAS 24

1.2.8 Functions of the intracardiac AAS $\quad 25$

$\begin{array}{lll}1.3 & \text { Cardiac remodelling } & 27\end{array}$

1.3.1 Cardiac hypertrophy in pressure-and volume overload 27

1.3.2 Changes in the infarcted left ventricle following myocardial infarction 27

1.3.3 Changes in the non-infarcted ventricle 28

1.3.4 Cellular changes in cardiac remodelling 28

1.3.5 Factors involved in the development of cardiac hypertrophy 30

1.4 The role of the RAS in cardiac remodelling 31

1.4.1 ACE-inhibition in cardiac hypertrophy 31

1.4.2 ACE-inhibition: effects on cardiac function following MI 32

1.4.3 AT receptor biockade in cardiac hypertrophy 33

1.4.4 Activation of the cardiac RAS in cardiac hypertrophy 34

1.4.5 The role of the RAS in cellular changes 35

HYPOTHESIS 38

THIS THESIS 38

CHAPTER 2

MATERIALS AND METHODS

2.1 Animals 58

2.2 Surgery 58

2.2.1 Myocardial infarction $\quad 58$

2.2.2 Bitateral nephrectomy 58

2.2.3 Abdominal aorta coarctation 58

2.2.4 Captopril treatment 58

2.3 Tissue processing 59

2.3.1 Morphometric analysis $\quad 59$

2.3.2 RNA isolation $\quad 59$

2.4 Competitive reverse transcriptase polymerase chain reaction 59

2.4.1 Selecting specific primers $\quad 60$

2.4.2 Internal standards $\quad 61$ 
2.4.3 Reverse transcriptase

2.4.4 Polymerase chain reaction

2.4.5 Quantification of the PCR fragments 63

2.5 Northern hybridization analysis 63

2.5.1 Labeling of CDNA and hybridization 63

2.5.2 Autoradlography $\quad 64$

$\begin{array}{ll}2.6 & \text { In situ hybridization }\end{array} 64$

2.7 Blochemical assays 65

2.7.1 Plasma angiotensin // concentration 65

2.7.2 Plasma renin activity $\quad 65$

2.7.3 Tissue ACE activity $\quad 65$

2.8 Immunohistochemistry 66

$\begin{array}{lll}2.9 & \text { Statistical analysis } & 66\end{array}$

CHAPTER 3

DIFFERENTIAL REGULATION OF ANGIOTENSINOGEN AND RENIN MESSENGER RNA FOLLOWING INTERVENTIONS IN THE RENINANGIOTENSIN SYSTEM IN RATS

$\begin{array}{lll}3.1 & \text { Introduction } & 70\end{array}$

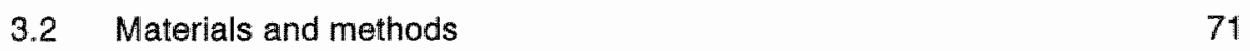

$\begin{array}{lll}3.3 & \text { Results } & 72\end{array}$

3.4 Discussion 76

\section{CHAPTER 4}

ACTIVATION OF ANGIOTENSIN I-CONVERTING-ENZYME GENE AND PROTEIN IN THE INFARCT ZONE FOLLOWING MYOCARDIAL INFARCTION IN THE RAT

4.1 Introduction 84

4.2 Materials and methods $\quad 85$

$\begin{array}{lll}4.3 & \text { Results } & 88\end{array}$

4.4 Discussion 92

CHAPTER 5

ACTIVATION OF THE RENIN GENE IN THE INFARCT ZONE FOLLOWING MYOCARDIAL INFARICTION IN THE RAT

$\begin{array}{ll}5.1 \text { Introduction } & 100\end{array}$

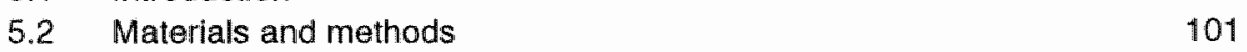

$\begin{array}{lll}5.3 & \text { Results } & 102\end{array}$

$\begin{array}{ll}5.4 \text { Discussion } & 105\end{array}$

CHAPTER 6

ANGIOTENSINOGEN MESSENGER RNA EXPRESSION IN THE

RAT HEART AFTER EXPERIMENTAL MYOCARDIAL INIFARCTION 111

6.1 Introduction 112

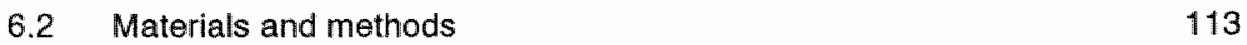

$\begin{array}{lll}6.3 & \text { Results } & 114\end{array}$

$\begin{array}{lll}6.4 & \text { Discussion } & 116\end{array}$ 


\section{CHAPTER 7}

INTRACARDIAC AND SYSTEMIC FEEDBACK REGULATION OF THE RENIN-ANGIOTENSIN-SYSTEM DURING EARLY CAPTOPRIL

TREATMENT FOLLOWING MYOCARDIAL INFARCTION IN THE RAT

7.1 Introduction

7.2 Materials and methods

7.3 Results

7.4 Discussion

CHAPTER 8. GENERAL DISCUSSION 133

8.1 Introduction 134

8.2 The existence of an intracardiac RAS 134

8.3 The intracardiac RAS versus the systemic RAS 134

8.4 Regulation of the intracardiac RAS and systemic RAS 136

8.5 Possible functions of the intracardiac RAS after myocardial infarction 138

8.6 The trigger for the activation of the intracardiac RAS after myocardial infarction

8.7 Conclusions and future outlook 141

SUMMARY

SAMENVATTING 


\section{LIST OF ABBREVIATIONS}

$\begin{array}{ll}\text { ACE } & \text { Angiotensin I-converting-enzyme } \\ \text { ACTH } & \text { Adrenocorticotrophic hormone } \\ \text { ANF } & \text { Atrial natriuretic factor } \\ \text { ANG I } & \text { Anglotensin I } \\ \text { ANG II } & \text { Angiotensin II } \\ \text { ANG III } & \text { Angiotensin III } \\ \text { ANG IV } & \text { Angiotensin IV } \\ \text { AO } & \text { Angiotensinogen } \\ \text { AT receptors } & \text { Angiotensin II-receptors } \\ \text { AT1 } & \text { Angiotensin II-receptor type I } \\ \text { AT2 } & \text { Angiotensin II-receptor type II } \\ \text { DNA } & \text { Deoxyribonucleic acid } \\ \text { MI } & \text { Myocardial infarction } \\ \text { mRNA } & \text { messenger ribonucleic acid } \\ \text { PCR } & \text { Polymerase chain reaction } \\ \text { PDGF } & \text { Platelet derived growth factor } \\ \text { RAS } & \text { Renin-angiotensin-system } \\ \text { RT } & \text { Reverse transcriptase } \\ \text { SDS } & \text { Sodium dodecylphosphate } \\ \text { SHR } & \text { Spontaneously hypertensive rats } \\ \text { SSC } & \text { Standard saline citrate } \\ \text { TGFB } & \text { Transforming growth factor } B \\ \text { WKY } & \text { Wistar Kyoto }\end{array}$


CHAPTER 1

INTRODUCTION 


\subsection{GENERAL INTRODUCTION}

Cardiac hypertrophy, defined as an increase in cardiac mass, is a powerful independent risk factor for cardiovascular complications $(46,171,196)$. Hypertension is an important determinant for the development of cardiac hypertrophy. Also myocardial infarction (MI) results in hypertrophy of the non-infarcted myocardium. This hypertrophic response of the myocardium and other changes in ventricular composition (e.g. cardiac fibrosis) and architecture (e.g. ventricular dilatation and ventricular wall thinning) are referred to as "cardiac remodelling". Although cardiac hypertrophy is, at first, an adaptive response compensating for the increased hemodynamic load and/or loss of viable contractile tissue, it eventually leads to a worsened cardiac function, resulting in a higher mortality and morbidity. Over the past half century it has been established that regression of hypertension-induced cardiac hypertrophy can be achieved by reduction of blood pressure by several classes of antihypertensive drugs $(66,69,76,131,198)$. However, it also became clear that blood pressure is not the only factor responsible for the development of cardiac hypertrophy. Comparisons of different classes of antihypertensive drugs demonstrated different effects on the regression of cardiac hypertrophy, while similar effects on blood pressure were observed $(69,131,198,296)$. Particularly anglotensin 1-converting-enzyme-inhibitors were found to be very effective in regressing cardiac hypertrophy, even without reducing the blood pressure (207). This suggested a role for the renin anglotensin system (RAS) in the development of cardiac hypertrophy. Tissue angiotensin II (ANG II) synthesis was suggested by the presence of ANG II in rat plasma after nephrectomy (3). In sheep and humans tissue ANG II synthesis was suggested by kinetic analysis of in vivo arterial-venous angiotensin | (ANG I) and ANG II differences (2,41). Indeed, components of the RAS have been detected in different organs, representing different functions. This is also true for the heart. The long-term responses to ACE-inhibitors, renin inhibitors and ANG II-antagonists are not predicted by plasma RAS activity $(40,331)$. This has led to the assumption that the level of ANG II within the tissue may be affected differently by these agents than ANG \| in circulating plasma and suggested the existence of a local RAS. ANG II has been shown to be a trophic factor for cardiac cells. All these arguments have led investigators to hypothesize that the intracardiac RAS is involved in the development of cardiac hypertrophy.

\subsection{THE RENIN-ANGIOTENSIN-SYSTEM}

\subsubsection{The clrculating renlin-anglotensin-system}

\section{Biochemistry}

The renin-angiotensin-system (RAS) has long been viewed as an endocrine system. 


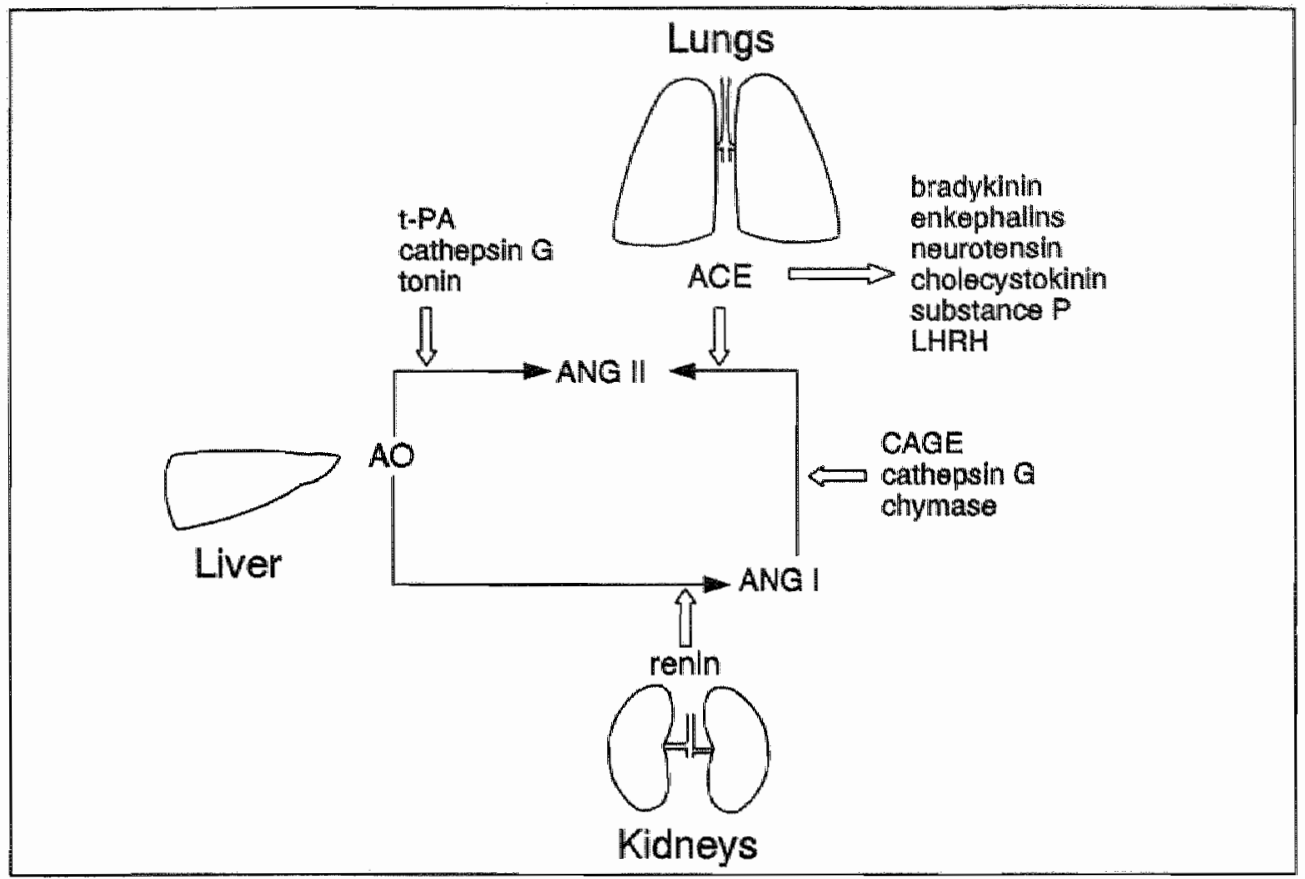

Figure 1. Pathways leading to ANG II formation. t-PA $=$ tissue-plasminogen activator: LHRH lutheinizing hormone releasing hormone; CAGE = chymostatim-sensitive angiotensin II-generating enzyme. $A O=$ angiotensinogen; $A C E=$ angiotensin 1 -comverting $-e n z y m e ; A N G \|$ angiotensin ; $A N G \|$ = angiotensin $\| l$.

The cascade of the circulating RAS starts with the production and secretion of the alpha-2 globulin, angiotensinogen $(A O)$, in the liver. In the juxtaglomerular apparatus in the kidney, specialized cells of the distal tubule, macula densa cells, produce the enzyme renin. Renin is first synthesized as a precursor molecule, prorenin, which is then converted into active renin in the Golgi apparatus or in granules (166). Renin is an aspartyl protease and catalyzes the rate-limiting step of the RAS. AO is cleaved by renin to form the decapeptide ANG I. ANG I is then transported by the blood to the lungs where it is converted by angiotensin l-converting-enzyme (ACE) at the membrane of endothelial cells to form the octapeptide ANG II, the biologically most active component of the RAS (figure 1). That the lung is the main organ for the conversion of ANG I to ANG II is explained by the high flow and the presence of large numbers of endothelial cells in this organ. In addition, ACE also occurs as a circulating enzyme in blood plasma, where it can convert ANG I to ANG II. ANG II is degraded by aminopeptidase $A$ and $B$ resulting in a heptapeptide, des-Asp ${ }^{3}$-ANG II (ANG III) and a hexapeptide des-Asp'-Arg'-ANG II (ANG 3-8 or ANG IV), respectively. A prolyl endopeptidase cleaves the heptapeptide des $P$ Phe ${ }^{\circ}$ ANG II 
(ANG 1-7) from ANG I. All these angiotensin peptides still possess biological activity, \|ike stimulation of aldosterone, vasopressin and prostaglandin synthesis by ANG II and ANG 1-7 (124). ANG IV exhibits biological activities that are opposite to those of ANG II and III $(223,341)$.

In addition to the classical pathway of ANG II formation, also other pathways of ANG II formation are possible. Tissue-plasminogen activator (t-PA), kallikrein, tonin, plasmin, cathepsin $G$, elastase and endothelium derived prorenin activating enzyme (EDPAE) convert prorenin in active renin $(283,302,305,336)$. Of interest, at least in humans, is chymase. This enzyme has been suggested to play a major role in ANG II formation $(319,320)$. Urata et al. observed that more than $75 \%$ of the ANG II forming enzyme activity in human left ventricular tissue homogenates was not blocked by ACE-inhibitors, but was blocked by the serine proteinase inhibitor chymostatin and soybean trypsin inhibitor (319). Subsequent studies showed that the major ANG II-forming serine proteinase from the human cardiac ventricles was chymase $(321,322)$. Furthermore, chymostatin-sensitive ANG II generating enzyme (CAGE), trypsin, cathepsin $G$, tonin, chymase and t-PA $(90,148,242,320)$ are all able to generate ANG II directly from AO or from ANG | (figure 1).

In addition to the cleavage from ANG I to ANG II, ACE has also been shown to cleave other peptides like bradykinin, enkephalins, neurotensin, cholecystokinin, substance $P$, and the gonadotrophin luteinizing hormone releasing hormone $(99,102,103,290)$.

\section{Physiology}

ANG II causes powerful arterial vasoconstriction and thereby it plays an Important role in blood pressure regulation. Furthermore, ANG II stimulates synthesis and release of aldosterone from the adrenal glands. This results in sodium and water retention in the kidney. Water retention results in an increase of blood pressure. ANG II has also direct effects on renal function. ANG || stimulates proximal tubular sodium reabsarption (136). Glomerular filtration rate, which is dependent of renal blood flow, glomerular pressure and the glomerular filtration coefficient, is affected by ANG II. The glomerular filtration coefficient is decreased by ANG II through constriction of mesangial cells (24). Vasoconstriction of efferent glomerular arterioles by ANG II increases filtration pressure. The balance of these factors determines the glomerular filtration rate.

Activation of the sympathetic nervous system by ANG II also plays a role in blood pressure regulation $(72,136,220)$. ANG II can facilitate the release of norepinephrine by a direct effect within the central nervous system. Alternatively, enhancement of sympathetic activity may also depend on stimulation of AT receptors on sympathetic nerve terminals, releasing norepinephrine. ANG II increases sympathetic outflow from the brain to both the vasculature and the myocardium (11). The rapid response of the circulating RAS on changes in fluid balance, blood flow and blood pressure provides immediate hemodynamic stability 


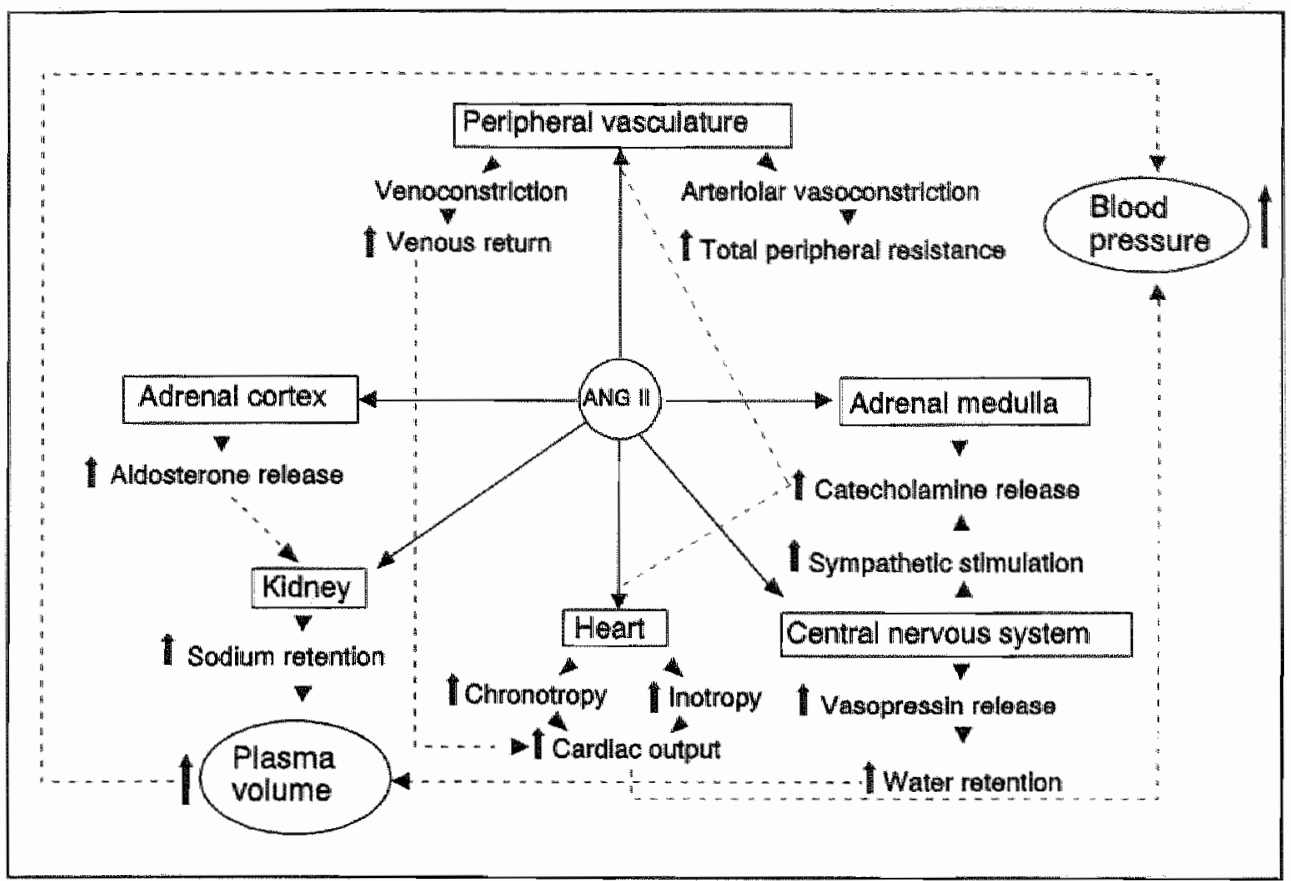

Figure 2. ANG $\|$-mediated functions. ANG $\|=$ angiotensin $\| ; ~ \dagger=$ stimulatory effect.

and prevents hypotension (figure 2). The principal function of the circulating RAS is to provide shortterm cardiorenal homeostasis. Except for states of severe cardiovascular decompensation, plasma renin-activity almost always returns to normal when homeostasis is achleved (89).

\subsubsection{Anglotensin receptors}

Differences in concentration-response relationship (248), binding properties for ANG $\|$-analogs $(82,130)$ and signal transduction systems (119) suggested the existence of different receptor subtypes for ANG II. One of the earlier reports on AT receptors was on the mas-oncogen product, expressed in xenopus oocytes (160). This mas oncogen product was able to open a chloride chamnel in response to ANG II when transfected into xenopus oocytes.

The avallability of selective compounds made it possible to identify the existence of at least two receptor subtypes for ANG II, defined as the AT1 and the AT2 receptor $(55,332)$. The pharmacological classification of AT1 and AT2 receptors was based upon different binding profiles for the non-peptidergiic ligands losartan (Dup 753) and PD123177 and the peptide CGP42112A. The anglotensin receptor that selectively binds losartan, was classified as the AT1 receptor (85), whereas 
selective binding of PD123177 and CGP42112A was classified as the AT2 receptor $(55,332)$. Further distinction between the AT1 and AT2 receptors is possible by the inhibition of the AT1 receptor and the potentiation of the AT2 receptor by dithiothreitol (DTT) $(56,261,294)$. Sasaki et al. (272) and Murphy et al. (228) cloned the AT1 receptor from bovine adrenal glomerulosa cells and rat aortic vascular smooth muscle cells, respectively. The AT1 receptor was found to belong to the seven-transmembrane-domain receptors superfamily and contains 359 amino acids $(228,272)$. The subsequent cloning of the AT1 receptor from the rat adrenal gland (154,271), showed an $8 \%$ difference in amino acid sequence when compared to the rat aortic AT1 receptor (228), which indicated a distinction between AT1 subtypes, the AT1a and the AT1b. A similar divergence between AT1a and AT1b has been found in humans $(182,188,217)$ (table 1).

The AT2 receptor was first cloned by Kambayashi et al. (170) and Mukoyama et al. (227) rat pheochromocytoma and rat foetus, respectively. These AT2 receptors contain 363 amino acids and belong to the seven-transmembrane-domain receptor family. The AT2 receptor displays a $32-34 \%$ homology with the AT1 receptor. The highest homologies are found in the putative transmembrane areas.

Another group of AT receptors differs substantially from the AT1 and the AT2 receptor. These AT receptors do not bind either losartan or PD123177. However, CGP42112A, another AT2 ligand, displayed a higher binding affinity than losartan and PD123177 for the AT receptor in radioligand binding studies (194). Binding sites for ANG II with these characteristics have been found in several tissues in different species, for example in the adrenal gland of the turkey, which has a $78 \%$ homology to the AT1 receptor (45) and in the chorioallantoic membrane (CAM) of the chick embryo (194).

In human isolated cardiac fibroblasts from explanted end-stage failing human hearts, ANG II induced cellular proliferation, which could not be inhibited by losartan, PD123319, and CGP41112A (Dr. Neuss, personal communication) suggesting the existence of an as yet unknown AT receptor subtype (237).

\subsubsection{Signal transduction systems coupled to AT receptors}

The AT1 receptor is coupled to at least five effector systems: phospholipase C, D, and A2, adenylate cyclase and calcium channels (table 2). The activation of phospholipase $\mathrm{C}$ resulting in an increase of intracellular $\mathrm{Ca}^{2+}$ has been demonstrated in vascular smooth muscie cells $(38,127)$. ANG $\|$ also activates phospholipase D $(189,190)$. Activation of phospholipase D may be involved in cell growth $(241,247)$. Activation of phospholipase A2 has been demonstrated in different cell types $(4,83,274)$ and results in free fatty acids, mostly arachidonic acid, and Iysophospholipids. Arachidonic acid is the precursor for the synthesis of prostaglandins and leukotrienes. Inhibition of adenylate cyclase activity by ANG II was found in rat liver membranes $(62,163,256)$, Leydig cells $(174)$, cultured bovine adrenal membranes and cardiac myocytes or membranes in rat and rabbit $(8,10)$. 


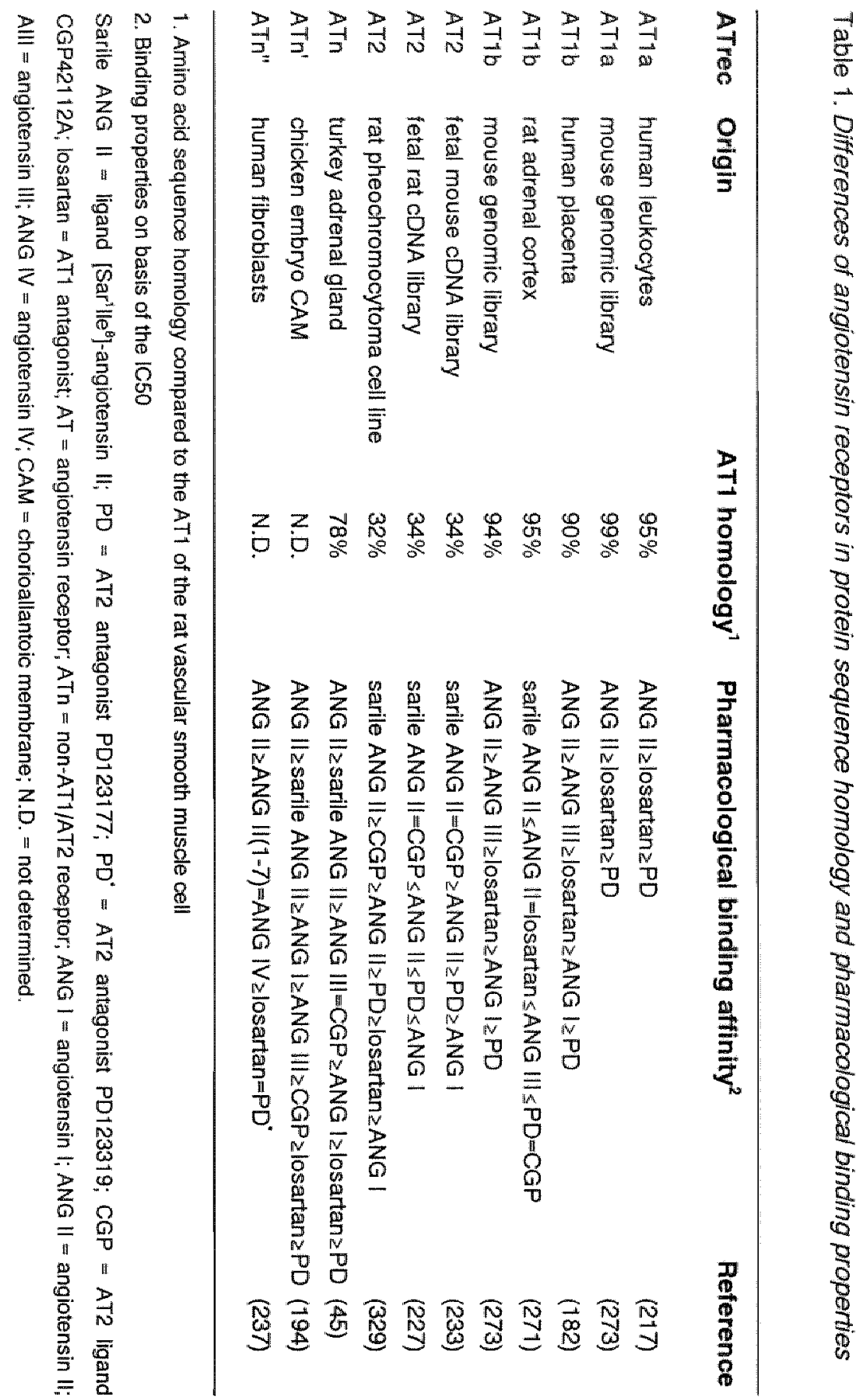


Table 2. AT1 receptor mediated signal transduction systems

\begin{tabular}{llll}
\hline Signal transduction & Tissuefcells & Species & Reference \\
I Phospholipase C & vascular SMC & rat & $(38,127)$ \\
I Phospholipase D & vascular SMC & rat & $(189,190)$ \\
I Phospholipase A2 & umbilical vein SMC & human & $(4)$ \\
& proximal tubular epithelium & rat & $(83)$ \\
& mesangial cells & rat & $(274)$ \\
$\downarrow$ Adenylate cyclase & liverladrenal/myocytes membranes & rat,rabbit & $(8,10,163)$ \\
& Leydig cells & rat & $(174)$ \\
1 Calcium channels & aortic microsomes & pig & $(31)$ \\
$\downarrow$ Potassium channels zona glomerulosa cells & rat, bovine, human & $(258)$ \\
\hline
\end{tabular}

SMC $=$ smooth muscle cells; $\uparrow=$ stimullation; $\downarrow=$ inhibition

Little is known about the signal transduction of the AT2 receptor subtype. In bovine cerebellum (36), human myometrium $(257,332)$, and in different cultured cell lines $(84,195,329)$ the AT2 receptor was expressed and was not coupled to G-proteins. In the rat brain two binding sites for the AT2 receptor were found. One was sensitive for $\gamma$ GTP(S), DTT and pertussis toxin, while the other was insensitive to these agents $(313,315)$. Furthermore ANG II was found to decrease or increase cGMP in neonatal rat brain cell cultures (298) and the N1E-115 cell line (343), respectively. AT2 receptors have also been shown to be involved in prostaglandin synthesis in human astrocytes (161). In rat pheochromocytoma PC12W cells, the AT2 receptor inhibited ANP-stimulated guanylyl cyclase through the activation of a phosphotyrosine phosphatase (35).

\section{Functions mediated via the angiotensin receptors}

Most known physiological actions of ANG II seem to be mediated through the AT1 receptor $(309,339)$. The most important AT1 receptor mediated functions are summarized in table 3 . In this thesis we focussed on the hypertrophic response of ANG II. ANG II-induced hypertrophy of the adult rat heart was mediated through the AT1 receptor (79). In rats following experimental $M \|$, losartan regressed cardiac hypertrophy (292).

Not much is known about AT2 receptor mediated functions of ANG II. Cogan et al. (60) demonstrated a reduction in bicarbonate, chloride and water absorption by proximal tubules in the rat in the presence of PD123177. Since the AT2 receptor is expressed transiently and at higher levels than the AT1 receptor in fetal developmental stages in different species $(125,222,314)$, it has been suggested that the AT2 receptor 
Table 3. AT1 receptor-mediated functions

\section{Function}

$\uparrow$ vasoconstriction

$\uparrow$ aldosterone secretion

$\uparrow$ catechollamine release

$\downarrow$ renin release

$\uparrow$ vasopressin release

1 GFR

$\uparrow$ cell growth

protein synthesis

thymidine incorporation

drinking

\section{Species}

rat, dog, human

rat, dog.

bovine, human

rat, dog

rat, monkey

dog, human

rat

rat

rat, human

\section{Reference}

$(58,59,337)$

$(49,59,134)$

$(58,110)$

$(338,339)$

$(5,121)$

$(58,59)$

(144)

(98)

$(1,57)$

rat

$1=$ stimulation; $1=$ inhibition; GFR = glomerular filtration rate

plays a role in the proliferation and differentiation of cells. In agreement, in infarcted rats treatment with the AT2-antagonist PD123319 inhibited DNA-synthesis in the non-infarcted septum when compared to untreated infarct animals, showing the involvement of the AT2 receptor in the regulation of interstitial DNA synthesis after MI. Recently, an antiproliferative effect for the AT2 receptor has been described (295). In cultured coronary endothelial cells from spontaneously hypertensive rats (SHR), ANG II inhibited basic fibroblast growth factor (FGF)-stimulated proliferation of the endothellal cells. This effect was prevented by PD123177 and CGP42112A (295).

AT1 as well as AT2 receptors have been described to be involved in the process of wound healing. A downregulation of the AT1 receptor (176) and an upregulation of the AT2 receptor (325) was observed in the rat skin after injury, suggesting that both the AT1 and the AT2 receptors are involved in the wound healling process. However, the precise role of ANG \|l in wound healing is not clear.

A different AT receptor, demonstrated in the CAM (vide supra), was involved in ANG $\|$-induced angiogenesis, also one aspect of the wound healing process. This effect could not be blocked by losartan and PD123319. However, CGP42112A could block the ANG II-induced angiogenesis in the CAM completely (194). Also in a nonAT1/AT2 receptor in human isolated cardiac fibroblasts from explanted end-stage failing human hearts induced cellular proliferation after stimulation with ANG II. This effect could not be inhibited by losartan, PD123319, and CGP41112A (Dr. Neuss, personal communication), suggesting the existence of an as yet unknown $A T$ receptor subtype (237). 


\section{2 .4 The local RAS}

In the last decade a new concept gained much interest. This concept involves, in addition to the circulating RAS, the existence of local renin-angiotensin-systems in a broad variety of tissues. The presence and synthesis of all components of the RAS, including AT receptors, in one organ is a prerequisite for reference as a local RAS. The evidence for the existence of these local renin-angiotensin-systems came from biochemical studies demonstrating the presence and activity of $A O$, renin-like enzymes, ACE, angiotensins and AT receptors in different tissues $(42,89,118,149$, 255). Localization of the different components of the RAS in these tissues was performed by immunohistochemistry and radioligand binding assays $(39,117)$. Although the presence and activity of the different components of the local RAS has been described, the uptake of these components from the circulation can not be excluded. Therefore, the prerequisite for the existence of a local RAS is the expression of the mRNA of the different components in these tissues. In a variety of tissues the production of the components at the mRNA level has been detected $(94,108,213)$. However, little is known about possible functions of these local reninangiotensin-systems. For the cardiovascular system it is thought that tissue RAS play a role in the long-term maintenance of the vascular and cardiac function and structure $(114,142,166)$. The existence of the components of the RAS in organs, which play an important role in cardiovascular control, such as the heart, brain, kidney, adrenal, and blood vessels supports that hypothesis.

Blood vessels: In large and small arteries, like aorta and mesenteric arteries, enzyme activity and mRNA expression of the components of the RAS could be detected. AO mRNA and protein were detected in the peri-adventitial layer, renin activity and mRNA were particularly localized in the smooth muscle cells and endothelial cells $(86,87)$, ACE mRNA and activity in endothelial cells (95), and AT receptors in smooth muscle cells. ANG II formation was demonstrated in the isolated rat hindlimb artery, in the absence of circulating renin (243). In addition, kinetic analysis of in vivo arterial-venous ANG I and ANG II differences in sheep and humans also supports the concept of vascular tissue ANG II production (2). Locally produced ANG II may influence vascular function directly via local hormonal effects or indirectly via modulation of norepinephrine release from sympathetic nerve endings. The vascular RAS may contribute to the regulation of vascular tone and blood flow and may be involved in the development of vascular hypertrophy (92).

Adrenal glands: $A O$, renin and $A C E$ mRNA and protein have been detected in the adrenal glands $(75,118,235)$. Also, AT receptors have been detected in the adrenal glands; the AT1 receptor primarily in the adrenal cortex, and the AT2 receptor is localized in the adrenal medulla $(49,50)$. Adrenal angiotensin in the rat is involved in regulation of aldosterone biosynthesis, since saralasin inhibits basal aldosterone secretion rate in isolated adrenal glomerulosa cells (335). In rats, aldosterone 
secretion is strongly correlated with adrenal renin activity (77). Increased adrenal renin activity was observed in SHR, suggesting a role for the adrenal RAS in the pathogenesis of hypertension.

Brain: $A O$, renin, ACE MRNA and AT receptors have been detected in the brain $(61,168,212,250,316)$. It has been suggested that $A N G$ II is primarily produced within neurones from neuronally synthesized $\mathrm{AO}$ (199). Total brain renin activity is regulated by factors independent of the circulating RAS (97). The brain RAS is possibly involved in blood pressure and thirst regulation as well as vasopressin and catecholamine release (117). Local ACE-inhibitor (ACE-1) treatment in the central nervous system resulted in reduction of the blood pressure and thirst, suggesting the involvement of a brain RAS in the thirst and blood pressure regulation (117).

Kidney: The demonstration of a 1000-fold higher ANG II concentration in the proximal tubular fluid than in plasma supports the existence of an intrarenal RAS (284). The intrarenal RAS may play a role in sodium reabsorption, $\mathrm{pH}$ regulation and glomerular hemodynamics (reviewed in (142)). AO mANA is localized in renal cortical proximal tubules (151). Renin mRNA is primarily lacalized in the juxtaglomerular cells $(133,307)$. Intrarenal ACE production has been demonstrated by the presence of ACE MRNA (267). ACE protein has been localized by immunohistochemistry in the brush border of the proximal tubule (47). In the proximal tubule, the site where ANG II is produced locilly, also AT1 and AT2 receptors are found (82).

\subsubsection{The Intracardlac RAS}

\section{Evidence for the existence of an intracardiac RAS}

The presence of AO mRNA has been demonstrated in hearts from several species $(26,94)$. AO mRNA concentration in the mouse heart was estimated to be $1 \%$ of mouse liver $A O$ mRNA concentration, the main source for $A O$ synthesis (94). AO MRNA and its translation product were also detected in isolated neonatal rat heart myocytes and fibroblasts ( 80$)$. In addition, the release of the $A O$ protein has been demonstrated in isolated perfused rat hearts (200). Renin mRNA was present in low quantities in the mouse and rat heart $(94,96,268)$, as well as in isolated neonatal rat heart myocytes and fibroblasts (80). In accordance, the presence of renin protein was demonstrated in isolated ventricular myocytes from rats using a specific renin antibody, suggesting that renin synthesis occurs in cardiomyocytes. Not only its presence, but also renin activity has been described in isolated cardiomyocytes of the rat and in homogenates of mouse and rat hearts (96). Furthermore, ANG 1generating activity was found in left ventricular tissue of the canine heart. It is, however, not known whether this activity is due to the effects of renin or other ANG I-forming enzymes, such as cathepsin D (132) (see paragraph 1.2.1). Danser et al. 
(71) showed evidence for angiotensin production in porcine cardiac tissue, although they concluded that cardiac renin is kidney-derived.

In addition to the cardiac $A O$ and renin, also ACE mRNA has been demonistrated in the heart of different species $(143,280)$. Furthermore, ACE protein was detected by immunofluorescent staining in rat neonatal cardiac myocytes, fibroblasts and endothelial cells $(81,342)$. In accordance, conversion from ANG | into ANG II by local ACE has been described in the isolated rat heart (204). Treatment with an ACE-I blocked this intracardiac ANG II-formation (208). In nephrectomized rabbits, with undetectable levells of circulating ANG II, treatment with an ACE-I resulted in lowered concentrations of atrial ANG I| (317), suggesting intraciardiac formation of ANG II by ACE.

AT receptors have been identified in the heart in different species. In the human heart the most predominant subtype is the AT2 receptor, whereas in animals the AT1 receptor subtype is present in higher densities. Sympathetic nerve terminals. (32), cardiomyocytes $(1,25,260)$, endothelial cells (295) and fibroblasts $(278,324)$ possess AT receptors. Whereas in coronary endothelial cells from rats AT1 and AT2 receptors are present (295), cardiac rat fibroblasts and myocytes exclusively express the AT1 receptor subtype (239).

Although data strongly suggest the existence of a locial intracardiac RAS, no direct biochemical evidence for its activity in vivo is available, since these data are difficult to obtain due to interference with the circulating RAS. The low levells of MRMA expression of the components of the cardiac RAS, especially renin mRNA expression, combined with the lack of in vivo data is the main reason why many researchers still question the function of an intracardiac RAS.

\section{Topography of the intracardiac RAS}

The topography of the components of the intracardiac RAS is summarized in table 4. In the adult rat, renin and AO mRNA have been detected in all compartments of the heart $(26,52,96,187,201)$, with the highest mRNA levels for both components in the atria $(96,187)$. However in neonatal rat hearts the highest renin and AO mRNA expression were found in the ventricles, with an overall lower level of renin mRNA expression (80). In the rat heart the highest concentrations of ACE were found in the valve leaflets (342). Furthermore high concentrations were detected in the coronary arteries and in the endothelial and adventitial layers of the aorta and pulmonary arteries. ACE concentrations were moderate in both atria and IOw in both ventricles (342). A high density of AT receptors was found in the atrioventricular (AV) node, in cells of the intracardiac ganglia and in parasympathetic nerve bundles. A moderate density was found in the AV bundle and low levels in the atria and ventricles (6). 

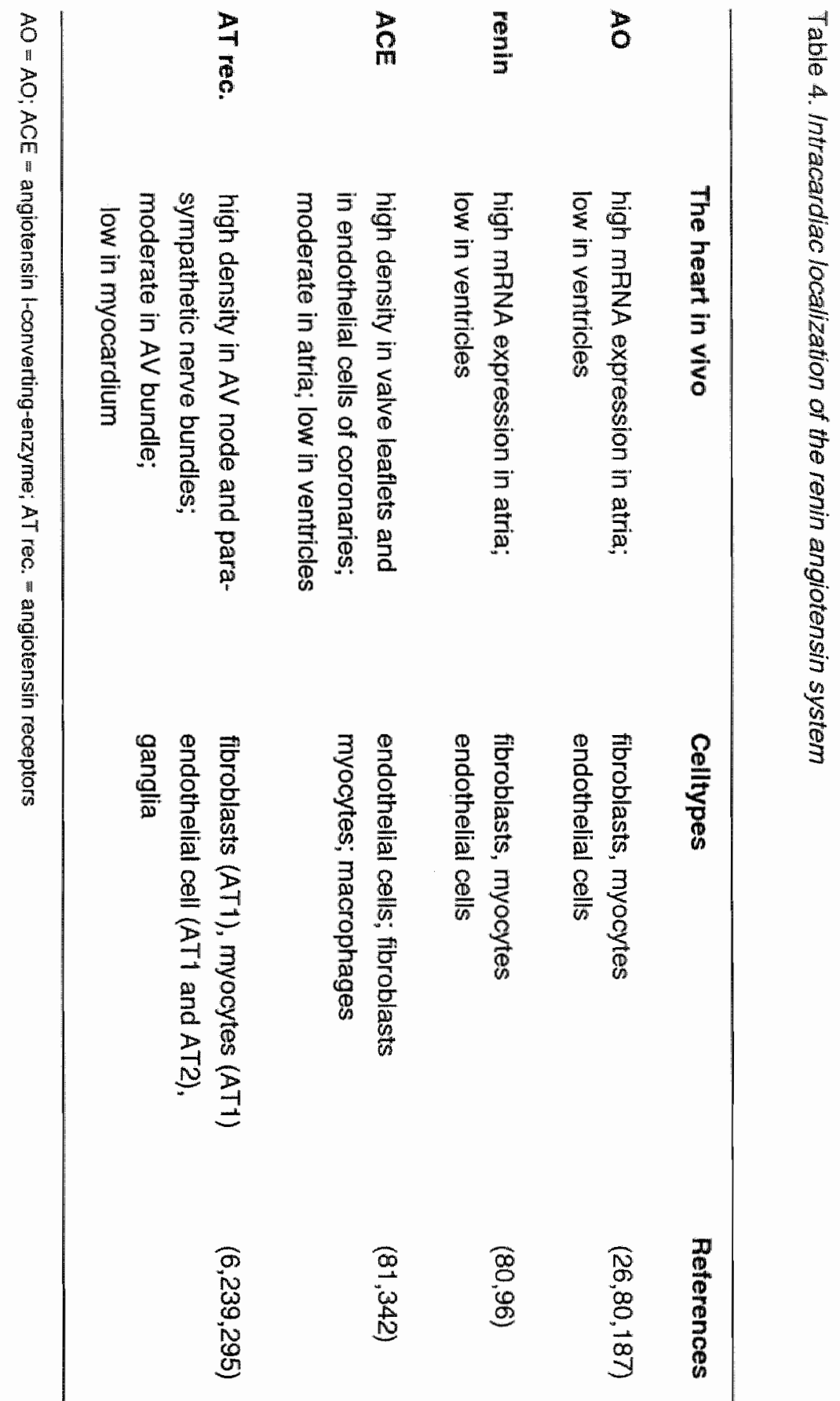


\subsubsection{Regulation of the systemic RAS}

Steroids $(48,101,141)$ and $A N G \|(28,140,175,282)$ upregulate the hepatic and the renal AO mANA expression in the rat, respectively (282). Stimulating effects of ANG II on AO MRNA expression were shown both at pharmacological and physiological ANG $\|$ concentrations (156). Besides ANG II, also renin has been suggested to modulate AO production. Administration of renin was associated with decreases in plasma and liver AO levels $(139,236,306)$.

Renal renin release is controlled by the sympathetic nervous system. Stimulation of B-adrenoreceptors on juxtaglomerular cells by sympathetic nerves or by circulating catecholamines increases renin release. Increases in renal perfusion pressure result in an inhibition of the renal release by intrarenal baroreceptors (11). ANG 11 -administration was shown to inhibit renal renin release and mRNA expression $(229,282)$. Furthermore, low sodium intake, sensed by the macula densa cells, has been demonstrated to increase renal renin mRNA expression and renal release $(11,268)$, whereas adrenocorticotrophic hormone potassium increase renin mRNA expression in cultured adrenal zona glomerulosa cells (328). Since renin is considered to be the rate-limiting enzyme, changes in activation of renin activity, has consequences for the complete systemic RAS.

Little is known about the regulation of the ACE gene. In addition to the effects on renin mRNA regulation, ANG II has also a negative feedback response on pulmonary ACE MRNA (281). This negative feedback of ANG II on ACE is also demonstrated by $A C E-I$ treatment, resulting in induction of plasma and pulmonary ACE activity $(115,159,281)$. Also glucocorticoids, thyroid hormones, androgens and $\beta$-adrenergic stimulation can increase $A C E$ activity in different tissues $(73,112,116$, 232,323). Furthermore increased as well as decreased ACE activity has been observed during hypoxia $(164,178)$.

ANG $\|$ is a potent factor in regulating mRNA expression and binding sites of AT receptors. In vascular smooth muscle cells ANG $\|$ decreased AT1 mANA by $50 \%$ (191) and in cultured rat ovarian granulosa cells AT2 binding sites were downregulated by ANG II. AT receptors in the anterior pituitary gland are downregulated by estrogen (51), which is primarily due to downregulation of the AT1b receptor mRNA expression. In contrast the AT1 a receptor was not affected by estrogen treatment (169). Differences in AT receptor subtype regulation were also observed in the rat brain during dietary sodium changes (270). Sodium depletion resulted in an increased expression of the AT1b receptor, whereas the expression of the AT la receptor was increased after a high sodium diet (270).

\subsubsection{Regulation of the cardiac RAS}

Effects of drugs on the intracardiac components of the RAS are summarized in table 5. Sodium depletion activates cardiac AO mRNA expression but not hepatic AO, indicating a tissue specific regulation (88). Glucocorticoids, which stimulate hepatic 
AO MRNA expression (vide supra), also increase AO mANA levels in the rat atria $(43,94)$ and ventricles $(94)$. The effects of ACE-I treatment on AO mRNA expression in the left ventricle of the rat are not clear. Both inhibitory (197) and stimulatory (26) effects have been described.

Increased cardiac renin mRNA levels and increased renin activity were observed in sodium depleted mice (93). Renal and adrenal renin expressions were also stimulated by sodium depletion, but submandibular or testicular renin expression were not, again indicating tissue specific regulation (93). In mice stimulation of $\beta$ adrenoceptors with isoproterenol increased cardiac and renal renin expression but not submandibular, testicular or adrenal renin in mice (96). Furthermore cardiac as well as submandibular renin levels were decreased after castration. Renin activity in cardiomyocytes of the rat was studied after treatment with different classes of antihypertensive drugs. After 7 days of treatment with a calcium blocker (nifedipine), ACE-inhibitors (CGS 14831, 14824A and 16617), a vasodilator (hydralazine) and a sympatholytic agent ( $\alpha$ methyldopa), myocytes were isolated from rat ventricles. While the ACE-inhibitors and the sympatholytic agent had no effect on renin activity, the calcium blocker decreased renin activity, and the nonspecific vasodilator increased renin activity $(88,96)$. However, in whole-heart homogenates renin activity was increased after treatment with nifedipine (262).

Little is known about the regulation of cardiac ACE and the AT receptors. In rat ventricles ACE activity was increased after treatment with calcium-blockers or diuretics (262). An in vitro study demonstrated increased cardiac, but not pulmonary ACE activity after treatment with the oxidizing agent diamide (311). The glucocorticoid dexamethasone resulted in an increase of AT1a mRNA levels in isolated cardiac fibroblasts, while it did not affect the AT1b receptor mRNA levels (216). These data indicate that the AT receptor subtype expression in the rat heart can be regulated in a subtype-specific matter.

\subsubsection{Functions of the intracardlac RAS}

ANG II has direct and indirect physiological effects on the heart. These include coronary vasoconstriction and increased inotropy and chronotropy $(29,251)$. Indirect effects are primarily due to modulation of the sympathetic nervous system. ANG II is known to facilitate adrenergic neurotransmission in the heart (29). The localization of the AT receptor in association with the sympathetic nervous system, supports the idea that ANG II exerts its effects, at least in part, indirectly. When sympathetic facilitation was avoided, dose-dependent positive inotropic effects of ANG II were demonstrated in isolated cardiac preparations in rats (234) and in isolated neonatal rat myocytes $(7,78,238)$. In humans ANG I and ANG $\|$ displayed positive inotropic effects via AT receptors in atrial preparations from failing and non-failing hearts, which could be completely blocked by saralasin. The positive inotropic effect of ANG $\|$ could be blocked by enalaprilate. However right and left ventricular preparations of these patients did not reveal positive inotropic actions of ANG I and 


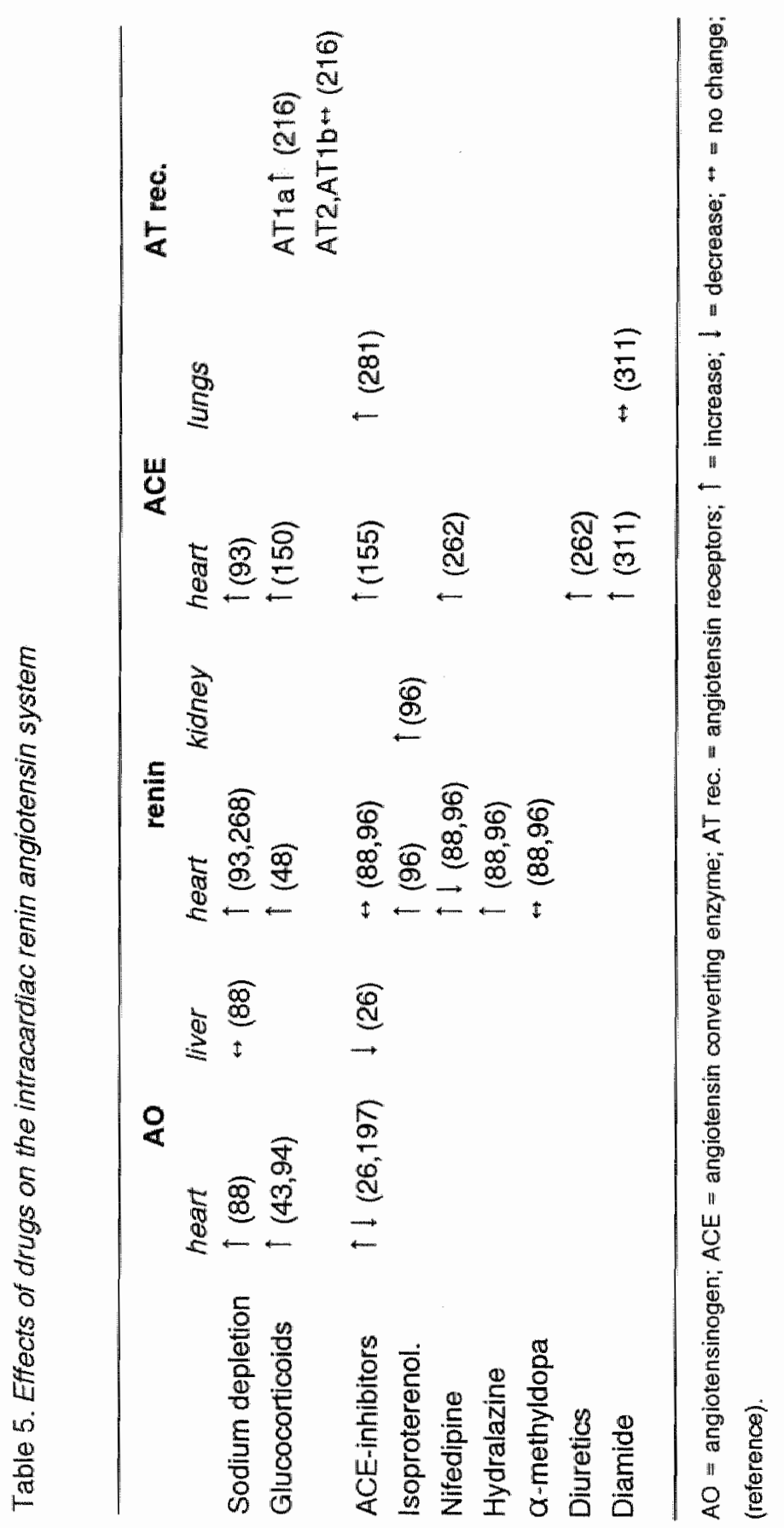


ANG II (145). The chronotropic effects of ANG II have been less consistent. In isolated atria from cats no chronotropic effects have been observed (181), whereas preparations from dogs (180), rabbits (308) and guinea pigs (345) demonstrated

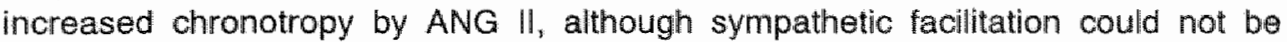
excluded in all experiments $(240,345)$. It is believed that the inotropic and chronotropic effects of ANG II on the cardiomyocyte are mediated by its effect on calcium homeostasis and transmembrane caicium conductance $(34,74)$.

In addition to the inotropic and chronotropic actions of ANG II, it may also play an important role in the regulation of cardiac growth, especially in the development of cardiac remodelling. This aspect of ANG II will be discussed below.

\section{3 CARDIAC REMODELLING}

\subsubsection{Cardiac hypertrophy in pressure- and volume overload}

Cardiac hypertrophy is defined as an increase of cardiac mass. Cardiac hypertrophy can be induced by pressure overload (prolonged), volume overload or a combination of both. It can also result from hyperthyroidism or from intensive exercise (physiological pressure overload). These latter two types of hypertrophy will not be further discussed here.

The hemodynamic overload as in hypertension leads to increases of ventricular wall tension. Accordance LaPlace"s law ( $T=P . r / 2 h$ : $T=$ tension; $P=$ pressure in the ventricle; $r=$ radius of the ventricle; $h=$ thickness of the ventricular wall) the cardiac response is directed to normalization of wall tension. Increased ventricular wall thickness as a response to increased ventricular pressure results in normalization of this wall tension. The pressure overload results in the devellopment of concentric hypertrophy, i.e. an increase in ventricular wall thickness, without increases of the inner ventricular radius (224). Parallel sarcomere replication produces the increased wall thickness.

In volume-overload hypertrophy, as in an aortacaval shunt, the increased ventricular wall tension, resulting from increased volume, is normalized by cardiac hypertrophy by addition of new myofibrils in series (end by end). This is defined as eccentric hypertrophy.

Although volume- and pressure overload both lead to cardiac hypertrophy, differences exist with respect to prognosis. Progmosis is better for volume overload hypertrophy than for pressure overload hypertrophy. These differences in prognosis may be caused by structural or phenotypical alterations.

\subsubsection{Changes In the infarcted ventricle following myocardllal Infarction}

After MI, necrosis of myocytes is followed by a wound healing response consisting of hypermeability (vasodilatation), an inflammatory reaction, fibroblast proliferation, increased deposition of extracellular matrix components, angiogenesis and the 
appearance of myofibroblasts (334). Funther cellular changes associated with the cardiac remodelling involve infarct expansion. As a result of the infarction the heart does not contract synergistically towards the center (dyskinesis). This stimulates thinning and expansion of the infarcted area $(147,253)$. Cellular changes responsible for the infarct expansion are the formation of wavy myocardial fibers as a result of inflammation and edema (109), a side to side slippage of myocytes, reduction and redistribution of cells across the infarcted zone $(16,245,333)$.

\subsubsection{Changes in the non-Infarcted ventricle}

After Ml, dilatation of the heart is a compensatory response to the loss of functional myocardium to maintain cardiac function $(104,218,253)$. This dilatation of the noninfarcted ventricle results in an increase of ventricular wall stress, which may further stimulate ventricular enlargement (253).

\section{Cardiac hypertrophy after myocardial infarction}

The loss of viable myocytes after MI results in an increased stroke work for the remaining myocytes. As soon as three days after $\mathrm{Ml}$ cellular hypertrophy has been observed in left and right ventricles, with a greater response of the left ventricle. Besides a $29 \%$ increase of volume of the viable myocardium, the left ventricular mean myocyte cell volume per nucleus and myocyte length were increased by $28 \%$ and $14 \%$, respectively (14). These changes are in accordance with characteristics of concentric as well as eccentric hypertrophy $(12,128)$. The functional changes in the non-infarcted left ventricle are referred to as eccentric hypertrophy, as occurs in volume overload hypertrophy. However the loss of myocytes increases the stress on the remaining myocytes, suggesting that this hypertrophy may be seen as a pressure overload hypertrophy. Right ventricular hypertrophy was demonstrated by a $21 \%$ increase in mean cell volume per nucleus, without changes in mean cell length (14). These differences in cell volume but not in cell length are typical for concentric hypertrophy produced by pressure overload $(15,17,128)$.

\subsubsection{Cellular changes In cardlac remodelling}

\section{Cardiac myocytes}

Approximalely one third of all cardiac cells are myocytes, which make up approximately $67 \%$ of the volume of the heart. After birth the myocytes are thought to be terminally differentiated; they have often been compared with neurons for their loss of capability of cell division (303), although it has been suggested in animals $(17,19,22,23,126,209)$ and humans $(245,246)$ that myocyte hyperplasia is possible in a variety of pathological conditions, including cardiac hypertrophy. As a result of pressure overload or the loss of viable myacytes, volume, orientation and possibly 
the number of myocytes change $(13,44,246)$. However, the increase in myocyte mass, does not fully compensate for the loss of viable tissue.

Cardiac hypertrophy is also associated with cellular changes in the cardio. myocyte. Upregulation of gene and protein of the contractlle protein, myosin light chain-2 has been observed in cardiomyocytes (192). Re-expression of the fetal phenotype is an important feature in the development of cardiac hypertrophy. For example, in rats the expression of $\alpha$ myosin heawy chain $(V 1)$, with a high myosin ATPase activity and rapid shortening velocity is switched to the expression of $\beta$ myosin heavy chain (V3), with a low myosin ATPase activity and slow shortening velocity (157). Furthermore also skeletal alpha actin $(30,210)$ and atrial natriuretic factor (ANF) MRNA are re-expressed. This re-expression of the fetal phenotype is associated with decreased contractility and lower energy demand of the cardiac muscle. This might explain the lack of functional improvement, in spite of an increase of myocyte mass.

The other cells in the heart like fibroblasts, endothelial cells, macrophages and smooth muscle cells (18) make up the largest number of cells, but only $33 \%$ of the total volume.

\section{Endothelium}

Proliferation of endotheliall cells in the myocardium suggests the formation of new, or the growth of pre-existing capillaries. Cardiac hypertrophy induced by physical exercise or by chronic hypoxia results in an unchanged or even increased capillary density in the myocardium (215). Cardiac hypertrophy induced by pressure overload also induces capillary angiogemesis. It, however, does not completely compensate for the magnitude of the cardiac hypertrophy (310). This is also true for cardiac hypertrophy induced by M: although growth of capillaries is observed in the noninfarcted myocardium, the ratio of capillaries to myocytes decreases (244). This increase in distance between capillaries impairs the diffusion of substrates, essential for the energetic processes in the hypertrophied myocardium. The re-expression of less energy consuming fetal contractile proteins in the (hypertrophied) myocardium may be seen as an adaptation for the impaired energy balance, although contractility is depressed $(172,291)$.

\section{Extracellular matrix}

The extracellular matrix in the heart is mainly composed of a collagen network. The collagen in the myocardium predominantly consists of the fibrillar collagens type I and III. The collagen network serves to tether the cardiac myocytes to one another, thereby influencing their contraction (330). An increase of the concentration of fibrillar collagen, also referred to as myocardial fibrosis, is a major determinant of myocardial stiffness and results in diastolic and systolic ventricular dysfunction (330). Furthermore, arrhythmias can occur as a result of the increased collagen 
deposition. This increase of collagen is a result of altered metabolic behavior and/or growth of cardiac fibroblasts (330).

Myocardial fibrosis occurs after $M I$ in the non-infarcted and infarcted myocardium $(183,221,326)$. Fibronectin, another component of the extracellular matrix, is increased after the induction of cardiac hypertrophy by MI $(269,288)$. Furthermore, an increase of DNA synthesis was observed in the interstitium after induction of $M$ in the rat within the first two weeks in the non-infarcted left and right ventricles. This increase of DNA synthesis was predominantly observed in fibroblasts and endothellal cells $(183,186)$.

In pressure-overload cardiac hypertrophy increased collagen concentrations have been demonstrated. This increase in collagen concentrations was correlated to the increase in pressure. In volume-overload hypertrophy no or a slight increase of collagen amounts were observed (137).

\subsubsection{Factors Involved In the development of cardlac hypertrophy}

In recent years it has become evident that several factors are involved in the development of cardiac hypertrophy. In vitro models demonstrated that a variety of factors, like basic FGF and transforming growth factor beta (TGFB), can induce hypertrophy of cardiomyocytes $(249,275)$. In addition, adrenergic agonists (179,344), endothelin-1 (289) and ANG II (25) elicit hypertrophic responses in cultured neonatal rat cardiomyocytes.

It has been proposed that mechanical factors, like stress, are involved in the development of cardiac hypertrophy. Stretch-induced hypertrophy of neonatal rat cardiac myocytes in vitro activated protein synthesis and gene transcription $(167,265,276)$. Furthermore, conditioned medium of stretched myocytes in culture resulted in activation of immediate-early genes and activation of second messengers in non-stretched myocytes (264). Sadoshima et al. (266) found an increase in c-fos, EGR-1, skeletal alpha actin and ANF MRNA expression and protein synthesis in stretched myocyles. Interestingly, these responses could be completely inhibited by an AT1 receptor blocker (losartan) or [Sar-1 IIe-8]ANG II, but not by an AT2 receptor blocker (PD123319). "n addition, the release of ANG II increased within 10 minutes after stretching the myocytes, which was associated with an upregulation of the AO gene 6 hours after stretching the myocytes. This shows that ANG II is an early mediator of the stretch-response in cardiac myocytes and may induce the hypertrophic response, either directly or indirectly by inducing other factors. Endothelin-1 may play a role in indirectly ANG $\|$-induced hypertrophy in cardiomyocytes (153). ANG II upregulated endothelin-1 mRNA levels in neonatal rat cardiomyocytes. Furthermore, endothelin-1 stimulated leucine incorporation into the cardiomyocytes, which was dose dependently inhibited by an endothelin $A$ receptor antagonist (BQ123) (153). 


\subsection{THE ROLE OF THE RAS IN CARDIAC REMODELLING}

\subsubsection{ACE-lnhibition in cardlac hypertrophy}

\section{ACE-inhibition in experimental studies}

There are several animal studies using different classes of antihypertensive drugs which show differences in reduction of cardiac hypertrophy, in spite of similar antihypertensive potency $(66,67,113)$. The ACE-I captopril, given from 6 -20 weeks of age, prevented the rise in blood pressure and cardiac hypertrophy in SHR. Treatment with the vasodilator dihydralazine also prevented the rise in blood pressure to the same extent as captopril, but cardiac hypertrophy was not prevented (207). ACE-inhibition regressed left ventricular hypertrophy in the two-kidney oneclip rat and in rats with aortic stenosis or banding $(184,285,286)$. Also in volume overload induced cardiac hypertrophy in rats regression of cardiac hypertrophy was observed after treatment with an ACE-1 (20). In this study volume overload hypertrophy was induced by an aortacaval fistula. After treatment with the ACE-1 perindopril for 1 month a regression of cardiac hypertrophy was observed (20). Following $M \|$ it was also shown that treatment with an $A C E-1$ resulted in regression of cardiac hypertrophy (252).

As mentioned before, the difficulty for abtaining evidence for the role of the intracardiac RAS in development of cardiac hypertrophy is the dissociation of effects of ACE-inhibitors on cardiac hypertrophy and blood pressure. However, Linz et al. (207) presented data supporting the role of the cardiac RAS in the development of cardiac hypertrophy in vivo. They compared the effects of equipotent antihypertensive doses of the ACE-I ramipril, the calcium antagonist nifedipine and the arterial vasodilator dihydralazine on cardiac hypertrophy in rats subjected to banding of the abdominal aorta after 6 weeks of treatment. In adidition to the hypertrophyregressing effect of these antihypertensive agents, the effect of a nonantihypertensive dose of ramipril (10 $\mu \mathrm{g} / \mathrm{kg} / \mathrm{day})$ was studied on regression or

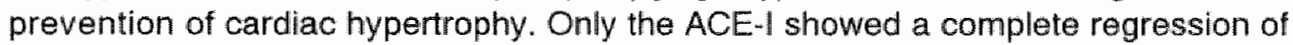
cardiac hypertrophy. Of interest was the similar effect on regression of cardlac hypertrophy observed after treatment with the low-dose ACE-I compared to the antihypertensive dose of the ACE-I, suggesting that other factors than blood pressure, like the RAS itself, are involved in the development of cardiac hypertrophy (207). However in SHR the ACE inhibitor enalapril was ineffective in regressing cardiac hypertrophy if the systolic blood pressure was not decreased $(123,318)$.

ACE-inhibitors have, in addition to the inhibiting effect of ANG II formation, also an effect on other systems, like the kallikrein system. Inhibition of ACE results in inhibition of the degradation of bradykinin. The role of bradykinin in cardiac hypertrophy and function was studled by Linz and Scholkens (206). They found that a bradykinin $B 2$ receptor antagonist, HOE 140 , could abolish the beneficial effects of an ACE-1 in rats with aortic banding, with respect to regression of cardiac 
hypertrophy and cardiac function. However, in another study, the antihypertrophic effects of the ACE-I ramipril in SHR were not attenuated by chironic treatment with HOE 140 (122). These data suggest that the beneficial effects of ACE-I may be caused by its effect on the kallikrein system or by a combined effect on the kallikrein system and the RAS.

\section{ACE-inhibition in clinical studies}

ACE-inhibition appears to be very effective in regression of cardiac hypertrophy, not only in hypertensive animals but also in hypertensive patients with cardiac hypertrophy $(21,91,100,111,231,279,287)$. The regression of cardiac hypertrophy, as was documented by echocardiography in these studies, is related to a decrease of left ventricular afterload $(91,287)$. However, not all antihypertensive drugs have the same efficacy with respect to regression of the cardiac hypertrophy. ACEinhibitors, $\beta$-blockers and calcium antagonists reduce left ventricular mass mainly through a reduction of wall thickness; ACE-inhibitors were found to be most effective (69). In a comparative long-term study, the ACE-1 enalapril, but not hydrochlorothiazide, reduced cardiac hypertrophy, although the blood pressure reductions in both treatment groups were comparable (68). Short-term treatment with ACEinhibitors, calcium antagonists, $\beta$-blockers and adrenergic agents all reduced cardlac hypertrophy, while $\alpha 1$-adrenergic receptor blockers, diuretics and vasodilators did not $(91,113,296)$. Again, these data indicate that the regression of cardiac hypertrophy is not onlly due to a reduction in hemodynamic overload.

\subsubsection{ACE-Inhibition: effects on cardlac function following MI}

The beneficial effects of ACE-I therapy have been shown in experimental and clinical studies. Pfeffer et al. demonstrated that captopril treatment in rats after MI resulted in improved cardiac function and survival $(252,254)$. In accordance increased survival was also observed with another ACE-1, enalapril, in rats after MI.

Also in large clinical trials the beneficial effects of ACE-I treatment after MI have been demonstrated. In the SOLVD (Studies of Left Ventricular Dysfunction) trial patients, of whom $65 \%$ had an MI, recelved enalapril or a placebo. Patients with unfarcts less than 4 weeks old were excluded from the trial (293). In the treatment group the risk of mortality was reduced by $16 \%$. In the AIRE (Acute Infarction Ramipril Efficacy) study treatment with the ACE-I ramipril was started in patients, 3 10 days after MI. The mortality risk in this study was reduced by $27 \%$ (135). In the Survival and Ventricular Enlargement (SAVE) study patients received the ACE-I captopril within 3-16 days of an acute MI (300). Patients, without clinical manifestations of heart failure, were followed for an average of 42 months. The study showed a $19 \%$ reduction in total cumulative mortality in the captopril treated group compared with the placebo group.

Although delayed treatment with ACE-inhibitors after MI clearly demonstrated 
beneficial effects on morbidity and mortality, clinical trials focussing on the treatment of pattents with an ACE-I in the early phase after MI were found to be less evident, which is in accordance with experimental studies. In experimental heart failure Schoemaker et al. (277) demonstrated depressed cardiac function when captopril treatment was given from 0-3 weeks after MI, however cardlac function was improved in the same study when captopril treatment was given from 3-5 weeks after MI. The Cooperative New Scandinavian Enalapril Survival Sudy II (CONSENSUS II) examined the effect of ACE-I treatment in 6090 patients with acute MI (301). ACE-I treatment with enalapril was started within 24 hours of the onsel of symptoms. The trial was terminated early (six months) because of the higher mortality rate in the treated group compared with the placebo group.

In the SMILE (Survival of Myocardial Infarction Longterm Evaluation) study 1556 patients were randomized to receive the ACE-I zofenopril or placebo within 24 hours of acute anterior MI not treated by thrombolysis. After 6 weeks the risk of mortality was reduced by $22 \%$, a difference which was not statistically significant. However, a significant reduction was observed in the frequency of refractory congestive heart fallure (9). In the CATS (Captopril and Thrombolysis Study) only patients within 6 hours of a first acute anterior MI were selected for treatment with the ACE-1 captopril. After 3 months no significant beneficial effects were found (106). In two megatrials GISSI-3 (Gruppo Italiano per lo Studio della Sopravivenza nell'Infarto Miocardico) (129) (18895 patients) and ISIS-4 (Fourth International Study of Infarct Survival) (152) (58050 patients) treatment with lisinopril or captopril, respectively, was started in patients within 24 hours of MI. Small differences (5-8 fewer deaths. per 1000 patients treated for 6 weeks or 12 months with lisinopril or captopril, respectively) between control and treated groups were found. In the Chinese cardiac Study (CCS-1) (54) 13634 patients up to 36 hours after the onset af suspected acute $M I$ were randomized between captopril or placebo treatment for one month. Approximately 5 fewer deaths per 1000 patients were obsenved after treatment with the ACE-I (a $5.6 \%$ proportional reduction in mortality).

The decrease of morbidity rate after early ACE-I treatment in patients with $M I$ in large clinical studies suggested, although data concerning early ACE-l treatment are not consistent after MI, that ACE-I treatment may start in the early phase in patients with $\mathrm{M} I(54,152)$.

\subsubsection{AT receptor blockade In cardllac hypertrophy}

The broad variety of actions of ACE (see paragraph 1.2.1), makes it difficult to ascribe the effects of ACE-inhibitors to the inhibition of ANG II. However, with the use of AT receptor antagonists, specific actions of ANG II can be examined. A significant regression of left ventricular hypertrophy was found in SHR after treatment with the AT1 antagonist losartan (225). This effect was greater than after ACE-inhibition (53). In another study losartan and captopril similarly prevented cardiac hypertrophy in SHA (226). Long-term treatment with the vasodilator minoxi- 
dil results in the development of volume-overload-induced cardiac hypertrophy in normotensive rats or humans $(193,312)$. In this model 5 weeks treatment with the AT1 antagonist losartan was more effective in regressing cardiac hypertrophy than enalapril (263). Also in cardiac hypertrophy following MI complete regression of hypertrophy was observed (292). Mizuno et al. (225) dlemonstrated that left ventricular ANG II content decreased after losartan treatment, while plasma ANG II concentration and plasma renin activity were increased, suggesting the importance of the intracardiac RAS in the development of cardiac hypertrophy. However in rats, subjected to aortic stenosis, resulting in pressure-overload hypertrophy, ACEinhibitors were more effective than AT1 antagonists in regression and prevention of cardiac hypertrophy $(185,205)$. In patients with symptomatic heart failure and impaired left ventricular function, short-term and long-term losartan treatment resulted in beneficial hemodynamic effects (64)

The distinct effects of regression or prevention of cardiac hypertrophy after blocking the RAS in several models of hypertrophy, suggest the involvement of different factors in the development of cardiac hypertrophy, like bradykinin (vide supra), chymase (not in rats), the involvement of AT receptors, or the involvement of local RAS versus the circulating RAS.

\subsubsection{Activation of the cardiac RAS in cardlac hypertrophy}

The intracardiac mRNA expression of components of the RAS in different models of cardiac hypertrophy is summarized in table 6 . The regression of cardiac hypertrophy by inhibitors of the RAS suggests that the activation of the RAS is changed in cardiac hypertrophy. In a pressure-overload model, induced by aorta constriction, AO mRNA was increased in atria and left ventricle, at 7 and 15 dlays after surgery, respectively (26). SHR, which develop marked cardiac hypertrophy, exhibit an increased cardiac expression of AO mRNA (197) when compared with Wistar Kyoto (WKY) rats. Similarly, MI resulted in an increase of AO mRNA in the non-infarcted left ventricle, 5 days after surgery. AO mRNA levels returned to base line at 25 days after infarction (202).

Little is known about the regulation of the renin gene in models of cardiac hypertrophy. In SHR an increased cardiac expression of renin mRNA was found in addition to the increased $A O$, when compared with $W K Y$ rats (203). In a volumeoverload hypertrophy model in rats, Leenen et al. (33) demonstrated an induction of left ventricular renin mRNA expression at 7 days after surgery, while there was no increase of cardiac AO mRNA expression.

Aorta constriction increases ACE mRNA (280) and ACE activity. In a semiquantitative study Hirsch et al. demonstrated a 2-fold increase in ACE MRNA expression in the right ventricle and septum 85 days after $M I$ in the rat. Studer et al. (297) used a competitive PCR for ACE and found a 3-fold increase in ACE MRNA amount in human failing hearts. No difference in chymase mRNA expression between the control hearts and the human failing hearts was found. In accordance 
Table 6: Activation of the intracardiac RAS in several animal models developing cardiac hypertrophy

\begin{tabular}{|c|c|c|c|c|c|}
\hline & $A O$ & renin & $\mathrm{ACE}$ & ATI & AT2 \\
\hline$A C$ & $\uparrow(26)$ & & & $\mid(280)$ & \\
\hline SHR & $\uparrow(197)$ & $\uparrow(203)$ & & & \\
\hline MI & $\uparrow(202)$ & & $\uparrow(297)$ & $\begin{array}{l}1(\text { AT1a })(239) \\
\leftrightarrow \leftrightarrow(\text { AT } 1 \text { b })(239)\end{array}$ & $\uparrow(239)$ \\
\hline vo & $\leftrightarrow(33)$ & $\uparrow(33)$ & & & \\
\hline
\end{tabular}

$\mathrm{AO}=$ angiotensinogen; $\mathrm{ACE}=$ angiotensin 1 -converting-enzyme; $\mathrm{AT} 1=$ angiotensin receptor type $1 ; \mathrm{AC}$ = arta coarctation; $\mathrm{SHA}=$ spontaneously hypertensive rats; $\mathrm{MI}=$ myocardial infarction; $\mathrm{VO}=$ volume overload; $\lceil$ = increase; $\mid=$ decrease; $\leftrightarrow$ = no change; (reference)

Fabris et al. (105) found an increase of ACE activity in different compartments of the rat heart by radioligand binding studies, 4 weeks after MI. The highest increases of $A C E$ activity were found in the infarcted area when compared to the sham-operated controls. In humans, Danilov et al. (70) found an increase of ACE immunoreactivity in the inflammatory zone of the infarcted left ventricle 7 days after MI.

Reiss et al. (259) isolated cardiomyocytes at 2-3 days after induction of experimental $\mathrm{MI}$ in rats. They found a 6 - and 2-fold increase of AT receptor MRNA, without making a distinction in receptor subtypes, in left and right ventricular myocytes, respectively. Similarly, in rats a 2-fold increase of AT receptor mRNA expression, predominantly the AT1 receptor, was found 7 days after MI in left and right ventricular myocytes. This was associated with an increased ANG II-stimulated phosphoinositol turnover in these cells (219). In the rat heart Nio of al. (239) demonstrated an increase of AT1a and AT2 receptor mRNA expression and number of receptors 7 days after MI. Highest increases were observed in the infarcted left ventricle. AT1b receptor expression was not affected by MIL. Treatment with an AT1 antagonist (TCV-116) reduced the increased mANA levels of the AT1a and AT2 receptors after MI, whereas treatment with an AT2 antagonist (PD123319) had no effect on AT receptor mANA levels, suggesting an AT1 receptor dependent feedback mechanism for the upregulation of the AT1a and AT2 receptors after MI (239).

\subsubsection{The role of the RAS in cellular changes}

Cardiac myocytes

Khairallah et al. (173) demonstrated that ANG II, without raising blood pressure, induced left ventricular hypertrophy in the rat. Baker and Aceto (25) demonstrated 
an increase of protein synthesis and cell growth in cardiac myocytes after addition of ANG II. This effect was inhibited by saralasin. In the adult rat heart, in vivo, it was shown that the thypertrophic action of ANG II was independent of its effects on blood pressure and mediated entirely through the AT1 receptor (79). Furthermore, ANG II induces the expression of the proto-oncogenes $\mathrm{c}-m y \mathrm{c}, \mathrm{c}$-fos and $\mathrm{c}$-jun in the heart and other growth-related factors such as early growth response gene (EGR1), and TGFB1 (158). In addition, ANG II increases cardiomyocyte DNA-, RNA- and proteinsynthesis and content within 2-3 hours after incubation (173). As discussed earlier, stretch may be an important stimulus for the development of hypertrophy of cardiomyocytes by releasing ANG II.

\section{Extracellular matrix}

Another possible pathophysiological role of an activated intracardiac RAS is its involvement in the formation of fibrous tissue. This, in turn, increases cardiac stiffness and depresses cardiac function. Neonatal rat cardiac fibroblasts displayed a mitogenic response in the presence of ANG $\|$ (278). This response was mediated by the ATI receptor. In accordance with this study, AT receptors were identified on neonatal and adult rat cardiac fibroblasts (324). Johnson and Aguilera (165) demonstrated in freshly isolated fetal rat skin fibroblasts that both AT1 and AT2 receptors were present, with the AT2 receptor as the most predominant AT receptor subtype. However, the proportions of the AT receptor subtypes tended to reverse during culture, with the AT1 receptor as the most predominant AT receptor at day 6 . ANG II induced, again via the AT1 receptor, the mRNA expression of the extracellular matrix components, collagen (type I and III) and fibronectin (63). Chronic ANG II infusion in rats at sub-pressor doses induced fibrosis, even after only two days of treatment (304). The collagen synthesis after $M I$ in the rat could be inhibited by ACE-I treatment $(183,221)$ or AT1 receptor blockade (292). In a chronic aorta coarctation model in rats ( 6 weeks) treatment with the ACE inhibitor enalapril resulted in regression of cardiac hypertrophy and a downregulation of type III collagen (214). The presence of ACE in tissue that is largely composed of collagen, like the heart valves, the adventitia of large vessels and intramyocardial arteries, corroborates the role of the RAS in formation of fibrous tissue. Sun et al. (299) found a high-affinity ACE binding in microscopic scars and perivascular fibrosis in the myocardium and atria after chronic treatment (4 and 6 weeks) with ANG II or aldosterone. The fact that inflammatory cells have not been observed in the vicinity of intramural vessels during the process of perivascular fibrosis, made them suggest that stimulation of fibroblasts could lead to production of ACE.

\section{Wound healing}

A role for the RAS in wound healing has been suggested before. ANG II in wound healing may depend on its ability to stimulate growth factors, like platelet derived 
growth factor (PDGF) and TGF $\beta$. It has been demonstrated that ANG II is able to induce the expression of growth factors PDGF and TGF $\beta$ in vascular smooth muscle cells $(120,230)$. A paracrine/autocrine stimulation of TGFB or PDGF by ANG II may be involved in the wound healing process. A role of ANG II in wound healing has been suggested in the rat skin. During experimental wound healing in the adult rat, ANG II levels increased in the skin as early as 6 hours with a peak (10-fold increase) at 24 hours after injury (177), which was associated with a downregulation of the AT1 receptor during the initial 12-24 hours after wound healing. However, another study demonstrated an increase of AT receptors, mainly the AT2 receptor, in the same model of wound healing (325). Thus, both AT1 and AT2 receptor may be involved in the process of wound healing. Also in the heart activation of the RAS has been observed during wound healing. In the infarcted area increased amounts of ACE protein were found in the inflammation zone of scars of human infarcted hearts, 3 and 7 days after MI (70). In accordance, 4 weeks after experimental MI in the rat, increased ACE binding was observed in the infarcted left ventricle (105). The RAS is also involved in vascular injury. After balloon catheter denudation ANG II stimulated DNA synthesis of smooth muscle cells (65). In accordance, Janiak et al. (162) demonstrated suppression of myointimal thickening in balloon denudated rabbits after treatment with the ACE-I perindopril or losartan.

\section{Endothelial cells}

MI results in an increase of DNA-synthesis in the myocardium (183). About $30 \%$ of the proliferating cells in the myocardium are endothelial cells (186), which suggests vascular growth. The remaining proliferating cells are most probably mainly fibroblasts, which can produce matrix proteins. The AT1 receptor antagonist, losartan, could only partially inhibit proliferation. However, collagen synthesis was completely blocked by losartan (292). This suggests that the endothelial proliferation is mediated via another pathway. In accordance with this is the observation on the regulation of ANG II-induced angiogenesis in the CAM (194). This response could not be blocked by the AT2 antagonist PD123319 and the AT1 antagonist losartan, whereas the AT2 receptor ligand CGP42112A completely reduced the ANG IIinduced angiogenesis (194). These data suggest the involvement of an AT receptor, different from the AT1 as well as the AT2 receptor, in the angiogenic response. In addition ANG II induced the formation of collateral vessels in the rat kidney in aortic stenosis (106) and the formation of new blood vessels in the rabbit cornea (107), supporting the hypothesis that ANG II is involved in angiogenesis. In agreement with these findings it has been reported that the ACE-I captopril reduces outgrowth of microvessels in the cremaster muscle of renal hypertensive and normotensive rats (327). In contrast with these findings is the increased myocardial capillary density after long-term treatment of SHR with the ACE-inhibitors ramipril or spirapril (318). Differences in the existence of the AT receptor subtypes may be an explanation for the differences in the effect ANG II in the angiogenic assays. 


\section{HYPOTHESIS}

Above we discussed the RAS and its role in the development of cardiac hypertrophy and other aspects of cardiac remodelling. Cardiac remodelling and especially cardiac hypertrophy are associated with higher morbidity and mortality rates, and it is therefore crucial to obtain more insights in the process of cardiac remodelling in pathological circumstances. In the last decade the concept of an intracardiac AAS and its role in heart failure have gained an acceptance. Little is known about the regulation of the intracardiac RAS in pathological conditions resulting in cardiac hypertrophy. Knowledge about the regulation of this intracardiac RAS in pathological conditions may give insights in the possible functional significance of an intracardiac RAS. Studies of activation of the intracardiac RAS at the mRNA and protein level may provide answers on a possible autocrine/paracrine role of the intracardiac RAS and/or its relation to the circulating RAS in these pathological conditions. This thesis describes studies on the activation and regulation of the intracardiac RAS in experimental models of cardiac hypertrophy, such as abdominal aorta coarctation and MI.

Our working hypothesis was that the intracardiac RAS is an important modulator of the development of cardiac hypertrophy.

\section{THIS THESIS}

In this thesis we studied the role of the intracardiac RAS in the development of cardiac hypertrophy by investigating the expression of the RAS in different models of experimental cardiac hypertrophy in the rat. Gene transcription of the different components of the RAS was measured by quantifying the MRNA expression using a reverse transcriptase competitive PCR. Localization of mRNA and its protein was performed by in situ hybridization and immunohistochemistry, respectively. Furthermore, RAS activity was measured in plasma and tissue. Studies were performed in a rat aortic coarctation model, a model of hypertension-induced cardiac hypertrophy and in a rat $\mathrm{MI}$ model. The experimental $\mathrm{MI}$ model offers an opportunity of studying the wound healing process and the hypertrophic response in one model.

In the first experimental chapter (chapter 3) we studied the regulation of the expression of angiotensinogen and renin in the heart and other tissues after different interventions, like captopril treatment, nephrectomy and abdominal aorta coarctation, resulting in different plasma levels of the circulating RAS. In the chapter 4, 5 and 6 we describe the activation and localization of ACE, renin and AO mRNA in the different compartments of the myocardium at different times after MI, respectively. In chapter 4 tissue ACE protein and activity was studied in the compartments of the rat heart at different times after MI. In chapter 7 we studied the feedback regulation of the expression of the $A O$, renin and $A C E$ in the heart and systemic organs (liver, kidneys, lungs) after MI during early captopril treatment. In chapter 8 the findings are discussed. 


\section{REFERENCES}

1. Aceto JF. Baker KH. [Sart) ]angiotensin II receptor-mediated stimulation of protein synthesis in whick heart cells. Am J Physiol 1990; $258.4806-4813$.

2. Admiraal PJ, Derkx FH, Danser Ail, Pieteman $H_{*}$ Schalekamp MA. Matabolism and production of angiotansin I in difterent vasiculer beds in subjects whthypentension. Hypertension $1990: 15: 44-55$.

3. Aguilera $G_{1}$ Schirer A, Baukai $A$, Get KW. Circulating anglotensin ll and adrenal recoptors after nephrectomy. Mature 1981; 289:507-509.

4. Alexander RW, Gimbrone MAJ. Stimulation of prostaglendin E synthesis in cultured human umbilical vein smooth muscle cells. Proc Naz Acad Sa US A 1976; 73:1617-1620.

5. Ahenc-Gelas $F$, Soubiter $F$, Hubert $G$. Alleguni $\downarrow$, Corvol $P$. The peculler characteristics of the amino acid sequence of angiotensin I-converting enzyme, as determined by cDNA cloning of the human endothelial enzyme, w Candiovasc Phamacol 1989; 14 (SUppl. 4):S6-S9.

6. Allen AM, Yamada H. Mendelsohn FA, In vitro autoradiographic localization of binding to anglotemsin receptors in the rat heiart. Int $₫$ Cardiol $1990 ; 28: 25-33$.

7. Allen is, Cohen NM, Dhallan RS, Gat ST, Lederer WJ, Rogers TB. Angiotensin II increases spontaneous contractile trequency and stimulates calcium current in cultured neomatal rat heart myocytes: ins lights into the underlying blochemicel mechanisms. Crc Res 1988; 62:524-534.

8. Alten IS, Gaa ST, Rogers TB. Changes in expression of a functonal Gi protein in cultured rat heart ceils. Am J Physion 1988; 255:C51-C.59.

9. Ambrosioni $E$. Borghi $C$, Magnani $B$. Early treatment al acute myocardial infarction with angiotensinconverting enzyme inhibition: satety considerations. SMILE pilot study working party. Am J Cardiol 1991" 68:101D.110D.

10. Amand-Srivastava MB. Anglotensin: II receptors megatively coupled to adenylate cyclase In rat myacardial sercolemme. Involwement of inhibitory guaning nucleotide regulatory protein. Biochem Pharmacol 1989 : $36: 489-496$.

11. Antonaccio MJ!, Wright ${ }^{4}$. Menin-angiotensin system, conventing enzyme, and renin inhibitors. In: Antonaccio Mh, ed. Cardiovascullair pharmacology. 3rd ed. New York; Riawen Press, 1990:201-228.

12. Anversa $P_{\text {" }}$ Beghi $C$, Levicky $V$, MCDonald $S L$. Kikkawa $Y$. Morphometry of right ventricular hypertrophy inducad by strenuous exercise in rat. Heart Circ Physiol 1982; $12:-H B 56-4861$.

13. Anversa P. Fitzpatrick D. Argani S. Capusso. JM. Myocyte mitolic disision in the aging mammellian rat hourt. Circ Pros 1991:69:1159-1164.

14. Anversa P. Loud AV. Levicky V. Guideri $G$. Left ventricular failure induced by myocardial intarction. I. Myocyte hypertrophy. An J Physiol $1985 ; 248: 4876-1882$.

15. Anverse P. Meissarl M. Beghi $C$. Olwett G. Structural compensetory mechanisms in rat hear in early sponteneous hypertension. Am J Physiol 1984; 246:H739-H746.

16. Amversa $P$, Oliwetti $G$, Capasso. JM. Cellular basis of ventricular remodeling atter myocardial infarction. Am of Cardial 1991:68:7D-16D.

17. Anversa $P$, Olwetti $G$. Loud VA. Morphometric atudy of early posthatal development in the lett and right ventricular myocardium of the rat. I. Hypentrophy, hyperplasia and binucleatlon at myocytos. Circ Fos 1980; 46. $495-502$.

10. Anversa $P$. Olivetti $G_{3}$ Melissari $M_{*}$ Loud $A V$. Stereological measurement of cellular and subcelluiar hypertrophy and hyperplasia in the papillary muscle of adult rat. $J$ Mot Call Cardiof 1980; 12:781-795.

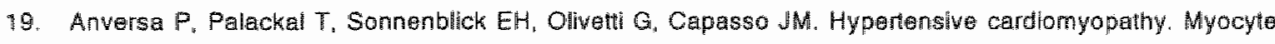

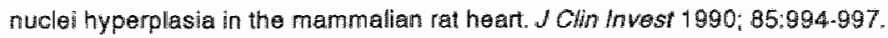

20. Amal JF, Philippe M, Laboulandine I, Michel JB. Effect of perindopril in rat cardiac volume overload. Am Heant $/ 1993 ; 126: 776-782$. 
21. Asmar RG, Panniar B, Santonil JP, Laurent S, London GM, Levy BH, Salar ME. Rleversion of cardiac hypertrophy and reduced anterial compliance after converting enzyme inhibition in assential hypertension. Circulation $1988 ; 78.941 .950$.

22. Astorn $E$, Bolognesi $R_{1}$ Colla $B$, Chizzola $A$, Visioli $O$. Left ventricular hypertrophy: a cytometric study on 42 human hearts. I Mor Celi Cardial 1977, 9:763-775.

23. Astorn E, Chizzola A, Vimioll $O$. Anversa P. Olvett G, Vitallimassa L. Right varutricular hypartrophy: a cytometric study on 55 human hearts. J Mol Cell Cardiol 1971, 2.99-110.

24. Ausiello DA, Kreisberg Jl, Foy $\mathrm{C}$. Contraction of cultured rat glomerular cells of apparent mesangial origin after stimulation with angiotensin II and arginine vasopressin. J Clin Anvest 1980; 65:754-760.

25. Eaker KM, Aceto JF. Angiotensin II stimulation of protein synthesis and cell growth in chick heart cells. Am J Phystor 9980; 258:H610-W618

26. Saker KM, Chernin MI. Wixson SK, Aceto JF. Aenin-anglotensin system involvement in pressure-overload cardlac hypentrophy in rats. Am I Physiol 1990; 259:H324.H332.

27. Begeot M, Langlois D, Penhoat A. Saez JM. Variations in glianine-binding proteins (Gs, G) in cultured bovine adrenal cells. Consequences on the effects of phorbol ester and anglotensin il on adrenocorticotropin-induced and cholera-toxin-induced CAMP production. Eur \& Biachem 1988: 174:317. 321.

28. Bem-Arl ET, Garrison $J C$. Regulation of angiotensinogen mFNA accumulation in rat hepatocytes. Am $A$ Physiol 1988; 255:E70-E79.

20. Ben.Ari ET, Lynch KA, Garrison JC. Glucocorticoids induce the accumulation of novel angiatensinogen gene transcripts. J Biol Charn 1989: 264:13074-13079.

30. Wishopric NH. Kedes L. Adrenergic regulation of the skeletal alpha-actin gene promoter cluring myocardial cell hypertrophy. Proc Nat Acad SciU S A 1991; 88;2132-2136.

31. Blayney LM, Gapper PW. Newby AC. Vasoconstrictor agonists activate G-protein-dependemt receptoroperated calcium channels in pig aortic microsomes. Blochem $J 1992 ; 282: 81-84$.

32. Blumberg AL; Ackerly JA, Peach MJ. Differentiation of neuragenic and myocardial angiotensin II receptors in isolated rabibit atria. Circ Res 1975; 38:26-30.

35. Boer PH, Ruzicka M, Loar W, Harmsen E Rosenthal J. Leenen FHH. Stretch-mediated activation of cardiac renin gene. Am J Physiol 1994: 267:H1630.H1636.

34. Bonnardeaux $J$, Regoli $D$. Action of anglotensin and analogues on the heart. Can J Physiol Phamacol $1974: 52: 50.60$

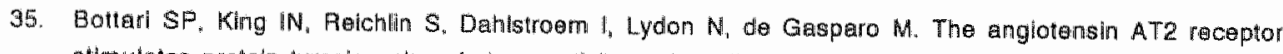
stimuletes protain tyrosine phosphatase activity and mediates inhibition of particulate guanyatte cyclase. Biochem Blophys Bes Cornmun 1992; 183:206-211.

36. Bottarl SP. Taylor 'V, King IN, Bogdal $Y$, Whitebread S, do Gasparo M. Angiotensin II AT2 rocaptors do mot interact with guanime mucleotide binding proteins. Eur w Pharmacol 1981: 207:157-163.

37. Brauneis U, Wassilev PM, Qunn SJ, Willims GH, Tillotson DL. ANG ll blocks patassium currents in zona glomerulosa cells trom rat, bovine and human adrenals. Am J Fhysiol 1991" 260: E772 E779.

36. Brock TA, Alexander AW, Ekstaim LS, Atkinson W.. Angiotensin increases cytosolic frea calcium in culturod vascular smooth muscle cells, hypertension 1985; 7:1105-1109.

39. Browntield MS, Feid IA, Genten D, Genong WF. Ditterential distinction of immunoreactive angiotensin and angiotensin-Conwerting enzyme in rat brain. Neuroscience $982 ; 7: 1759$

40. Brunner HA, Gavras H, Waeber B. Kershaw GA, Turini GA, Vukowich RA, McKinstry VN. Oral angilotensinconverting enzyme inhibitor in longterm treatmenti of hypentensive pattents. Ann hitern Med 1979; $90: 19$. 23.

41. Campbelt DJ. The silte of angiotensin production. J Hypertens 1985: 3:730-737.

42. Campball DJ. Circulating and issue anglotensin systems. J Clin inwast $1987 ; 79: 1.6$. 
49. Cempbell DJ. Hebener JF. Anglotensinogen gene is oxpressed and differemtialily negulatid in multiple tissues of the rat. $J$ Chin huest $1986 ; 78: 39-39$

44. Capasiso JM. Bruno $S$, Cheng $W_{\text {. }}$ L $P$, Rodgers $F$. Darzynkiewicz $Z$. Arversa P. Ventricular loading is coupled with DNA synthesis in adult cardiac myocytes after acute and chronic myociardiall intarton th tats. Circ fes 1992; 7\%:1379-1389.

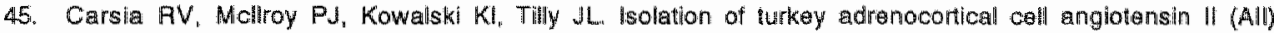
receptor partial cDNA: evidence for a single-copy gene expressed predominamtily the adrental gland. Blochem Biophys Res Commun 1993; 191:1073m1080.

46. Casale PN, Devereux RB, Miner M, Zulio G, Hershteld GA, Plckering TG, Laragh J. Value of ochocardiographic measurement of lett vantricular mass in predicting cardiovascular morbid events in hypertensiwa men. Ann Intem Med 1986; 105:173-178.

47. Chai SY, Allen AM, Adem WR, Mendelsohn FA. Local actions of anglotensin Il: quantitative in vitho autorad: ographic localization of angiotensin I/ receptor binding and amgiotensin converting enzymen target tiss $u$ as. J Cardiovasc Phamacol $7986 ; 8$ (Suppl. 10):S35-S39.

48. Chang $\mathrm{E}_{\text {"Pertman }} \mathrm{A}$. Multiple hormones regulate angiotensinogen messenger ribonucleic acid levels in a rat hepatoma cell line. Endocrinology 1987; 121:513-519.

49. Chang FSL, Lotti WJ. Two distinct angiotensin $\|$ l receptor binding siltes in rat adrenal revealled by mew selective nompeptide ligands. Mol Phamacol 1990; 29:347-351.

50. Chang RSL, Lotti $V$. Angiotensin receptor subypes in rat rabblt and monkey tissues: relative distribution and specles dependency. Lffe Sc 1991; 49:1485-1490.

51. Chen FCM, Printz MP. Chronic estrogen treatment reduces anglotensin II receptors in the anterior pituitary. Endocinolagy 1983, 113:1503-1510.

52. Chernin MI, Candia AF, Stark LL, Aceto JF, Baker KM. Fetal expresision of renin, angiotens hogen, and althopeptin genes in chick heart. Clin Exp Hypertens A 1990; 12:617-629.

53. Childs TJ, Adams MA. Mak AS. Regression of cardac hypertrophy in spontanecusly hypertensive rats by enalapril and the expression of contractile proteins. Hypertension $1990 ; 16: 662-668$.

54. Chimese Cardlac Study Collaborativa Group. Oral captopril wersus placobo among 13634 patierts with suspacted actite myocardial infarction: interim report from the Chinese Cardiac Study (CCS-1). Lancet $1995 ; 345: 686 \cdot 687$.

55. Chiu AT, Herblin WF, McCall DE, Ardacky Fu, Carini DJ. Duncie JV, Pease LJ, Wong PG, Wexler RA, Johns on AL. Timmermans: PMBW. Identification of angliotemsin li receptor subtypes. Biochem Elophys Fos Commun 1989; $165: 196-203$.

56. Chüu AT, MoCall DE, Nguyen TT, Carini DJ, Duncia JV, Herblin WF, Uyeda, RT, Wong PC, Wexler AF, Johnson AL. Timmermans PMEW. Discrimination of angiotansin $\| 1$ receptor subtypes by dithiothretilol. Eur of Phamacol 1989: 170:117-118.

57. Chiu AT, Roscoe WA, McCall DE. Timmermans PB. Anglotensin ll-1 receptors mediate both vasoconstriclor and hypertrophic responses in rat aortic smooth muscle colls. Receptor 1991:1:133-140.

58. Christen $Y$, Waeber $B$, Nussberge J, Porchet $M$, Borland $A M$, Lee PJ, Maggon K, Shum L, Timmermans PB. Brumner HR. Oral administration of DuP, a spectic angiotensin II antegonist, to normal male voluntears: Inhibition of pressor response to exogeneous anglotensin I and II. Circwation 1991; 83:1333-1342.

59. Clark KL, Fobertson MJ. Drew JMH. Effects of the non-peptida angiotensin recaptor antagonlst DUP 753, on basal renal function ard on the renal effects of anglotensin 11 in the amaesthetised dog. Br I Pharmacol $1991 ; 104: 78$.

60. Cogan $M G$, Liu $F Y$, Wong $P C_{n}$ Timmermans $\mathrm{PB}$. Comparison of inhibitory potency by nonpeplide angioten. $\sin 11$ receptor antagonists PD123177 and DuP753 on proximal nephron and renal transpont. J Phanmecol Exp Ther 1991; 259:687-691. 
61. Corra FMA, Guhaume SS. Sitavedra JM. Comparatime quantification of rat brain and pituitain angiotenstri-conventing enzyme with autoradiographic and enzymatic methods. Brain Res $1991 ; 545: 215$. 222 .

62. Crane JK, Campantle CP, Garrison JC. The hepatic angiotensin II receptor. Eftect of guanine nucleotides and interaction with cyclic AMP production. J Blol Chem 1982; 257:4959-4965.

63. Crawtord DC, Chobanian AV, Brecher P. Angiotensin II induces fibronectin expression associated with cardac tibrosis in the rat. Cire Aes 1994: 74:727.739.

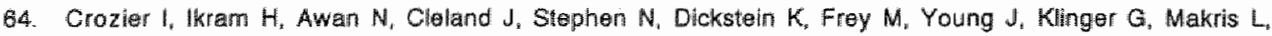
Puchnsk E, lor the Losartan Hemodynamle Study Group. Losartan in heart fallure. Hemodynamic effects and tolerability. Chculation 1955; $91: 091-697$.

85. Daemen Mu, Lombardi DM, Bosman FT, Schwartz SM. Angiotensin il induces smooth muscle cell proliferation in the normal and injured rat arterlal wall. Circ Res 1991; 68:450 -456.

66. Dahlof B. Factors inwovedin the pathogenesis of hypertensive cardlowascular hypertrophy. A review. Drugs 1998; 35 (Suppl. 5):6-28

67. Dahlot 8. The importance of the reninanglotensin system in reversall of left ventricular hypertrophy. Hypertens Suppr 1993: 11:\$29-S35.

68. Dehloff $B$, Hansson L. Regression of left ventricular hypertrophy in previlously untreated essential hyperten. sion: different effects of enalapili and hydrochlorothiazide. s Hypentens 1992; 10:1513-1524.

69. Dahlof B, Pennert $K_{4}$ Hensson L. Raversal of left ventricular hypertrophy in hypentensive patients: a metaanalysis of 109 trialment siudies. Am J Hyperters 1992; 5:95*110.

70. Denilov SM, Chumachenko PV, Andreeva YV, Printseva OY, Lacis RV. Angiotensin converting enzyme expression in the inflammation zone of human myocardial infatction and rat model of skin injury. H Hypertens Suppl 1993:11 (Suppl. 5):S232-S233.

71. Danser AHJ, Kats JP, Admiraed PJl, Derkx FHM, Lamers لMJ "Verdouw PD, Saxena PR, Schalekamp MADH. Cardlac renin and anglatensins. Uptake from plasma versus in situ synthesis. Hypertension 1994: $24: 37-48$

72. Dargle HJ. Interrelation of electrolytes and renin-angiotensin system in congestive heart failure. Arm $\mathrm{d}$ Cardial 1990; 65;28E-32E.

73. Davis MH, Pleringer J. Regulation of dipeptidyl aminopeptidase I and angiotensin converting enzyme activities in cultured murine brain cells by cortisol and thyroid hormone. J Neurochem $1987 ; 48: 447.454 .4$.

74. Dompsey PJ, McCallum ZT, Kant KM, Cooper T. Direct myocardial eftects of angiotensin II. Am of Physiol $1971 ; 220: 477 \times 481$.

75. Deschepper CF. Mellon SH, Cumin Faxter JD, Ganong WF. Analysis by lmmunocytochemistry and in situr hybridizatlon of renin and its mANA in kidney, testis, adrenal, and piluetary of the rat. Proc Nat' Acad Sici U 5 A 1986; $83: 7552.7556$.

76. Devereux RB, Pickering TG, Cody RJ, Laragh JH. Pelation of renin-anglotensin system activity to latt ventricular hypentrophy and function in experimental and human hypertensiton. J C/n lowest 1987; 3:87-103.

77. Doi Y, Atarashi K, Franco-Saenz A, Mulow P. Adrenal renin: a possible regulator of aldosterone production. Ciln Exp Hypertens A 1983; 5:1119-1126.

78. Dosemed A, Dhallan RS, Cohen NM. Lederen WJ, Rogers TB. Phorbol ester increases calcium current and sirmulates the ettects of anglotensin II an cultured neonatal rat healt myocytes. Circ Fes 198: 62:347.357.

79. Dostal DE, Baker KM. Anglotensin Il stimulation of left ventricular hypertrophy in adult rat heart. Mediation by the AT1 receptor. Am J Hypertens 1992; 5:276-280.

80. Dostal DE. Rothblum KN, Chemin ML, Cooper GR, Baker KM. Intracardlac detection all anglotensinagen and renin: a localized renin-anglotensin system in neonatal rat heart. Am J Physiol 1992; 263:C.838-C850.

81. Dostal DE, Rothblum KN, Conrad KM, Cooper GR, Baker KM. Detectlon of anglotensin I and II in cultured rat cardiac myocytes and fibroblasts. Am J Physiol 1992: 263:C85: C863. 
82. Douglas JG. Angiotensin receptor subtypes of the kidney cortex. Am J Physiol 1987; 253:F2.FF.

Q3. Douglas JG, Romero M: Hopter $U$. Signaling mechanisms coupled to the anglotensin receptor of proxinal twbutar eplthellum. Koney Int Suppt 1990; 30:543-S47.

84. Dudley DT. Hubbell SE, Summerfelt RM. Characterization of angtotensin II (AT2) binding sites in PBTs cells. Mol Phamacol 1991; 40:360.367.

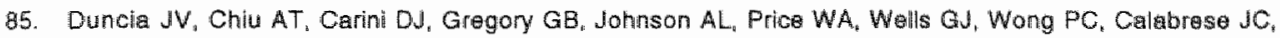
Timmermans PB. The discovery of potent nonpeptide angiotensin tl teceptor antegonists: a new clasis of potent antihypertensives. J Med Chem 1990; $33.1312-1329$.

B6. Dzau $\mathrm{V}$. Implications of local angiotensin production in cardiovascular phys lology and phermacology. Am $J$ Cardio 1987; $59: 59 \mathrm{~A}$

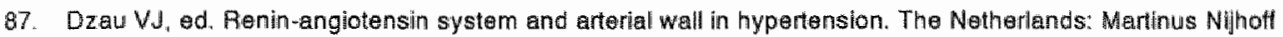
Publishers, 1987.

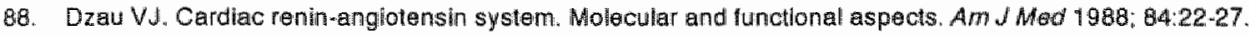

89. Dzau V.J. Circulating versus local renin-anglotensin system in cardiovascular homeostasis, Chrculation $1988: 77$ (Supp: 1$): 1-4-1-13$.

90. Dzau VJ. Muttiple pathways of angiotensin production in the blood vessel wall: vidence, possibilities and hypotheses. J'Hypertens $1989 ; 7: 933-936$.

91. Dzau VJ. Angiotensin converting enzyme inhibitors and the cardiovascular system. I Hypertens 1992 . 10 (Suppl. 3):53-510.

92. Dzau VJ. Vascular renin-angiotensin system and wascular protection. J Cardiowasc Phamacof $1993 ; 22$ (Suppl. 5).S1-S9.

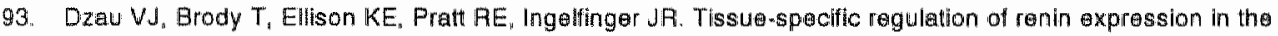
mouse. Hyportension 1987; 9 (Pt 2):1l36-1141.

94. Dzau VI, Ellison KE, Brady T, Ingeltinger J, Pratt RE. A comparative study of the distributions of renim and angiatensinogen messenger ribonucleic acids in rat and mouse tissues. Endocrinology 1987; 120:23342338.

95. Dzau WJ, Pratt RE, eds. Fenin-angiotensin system: biology, physiology and pharmacology, New York: Rawen Press, 1986.

96. Dzau VJ, Re RN. Exidence fol the existence of remin in the heart. Circulation 1987: 75:1134.1136.

97. Dzau VJ, Sands K. Regulation of brain renin: eviognce for an independent brain renin. Clin SC 1982" 63.163 s.

98. Edwards RM. Alyair N. Angiatenisin 18 receptor subtypes in the kidney. I Am Soc Nephrol 1993: 3:1643. 1652 .

99. Ehlers MP. Riordam JF. Angiotensin-converting enzyme: new concepts concerming its blological role. Biochemistry 1989; 28:5311-5318.

100. Elchstaedt $H$, Dame $O$, Langer $M$, Cordes $M$, Schubert $C$, Fallx Fi, Schmutzler H. Regression of lent" ventricular hypertrophy under ramipril treatment investigated by nuclear magnatic rasonance imaging. I Cardiovasc Pharmacol 1989; 13 (Silppl. 3):S75-S80.

101. Ellison KE, Ingellinger JF, Pivor M, Dzau VJ. Androgen regulation of rat renal angiotentimogen messenger RHA expression. J Clin invest 1989; 83:1941-1945.

102. Erdos EG. Angülensin I converting enzyme and the chenges in our concepte through the years. Lewis K. Datil memorial lecture. Hypertension 1990; 16:363.370.

103. Erdos EG, Skidgel RA. The anglotensin -converting anzyme. Lab lnwest 1987: 56:345-348.

104. Ent G. Gaudron P, Eilles $C$, Kochsiek K. Serial changes in lett venticular size after acute myocardial infarction. Am J Candiol 1991; 68:1460-120D.

105. Fabris $B$, Jackson $B$. Kohzuki M, Perich $\mathrm{A}$, Johnston Cl. Increased cardiac anglotonsin-converting enzyme in rats with chronic heart failure. Clin Exp Pharmacol Physiol 1990; $17: 309 \times 314$. 
106. Fermandez LA, Cagride WJ, Twikler J. Renin-angiotensin and development of colletteral circulation after renal ischemia. Am J Physiol 1982; 243:H869.H875.

107. Ferrandez LA. Twickler N. Mead A. Neovascularization produced by angiotensin II. I Lab Clin Med 1985; 105:1.414.145.

108. Fletd LJ, MCGowan RA, Dickinson DP, Gross KW. Tissue and gene specilicity of movse remin expression Hypertension 1984; 6:597-603.

103. Fishbein Maclean D. Maroko P. The histopathologic ewolution of myocardial infarction. Chest 1978:843849 .

110. Fitzpatrick MA, Fademaker MT. Espiner EA. Acute ffects of the angiotensin lll antagonist. DuP 753, in heart tallure. J Am Coll Cardiof 1992; 19:14BA.

111. Fouad FM "Tarazi RC. Bravo EL. Cardlac and haemodynamic effects of enalapril. I Hypertens Suppl 1983; $1: 135-142$

142. Friadlarid J, Setton $C$, Silwerstein E. Angliotensin converting enzyme: Induction by sterolos in rabbit alveoler macrophages in culture. Science 1977; 197:64-65.

113. Fromlich ED. Aegression of cardiac hypertrophy and lett ventificular pumping ability postregression. $J$ Cardiovase Pharmacol 1991; 17 (Suppl. 2):S81-S66.

114. Frohlich $E D$, lwata $T$, Sasaki $O$. Clinical and physiologic significance of local tissuse renin-amgiotensin systoms. Am J Med 1989; 87:19S.23S.

115. Fyhrquis $\mathrm{F}$, Forslund T, Tikkanen I. Gronhagen ifiska $\mathrm{C}$. Induction of angiotensin I converting enzyme in rat Iung with captopril (SQ 14225). Eur J Pharmacol 1980; 67: 124-128.

116. Fyhrquist F, Gronhagen-Aiska $C$, Mortling L, Forsiund $T$, Tikkanen I. Fegulation of angiotensin converting enzirne, J Hypertens Suppl 1983; 1:25-30.

117. Ganten D, Fuxe K, Philips M1., Marn JFE, Ganten U. The brain isorenin-angiotensin system: biochemistry, localization and possible role in drinking and blood pressure regulation. Now York: Raven Press, 1984.

118. Ganten $D ; H$, Hormann $K$, Unger $T$. Lang $R E$. The tissue renin-angiotensin systems: focus on brain angiotensin, adrenal gland and artertal wall. Clin Exp Hypertens $A 1983 ; 5: 1099-1118$.

119. Garcia-Sainz JA. Anglotensin II receptors: one type coupled to two signal of receptor subtypes? Trends Pharmacol Sci 1987 ; $8: 48-49$.

120. Gibbons GH, Pratt $A E$, Dzau VJ. Vascular smooth muscle cell hypertrophy vs. hyparplasia. Autocrine Transtorming Growth Factor-beta1 expression determines growth response to angiotensin II. $J$ Clin $/ \mathrm{nw}$ st 1992; 90:456-481.

121. Gibson AE, Thorpe HH, Cartwright ME, Frank JD, Schorn TW, Bunting PB, Stegl PK. Anglotensin II recoptor subtypes it rentil cortex of rats and thesus monkeys. Am I Physio/ 1991; 261:F512 F518.

122. Gohlke P. Linz W. Schalkens BA, Kuwer I, Bartenbach S, Sichnell A, Unger T. Anglotensin-converting anzyme inhibiltion improwes cardac function. Role of bradykinin. Hypentension 1994; 23:411-418.

123. Gohlke $P$. Stoll M. Lamberty $V$. Mattfeld $T$. Mall $G$, van-Even $P$, Martorana $P$, Unger $T$. Caridac and vascular affects of chromic anglotensir converting enzyme inhibition at subartithypertensive doses. I Hypertens Sispol 1992; 10:5141.S144.

124. Goodfrend TL. Angiotensins. A family that grows from whin. Hypertension $1991 ; 17: 139-140$.

125. Grady EF. Sech LA, Griffin CA. Schambelan M, Kalinyek JE. Expression of AT2 receptors in the developing rat Hetus. Clin hnves" 1991; 88:921-933.

126. Grajek $S$, Lesiak M, Pyda M, Zaįac M, Paradowski S, Kaczmarek E. Hypertrophy or hyparplasia in cardiac muscle. Post mortem human morphometric study. Eur Meart $J \Downarrow 993 ; 14: 40-47$.

127. Griendling KK, Rittenhouse SE, Brock TA, Ekstein LS, Gimbrono MA, Alexander RW. Sustained diacylgiyceral formation from inositol phospholipids in angiotensim lllstimulated wasciflar smooth muscle cells. $J$ Bjof Cham 1986; 261:5901.5906.

128. Grossman W. Cardiac hypertrophy. Useful adaptation or pathologic process? Am J Med 1980; 69:576-584. 
129. Gruppo ttaliano per to Studio della Soprawiwenza nellinfarto miocardico. GISSI-3: aftac of lisinopril and transtermal glycery trinitrate singly and together on 6 -wesk mortality and wentricular function after acute myocardial infarction. Lance $199.4: 343: 1115-1122$

130. Gunther S. Characterization of anglotensin II receptor subtypes in ral liver. J Biol Cham 1984;250:7622 7629 .

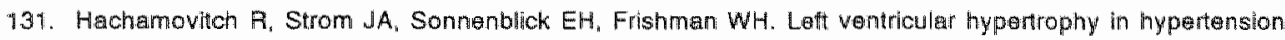
and the effects of antihypertensive drug therapy, CurT Prob/ Cardiol 1988; 13:369-422.

132. Hackenthal $E$, Hackenthal $R$, Higentaldt U. Isorenin, pseudorenin, cathepsin $D$ and renim: a comparative study of angiotensin-forming enzymas. Biochim Biophys Acta 1978.522.574-588.

133. Hackenthal E, Paul M. Ganten D. Taugner R. Morphology, physiology, and molecular biology of renin secretion. Physiof Rev 1990; 70:1067-1116.

134. Halnoczky G, Csordas G. Bago A, Chiu AT, Spat AT. Angiotensin ll axents its effect on aldosterone produc tion and potassium permeability through receptor subrype ATt in rat adrenal glomerulosa cells. Biochem Pharmacol 1992; 43:1009*1012.

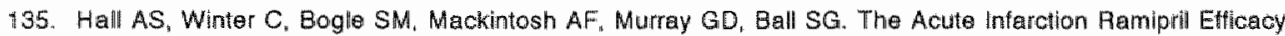
(AIRE) Study: rationale, design, arganization, and outcome delinitions. I Candiavasc Phamacol 1991; 18 (Suppl, 2):S105-S109.

136. Hall JE, Mizelle $\mathrm{HL}$, Woads $\mathrm{LL}$. The renin-anglotensim system and long-term regulation of enterlal pressure. J Hypentens $1986 ; 4387-397$

137. Harper $J_{1}$ Harper $E$, Covell JW. Collagen characterization in volume-overload-and pressurre-overloadinduced cardiac hypertrophy in mintpigs. Am J Physiol 1993; 265:H434-H438.

138. Hausdorf WP. Sekura RD. Aguilera G, Catt KJ. Control of aldosterone production by anglotensin II is medlated by two guanine nucleatlde regulatory prateins. Endocrinology $1987 ; 120: 1668-1678$.

139. Herrmann $\mathrm{HC}_{\mathrm{x}}$ Dzau $\mathrm{VJ}$. The feedback regulation of angiotensinagen productlon. Circ Aas $1983 ; 52.328$,

140. Hermann HC, Morris BJ, Reid IA. Effeet of anglotensin II and sodium depletion on anglotensinogen production. Am J Physiol 1980; 238:E145-E149.

141. Hilgenfeldt $U$, Hackenthal E, Separation and characterization of two difterent species of rat angiotentsin. ogen. Biochim Biophys Acia 1982; $708: 335-342$.

142. Hirsch AT, Pinto $Y M$, Schunkert $H$, Dzau WJ. Potential role of the tissue renir-angiotensin system in the pathophysiology of congestive heart failure. Am J Cardiol 1990; 66:220-32D.

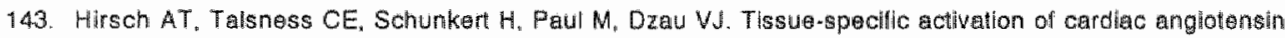
converting enzyme in experimental hear failure. Circ Aes 1991; $69: 475-482$

144. Hogarty DC "Phillips MI. Vasopressin rellease by contral anglotensin II is mediatod thiough an anglotansin yype. 1 receptor and the drinking response is mediated by both AT-1 and AT-2 recoptors. Soc Nawr $5 \mathrm{w}$ $1991 ; 17: 41188$

1.45. Holubarsch $C$, Hasentusis $G$. Schmidt-Schweda $S$, Knor $A$, Pleske B, Fuf $T$, Fasol $A$, Just H. Angiotinsin 1 and Il exert positive inotropic efiects in airial but not in wentilicular human myocardilum. An in vituo study under physlological experimental conditions. Circulation 1993; 88:1228-1237.

1,46. Hoyer J, Popp 月, Meyer J. Galla HJ, Gogeliein H. Anglotensin II, vasopressin and GTPIglamma-S] inhibit

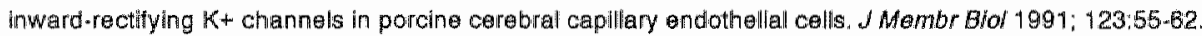

147. Hutchins $\mathrm{GM}$, Bulky BH. Infarct expension wersus extension: two difterent complications of ecute myocardlal infarction. Am J Cardiol 1978; 41:1127-1132.

148. Ideishi $M$, Sasaguri M, Ikeda M, Arakawa K. Substratemdependent anglotensin Il formation in the peripherai cliculation. Life Soj 1990; $46,335 \cdot 341$

148. Inagami T. Fenin in the brair and neuroblastoma celis: ar endogenous and intracellular system. Neuroen. docrinology $1982 ; 34: 475-483$. 


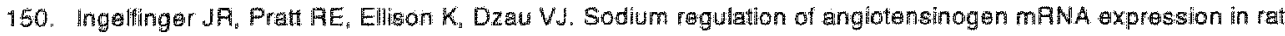
kidney cortex and medulla. J Chin Invest 1986; 78.1311-1315.

151. Ingelfinger JP, Zuo WM. Fon EA, Ellison KE. Dzew VH. In siút hybridization widence for angiotensinogen

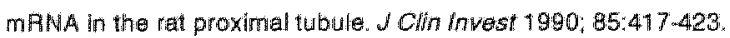

152. ISIS-4 (Fourth linternational study of Interct Survival) Colleboratiwe Group. ISIS-4: a randomized factorial trial asesesing exty oral captopril, orel mononitrate, and intravenous magnesium sulphate in 58050 pattents whith suspected acule myocardial intarction. Lancet 1995: 345:669-685.

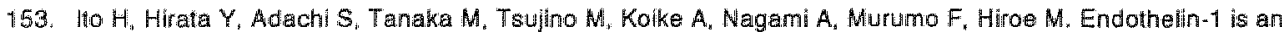
autocine/parachine factor in the mechanism of angiotensin llinduced hypartrophy in cultured rat cardlomyocytag. J Chin hivest $1993 ; 92: 398-403$.

154. Iwai N. Inagami T. Identitication of wo subtypes in the rat type I anglotensin II receptor. FEBS Lert 1992; $298: 257-260$.

155. Wai $N_{3}$ Inggami T. Quanttetive analysis of renin gene expression in extrarenal tissues by polymerase chain reaction fothothod. Jypentens $1992 ; 10: 717.724$.

156. Wwao H, Nakamura A, Fukul KK, Kmura S, Tamaki T, Abe Y. Endogenous angiotensin II regulates hepatic anglotensinogen production. Lifo Sci $1990 ; 47: 2343 \cdot 2349$.

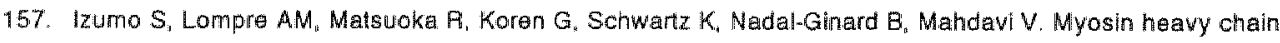
messangar RNA and protein isoform transitions during cardiac hypertrophy interaction between hemadynamic and thyroid hormone induced signals. I Chin Invest' 1987; 79:970-977.

158. Izumo $S_{3}$ Nedal-Ginard $B$, Mahdawi $W$. Protooncogene induction and reprogrammang of cardiac gene expression produced by pressure overload. Proc Nall Aicad Sci U S A 1988; 85:339-343.

159. Jackson $B$, wohnston Cl. Anglotensin converting enzyme during acute and chronic enelapril therapy in ossential hypertension. Exp Pharmecol Physiol 1984: 11:355-359.

160. Jackson TR, Blair LA, Marshatl $J$, Goedert M, Hanley MR. The mas oncogene encodes: an angiotensin receptor. Nature 1986;335:437.440.

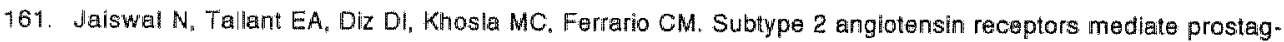
landin symesis in human astrocytes. Hypertension 1991; 17:11115 1120 .

162. Janiak $P$, Libert $O$, Vilaine JP. Role of the renin-angtotensin system in neointima formation after injury in rabbits. Hypertension 1994: 24:671-678.

163. Jard S, Cantau B, Jakobs $\mathrm{KH}$. Anglatensin II and alpha-adrenergic agonists inhibit rat liver adenylate cyciese. J Blol Cham 1981; 256:2603-2606

164. Jn H, Oparil S. Anm HS, Yang $R$, Jackson PM. Hypoxia-induced inhibition of anglotensin converting enzyme actitity: Aola in vascular ragulation. J Appl Physiof 1987; 63:1012-1018.

165. Johnson MC, Agilleta G. Angiotensin-ll receptor subtypes and coupling to signaling systems in cultured fetigl libroblastis. Endocnindogy 1991; 129;1266-1274.

166. Johnston $\mathrm{Cl}$. Biochemistry and phamacology of the reninnanglotensin system. Drugs 1990; 39 (Suppl. 1):21.31.

167. Kalda $\Upsilon$. Komuro I. Yazakil Y. Increased proteiry synthesis and myosin usoform change in cultured cardiocy. tes by loading. (Abstract). Circulation 1988; 78:11-242.

168. Kakar SS, Fliel KK, Neill JD. Difterenthat expression of anglotensin ll receptor subtype mRNAs (AT.1 A and AT.1B) in the brain. Blocham Blophys Res Commun 1992; 185:688-692.

169. Kakar SS, Sellers JC, Devor DC, Musgrove LC, Neill JD. Angiotensin ll type-1 receptor subtype cDNAs: differential tissue expression and hormonal regulation. Blochem Biophys Res Commun 1992; 183:1090. 1096.

170. Kambayashi $Y$, Bardhan $S$, Takahashi K, Tsuzuki $S$, Inui H, Hamakubo $T$, Inagami T. Malecullar cloning of a nowel angiotensin il ireceptor isotorm inwolved in phosphotyrosine phosphatase inhibition. I Biol Cham $1993,266: 24543-24546$ 
17. Kannel WB, Gordon T, Otfut D. Left ventricular mypertopihy by electracardlogrem: prevalance, incidence and mortally in the Firaminghan Heart Study. Ann Intom Med $1969 ; 7189-105$.

172. Katz. A.M. Cardiomyopathy of overload. A major determinant of prognosis in congestive heant fallure. Newt Eng w Mad 1990; 322:100-110

173. Khairatah PA, Robertson AL, Davila D. Efects of angiotensin II on DNA, ANA and protein symthesis. Hypertension 1972:212-220.

174. Khanum A. Dufau ML. Angtotensin ll receptors and inhibitory actions in Leydig cels, I Biol Chom 1988; 263:5070-5074.

175. Khayyall M, MacGiregor J. Brown JJ, Lewer AF, Robertson Jis. Mhorease of plasme ranin-substrate concentration after infusion of angiotensin in the rat. Clin Sci 1973: 44:87.90.

176. Kimura $B_{1}$ Sumners $C$. Philips MI. Changes in skin angiotensin II receptors in rats during wound healing. Blochem Blophys Fos Commun 1992; 187:1083-1090.

177. Kimura $B$. Sumners $C$, Phillips ML. Changes in skin angiotensin $1 \mid$ receptors in rats durlng wound healing. Biochem Biophys Res Commun 1992; 187:1083-1090.

178. King SJ, Bocyse FM. Lin PH. Traylor M, Narkates AJ, Oparll S. Hypoxia stimulates endothelial call angiotensin-converting enzyme antigen synthesis. Am J Physiol 1989; 256:C1231-C1238.

179. Knowiton KU, Michel MC, lani M, Shubeita HE, lshihara K, Brown JH, Chien KA. The alpha $1 \mathrm{~A}$-adrenergic receptor subtype mediates biachemical molecular, and morphologic teatures of culliured myocardial cell hypertrophy. J Erol Chem 1993; 268:15374-15380.

180. Kobayashi M. Furukawa $Y$, Chiba. S. Positive chronotrople and inotropic effects of angiotensin II in the dag heart. Eur J Pharmacol 1978; 50:17-25.

181. Koch-Wesser J. Myocardial actions of anglotensin. Chr Res 1964; 14:337-344.

182. Konishi $\mathrm{H}$, Kuroda $S$, Inade $Y$, Fujisewa $Y$. Novel subtype of human angiotensin II typo 1 receptor: CDNA cloning and expressiom. Biochem Blophys Res Commun 1994; 199:467-474.

183. ven Krimpen $C_{n}$ Smits JFM, Cleutiens JPM. DNA synthesis in the non-intarcted cardlac interstitum is increased mfter lett cononary artery liglation in the rat: effects of captopril. W Mol Cell Cardiol 1991: 23:12451253.

184. Kromer EP. Riegger GA. Effects of long-term angiotensin converting anzyme inhibition on myocardieal hypentrophy in experimental aortic stenosis un the rat. Am J Cardiol 1988; 62,161-163.

185. Kromer EP. Schunkert H. Ackemann B. Eftects of angiotensin lli-receptor antagonism on pressure induced left ventricular hypertrophy (abstract). W Hypertens 1992; 10:\$252

196. Kuzinga MC, Cleutjens JPM, Smits JFM, Dwmen MJAP. Griftonia simplificolia I (GSI): sultubla rat cardiac microvascular marker on parattin smbedded tissue. J Mol Coll Cardiol 1992; 24 (Suppil. V):S57.

187. Kunapul SP, Kumar Au Molecular cloming of human angiotensinogen cDNA and avidence for tha pressonca of its mPNA in rall heart. Circ Ales 1987:60:786-790.

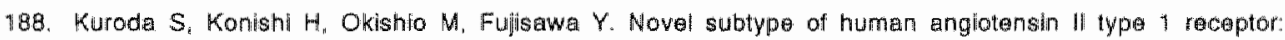
analysis of signal transouction mechanism in transfected Chinese hamster ovary cells. Blochem Bhophys Res Commun 1994: 199:475-481.

189. Lassague B. Alexander RW, Clark M. Akers M, Griendling KK. Phosphatidylchollne is major source of phosphatidic acid and diacylglycerol in angiotensin $11-$ stimulated vascular simoolh-muscle cells. Bhochem $J$ $1993: 292: 509 \cdot 517$

190. Lassegue B. Alexander BW, Clark M, Grianding KK. Angloterisin If-induced phophatidylcholine thydrolysis in cultured wascular smooth-muscle cells. Biochem / 1991;276:19-25.

191. Lassegue B. Griendling KK, Muphy TH, et al. Regulation of angiotensin ll receptor exprossion in wascular smooth musclle celis, FASEB I 1992; 6:A1859. 


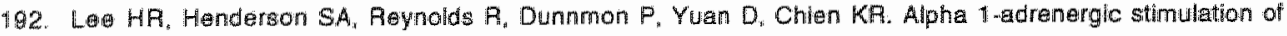
cardiac gene tranecription in neonatal rat myocardial cells. Effects on myosin light chain-2 gene expression. Hior Chem 1988: 263:7352-7358.

193. Leenen FHH. Smith DL, Ungler WP. Topical minoxidits cardiac effects in baid man. Br J Cin Phamacol $1988: 26: 481-485$

194. Le.Nobie FA, Schreurs NH, wain.Straaten HW, Slaaf DW, Smits JF, Rogg H, Struijker-Boudier HA. Evidence tor a novel anglotensin I recoptor involved in angiogenesis in chick embryo chorioatlantotc membarane. Am I Phystol 1993; 264: F460-R465.

195. Leung KH. Rowcov WA, Smith RD, Timmermans PB, Chit AT. Characterization of biochemical responses of anglotensin II (AT2) binding sites in the rat pheochromocytoma PC12W cells. Eur J Pharmacol 1992: $227: 63-70$.

496. Levy D, Garison FJ, Sawage DD, Kanel WB, Caastelli WP. Left wentricular mass and incidence of coronary heart disease in an elderly cohort the Framingham Heart Study. Ann Inten Med 1989; 110:101-107.

197. LI $C$. Prakash $O_{1}$. Pe PN. Attered regulation of anglotensinogen gene expression in the left ventricle oft the inypentemsive reat. Circulation 9 989; $80: 111450$.

198. Liebson PA, Savage DD. Echocardiography in hypertension: a review. Il. Echocardographic studies of the ellects of anthypertensive agents on left ventricular wall mass and function. Echocardiography 1987: $4: 215-249$

199. Lind AW, Swanson LW, Ganten D. Organization of angiotensim II Immunoreactive celis and fibers in the rat central nervous system. An imminohistachemical study. Neuroendocrinology $1985 ; 40: 2-24$.

200. Lindpaintrer $K$, Jin MW, Niedermaier $N$, Whe lim Mi, Ganten D. Cardiac anglotensinogen and its local activation in the isolated perfused beating heart. Circ Res $1990,67: 564-573$.

201. Lindpaintmer $K, \operatorname{Jin} M$, Wilhelm MJ. Suzuki F, Linz W. Scholkens BA, Ganten D. Intracardiac generation of angiotensin and its physiologic rolle. Circulation 1988; 77:118-123.

202. Lindpaintner $K_{,}$Lu W, Naidarmaler $N_{1}$, Schietfer $B$, Just $H$, Ganten $D$, Drexler $H$. Selective activation of cardlac amglotensinogen geme expression in post-infarction wentricular remodeling in the rat. a Mol Cell Cardiol 1993; $25: 133-143$.

203. Lindpaintner $K$, Suzuki $F$, Munakami $K$, Ganten D. Renin gene expression: a genetic marker associated with primary hypertension. Circulation 1987: $76: 345$.

204. Lindpaintner $K$, Wilhelm MJ, Jin $M$, Unger $T$, Lang $A E$, Scholkens $B A_{i}$ Ganten $D$. Tissue renin-angiotensin systems: focus on the heart. Hyperters Suppt 1987; 5:533-\$38.

205. Linz W. Henning $A$, Schollkns BA. Hole of angiotensin 11 receptor antagonism and convering enzyme inthbition in the progression and regression of cardiac hypertrophy in rats. J Hypertens Supp: 1991: 9:S400. 8401.

206. Linz W, Schokens BA. A specifle B2-biradykin receptor antagonist HOE 140 abolishes the antihypertrop. hic effect af ramipril. Br. Pharmacol 1992; 105:771-772.

207. Linz W. Scholkens BA. Ganten D. Conventing enzyme inhiblitor specifically prevents the development and induces ragression of cardiac hypertrophy in rats. Clin Exp Hypertens A 1989; 11:1325-1350.

208. Linz W, Scholkens 8A, Hain WF. Beneficlal efteats of the converting enzyme ramipril in ischemic hearts. $J$ Hyperters Supph 198:6: B:S91-S99.

209. Linzbach AJ, Heart failure from the point of view of quantitative enatomy. Am J Cardial 1960; 5:370-382

210. Long CS. Ordaht CP. Simpsion PC. Alpha 1-adrenergic receptor stimulation of sarcomeric actin isogeme transcription in hypentrophy of cultured rat heart muscle cells. 1 Clin thvest 1989; 83:1078.1082.

211. Lynch CU, Prpic V, Blackmore PF, Exon JH. Effect of isletwactivating pertussis toxin on the binding characteristics of Ga2t-mobillzing harmones and on agonist activation of phosphorylase in hepatocytes. Mol Pharmacol 1986; 29:196-203. 


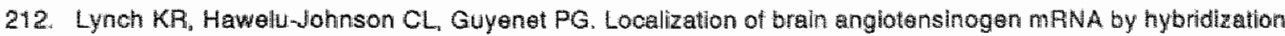
histochemistry, Brain Fes 1987; 388:149-158.

213. Lynch KR, Simnad VI, Ben-Ari ET, Garrison WC. Lacalization of preangioteneinogen messengor RNA sequences th the rat brain. Hypertension $1986 ; 8: 540.543$.

214. Makino $N$. Matsui $H_{8}$ Masutomo $K_{z}$ Hate $T$, Yanaga $T$. Effect of angiolensin converting enzyme inhibitor on regression in cardiac hypertrophy. Mol Cell Ejochen $1993 ; 119: 23-28$.

215. Mall $G$. Zimmer $G$. Baden $S$, Watteldt $T$. Capillary neoformation in the rat heart.Stereological studies on papillary muscles in hypentrophy and physiologitc growth. Basic Res Cardiol 1990; $85.531-540$.

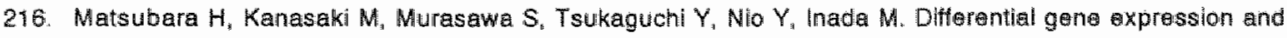
reguletion of anglotensin II receptor subtypes in rat cardiac tibroblasts and cardiomyocyles in culture. $J$ Clin Inves! 1994; $93: 1592-1601$.

217. Mauzy CA, Hwang O. Eglotf AM, Wu LH, Chung FZ. Cloning, expression, and characterization of gene ancoding the human angiotensin II type 1A receptor. Biochem Brophys Res Commun 1992 186:277-284.

218. MCKay RG. Pfeffer MA, Pastemak RC, Markis JE, Come PC, Nakao S, Alderman JD, Ferguson JW, Sallain RD. Grossman W. Left ventricular remodeling after myocardial infarction: a corollary to intarct axpanstom. Circulation 1986: 74:693-702.

219. Meggs LG, Coupet J. Huang H. Cheng W, Li P, Capasso JM, Homcy CJ, Anversa P. Riegulation of angilotensin 11 receptors on ventricular myocytes ather myocardial hintarction in rats Girc Res $1993 ; 72: 11.49-1162$.

220. Melby JC "The renin-angiotensin-aldosterone compliox. Am J Med 1986; 81:8-12.

221. Michel JB, Lattion AL, Selzmann JL, Cerol ML, Phillppe M, Camilleri JP, Carvol P. Hormonal and cardiao effects of conwerting enzyme inhibition hn rat myocardlial intarction. Circ Res 1988; 62:641.650.

222. Millan MA, Jacobowitz DM, Aguilera $G$, Catt Ku. Differential distribution of ATI and AT2 angiotensin II receptor subtypes in the ral brain during development. Froc Nat AGad Sci US A 1991; 88:11440-11444,

223. Miller.Wing AV, Hanesworth JM, Sardinie MF, Hall KL, Wright WW, Speth RC, Grove KL. Hearding JW. Central angiotensin IV binding sites; distribution and specifty in guinea pilg brain. J Pharmacol Exp Ther $1993 ; 266: 1718 \cdot 1726$.

224. Mirsky 1, ed. Elastic properties of the myocardium a gluantitative approach with physlological and clinical applications, seict 2 ed. W. I. Baltimore: Williams and Wikins, 1979.

225. Mizuno $K$, Tanil M, Hashimoto $S$, Nimura $S_{i}$ Sanada $H$, Watanabe $H$, Ohtsuki M, Fukuchi $S$. Elfects of losartan, a nompeptide angiotensin II receptor antegonist, on cardiac hypertrophy and the tissue angiotensin Il content in sportaneausly hypertensiwe rals. Life Sci 1992; 51:367-374.

226. Morton $\mathrm{J} J$, Beattie EC. MacPherson F. Anglotensin II receptor antagonist losertan has peristent ettects on blood pressure in the young spontaneously hypertensive rat: Lack of relation to vascular structure. $J$ Vasc Pos 1992; 29:264-269.

227. Hukoyama $M$, Nakajima $M$. Horluchi M. Sasamura H. Pratt RE, Dzau VJ. Expression cloning of typo 2 anglotensim ll receptor reveals a unique class of seven-transmembrane recoptors. I Blol Chom 1993 ; 268:24539-245:42

228. Murphy TJ, Alexander RW. Grtendling KK, Riunge MS, Bernsteln KE. Isolation of a cDNA oncoding the vascular type-1 angiotensin II receptor. Nature 1991:351:233-236.

229. Naftulan AJ Oparil S. Inhibition of renin release from rat kidney slices by the anglotensims. Am J Physiol 1978 ; 235:F62. F68.

230. Naftilan AJ, Pratt RE. Dzau VJ Induction of pletellet-dertved growth factor A-chain and camyc gene expres. sions by angiotensin II in cultured rat vasicular smooth muscle cells. J CNin Invest 1989; 83:1419-1424.

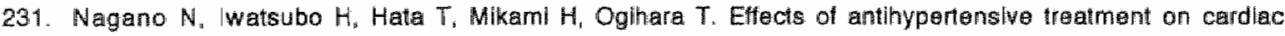
hypertrophy and cardiac lunction in elderly hypenensive pathents. J Cardiovasc Phamaco/ 1981: 17 (Suppl. 2j):S163-S165. 
232. Nahmod VE, Balda MS, Pirola CJ. Finkelman $S$, Gejman PV, Cardinali DP. Circadian thythm and neural regulation of rat pineal angiotensin convertirg enzyme. Brain Ress 1982; 236:216-220.

233. Nakajima M. Mukoyama M. Prat FE, Horiuchi M. Dzau VJ. Cloning of CDNA and analysis of the gene for mouse angiotensin If type 2 recaptor. Blachem Biophys Res Commun 1993; 197:393-399.

234. Nakamura $N$, Burt DW. Paul $M$. Dzau V.l. Negative control elements and CAMP responsive sequences in the tissue-specific expression of mouse renin genes. Proc Nat Acad Sci U S A 1989; 86:56-59.

235. Narusw $M$, Takil $Y$, inagami $T$. Renin exists in high concentrations in the adrenal gland of the rat. Biomed Aov $1981: 2: 583$.

236. Nasjletti A, Masson GMC. Stimulation of angiotensinogen formation by renin and angiotensin. Proc Soc Exp Biol Mad 1973: 142:307-310.

237. Nouss $M$. Regitz-Zagrosek $V$. Hildebrandt $A$, Fleck $E$. Human cardiac fibroblasts axpress an angiotensin receptor with unusual binding characteristics which is coupled to cellular proliferation. Biochem Biophys Alos Commun 1994; 204:1334-1339.

238. Neyses: $L_{\text {. }}$ Vetter $H$. Action of atrial natriuretic peptide and angiotensin II on the myocardium: studies in isolated rai ventricular cardiomyocytes. Biochern Biophys Res Commun 1989; 163:1435-1443.

239. No $Y_{*}$ Matsubava $H$. Murasawa $S$, Kanasaki M, Inada M. Regulation of gene transcription of angiotensin II receptor subtypes in myocardial infarction. J Cilin invest 1995; 95:46-54.

240. Nishik SO. Davis D, Youmans WB. Cardioaccelerator action of angiotensin II. Am J Physiol 1962; 202:237240.

241. Ohanian J. Ollerenshaw J, Colirs P. Heagerty A. Agonist-induced productian of 1,2 -diacylglyceral and phosphatidic acid in intact resistance arteries. Evidence that accumulation of diacylglycerol is not a prer由quisite lor contraction. J Biol Chem 1990; 265:8921-8928.

242. Okunishi $H_{1}$ Myazaki $M_{4}$ Okamura T, Toda N. Different distribution of two types of angiotensin II-generating enzymes in the eortic wall. Blochem Blophys Res Commun 1987: 149:1186-1192.

243. Oliver JA, Sciacca RR. Local generation of anglotensin II as a mechanism of regulation of peripherel vascular tone in the rat. J Cirn trovest 1984; 74:1247-1251.

244. Olivetti $G_{n}$ Anversa $P$. Long term pressure induced cardiac hypertrophy: capillary and mast cell production. Am J Physiol 1989:257:H1766-H1772.

245. Olivettl $G$, Capasso JM, Sonnenblick EH. Anverse $P$. Side-to-side slippage of myocytes participates in ventricular wall remodeling acutely after myocardial infarction in rats. Circ fies 1990; 67:23-34.

246. Olivetti $G$. Ricci $B$, Anversa P. Hyperplasia of myocyte nuclei in long term cardiac hypertrophy in rats. ${ }^{\prime}$ Clin Invest 1987: 80:1818-1821.

247. Ollerenshaw JD, Lassegue B, Alexander RW. Intracellular signaling in arteries and vascular smooth muscle cells in cullure. In: Mulvany Mu. ed. Resistance anteries, structure and function. Amsterdam: Elsevier. $1991: 73.76$.

248. Papdimitriou $A_{1}$ Worcel M. Dose-response curves for angiotensin ll and synthatic analogues in threa types of smooth muscle: existence of different forms of receptor sites for angiotensin II. Er J Pharmacol 1974: $50: 291.297$

249. Parker TG, Packer SE, Schneider MD. Peptida growth factors can provoke "fetal" contractile protein gene expression in rat cerdiac myocytes. J Clin Invest 1990; 85:507-514.

250. Paul M, Wagner D, Metzger $A$, Ganten D, Lang RE, Suzuki F, Murakami K, Burbach JH, Ludwig G. Quantification of renin mRNA in various mouse tissues by a nowel solution hybridization assay. $J$ Hypertens $1988 ; 6: 247.252$

25\%. Peach Mul. Anglotensin and blood pressure regulation. Orlanda FL:Academic., 1988.

252. Pfeffer JM, Pfeffer MA, Biraunwald $E$. Influence of chronic captopril therapy on the infarcted left ventricle of the rat. Cire Fies $1985 ; 57: 84.95$. 
253. Plefer MA. Braunwald E. Ventricuar remodeling after myocardiel interction. Exparmental observations and clinical implications. Crrculation $1990 ; 81.1161 \cdot 1172$

254. Pfetfer MA, Pfeffer JM, Steinberg $C$, Finn P. Survival after an experimental myocardial infarction beneticial effecis of long-term therapy with captopril. Circulation 1965; 72:406-412.

255. Philips MIl Stenstrom B. Amglotensin $\|$ in the rat brain comigrates whth authentic anglotensin in in high prassure liquid chromatography. Circ Res 1985; 56:212.

256. Pobiner BF. Hewlett EL, Garrison JC. Role of Ni in coupling angiotensin receptors to imbibition of adenylate cyclase in hepatocytes. I Blol Chem 1985: 260:16200-16209.

257. Pucell AG. Hodges JC, Sen 1, Bumpus FM. Husain A. Biochemical propentios of the ovartan granulosa call type 2-angiotensin II receptor. Endocinology 199\%; 128:1947-1950.

258. Quinn SJ, Cornwall MC. Wiliams GH. Electrophysiological responses to angiotensin ll of isolated rat adrenal glomerulosa cells. Enolocrinology 1987: $120: 1581-1589$.

259. Reiss $K_{\text {v }}$ Capasso JM. Huang HE, Meggs LG. L P, Anvarsa P. ANG If receptors, c-myc, and $c$-jun in myocytes after myocardial infarction and ventricular talure. Am I Physiol 1993; 264:H760-H769.

260. Rogers TB, GaA ST, Allen IS. Identification and characterization of functional angiotensiln II receptors on cultured heart myocyles. I Phamecol Exp Ther 1986; 236:430-444.

261. Ragg H, Schmid A, de-Gasparo M. Identification and characterization of anglotensiln Ill receptar subtypes in rabbil ventricular myocandium. Biochem Biophys Ros Commun *990; 173:416-422.

262. Rosenthal J. Lutterotti N, Thurnreiter M. Gomba S, Rothemund J, Reiter W, Kazda $S$, Garthof B, Jacob I, Dahimeim $H$. Suppression of reinin-angiotensin system in the hear of spontaneously hyperterns/ve rats. J Hypertens 1987; 5:S23-S31.

263. Ruzicka M, Leenen FH. Fenin-angiotensin system and minoxildill-induced cardiac hypertrophy in rats, Am J Physiol 1993; 265:H1551: -H1556.

264. Sadoshima 4 , Izumo $S$. Molecular characterization of anglotonsin Ill--inducad hypertrophy of cardiac myocytes and hyperplasia of cardiac tibroblasts. Critical role of the AT1 receptor subtype. Circ Res 1993; $73: 413-423$.

265. Sadoshima J. Takahashi $T_{\text {i Jahin }} \mathrm{L}_{\text {, }}$ Izumo $\mathrm{S}$. Roles of mechano-sensitive ion channels, cytoskeleton, and contractille activity in stretch-induced immediate-early gene expression and hypertirophy of cardiac myocytes. Proc Natl Acad Sci U S A 1992; 89:9905-9909.

266. Sadoshima $J_{1} X U, Y$, Slayter HS, Izumo S. Autocrine release of angiotensin If mediates stretch-induced hypentrophy of cardiac myocytes in vitro. Cell 1993;75:977-984.

267. Sakaguchi K. Chai SY, Jacksan B, Johmston Cl, Mendelsohn FAO. Inhibition of tissue anglotensin convar. thing enzyme. Quantitation by autoradiography, Hypertension 1968, 11:230-238.

268. Samani Nd, Morgan $K$, Brammar WJ, Swales JD. Detection of renin messenger ANA in rat tissues: increa. sed sensilivity using an RNAse protecton technique. A Hypartens Suppl 1987; 5:S19-S21.

269. Samuel JL, Barreux A, Dufour S, Dubus I, Conterd F, Koteliangky V. Farhadian F, Marotte F. "Thiery JP. Rappaport L. Accumulation of fetal fibronectin mRNAs during the development of rat cardica hypertrophy induced by pressure overioad. J Chin invesit 1991: 88:1737-1746.

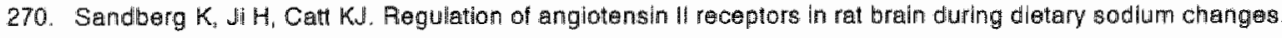
Hypertension 1994, 23 (Suppl. 1):1137.1141.

281. Sandberg $K$, w $H$, Glark $A J$, Shapira $H$, Catt KJ. Cloning and expression of a novel angiotensin II receptor subtype. J Blol Chem 1992; $2679455-9458$.

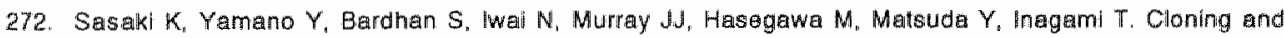
expression of a complementery DNA encoding a bovine adremal angiotensin II typo-1 receptor. Natura $1991 ; 351: 230-233$

273. Sasamura $H$, Hein $\mathrm{H}_{\text {, }}$ Krieger JE, al Cloning, characterization and expression of two angiotensin receptor (AT-1) Sotions from the mouse genome. Biochem Blophys Ras Commun 1992; 183:910-916. 
27.4. Schlondort D, DeCandido 8 , Satriano JA. Anglotensin lit stimulates phosphohlipases C and A.2 in cutured rat merangial cetls. Am of Physiol 1987;253:C113-C120.

275. Schneider MD. Parker TG. Cardiac myocyles as largets for the action of peptide growth factors. Circulation $1890 ; 81: 1443 \cdot 1450$.

276. Schneider MD, Roberts: $F_{\text {i }}$ Parker TG. Modulation of cardiac genes by mechanical stress. The oneogene signalling hypothesis. Mol Blol Hed $1991 ; 8: 167.183$.

277. Schoemaker RG, Debats JJM, Struyker-Boudier HAJ, Smits JFM. Delayed but not immediate captopril therapy improves cardiac function in consclous rats, following myocerdial infarction. J Mol Cell Cardiol $1991 ; 23: 187.197$.

278. Schorb W. Booz GW, Dostal DE, Conrad KM, Chang KC, Baker KM. Angiotensim II is mitogenic in neonatlal rat cardianc tibroblasts. Circ Pes $1993 ; 72,1245-1254$

279. Schulte KL. Meyer-Sabeliek W', Lederwald K, van-Gemmeren D, Lenz T. Gotzen R. Relation of regression of left wentricular hypertrophy lo changes in ambulatory blood pressure atter long-term therapy with perin. dopril wersus nifedipine. Am J Cardial 1992; 70:468-473.

280. Schunkert H. Dzau WJ Tang SS, Hirsch AT, Apstain CS, Lorell BH. Increased rat cardiac angiotensin conwerting enzyme actiwity and mRNA expression in pressure overload left ventricular hypertrophy. Effects on coronary resistance; contractility, and relaxation. J Clin invest 1990; 86:1913-1920.

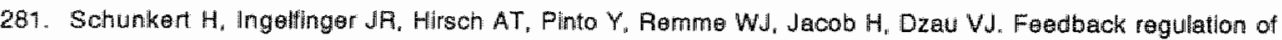
anglotensin converting enzyme actiwly and mRNA levols by anglotensin 11 . Chrc Res 1993; 72:312-318.

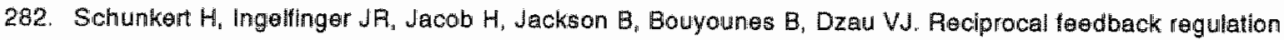
of kidney angiolensinogen and renin mFINA expressions by angiotens in II. Am I Physiol 1992; 263 :E863. E869.

283. Seajoy' JE. Atlac SA, Laragh JH. Prorenin and other larger molecular weight forms of renin. Endocr fiev $1980 ; 1: 365-381$.

284. Seikaly MG, Arant BS, Seney FD. Measurement of endogenous angiotensir lewols in glomerular filtrate and proximal tubule tuid (abstract). American Society of Nephrology. Proceedings of 22nd Annual Meeting. Washington, $\mathrm{DC}_{n} 1989 ; 171 \mathrm{~A}_{\text {. }}$

285. Sen S. Tarazl RC, Bumpus FM. Rewersal of cardlac hypertrophy in renal hypertensive rats: medicel ws. sulaical thelrapy. Am J Physiol 1981; 240:H408-H412.

286. Sharma JN, Fernandez $P$ G, Kim $8 K$, Idikio $H$, Triggie $C$. Cardlac regression and blood pressure control in the Dahl rat treated with ether onalapril maleate (MK 421, am anglotensin convering enzyme inhibitor) or hydrochlorothiazlde. A Hypertens 1983; 1:251-256.

297. Sheiban 1. Afcaro G, Covi G, Accardi A, Zenorini C. Lechi A. Regression of cardlac hypertrophy after antihypertensilve therapy with nifedipine and ceptoprl. 4 Cardiowasc Pharmacol 1987; 10 Suppl 10:S187. S191.

208. Shekhonin BV, Gurlev SB, Irgathev SB, Koteliansky VE. Immunofiuoresicence identlfication of fibronectin and librinogen/tibrin in experimental myocardial infarction. J Mol Coll Cardiol 1990; 22:533-541.

289. Shubeita HE, McDonough PM, Harris AN, Knowiton KU, Glembotski CO Brown JH, Chien KR. Endothelln induction of inositol phosphollpid inydrolysis, sarcomere assembly, and cardiac gene expression in veintticu. lar myocytes. A paracritno mechanism for myocardial cell hypertrophy. al Blof Chem 19910; 265:2055520562

290. Skidgel RA, Erctos EG. The broed substrate specificity of human angiotensin / converting enzyme. Clin Exp Hyportens A 1987; 9:243-259.

291. Smits JFM. Daemen MuAP. Insights from animal models of myocerdial infarction: do ACE inhibitors limit the structural response? Br Heast $J$ 1994; 72:61-64. 
292. Smits JF, vam-Krimpen C, Schoemaker RG. Cleufens JP. Daemen M. Anglotensin II neoptor blockade after myocardial infarction in rats: eftects on hemodynamics, myocardial DNA sinthesis, and interstital collagen content. I Cardiovasc Phamacol $1992 ; 20: 772-778$.

293. The SOLVD inwestigators. Elfect of entapil on surviwal in patients with reduced left ventricular ejection fractions and congesthe herert fature. N Engl J Med 1991; 325:293-302.

294. Speth AC, Kim KH. Discimination of two anglotensin II receptor subtypes with selective agonist analogue of anglotensin II, p-aminophenylalanine angiotensin II. Biochem Brophys Res Commun 1990; 169.997 1006 .

295. Stoll Mi, Steckelings M, Paul M, Bottari SP, Metzger R, Unger T. The angiotensin AT2-receptor mediates inhibition of coll prolferation in coronary endothelial cells. $J$ Chin /nvest 1995: 95:651.657.

296. Straber BE. Regression of myocardial and coronary vascular hypertrophy in hypentenisive disease. J Cardiowasc Phamacol 1988; 12 (Suppl, 4):S45-S54.

297. Studer R. Reinecke H, Muller B. Holiz J. Just H, Drexler H. increased angiotensin-l converting emzyme gene expression in the failing humen heart. J Clin Invest 1994; 94:301-310.

298. Sumners $C_{\|}$Tang $W$. Zelezna $\theta$, Raizada MK. Angiotensin II receptor subtypes are coupled with distinct signal-transduction mechanisms in meuroms and astrocytes from rat brain. Proc Nat Acad Sci U $S$ A 1991; $88: 7567 \times 7571$

299. Sun Y. Ratajska A, Zhou $G$, Weber KT. Angiotensin-conventing enzyme and myocerdial fibrosis in the rat receiving angiotensin $\|$ or aldosteron由. J Lab Clin Mad 1993; 122:395-403.

300. Sutton MS. Should angiotensin converting enzyme. (ACE) inhibitors bo used routinely after inferction? Perspectives from the Survival and Ventricular Enlargement (SAVE) trial. Br Haart $41994 ; 71: 415-118$.

301. Swerdberg $K$, Held P, Kjekshus J, Rasmussen $K_{n}$ Ryden $L_{\text {w }}$ Wedel $H$. on behall of the CONSENSUS II. Effects of the early administration of enalapril on mortally in patlents with acute myocardlal infarction. $N$ Engl I Mad 1992; 327:678-684.

302. Takada $Y$, Maruta $H$, Wagner $B, F A X+G$, dames $H L$ Erdos EG. Activation of human prorenin by neutroptht elastase. J Clin Endocrinol Molab 1987; 55:1225-1230.

303. Takahashi T, Schunkart H, Isoyama $S$, Wei JY, Nadal-Ginard B, Grossman W, lzumo S. Age-related differemces in the expression of proto oncogene and contractile protein genes in response to pressure overload in the rat myocardium. I Clin trwest 1992; 89:939-946.

304. Tan $L$, Jall JE, Pick $R$, Janicki JS, Webeir $K T$. Cardiac myocyte necrosis induced by anglotensin II. Circ Res $1991 ; 69: 1185.1195$.

305. Tang SS, Losicalzo J, Dzau VJ. Tissue plasminogen activator activates remin anglotensin in vitro. $J$ Vasc Mod Biol 1989; 1:67-74.

306. Tateishi $H_{1}$ Nasjletti $\mathrm{A}$, Masson $\mathrm{BMC}$. Fole of renin in the regulation of englotensinogen levels in plasma. Proc Soc Exp Biol Med 1971; 137:1424-1428.

307. Taugner $R$, Waldherr $R$, seyberth HW, Erdos EG, Menard i, Schnelder $D$. The juxtaglomerular apparatus In Barter"s syndrome and related tubulopathies. An immunocytochemical and electron microscopic study. Wirchows Arch A Pathol Anat Histopathol 1988; $412: 459 \times 470$.

308. Thompson $\mathrm{J}$. Eftect of angiotensin il in the cardiaaccelerator response to sympathetic nerve stimulation in isolated rabbit hearts. Proc Soc Exp Blal Mod 1970 135:825-B30.

309. Timmermans PB, Wong PC, Chil AT. Herblin WF, Bemfleld P, Carini DJ, Lee Ru, Wexler RR, Saye JA, Smith RD. Anglotensin II receptors and amgiotenstn II receptor entagonists. Phermacol Rev 1993,45:205. 251 .

310. Tomanek RJ, Wessel TJ: Harrison DG. Capillary growth and geometry during long-term hypertension and myocardiall hypertrophy in dogs. Am I Physiol $1991 ; 261: \mathrm{H} 1011-\mathrm{H} 1018$.

311. Tominaga M, Song G, lkemoto F, Yamemoto K. Effect af oxtdation on the activity of anglotensin conwerting onzyme in the rat kidney, heart and brain. Clin Exp Hypertens $A 1988 ; 10: 1271-1278$. 
312. Tsoporis J, Fiohds N, Lew AMRW, Lenen FHH. Arteris vasodilation and cardiovasicular changes: in nomotensive tats. Am I Physiol 199 1: 260:H1944-H1952.

313. Toutsum $K$, Savvedra JM. Heterogeneity of angiotensin II AT2 receptors in the rat brain. Mal Phamacol $1992 ; 41: 290-297$

314. Tsutsumi K. Strombery C, Viswanathan M, Saavedra JM. Arglatenein-1l receptor subtypes in fetal tissue of the rat: autoradiography, guanire rucleotide sensitivity, and association with phopsphoinositide hydrolysis. Enciochinology 1997; 129:1075-1082.

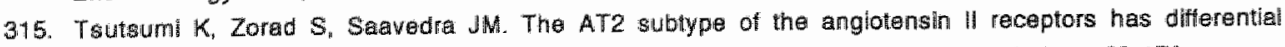
sensitivity to dithiothreitol in spectllc brain nuclol of young rats. Eur \& Phamacol 1992; 226:169-173.

316. Unger T, Badoar E, Ganten D. Lang FE, Rettig B. Brain angiotensin: pathways and pharmacology. Circulation $1988 ; 77: 140 \cdot 154$.

317. Unger T. Ganten D. Lang RE. Tissue converting enzyma and cardiovascular actions of converting enzyme: Inhibltors. $/$ Cardiovesc Phamacol 1986; 8, (Suppl. 10).S75-S81.

3.18. Unger T, Mattieildt. T, Lamberty V, Bock P. Mall G, Linz W, Schotkens BA, Gohlke P. Eftect of early onselt anglotensin conventing entyme inhibition on myocardial capillaries. Hypertension 1992; 20:478-482

318. Urata $H_{4}$ Boenm KD, Philip A, Kinoshita $A$, Gabrovsek J, Bumpus FM, Husain A. Cellular lacalization and reglonal distrbution of an angiotensin H-forming chymase in the heart. J Clin Invest 1993; 91:1269-1281.

320. Urate $H_{1}$ Healy $B$, Stewart RW. Bumpus FM. Husein A. Angiotensiln ll-forming pathways in normel and Halling human hearts, Circ Fies 19910; 66:683-890.

321. Uratg $H_{1}$ Kinoshita $A_{1}$ Mtisono MS, Bumpus FM, Husain H. Hentification of a highly specific chymase as the major anglotensin ll-forming enzyme in the human heart. J Bial Chem 1990 265:22348-22357.

322. Urata $H_{\varepsilon}$ Kinoshita $A$. Porez DM, Misono MS, Bumpus FM, Graham AM, Husain A. Cloning of the gene and CDNA for human heart chymase. J Biol Chem 19911; 266:17173-17179.

323. Velleirl $P A$, Lovenberg W. Biological regulation of testicular anglotensin I converting enzyme. Adv Exp Med Biol $1987 ; 198: 487.494$

324. Villarreal FJ, K/m NW, Ungab GD, Printz MP, Dilimann WH. Udentification of functional angiotensin II receptors on rat cardelac fibroblasts. Circulation 1993; 88:2849-2861

325. Viswanathan M, Saavedra JM. Expresslon of angiotensin II AT2 receptors un the rat skin during experimantal wound healing. Paptides 1992; 13:783-786.

326. Volders PGA Willems IEMG, Cleutens JPM, Arends JW, Havenith MG, Daemen MJAP. Interstitlal collagen is incraased in the nom infarcted myocardium after myocardial intarction. 1 Mol Coll Cardol $1993 ; 25: 317$ 323

327. Wang DH. Prewitt RL. Captopil reduces aortio and microvascular growth in hypertensive and normotensive rats. Hypertension 1990; 15:68-77.

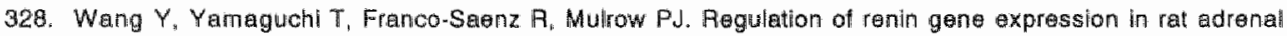
zona glomerulosa cells. Hypertension 1992; 20:776-781.

329. Webb ML, Liu EC, Cohen RB, Hedberg A, Bogosian EA, Monshizadegan $H_{1}$ Malloy $C_{8}$ Serafino Ri. More. land $S$, Murphy Tw, et all Molecular characterization of anglotinsin II type ll receptors in rat pheochromocytomer calls. Peptides 1992; 13:499-508.

330. Wabar KT, Brilla CG, Campbell SE, Guarda SE, Zhou G, Sriram K. Myocardial ibrosis: role of anglotensin II and aldosterone. Basic Res Cardiol 1993; 88 (Suppl. 1):107-124.

331. Wenting GJ, Bilankestijn PJ, Poldermans D, van Gealen J, Derkx FHM, Man in't Weld M, Schalekamp MADH. Blood pressure response of nephrectomized subjects and petients with essential hyperienston to ramipril; indirect ovidence that inthibition of tissue anglotensin converting enzyme is important. Am $A$ Cardiol $1987: 59: 920-970$.

332. Whitebread $S$, Mele M, Kamber $B$, de-Gasparo M. Prelliminary biochemical characterization of two anglotensin 11 roceptor subtypes. Bioch am Biophys Alos Commum $1989 ; 163: 284-291$. 
333. Wiesman $\mathrm{H}$, Bush D. Mamnisï J. Celluar mechemisms of myocardiat infarct axpansion. Gircuaton 1988; 78:186-204.

334. Willems IEMG, Havenith MG, De Mey JGR, Daemen MAA. The alpha-smooth muscle actim-posilwo colls in healing human myocerdtal scars. Am J Pathot 1994; 145:868-875.

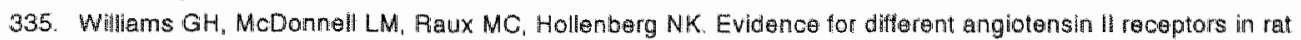
adrenal glomerulose and rabbit vascular smooth muscle cells. Circ Res 1974:34:383.

336. Wintroub BU, Klickstein LB, Watt KW. A human neutrophil dependent pathway for generation of anglotensin II. al Chin Invest 1981; 68:484-490.

337. Wong PC Hart SD, Duncia JV, et al. Nonpaptide angiotensin II receptor antagonists. Xilt. Studies with DuP 753 and EXP3174 in dogs. Eur J Pharmacol 1991; 202:323-330.

338. Wong PC $\mathrm{PC}_{n}$ Hart SD. Timmermans PBMWM. Effect of angiotensin ll antagonisin on canine renal sympathetit narve function. Mypertension 1991; 17(6,P1 2):1127-1134.

339. Wong PC. Hart SD, Zaspel AM, Chil AT, Ardecky RJ, Smith RD, Timmermans PG. Funcitonal studies of nonpeptide angiotensin II receptor subtype-specific llgands: DuP 753 (All-1) and PD123177 (All-2). of Phamacol Exp Ther 1990; 255:584-592.

340. Wong PC, Price WA, Chiu AT, Duncia JW, Carini DJ, Wexler RA, Johnson AL, Timmermans PB. Nompept:de angiotensin II receptor antagonists: Studies with EXPQ270 and DuP 753. Hypertension 1990; 15:823. 834 .

341. Wright JW, Roberts KA, Harding JW. Drinking to intracerebrowentricularly infused anglotensin II, III, and IV in the SHR. Peptides 1988, 9:979-984.

342. Yamada $H_{4}$ Fabris $B$, Allen $A M$, Jacksan $B$, Johnston $\mathrm{Cl}$, Mendelsohn $\mathrm{AO}$. Localization of anglotensin converting enzyme in rat heart. Circ Fes 1991; 68:141-149.

343. Zarahn ED, $Y$ $X$, Ades AM, Reagan LP. Fluharty SJ. Angiotensin-induced cycilo GMP production is mediated by multiple receptor subtypes and nitric oxide in N1E.115 neuroblastomia cells. J Nourochem 1992; $58 \div 1960-1963$.

344. Ziertiut W, Zimmer HG. Significance of myocardiall alpha- and beta-adrenoceptors in catecholamine. induced cardiac hypertrophy. Chrc Res $19.89: 65: 1417-1425$.

345. Ziogas J, Story DF. Fand MJ. Effects of locally ganerated All on noradrenergic transmission in guinea pig is olated atrie. Eur J Pharmacol 1985; 106:11-18. 


\section{CHAPTER 2}

MATERIALS AND METHODS 


\subsection{ANIMALS}

Adult male Wistar rats (chapter 4) or Wistar Kyoto (WKM) rats (chapters 3, 5, 6 and 7) were used (body weight $250-300 \mathrm{~g}$ at the start of the experiments). The experiments were performed according to the institutional guidelines for care and use of laboratory animals. All rats were given standard rat chow and water ad libitum.

\subsection{SURGERY}

\subsubsection{Myocardlal Infariction}

Animals were anesthetized with pentobarbital $(60 \mathrm{mg} / \mathrm{kg} \mathrm{i.p.)}$ and ventilated by positive pressure through an endotracheal tube attached to a Harvard small animal respirator. Via a left-sided thoracotomy and opening of the pericardium, the left anterior descending coronary artery (LAD) was ligated, which results in infarction of the free left ventricular wall $(6,8)$. After closing the chest, Lidocaine (Xylocaine, ASTRA, Riljswijk, The Netherlands) was given $i . m$. ( $2 \mathrm{mg} / \mathrm{kg}$ ) to reduce the incidence of ventricular arrhythmilas. In the sham procedure a superficial suture was placed in the epicardium of the left ventricle, near the LAD.

\subsubsection{Bllateral nephrectomy}

Animals were anesthetized with ether. Two dorsal lateral incisions were made and both kidneys were removed and the wounds were closed. In the sham group two dorsal incisions were made, but kidneys were not remowed. Twenty-four hours later the animals were sacrificed in ether anesthesia.

\subsubsection{Abdominal aorta coarctation}

The animals were anesthetized with ether. The abdominal aorta was exposed through a midline abdominal incision. In the experimental group a needle with a diameter of $0.6 \mathrm{~mm}$ was placed adjacent to the abdominal aorta between the renal arteries. A ligature was tightened around the aorta and the needle. The needle was removed, resulting in a constricted aorta with the diameter of the needle. In shamoperated rats the abdomen was closed after exposure of the aorta. Seven days after surgery the animals were sacrificed in ether anesthesia.

\subsubsection{Captopril treatment}

Animals were anesthetized with ether. Rats received the ACE-inhibitor captopril ( 0.5 $\mathrm{mg} / \mathrm{kg} / \mathrm{hr}$ ) for 24 hours (chapter 3 ) or for 7 days (chapter 7 ) by subcutaneously implanted osmotic minipumps (Alzet model 2001. Alza Corp., Palo Alto, Ca, USA). Before implantation the minipumps were placed in $0.9 \% \mathrm{NaCl}$ at $37^{\circ} \mathrm{C}$ for 4 hours. 


\subsection{TISSUE PROCESSING}

At the end of the experiments animals were sacrificed by deep ether anesthesia. The tissues of interest were removed. After myocardial infarction or sham-surgery a slice of tissue, which was taken at the mid-sagital level and parallel to the base of the heart, was formalin fixed overnight in $10 \%$ phosphate buffered formalin (pH 7.4), routinely processed and paraffin embedded for determination of the infarct size. The rest of the heart was divided in the (infarcted) left ventricle, septum and right ventricle and quickly frozen in liquid nitrogen and stored at $-70^{\circ} \mathrm{C}$ for RNA isolation or angiotensin I-converting-enzyme (ACE)-activity determination.

\subsubsection{Morphometric analysis}

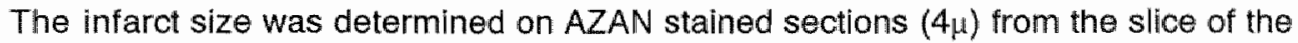
heart using a computerized morphometric system (Quantimet 570, Leica, Cambridge, U.K.). Infarct size was expressed in percentage of the left ventricular circumference (2).

\subsubsection{RNA Isolation}

Total RNA was extracted using the LiCl/urea method (9). Tissues were homogenized in $3 \mathrm{M} \mathrm{LiCl} / 6 \mathrm{M}$ urea and centrifuged afterwards. The pellet was dissolved in 10 $\mathrm{mM}$ Tris pH $7.8 / 0.5 \%$ SDS (sodium dodecyl sulfate). After homogenizing the tissues and phenol/chloroform/isoamylalcohol (IAA) extraction, RNA was precipitated with 2.5 volumes of ethanol and 0.1 volume of $3 \mathrm{M} \mathrm{NaAC}(\mathrm{pH} 5.3)$. The RNA concentration was measured by spectrophotometry at $260 \mathrm{~nm}$. RNA integrity was verified by gel electrophoresis.

\subsection{COMPETITIVE REVERSE TRANSCRIPTASE POLYMERASE CHAIN REACTION}

Competitive reverse transcriptase PCR (RT-PCR) uses an internal standard. This standard was created by making a shorter fragment (deletion) with restriction enzymes in the target sequence. This results in identical primer sequences for the target and the internal standard fragments. Tissue total RNA and internal standard RNA are converted in the same tube into cDNA, which is subsequently amplified in the presence of specific primers by a DNA polymerase. By performing a competitive RTPCR of the target fragment and its competitor in the same tube, differences in amplification efficiencies can be minimized (figure 1). 


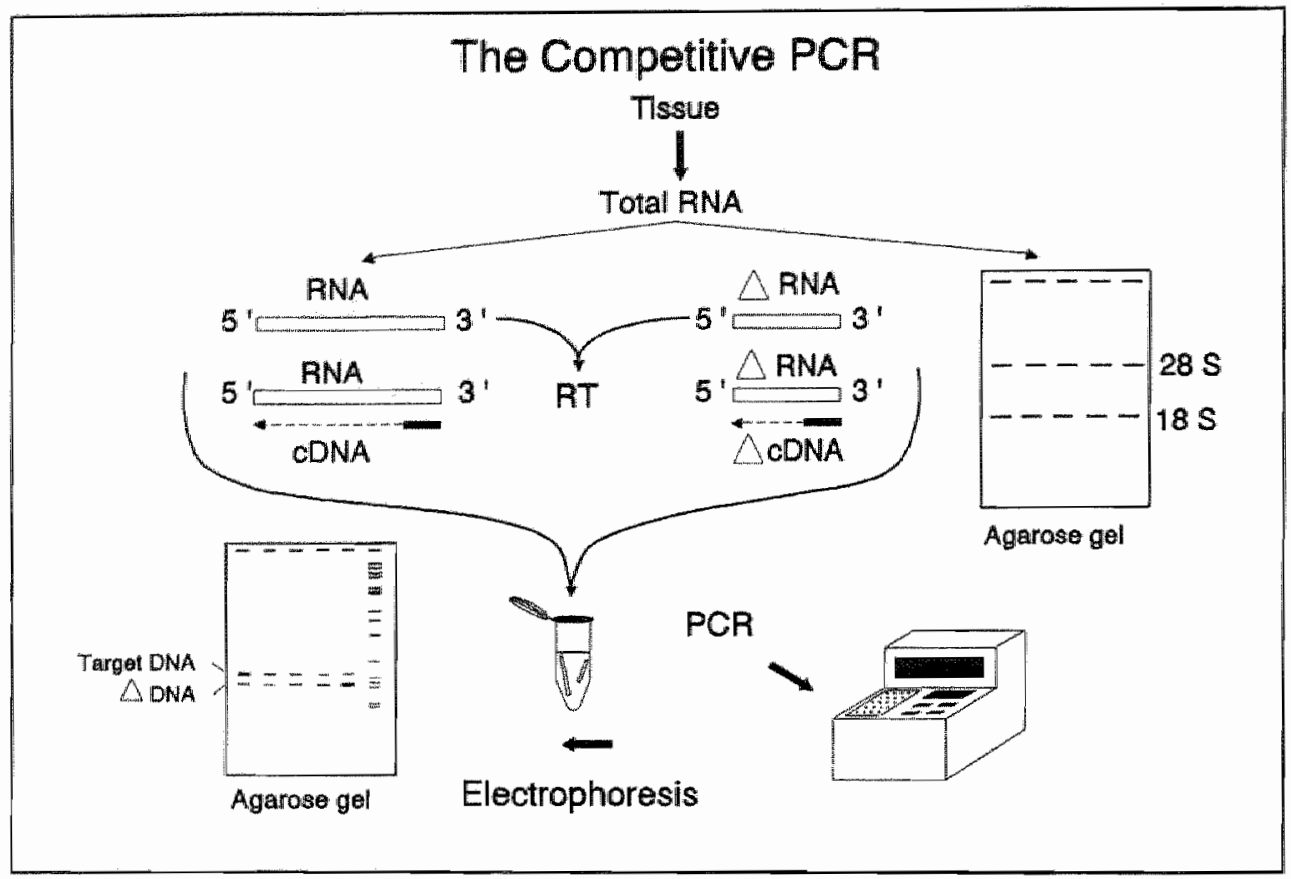

Flgure 1. The competitive reverse transcriptase polymerase chain reaction (RT PCR). Internal standard $(\triangle)$ and total FNA are converted into CDNA in the same tube and subsequently amplified by PCR. Total RNA is also brought on a agarose gell for measuring the ribosomal RNA bands ("8 and $28 \mathrm{~S}$ ).

\subsubsection{Selecting speciflc primers}

\section{angiotensinogen}

Angiotensinogen (AO) primers were chosen at the second and third exons of the rat AO CDNA sequence (5). The sequence of the upper (sense) primer was $5^{\prime}$ CAACAGGTGTAGCCAGTGGG 3', base pairs (bp) 344 to 363 , and of the lower (antisense) 5' AGCTGGGAGAAGCCTCTCAT $3^{\prime \prime}$ (bp 835 to 854). A second set of specific AO primers was used (nested primers) for increasing the amount of the specific AO amplification product. In the second set of primers the sequence of the upper primer was $5^{\prime}$ GGGCCGTCCTCTCTCCA $3^{\prime \prime}$ (bp 362 to 378 ) and of the lower $5^{n}$ GCCTCTCATCTTCCCTTGG 3' (bp 825 to 843), spanning the second and the third exon. Amplification by sequentially using these two sets of primers resulted in a 482 bp PCA fragment. Southern blotting of this PCR fragment and hybridizing with a ${ }^{32} \mathrm{P}$ labeled AO rat probe, revealed the specifity of this fragment (data not shown). 
renin

Renin primers were selected at the sixth and ninth exon of the rat renin cDNA sequence (1). The sequence of the upper primer was 5 CTGGGAGGCAGTGACGCTCAACATTACCAG 3' (bp 747 to 776) and of the lower 5" GAGAGCCAG TATGCACAGGTCATCGTTCCT $3^{\prime}$ (bp 1089 to 1118). Amplification by using these primers resulted in a 372 bp PCR fragment. Renin specifity of the PCR-fragment was demonstrated by Southern blotting of the PCR fragment and hybridizing with a ${ }^{32} \mathrm{P}$ labeled rat renim probe (data not shown).

\section{angiotensin converting enzyme}

The human ACE CDNA sequence (10) was used for selecting ACE-primers. The sequence of the upper (sense) primer was $5^{\prime}$ GCCTCCCCAACAAGACTGCCA $3^{\prime}$ (bp 492 to 512) and of the lower (antisense) $5^{\prime}$ CCACATGTCTCCCAGCAGATG $3^{\prime}$ (bp 860 to 880 ). The cDNA sequence of the lower ACE primer was identical to the recently cloned rat ACE CDNA sequence (3). The CDNA sequence of the upper primer revealed 1 mismatch, when compared to the rat ACE CDNA sequence. Amplification of lung cDNA resulted in a $389 \mathrm{bp}$ fragment. The specificity of this product was checked by sequencing (Sanger method), by hybridizing the PCRfragment (after Southern blotting) with a ${ }^{32} \mathrm{P}$ labeled human ACE cDNA probe (10), and by Northern blot hybridization, hybridizing total rat lung RNA with the ${ }^{32} \mathrm{P}$ labeled PCR fragment. Sequencing of the 389 bp PCR fragment resulted in a homology of $100 \%$ with the rat $A C E$ CDNA sequence (3). Southern and Northern blot hybridizations resulted in positive signals at the appropriate heights (data not shown).

\subsubsection{Internal standards}

After gel ellectroelution, the PCR-fragments were digested with specific restriction enzymes. The ACE PCR fragment was digested by Hha I (Promega), the renin PCA fragment was digested by Apal and Nael (Promega), and the AO PCA fragment was digested by Hpall (Promega). Digestion of the PCR fragments resulted in three fragments of different lengths. Again by gel electroelution the $5^{\prime}$ and $3^{\prime}$ fragments of each gene were separately isolated and consequently ligated with 1 U of T4 DNA ligase (Promega) at $15^{\circ} \mathrm{C}$ overnight. Subsequently, the ligation product was amplified ( 35 cycles), using the following cycle profile for all genes: $1 \mathrm{~min}$ at $94^{\circ} \mathrm{C}, 1 \mathrm{~min}$ at $65^{\circ} \mathrm{C}$, and 1 min at $72^{\circ} \mathrm{C}$. This was concluded with 10 min at $72^{\circ} \mathrm{C}$, which results in a $3^{\prime}$ adenosine nucleotide overhang at the amplified products. This deletion fragment was checked by agarose gel electrophoresis for length and purity. Afterwards the deletion fragment was ligated for 15 hours at $15{ }^{\circ} \mathrm{C}$ with $2 \cup$ T4 DNA ligase in the presence of the TA-vector (Stratagene, molar ratio $3: 1,1: 1$ and $1: 3$ ), containing a $3^{\prime}$ thymidine overhang and a T7 and Sp6 RNA polymerase site. After linearizing the plasmid with Hindlll (Promega), RNA was transcribed with $1 \cup \mathrm{T} 7$ 
Table 1: Length in base pairs of the target DNA and the internal standard DNA fragments of the different components of the RAS for the competitive AT-PCA

\begin{tabular}{lccc}
\hline & Anglotensinogen & Renin & ACE \\
Target length (bp) & 482 & 372 & 389 \\
Internal standard length (bp) & 372 & 263 & 291 \\
\hline
\end{tabular}

$b p=$ base pairs; $A C E=$ angiotensin l-converting-enzyme

RNA polymerase (Promega), 1 hour at $37^{\circ} \mathrm{C}$. Plasmid DNA was removed by electroelution, followed by DNAse treatment with $5 \cup$ of RQ1 DNAse (Promega), 30 min at $37^{\circ} \mathrm{C}$. The concentration of the internal standard RNA was measured by spectrophotometry at $260 \mathrm{~nm}$ and integrity was checked on a $1 \%$ agarose gel. Possible plasmid DNA contamination was ruled out by amplification of the RNA. For stabilizing the standard RNA, $30 \mu \mathrm{g} / \mathrm{ml}$ tRNA was added. The lengths of the internal standards of the different components of the RAS are shown in table 1.

\subsubsection{Reverse transcription}

In the same tube, total RNA was mixed together with increasing amounts of the standard RNA. ( $1 \mathrm{fg}$ to $50 \mathrm{fg}$ AO standard RNA per $500 \mathrm{ng}$ total RNA, 10 fg to $400 \mathrm{fg}$ renin standard ANA per $500 \mathrm{ng}$ total RNA, $200 \mathrm{fg}$ to $5 \mathrm{pg}$ ACE standard RNA per $500 \mathrm{ng}$ total RNA, 6 concentrations/RNA sample) in $1 \times$ RT-buffer (50 mM Tris-HCl, $\mathrm{pH} 8.3,75 \mathrm{mM} \mathrm{KCl}$ and $3 \mathrm{mM} \mathrm{MgCl}$ ), $1 \mu \mathrm{M}$ of random hexanucleotide primers (Promega) and $2 \mathrm{mM}$ dNTP (Pharmacia) sterile water was added to a volume of $10.5 \mu \mathrm{l}$. This was placed at $72^{\circ} \mathrm{C}$ for $3 \mathrm{~min}$ and cooled at $42^{\circ} \mathrm{C}$. Hereafter $10 \mathrm{mM}$ dithiothreitol, RNase inhibitor (10 U; $1.6 \mathrm{U} / 100 \mathrm{ng}$ total RNA; Promega) and M-MLVRT (50 U; 8 U/100 ing total RNA; Gibco) were added to a final volume of $12.5 \mu \mathrm{l}$ and incubation was performed for 1 hour at $42^{\circ} \mathrm{C}$.

\subsubsection{Polymerase chain reaction}

The cDNA fragments from each reverse transcription reaction was amplified in duplicate. Five $\mu$ l of the reverse transcription mixture was added to $20 \mu l$ of a PCRmix, containing $20 \mathrm{mM}$ Tris-HCL, pH $8.3 .50 \mathrm{mM} \mathrm{KCl}, 20$ pmol of both the lower and upper primers (vide supra) and 1.25 U AmpliTaq DNA polymerase (Perkin \& Elmer) The final $\mathrm{MgCl}_{2}$ concentration varied for the different components $\left(2 \mathrm{mM} \mathrm{MgCl}_{2}\right.$ for the first PCR of $\mathrm{AO}, 1 \mathrm{mM} \mathrm{MgCl}$ for the second $\mathrm{PCR} ; 3 \mathrm{mM} \mathrm{MgCl}$ for renin: $1 \mathrm{mM}$ $\mathrm{MgCl}_{2}$ for ACE). The amplification profile for the different components of the RAS was as follows: $A O ; 0.5$ min $94^{\circ} \mathrm{C}, 0.5 \mathrm{~min} 62^{\circ} \mathrm{C}, 1$ min $72^{\circ} \mathrm{C}, 20$ cycles. After amplification, $3 \mu$ l was used for a second PCR with nested primers in $22 \mu 1$ of the 
PCR-mix. The profile of the second PCA was also $0.5 \mathrm{~min} 94^{\circ} \mathrm{C}, 0.5$ min $62^{\circ} \mathrm{C}, 1$ min $72^{\circ} \mathrm{C}, 20$ cycles. For renin the amplification profile was 0.5 min $94^{\circ} \mathrm{C}, 0.5 \mathrm{~min}$ $65^{\circ} \mathrm{C}, 1 \mathrm{~min} 72^{\circ} \mathrm{C}, 40$ cycles. For ACE the amplification profile was $0.5 \mathrm{~min} 94^{\circ} \mathrm{C}$. $0.5 \min 65^{\circ} \mathrm{C}, 1 \mathrm{~min} 72^{\circ} \mathrm{C}, 30$ cycles.

\subsubsection{Quantification of the PCR fragments}

After amplification, $10 \mu \mathrm{l}$ of the PCR fragments were separated by electrophoresis on a $1.5 \%$ agarose gel, containing ethidium bromide. By UV irradiation the two fragments were detected and photographed (Polaroid positive/negative, type 665). The negative film was used for measuring the optical density of the two fragments by a densitometer (Pharmacia). The value of the optical density of the internal standard was multiplied by the ratio of target DNA bp/standard DNA bp, thereby correcting for the difference in ethidium bromide density, caused by the difference in length between the target fragment and the internal standard. The mean values of the duplicate samples were plotted as the logarithm of the ratio of the internal standard to the target fragment against the logarithm of the known amount of internal standard RNA in each tube. The line of best fit and the correlation coefficient (r) were calculated. If $r^{2}$ was below 0.95 data were discarded. The logarithm value of zero on the $y$-axis represents the equivalence point, indicating the equal amount of internal standard RNA and target RNA. Equal amounts of RNA, as used in the competitive RT-PCR, were brought in duplicate on a $1 \%$ agarose gel. The total amount of $500 \mathrm{ng}$ of standard total RNA and sample RNA were brought onto gel in triplicate and duplicate, respectively. The mean values of the RNA samples were related to the mean of the standard total RNA. The mRNA amount is expressed in femto (f)g or atto (a) $g / 100 \mathrm{ng}$ of total RNA. The mean mRNA amounts ( $t$ SEM) of 3 animals are given. The mRNA amounts in the compartments of the heart at the different time points in the infarcted and the sham group are evaluated. The interand intra-assayvariation of the competitive RT-PCA were $13 \%$ and $11 \%$ for $\mathrm{AO}$,

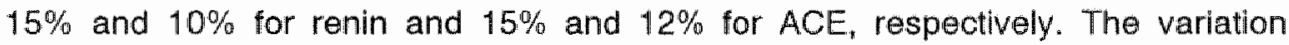
between the duplicate values after PCR was less than $5 \%$.

\subsection{NORTHERN HYBAIDIZATION ANALYSIS}

$15 \mu \mathrm{g}$ total RNA was dissolved in $30 \mu \mathrm{l}$ sample buffer containing $10 \mathrm{mM}$ sodium phosphate $(\mathrm{pH} 7)$, dimethylsulfideoxide (DMSO) and glyoxal. After denaturation (1 hour at $50^{\circ} \mathrm{C}$ ) the samples were electrophoresed in a $1 \%$ agarose gel with a $10 \mathrm{mM}$ sodiumphosphatebuffer $(\mathrm{pH} \mathrm{7)}$ for 3 hours at $100 \mathrm{~V}$ and subsequently transferred to a Hybond $\mathrm{N}^{*}$ membrane.

\subsubsection{Labelling of cDNA and hybrldization}

The cDNA probes used in the experimental chapters are shown in table 2. The 
Table 2: Length in base pairs of the probes used for Northern hybridization analysis.

\begin{tabular}{lcccccc}
\hline & AO & Renin & ACE & ANF & 185 & 285 \\
Probe length (bp) & 1634 & 1425 & 389 & 697 & 750 & 2100 \\
\hline
\end{tabular}

bp $=$ base pairs; $A O=$ angiotensinogen; $A C E=$ angiotensin-converting-enzyme; $A N F=$ atrial natriluretic factor.

probes were labeled by the random priming method using $\alpha-{ }^{32} \mathrm{P} d C T P$. After 1 hour prehybridization the radioactive probe was added (a total of 300.000 counts per minute of the radioactive probe per $\mathrm{ml}$ hybridization $\mathrm{mix}$ ) and hybridized for 18 hours at $42^{\circ} \mathrm{C}$, followed by washes in $2 X$ standard saline citrate (SSC). After exposure of the autoradiogram the blot was stripped in bidest at $100^{\circ} \mathrm{C}$ for 30 minutes and rehybridized with another cDNA probe. By using the 185 (4) or 285 probe for rehybridization, autoradiographic signals of the probes of interest could be related to the 185 or 285 probe autoradiographic signal (vide infra). Washing and hybridization of this probe were performed at $65^{\circ} \mathrm{C}$ instead of $42^{\circ} \mathrm{C}$.

\subsubsection{Autoradlography}

Hybridization signals were visualized by exposing the membrane to a X-ray fillm (Kodak) at $-70^{\circ} \mathrm{C}$ in the presence of an intensifying screen. This autoradiogram was scanned with the use of a densitometer. The $18 \mathrm{~S}$ signal was used as the internal standard, and the ratios of the signals of the probes of interest and the $18 \mathrm{~S}$ or $28 \mathrm{~S}$ probe was determined. On every blot one probe/18S or probe/28S ratio of a shamoperated animal was given the value of 1 . All other probe/18S or probe/28S ratios on that blot were normallzed to that valule.

\subsection{IN SITU HYBRIDIZATION}

The PCR fragments of the different components of the RAS, described above, were ligated in the TA-vector. ${ }^{35} \mathrm{~S}$ - or ${ }^{33} \mathrm{P}$-UTP-labeled antisense riboprobe was created by transcription using T7 RNA polymerase. Plasmid DNA was removed by RQ1 DNase treatment and the probe was precipitated after phenol/chloroform extraction. Sections $(4 \mu \mathrm{m})$ of formalin fixed, paraffin embedded hearts were cut from infarct and sham hearts 4 days after surgery and dried for $5 \mathrm{~min}$ at $55^{\circ} \mathrm{C}$. Pretreatment consisted of 10 min fixation in $4 \%$ paraformaldehyde, followed by proteinase $K$ ( 2 $\mu \mathrm{g} / \mathrm{mll}$ ) treatment for $10 \mathrm{~min}$ at room temperature. Hereafter the sections were incubated for 1 hour in a prehybridization buffer $(50 \%$ formamide, $0.3 \mathrm{M} \mathrm{NaCl}, 20$ $\mathrm{mM}$ Tris $\mathrm{pH} 8,5 \mathrm{mM}$ EDTA, $0.02 \%$ polyvinyl-pyrrolidone, $0.02 \%$ Ficoll, $0.02 \% \mathrm{BSA}$, $10 \%$ dextran sulphate, and $10 \mathrm{mM}$ DTT) at $37^{\circ} \mathrm{C}$. Hybridization was performed 
overnight at $55^{\circ} \mathrm{C}$ after addition of $600.000 \mathrm{cpm}$ of the ${ }^{35} \mathrm{~S}$ or ${ }^{33} \mathrm{P}$ labeled probe per section. This was followed by a wash in 2 X SSC, 1 mM EDTA and $10 \mathrm{mM} \beta$-mercaptoethanol for $10 \mathrm{~min}$, RNase treatment and 2 washes in SSC. After dehydration and drying, the sections were dipped in NTB-2 nuclear emulsion (Kodak, Technorama, Zürich, Switzerland) in the dark. The sections were developed after 3-6 weeks with Kodak D19 and fixed in $0.8 \mathrm{M}$ sodium thiosulfate and $0.09 \mathrm{M}$ potassium disulfate. Finally, the sections were counterstained with hematoxylin and examined by bright-field and dark-field microscopy.

\subsection{BIOCHEMICAL ASSAYS}

\subsubsection{Plasma anglotensin II concentration}

A total of $2 \mathrm{~m} /$ blood was drawn, just before sacrifice, via a catheter in the abdominal aorta and collected in heparinized tubes containing EDTA. The plasma concentrations of ANG I or ANG II were determined by radioimmunoassay. At the end of the incubation periods antibody-bound ANG | or ANG II were separated from unbound ANG I or ANG II using anti-sheep (donkey) coated cellulose in suspension as the solid phase. Following a brief incubation and centrifugation, the unbound ANG I or ANG II was decanted and the antibody-bound $1^{125}$ radiolabeled ANG I or ANG II was measured in a gamma counter. Using a standard curve, sample concentrations were expressed in picomoles per $\mathrm{ml}$. The lower limit of detection was $1.1 \mathrm{fmol} /$ tube for ANG I and $0.7 \mathrm{fmol} /$ tube for ANG II. Intra-assay coefficient of variation was $7.3 \%$ and inter-assay variation was $14.1 \%$

\subsubsection{Plasma renin activity}

A total of $2 \mathrm{ml}$ blood was drawn, just before sacrifice, via a catheter in the abdominal aorta and collected in heparinized tubes containing EDTA. Plasma renin activity was measured by incubation of plasma at $37^{\circ} \mathrm{C}$ and $0^{\circ} \mathrm{C}$ for 2 hours in the presence of $\mathrm{AO}$ and expressed as the formation of ANG I (pg/ll.min), measured by radioimmunoassay.

\subsubsection{Tissue ACE activlty}

This method was described by Pinto et al. (7). Briefly, after rinsing the tissue, it was homogenized in $50 \mathrm{mM} \mathrm{K}_{2} \mathrm{HPO}_{4}$ homogenate $(\mathrm{pH} 7.5)$. The sample was diluted and $100 \mu \mathrm{l}$ was transferred into a $0.5 \mathrm{M} \mathrm{K}_{2} \mathrm{HPO}_{4}$ buffer $(\mathrm{pH}$ 7.5). As a substrate, $100 \mu \mathrm{l}$ of $12.5 \mathrm{mM}$ hippuryl-His-Leu (Sigma), which is converted by ACE into His-Leu, was then added and incubated at $37^{\circ} \mathrm{C}$ for exactly $10 \mathrm{~min}$. In this amount the substrate is present in excess and is thus not rate-limiting. The conversion of the substrate was stopped by adding $1.45 \mathrm{ml}$ of $0.28 \mathrm{M} \mathrm{NaOH}$, after which $100 \mu \mathrm{l}$ of $1 \%$ phtaldialdehyde was added. This adheres to the His-Leu product. The amount of tagged His-Leu 
was then determined fluorimetrically at an excitation wavelength of $364 \mathrm{~nm}$ and an emission wavelength $486 \mathrm{~nm}$. This is a measure of the amount of His-Leu generated by $A C E$ in the sample. In blank samples, conversion of the substrate was prevented by prior addition of $\mathrm{NaOH}$. The sensitivity of this assay is less than or equal to 0.02 nmol.mg ${ }^{-1}$ tissue. min $^{41}$; the generation of the product His-Leu is linear from 0.02 to $15 \mathrm{nmol} . \mathrm{mg}^{-1} \cdot \mathrm{min}^{-1}$ in each tissue (7).

\subsection{IMMUNOHISTOCHEMISTRY}

Four $\mu \mathrm{m}$ sections were cut from paraffin embedded hearts from the sham group and infarct group, at 4 days after the operation. The sections were deparaffinized in xylene and $100 \%$ ethanol, followed by blocking the endogenous peroxidase in $0.3 \%$ $\mathrm{H}_{2} \mathrm{O}_{2}$ in methanol. After washing in Trisbuffered saline $(0.14 \mathrm{M} \mathrm{NaCl}, 4 \mathrm{mM}$ Tris- $\mathrm{HCl}$ $\mathrm{pH} 7.4$; TBS) the sections were incubated with a 1:1000 dilution of the ACE antibody (goat- $\alpha$-rabbit lung; polyclonal, gift of Dr. Soffer) for 1 hour at room temperature. Sections were washed in TBS, followed by incubation with a rabbit-anti-goat peroxidase labeled conjugate (1:1000; DAKO) for $45 \mathrm{~min}$ at room temperature. 3,3'Diaminobenzidine was used as the chromogen. The sections were counterstained with hematoxylin, dehydrated and mounted.

\subsection{STATISTICAL ANALYSIS}

All data are presented as mean \pm SEM. Statistical differences were calculated using the nonparametric Mann-Whitney $U$ test (chapter 3), two way analysis of variance (ANOVA) (chapter 4, 5 and 6) or Kruskal-Wallis test (chapter 7). ANOVA was followed by Bonferroni's t-test if differences existed between the groups (11). Statistical Significance was accepted at the level of $p<0.05$.

\section{REFERENCES}

1. Burnham CE, Hawelu-Johnson CL, Frank BM, Lynch KR. Molecular cloning of rat renin CDNA and its gene. Proc Natt Acad Sci U S A 1987; 84:5605-5609.

2. Fishbein MC. MacLaan $D_{*}$ Maroko PR. Experimental inyocardial infarction in the rat. Am $J$ Pathor $1978 ; 90: 57-70$.

3. Koike G, Krieger JE, Jacob HJ, Mukoyama M, Pratt RE, Dzau WJ. Angiotensin converting enzyme and genetic hypertension: cloning of rat CDNAs and characterization of the enzyme. Biochern Biophys Res Commun 1994; 198:380-386.

4. Oberbaumer 1. Retroposons do jump: a B2 element recently integrated in an I8S rDNA gene. Nucleic Acids Fies 1992; 20:671-677.

5. Ohkubo $H$, Kageyama $R$, Uijhara $M$, Hirose $T$, Inayama $S$, Nakanishi $S$. Cloning and sequence analysis of cDNA for rat angiotensinogen. Proc Natl Acad Sci U S A 1983; 80:2196-2200.

6. Pfeffer MA, Pfeffer JM, Fishbein MC, Fletcher PJ, Sparado J, Kloner RA, Braunwald E. Myocardial infarct size and ventricular function in rats. Circ Res 1979; 44:503-512. 
7. Pinto $Y M$, de-Smet $B G$, van-Gillst $W H$, Scholtens $E$, Monnink $S_{*}$ de-Graeff $P A$, Wesseling $H$. Selective and time related activation of the cardiac renin-anglotensin system after experimental heart fallure: relation to ventricular function and morphology. Cardiovasc Res 1993; 27:1933-1939.

8. Schoemaker RG, Debets JJM Struyker-Boudier HAJ, Smits JFM. Beneficial hemodynamic effects of two weeks milrinone treatment in conscious rats with heart failure. Eur I Pharmacol 1990; 182:527-535.

9. Searle PF, Tata FJ. Vitellogenin gene expression in male xenopus hepatocytes during primary and secondary stimulation with estrogen in cell cultures. Cell 1981; 23:741-747.

10. Soubrier $F$, Alhenc-Gelas $F$, Hubert $C$, Allegrini J, John $M_{n}$ Tregear $G$, Corval $P$. Two putative active centers in human angiotensin 1-converting enzyme revealed by molecular cloning. Proc Natf Acad Sci U S A 1988; 85:9386-9390.

11. Wallenstein $S_{n}$ Zucker $C L$, Fleiss $\mathrm{JL}$. Some statistical methods useful in circulation research. Circ Fies 1980; 47:1-9. 


\section{CHAPTER 3}

DIFFERENTIAL REGULATION OF ANGIOTENSINOGEN AND RENIN MESSENGER RNA FOLLOWING INTERVENTIONS IN THE RENIN ANGIOTENSIN SYSTEM IN RATS 


\section{ABSTRACT}

The present study was designed to characterize the regulation of the angiotensinogen $(A O)$ and renin mRNA in different tissues. Experiments were performed in 3 month-old Wistar Kyoto (WKY) rats. In the first experiment a coarctation of the abdominal aorta was made and the animals were sacrificed 7 days later. These animals exhibited significant cardiac hypertrophy. In the second experiment normal animals received the angiotensin converting enzyme inhibitor (ACE-1) captopril $(0.5$ $\mathrm{mg} / \mathrm{kg} / \mathrm{hr}$ ). In the third experiment the rats were subjected to bilateral nephrectomy or sham surgery. In the last two experiments the rats were sacrificed after 24 hours. In all experiments plasma angiotensin II (pANG II) concentrations and plasma renin activity (PRA) were measured and the tissues of interest were removed for determination of $A O$ and renin mANA expression by Northern blot hybridization. Nephrectomy significantly increased AO mRNA expression in the liver and in the brain (190\% and $160 \%$ of sham, resp.) but had no effect on AO mRNA expression in the other tissues. In contrast, both aorta coarctation and captopril treatment significantly decreased AO mRNA expression in the atria ( $25 \%$ and $83 \%$ of sham, resp.) but had no effect on AO mANA expression in liver and brain. Furthermore, we found a $67 \%$ increase of renal renin mRNA expression after captopril treatment, while none of the other tissues examined showed a difference in renin mRNA expression. Abdominal aorta coarctation and nephrectomy revealed no difference in renin mANA expression in all tissues examined. These observations are consistent with a negative feedback of renin mRNA expression by ANG II in the kidney, but not in other tissues. From these data we conclude that there is a differential regulation of $A O$ and renin mRNA in the different tissues examined: while AO mRNA in the liver and the brain appears to be tonically inhibited by renin, AO mRNA in the atria is not. Furthermore we conclude that myocardial hypertrophy is not necessarily associated with an increased AO mRNA expression.

\subsection{INTRODUCTION}

The renin-angiotensin-system (RAS) plays an important role in blood pressure and hydromineral homeostasis, with ANG $\|$ as the biologically active component of the RAS. In the classical concept (systemic RAS), the RAS is a circulating hormonal system. In addition, expression of components of the RAS has been shown in several tissues, like heart, aorta, adrenal gland, brain and kidney $(4,5,10,15,26,32)$, suggesting the existence of a local RAS. Several authors $(17,28)$ suggest the involvement of a cardiac RAS in cardiovascular disorders. For instance, increased cardiac AO mRNA and anglotensin-converting enzyme (ACE) activity and mRNA expression were found after aortic banding $(1,33)$ or myocardial infarction $(12,18,25)$.

Although local synthesis of $A O$ is a prerequisite for a local RAS, little is known about the regulation of the AO gene. The most obvious findings were obtained with 
steroids $(8,11)$ and $A N G \|(2,17,23,24,30,34)$, which upregulate the hepatic or, in case of ANG $\|$, the renal AO mANA expression of the rat (34). Effects of ANG $\|$ on AO mRNA expression were shown both at pharmacological and physiological ANG II concentrations (21). Besides ANG II, also renin has been suggested to modulate AO production. Administration of renim was associated with decreases in plasma $A O$ $(31,36)$ and liver AO levels (16). Several studies suggest that ANG II is also a potent regulator of renin synthesis $(9,13)$. ANG II-administration was shown to inhibit renal renin release and $\mathrm{MRNA}$ expression (34). Furthermore, low sodium intake has been demonstrated to increase renal renin mRNA expression, whereas ACTH and potassium increase renin mRNA expression in cultured adrenal zona glomerulosa cells (38).

The present experiments were performed to determine the regulation of $\mathrm{AO}$ MRNA and renin mRNA in different tissues by manipulating the plasma concentrations of the different components of the RAS, by nephrectomy, ACE-inhibition and aorta coarctation.

\subsection{MATERIALS AND METHODS}

\section{Surgery.}

In all experimental groups and sham-operated groups $15 \mathrm{WKY}$ rats were used (chapter 2.1). The animals were randomly assigned to the different groups. Nine rats in each group were used for determining the $A O$ and renin mRNA expression. Six rats in each group were used for determination of PANG II (chapter 2.7.1) concentrations and PRA (chapter 2.7.2). Body weight was measured before and after the experiments.

\section{Nephrectomy.}

Rats were subjected to bilateral nephrectomy as described in chapter 2.2.2. Twentyfour hours later the animals were sacrificed in deep ether anesthesia. Left and right ventricle, atria, brain, liver, kidneys and lungs were removed, frozen in liquid nitrogen and stored at $-70^{\circ} \mathrm{C}$.

\section{Abdominal aorta coarctation.}

Seven days after surgery (chapter 2.2.3) sham and coarctation animals were sacrificed in deep ether anesthesia. The atria were separated from the ventricles. The ventricles were weighed and ventricle/body weight ratlo was used as an indicator of cardiac hypertrophy. The left ventricle, right ventricle, atria, and liver were frozen in liquild nitrogen and stored at $-70^{\circ} \mathrm{C}$. 


\section{Captopril treatment.}

Twenty-four hours after captopril treatment (chapter 2.2.4) rats were sacrificed in deep ether anesthesia. Left and right ventricle, atria, brain, liver, kidneys and lungs were removed, frozen in liquid nitrogen and stored at $-70^{\circ} \mathrm{C}$.

Plasma ANG II.

The assay used for measuring the plasma ANG || concentrations are described in chapter 2.7.1

Plasma renin activity.

The assay used for measuring PRA is described in chapter 2.7.2

RNA isolation.

Because of the low amount of RNA in the atria, the atria of two or three animals in each experiment were pooled. Total RNA was extracted using the LiCl/urea method as described in chapter 2.3.2.

Northern hyoridization analysis.

In chapter 2.5 this procedure is described. The probes used in this chapter were the cDNA inserts to $A O(1634 \mathrm{~kb}), 18 \mathrm{~S}$ rFNA $(750 \mathrm{bp})$ and renin (1425 bp).

\section{Statistics.}

Data are presented as means \pm SEM and comparisons were made by MannWhitney $U$ test. Stastical significance was accepted at the level of $p<0.05$ (chapter 2.9).

\subsection{RESULTS}

$\mathrm{AO}$ and renin mRNA expression were detected at $1.8 \mathrm{~kb}$ and $1.6 \mathrm{~kb}$, respectively. AO mRNA expression was highest in the liver and renin mRNA expression was highest in the kidney. The mRNA expression of AO in the atria was very low, near the level of detection. AO mRNA levels in the ventricles were even lower and could not be cletected by the Northern hybridization analysis. Using Northern hybridization analysis renin mRNA, although present in the other tissues, could also not be detected in the compartments of the heart. 


\section{LIVER}

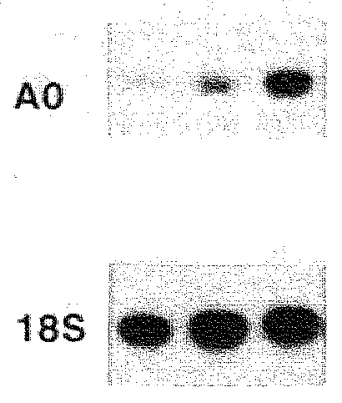

SH CA NX

\section{BRAIN}
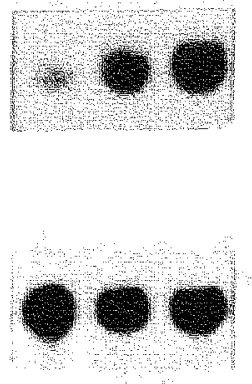

SH CA NX

Figure 1. Northern blot of rat liver and brain total RNA $(15 \mathrm{\mu g})$ hybridized with radiolabeled angiotensinogen (AO) and $13 S$ cDNA probes, 24 hours after nephrectomy (NX), or caplopril (CAP) treatment and in sham $(\mathrm{SH})$ rats.

\section{Angiotensinogen mRNA expression}

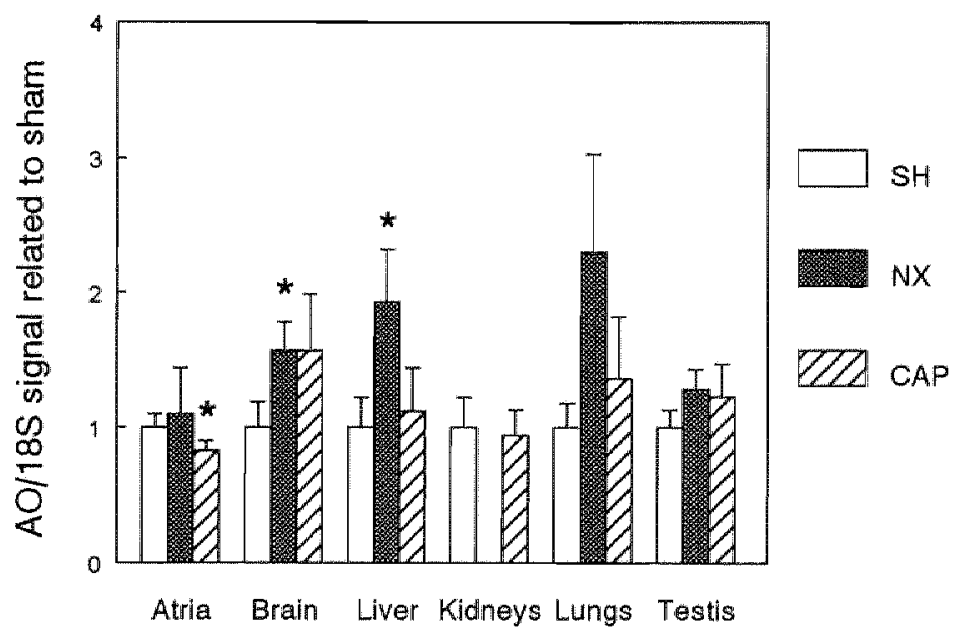

Figure 2. Densitometric analysis of messenger RNA levels for angiotensinogen in atria, brain, liwer, kidneys, lungs, testis in sham (SH) rats, 24 hours after nephrectomy $(N X)$, or captopril treatment (CAP). All values are normalized to the densitometric angiotensinogen $(A O) / 18 S$ ratio of the sham rat. $P<0.05$, significantly different from sham. 
Nephrectomy.

Twenty-four hours after bilateral nephrectomy we observed a 1.9 fold increase of liver $(n=9)$ and a 1.6 fold increase of brain AO mANA $(n=6 \text {; figures } 1 \text { and } 2)_{,}$the two major organs for $A O$ production, when compared to the sham animals. In all the other tissues examined, no difference in AO mRNA expression was found between the sham and nephrectomized animals (figure 2). Renin mRNA expression was not affected in any of the tissues examined.

\section{Abdominal aorta coarctation.}

Seven days after abdominal aorta coarctation a significant increase $(9.1 \pm 0.9 \%)$ in the ventricle/body weight ratio was observed in the coarctation animals when compared to the sham animals. No change in body welght was seen after surgery in both groups, indicating that the increase in the ventricle/body weight ratio was due to hypertrophy of the ventricles. AO mRNA expression in the atria was significantly decreased after aorta coarctation ( $25 \%$ of sham, $n=3$; figure 3 ). AO mRNA expression in the liver was not different in abidominal aorta coarctation versus sham (figure 3). Aorta coarctation did not affect renin mRNA expression in all tissues examined.

\section{Captopril treatment.}

After 24 hours of captopril treatment AO mRNA expression in the atria was significantly decreased when compared to the sham animals ( $83 \%$ of sham, $n=3$ ). None of the other tissues examined, showed a difference in AO mRNA expression after captopril treatment (figure 2). Renal renin mRNA (figure 4) expression was significantly increased by captopril treatment $(1.7$ fold, $n=6)$, while no effect on renin mRNA expression was observed in the other tissues.

\section{PAA and PANG /I}

In table 1 PRA and PANG II levels are shown after the different interventions. After nephrectomy PANG II decreased to $10 \%$ of sham-operalted rats, whereas PRA was not detectable in the experimental group. After 7 days of abdominal aorta coarctation there was no increase in PANG $\|$ as well as PRA, when compared with the sham-operated animals. After captopril treatment pANG II was $45 \%$ of shamoperated rats, while there was an 8-fold increase in PRA compared to sham group. 


\section{Angiotensinogen mRNA expression}

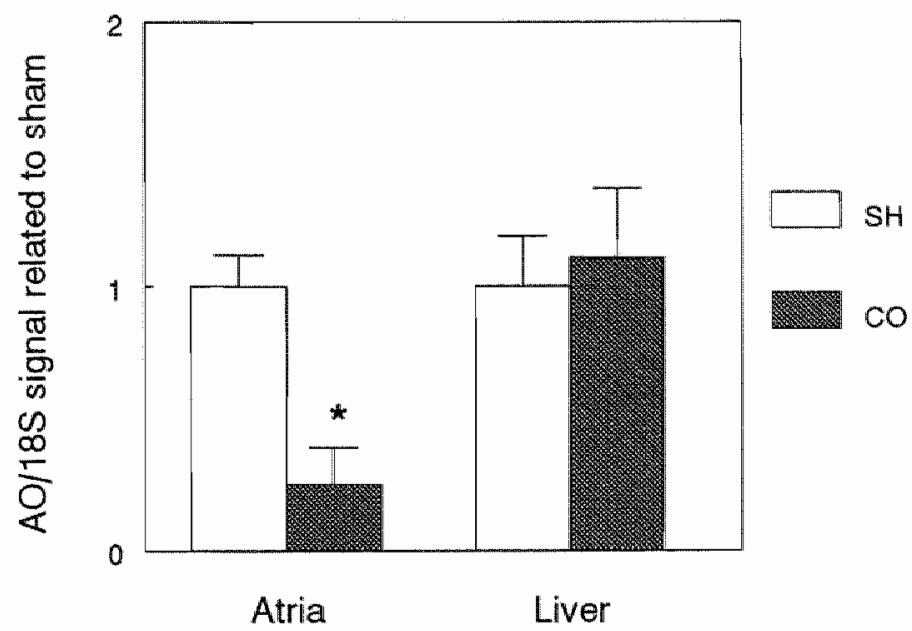

Figure 3. Densitometric analysis of messenger RNA levels for angiotensinogen mRNA in atria and * liver, 7 days after abdominal aorta coarctation (CO). All values are normalized to the densitometric: angiotensinogen $(\mathrm{AO}) / 18 \mathrm{~S}$ ratio of the sham $(\mathrm{SH})$ rat. ${ }^{*} \mathrm{P}<0.05$, significantly different from sham.

\section{Renal renin mRNA levels}

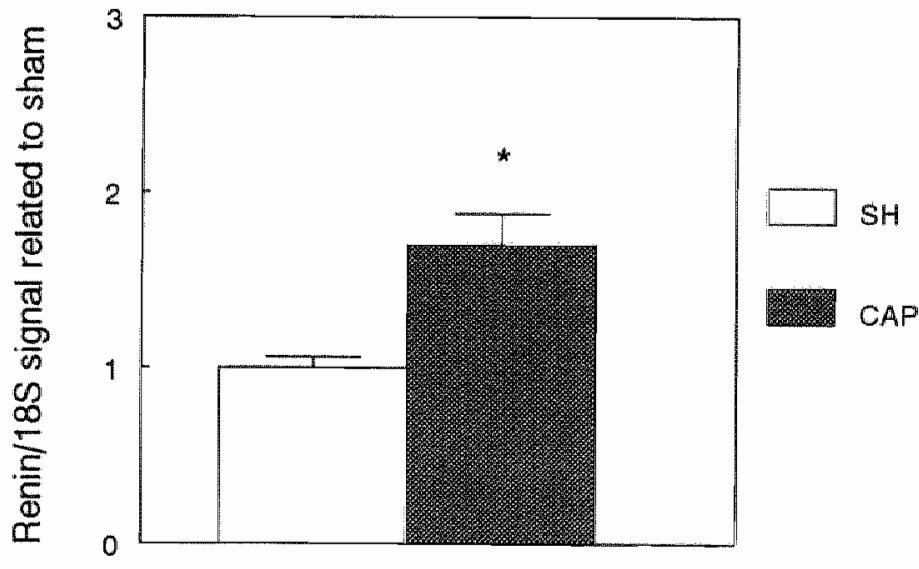

Figure 4. Densitometric analysis of messenger RNA levels for renin in the kidney in sham (SH) and captopril (CAP) treated animals. All values are normalized to the densitometric renin/18S ratio of the sham rat. " $P<0.05$, significantly different from sham. 
Table 1: Plasma renin activity and plasma ANG II following aorta coarctation. nephrectomy or captopril treatment

\begin{tabular}{c|cc|ccc}
\hline & SH & CO & SH & NX & CAP \\
\hline PRA & $31 \pm 6.1$ & $26 \pm 15$ & $28 \pm 7.0$ & N.D. & $223 \pm 62^{*}$ \\
PANG II & $38 \pm 8.2$ & $35 \pm 13$ & $38 \pm 4.4$ & $3.9 \pm 0.31^{*}$ & $17 \pm 3.6^{*}$ \\
\hline
\end{tabular}

$\mathrm{SH}=$ sham; $\mathrm{CO}=$ aorta coarctation; $N \mathrm{NX}=$ nephrectomy; $\mathrm{CAP}=$ captopril treatment; $\mathrm{PRA}=$ plasma renin activity; $\mathrm{pANG} \|=$ plasma $A N G \|$ levels: N.D. $=$ not detectable; "ps 0.05

\subsection{DISCUSSION}

The present study was designed to analyze the regulation of $A O$ and renin mRNA expression in several tissues of the rat, by experimentally manipulating the different components of the RAS. The data of our study are summarlized in table 2. Little is known about the regulation of $\mathrm{AO}$ and renin mRNA expression. Increased $\mathrm{AO}$ mRNA synthesis was found following glucocorticoid administration to rats (22), a rat hepatoma cell line (8), or fat cells (5). In a study in intact rats "Campbell and Habener (4) did not observe any regional specifity, but rather an overall increase in all tissues examined. In contrast, androgens may differentially affect tissues, since testosterone administration to femalle or castrated male rats increases renal but not hepatic AO mRNA expression (11). Different factors have also been reported to regulate renin mRNA expression in the kidney. Sodium deprivation has been demonstrated to increase renal renin $\mathrm{mRNA}$ expression $(7,20,39)$. In addition an upregulation of renin mRNA was also found in cultured adrenal zona glomerulosa cells by ACTH and potassium (38).

In addition also the components of the RAS have been suggested to modulate $A O$ and renin mRNA expression. Both renin and ANG II themselves were demonstrated to influence hepatic production or plasma levels of AO. Administration of ANG II increases hepatic $(30,34)$ and renal (34) AO mRNA expression in vivo and also increases hepatic $\mathrm{AO}$ protein synthesis in vivo $(23,31)$ and in vitro $(16,24)$, indicating the existence of a positive feedback of ANG II on the production of AO. AS mentioned above, also renin has been shown to modulate $A O$, since administration of renin decreases plasma levels $(31,36)$ and liver concentrations (16) of $A O$, indicating the negative feedback of renin on AO production. ANG II has also been found to regulate renin mRNA expression and production. ANG II administration exerted a negative feedback on renal renin mRNA expression and renin release $(29,34)$. This was confirmed by studies performed with the ANG I-antagonist Dup753 (40) or captopril $(19,27)$, which revealed an increase in plasma renin concentrations and renal renin mRNA expression. 
Table 2. Effects of nephrectomy, aorta coarctation and captopril Ireatment on systemic RAS or intracardiac angiotensinogen and renin.

\begin{tabular}{|c|c|c|c|c|c|c|c|c|c|c|}
\hline & \multicolumn{2}{|c|}{ Llver } & \multicolumn{2}{|c|}{ Braln } & \multicolumn{2}{|c|}{ Atria } & \multicolumn{2}{|c|}{ KIdvey } \\
\hline & & & AO & renin & AO & reniln & AO & renin & $\mathrm{AO}$ & renin \\
\hline & ING & PRA & & & & & & & & \\
\hline$N X^{\prime \prime}$ & 11 & $\downarrow \downarrow$ & $\uparrow$ & $\leftrightarrow$ & $\uparrow$ & $\leftrightarrow$ & $\leftrightarrow$ & $\leftrightarrow$ & & \\
\hline CAP & $\downarrow$ & $\uparrow \uparrow$ & $\leftrightarrow$ & $\leftrightarrow$ & $\leftrightarrow$ & $\leftrightarrow$ & $\downarrow$ & $\leftrightarrow$ & $+*$ & $\uparrow$ \\
\hline $\mathrm{CO}$ & $\leftrightarrow$ & $\Leftrightarrow$ & $\leftrightarrow$ & $\leftrightarrow$ & & $\leftrightarrow$ & $\downarrow$ & $\leftrightarrow$ & $\leftrightarrow$ & $\leftrightarrow$ \\
\hline
\end{tabular}

$N X=$ nephrectomy (24 hours); $C O=$ aorta coarctation (7 dlays); CAP = captopril treatment (24 hours); $A O=$ angiotensinogen; $P A N G \|$ mlasma angiotensin $\|$ levels; PRA $=$ plasma renin activity; $\dagger=$ increase; 1 - decrease; $\rightarrow$ mo change.

In the present study we observed an increase of hepatic and brain AO mRNA following nephrectomy. None of the other tissues examined showed a difference in AO mRNA expression following nephrectomy. These observations are in accordance with a tonic inhibition of hepatic and brain AO production by renin, since nephrectomy is associated with both plasma renin and ANG II were extremely low (table 1). Similar observations were previously made by Campbell and Habener (4). Nephrectomy did not result in differences in renin mRNA expression in the different tissues examined.

Aorta coarctation as employed in the present study (i.e. similar to two-kidney one-clip hypertension) induced ventricular hypertrophy, but did not result in increased PRA and ANG II plasma levels. At least after 7 days of coarctation PRA and pANG II were not different from sham-operated rats, although abdominal aorta coarctation initially leads to an increase of these parameters (28), indicating the dynamics of the RAS. In our study AO mRNA expression was decreased in the atria, following coarctation. None of the other tissues showed a difference in AO mRNA expression. The effect differs from the increase of AO mRNA expression in the atria, reported by Baker et al. (1); in their model, however, they ligated the aorta above the renal bifurcation, which resulted in a volume dependent hypertension model (similar to one-kidney one-clip). These authors, in their model of coarctation (vide supra) observed increased AO mRNA in atria after fifteen days. They also noted normal plasma renin concentration, and presumed normal ANG II levels. However they could not detect a difference in atrial AO mRNA expression after 7 days after aorta coarctation. This emphasizes the dynamics and the variability of the RAS in time. In this model no difference in renin mANA expression was detected in all tissues examined.

Treatment with converting enzyme inhibitors has yielded more variable results with respect to hepatic AO mRNA levels. Long-term administration in rats has been shown to result in increased (1) or unchanged $(6,14,34)$ AO mRNA expression in 
liver. In at least two other studies, reductions were noted as soon as 4 hours after administration $(21,30)$. In the present study, 24 hours infusion of captoprill resulted in a decrease of atrial AO mRNA but did not affect $A O$ mRNA levels in the other tissues examined. This discrepancy in the different studies may depend upon the dynamics of the responses of renin and ANG II to ACE inhibitors. In our study 24 hours after captopril treatment, circulating ANG || levels are reduced, whereas renin levels are increased (table 1). However during chronic treatment ANG II levels return to normal (3), while renin levels remain increased. Thus, depending upon the duration of administration and the dosage-interval the balance of the effects of renin and ANG II may differ. Baker et al (1) administered enalapril for 1 to 2 weeks and noted increased left ventricular AO mRNA levels. Again, this may depend upon the dynamics of the response to the drugs (vide supra) and the duration of administration. The increased PRA in our study may be responsible for the decreased AO MANA expression in the atria by a negative feedback. The hypothesis that a tonic inhibition (vide supra) in non-atrial tissues, like liver and brain, plays a role in the regulation of $A O$ mRNA expression, is strengthened by the lack of difference in AO mRNA expression in those tissues.

Renal renin mRNA expression was increased after captopril treatment. This is in accordance with the increase in plasma renin concentrations and renal renin mRNA expression after treatment with an ANG II-antagonist or captopril $(19,27)$. Our data confirm that ANG $\|$ is an important factor in controlling renal renin mRNA expression. Renin mRNA expression was not different in the extrarenal tissues examined. Studies on the regulation of extrarenal renin mRNA expression are scarce. In a study by Iwal \& Inagami (19) renin mRNA expression levels in the brain increased during 7 day administration of captopril. In the present study there was no increase in brain renin mANA. However the captopril treatment in our study lasted only 24 hours and the captopril dose was 8 times lower, although this dose causes a 17-fold

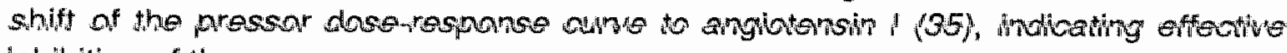
Inhibition of the enzyme.

The present study provides further evidence for the differential regulation of local AO and renin mRNA expression in different tissues by components of the RAS. The brain RAS has been implied in cardiovascular control and has been shown to be regulated independently from the circulating system (37). Our results and those of others (4) suggest that this is not the case for the feedback regulation by the components of the system, although we have not addressed the influence of physiological stimull as low or high sodium intake. The cardiac RAS has been implied in cardiac hypertrophy. In the present study, aortic coarctation was found to be assoclated with ventricular hypertrophy. This was associated with decreased atrial expression of AO mRNA in the present study, but increased expression in another (1). This suggests that cardiac hypertrophy is not necessarily associated with increased AO mRNA expression.

In conclusion, we observed differential expression and regulation of expression of $A O$ and renin mRNA in different tissues of the rat. In liver and brain, and possibly 
also in the atria AO mRNA expression seems to be controlled by both renin and ANG $\| 1$ levels in plasma. The dynamics of the RAS and the differential responses of the different tissues make it difficult to predict the regulation of their genes at a certain time point. The balance between the two hormones deterimines the outcome for expression. Furthermore, we show that hypertrophy is not necessarily associated with increased cardiac expression of $\mathrm{AO}$.

\section{REFERENCES}

1. Baker KM, Chernin MI, Wixson SK, Aceto JF. Renin-angiotensin system involvernent in pressureowerload cardiac hypertrophy in rats. Am J Physiol 1990; 259:H324-H332.

2. Ben-Ari ET, Garrison JC. Regulation of angiotensinogen mRNA accumulation in rat hepatocytes. Am J Physial 1988; 255:E70-E79.

3. Bunkenburg B, Schnell C, Baum HP. Cumin F, Wood JM. Prolonged angiotensin II antagonism in spontaneously hypertensive rats. Hemodynamic and biochemical consequences. Hypertension 1991; 18:278-288.

4. Campbell DJ, Habener JF. Angiotensinogen gene is expressed and differentially regulated in multiple tissues of the rat. 1 Clin Invest 1986; 78:31 139.

5. Campbell DJ, Habener JF. Cellular localization of angiotensinogen gene expression in brown adipose tissue and mesentery: quantification of messenger ribonucleic acid abundance using lhybridization in situ. Endocrinology 1987; 121:1616-1626.

6. Campbell DJ, Lawrence AC, Towrie A, Kladis A, Valentijn AJ. Differential regulation of angiotensin peptide levels in plasma and kidney of the rat. Hypertension $1991 ; 18: 763-773$.

7. Chai SY, Allen AM, Adam WR, Mendelsohn FA. Local actions of angiotensin II: quantitative in vitro autoradiographic localization of angiotensin II receptor binding and angiotensin converting enzyme in target tissues. J Cardiovasc Pharmacol 1986; 8 (Suppl. 10):S35-\$39.

B. Chang E. Perlman AJ. Multiple hormones regulate angiotensinogen messenger ribonucleic acid levels in a rat hepatoma cell line. Endocrinology 1987; 121:513-519.

9. Davis JO, Freeman $\mathrm{RH}$. Mechanisms regulating renin release. Physiol Rew 1976; 56:1-56.

10. Dzau WJ. Vascular renin-angiotensin: a possible autocrine or paracrine system in control of vascular function. J Cardiovasc Pharmacol 1984; 6:S377-S382.

11. Ellison KE, Ingelfinger JR, Pivor M, Dzau WJ. Androgen regulation of rat renal angiotensinogen messenger ANA expression. J Clin Invest 1989; B3:1941-1945.

12. Fabris $B$, Jackson $B$, Kohzuki $M$, Perilch $A$, Johnston $C$. Increased cardiac angiotensin-conventing enzyme in rats with chronic heart failure. Cin Exp Pharmacol Physiol 1990; 17:309-314.

13. Gibbons GH, Dzau WJ. Farhi ER. Interaction of sinals influencing renin release. Annual Reviews of Physiology 1984; 46:291-308.

14. Gomez RA, Lynch KR, Chevalier RL, Everett AD, Johns DW, Wilfong N, Peach MJ, Carey RM. Renin and angiotensinogen gene expression and intrarenal renin distribution during $A C E$ inhibition. Am J Phystiol 1988; 254:F900-F906.

15. Hellmann W, Suzuki $F$, Ohkubo $H$, Nakanishi $S$, Ludwig G, Ganten D. Angiotensinogen gene expression in extrahepatic rat tissues: application of a solution hyloridization assay. Naunyn Schmiedebergs Arch Pharmacol 1988; 338:327-331.

16. Herrmann HC, Dzau VJ. The feedback regulation of angiotensinogen production. Circ Res 1983; $52: 328$. 
17. Herrmann HC, Morris B., Reid IA. Effect of angiotensin II and sodium depletion on angiotensinogen production. Am J Physiol 1980; 238:E145-E149.

18. Hirsch AT, Talsness CE, Schunkert H, Paul M, Dzau WJ. Tissue-specific activation of cardiac angiotensin converting enzyme in experimental heart failure. Circ Res 1991;69:475-482.

19. Iwai $\mathbb{N}$, Inagami $\mathbb{T}$. Quantitative analysis of renin gene expression in extrarenal tissues by polymerase chain reaction method. $J$ Hypertens 1992; 10:717-724.

20. Iwao $H$, Fukui $K, K$ im $S$. Effect of changes in sodium balance on renin, angiotensinogen and atrial natriuretic factor messenger RNA levels in ratt. I Hypertens Suppl 1988; 6:S297-S299.

21. Wwo H, Nakamura A, Fukui $K$, Kimura $S$, Tamaki $T$, Abe $Y$. Endogenous angiotensin II regulates hepatic angiotensinogen production. Life Soi 1990; 47:2343-2349.

22. Kalinyak JE, Perlman Ad. Tissue-specific regulation of angiotensinogen mANA accumulation by dexamethasone. J Biol Chem 1987; 262:460-464.

23. Khayyall M, MacGregor J, Brown JJ, Lever AF, Robertson JIS. Increase of plasma reninsubstrate concentration after infusion of angiotensin in the rat. Clin Sci 1973; 44:87-90.

24. Klett $C_{*}$ Hackenthal $E$. Induction of angitatensinogen synthesis and secretion by angiotensin II. Clin Exp Hypertens A 1987; A9(12):2027-2047.

25. Lindpaintner $K$, Lu W. Neidermaier $N$. Schieffer $B$, Just $H$, Ganten D, Drexler $H$. Selective activation of cardiac angiotensinogen gene expression in post-infarction ventricular remodeling in the rat. $J$ Mol Cell Cardiol $1993 ; 25: 133-143$.

26. Lindpaintner $K_{n}$ Wilhelm $M J$, Jin $M$, Unger $T$, Lang RE, Scholkens BA, Ganten D. Tissiue renin angiotensin systems: focus on the heart. J Hypertens Suppl 1987; 5:S33-S38.

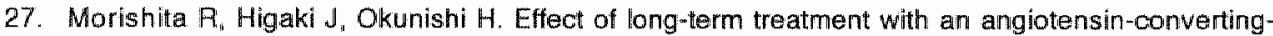
enzyme inhibitor on the renin-angiotensin system in spontaneously hypertensive rats. Clin Exp Pharmacol Physiol 1991; 18:685-690.

28. Morton $\mathrm{JJ}$, Wallace ECH. The importance of the renin-angiotensin system in the development and maintenance of hypertension in the two-kidney one-dip hypertensive rat. Clin Sci 1983; 64:359370 .

29. Naftilan AJ "Oparil S. Inhibition of renin release from rat kidney slices by the angiotensins. Am $J$ Physiol 1978; 235:F62-F68.

30. Nakamura $A$, Iwao $H$, Fukui $K$, Kimura $S$, Tamaki $T$, Nakanishi $S$, Abe $Y$. Regulation of liver angiotensiniogen and kidney renin mRNA levels by angiotensin II. Am J Physiol 1990; 258:E1-E6.

31. Nasjletti $A$. Masson GMC. Stimulation of angiotensinogen formation by renin and angiotensin. Proc Soc Exp Biol Med 1973; 142:307-310.

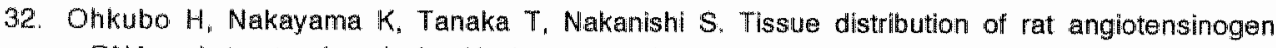
MANA and structural analysis of its heterogeneity. J Biol Chem 1986; 261:319-323.

33. Schunkert $H_{4}$ Dzau VJ, Tang SS, Hirsch AT, Apstein CS, Lorell BH. lincreased rat cardiac angiotensin converting enzyme activity and mRNA expression in pressure overload left ventricular hypertrophy. Effects on coronary resistance, contractility, and relaxation. . Clin Invest 1990; 86:1913-1920.

34. Schunkert $H$, lngelfinger $J \mathbb{P}$, Jacob $H$, Jackson $B$, Bauyounes $B$, Dzau VJ. Reciprocal feedback regulation of kidney angiotensinogen and renin mRNA expressions by angiotensin II. Am $\mathrm{J}$ Physial 1992; 263:E863-E869.

35. Smits JF, van-Krimpen C, Schoemaker RG, Cleutjens JP, Daemen MJ. Angiotensin II receptor blockade after myocardial infarction in rats: effects on hemodynamics, myocardial DNA synthesis, and interstitial collagen content. J Cardiovasc Pharmacol 1992; 20:772-778.

36. Tateishi $\mathrm{H}, \mathrm{Nasjletti} A$, Masson GMC. Role of renin in the regulation of angiotensinagen levels in plasma. Proc Sac Exp Biol Med 1971; 137:1424-1428. 
37. Unger T, Kaufmann-Buhler I, Scholkens B, Ganten D. Brain converting enzyme inhibition: a possible mechanism for the antihypertensive action in captopril in spontaneously hypentensive rats. Eur J Pharmacol 1981; 70:467-472.

38. Wang $Y$, Yamaguchi T. Franco-Saenz R, Mulrow PJ. Regulation of renin gene expression in rat adrenal zona glomerulosa cells. Hypertension 1992; 20:776-781.

39. Welsch $C$, Grima M, Giesen EM, Helwig JJ, Barthellmebs $M$, Coquard $C$, Imbs JL. Assay of tissue angiotensin converting enzyme. $J$ Cardiowasc Pharmacol 1989; 14 Suppl 4:S26-S31.

40. Zhuo $\mathrm{J}$, Thomas $\mathrm{D}$, Harris $\mathrm{PJ}$. The role of endogenous angiotensin II in the regulation of renal haemodynamics and proximal fluid reabsorption in the rat. Am J Physiol 1992; 453:1-13. 


\section{CHAPTER 4}

ACTIVATION OF ANGIOTENSIN I-CONVERTING-ENZYME GENE AND PROTEIN IN THE INFARCT ZONE FOLLOWING MYOCARDIAL INFARCTION IN THE RAT 


\section{ABSTRACT}

In the present study we quantified angiotensin l-converting enzyme (ACE) mRNA and localized ACE mRNA and protein in the infarcted rat heart. Wistar rats underwent ligation of the left descending coronary artery, resulting in myocardial infarction (MI), or a sham-operation. At different times (1-90 days) after surgery ( $n=3$ each) the heart was removed and divided into right ventricle (RV), septum (SE) and left ventricle (LV). ACE mANA was quantified by competitive reverse transcriptase polymerase chain reaction (RT-PCR). At 4 and 7 days after MI we found a 2.8 -fold respectively 2.7 -fold increase of $A C E$ mRNA $(n=3 ; p<0.05)$ in the infarcted LV compared to the LV of the sham-group. No increases of ACE mRNA were found in the non-infarcted hypertrophied compartments. ACE activity increased 2.6-fold and 3.6-fold in the infarcted $L V$ at 7 and 90 days after $M I$, respectively. In situ hybridization and immunohistochemistry showed increased ACE mRNA and protein density in the border zone of the infarct area, predominantly in the endothelial cells lining capillaries. In the non-infarcted myocardium ACE MRNA and protein were confined to endothelial cells of the larger vessels. From these data we conclude that the intracardiac ACE is not necessarily associated with hypertrophy in the rat heart after MI. Furthermore, the data suggest that the intracardiac ACE is involved in the healing of the scar after $\mathrm{Ml}$ in the rat, possibly giving rise to neovascularization and/or fibrosis.

\subsection{INTRODUCTION}

Angiotensinogen, $A C E$, and angiotensin $\|$ receptors have all been detected at the mRNA and protein levels in the heart, indicating local synthesis of these components $(11,23)$. The intracardiac RAS is thought to be involved in the development of cardiac hypertrophy since angiotensin II (ANG II) itself is a stimulus for growth. In vitro, ANG II induces not only the mRNA expression of the protooncogenes c-fos, c-myc and c-jun in vascular smooth muscle cells $(28,42)$, cardiac myocytes and cardiac fibroblasts (33), but also hypertrophy and/or hyperplasia of these cells $(2,4,8,33)$. In experimental $\mathrm{MI}$ in the rat, which induces cardiac hypertrophy (1), increased angiotensinogen mRNA levels were found in the noninfarcted LV (24). Increased ACE MRNA and activity $(13,17)$ were found in all compartments of the heart after MI. Also in humans an increased ACE mRNA expression was found after MI (38). Increased cardiac ACE mRNA and enzymeactivity were also demonstrated in another model of cardiac hypertrophy, i.e. aortic stenosis (34). In accordance with a functional role for ACE in hypertrophy are the observations that even a non-hypotensive dose of an ACE-inhibitor (ACE-l) regresses cardiac hypertrophy (25).

Since the localization of ACE protein in the heart is closely related to myocardial fibrosis induced by chronic aldosterone and/or ANG II treatment (40), it has also been suggested that the intracardiac RAS plays a role in wound healing and fibrosis. 
This is supported by the findings of increased ACE immunoreactivity in the infarct area in human and rat hearts $(9,14)$.

Although there is some evidence available for the role of ACE in cardiac hypertrophy and wound healing, quantitative data combined with ACE localization are lacking. In the present study we quantified ACE MRNA expression with the highly sensitive competitive RT-PCR and localized ACE MRNA and its protein by in situ hybridization and immunohistochemistry, respectively, at different times after MI, a model for studying the development of hypertrophy and wound healing. We found an increase in ACE mRNA expression in the infarcted LV in the early phase after MI, but no increase in the hypertrophied non-infarcted myocardium. ACE IRANA and protein were predominantly localized in the border zone of the infarct area and in the endothelial cells of the larger vessels in the non-infarcted myocardium.

\subsection{MATERIALS AND METHODS}

\section{Surgery}

Adult male Wistar rats were used, weighing 250-300 $\mathrm{g}$ at the beginning of the experiments. Rats underwent induction of MI (chapter 2.2.1) or sham-surgery. At 1 , $2,4,7,14$, or 90 days after surgery infarct and sham rats ( $=3$ per time point per group) were killed by ether overdose. In a second series of experiments, animals (n=3 per group) underwent the same surgery as described above. Since the highest ACE MRNA amounts were found at 4 days after MI, this time point was chosen for in situ hybridization and immunohistochemistry. In a third series of experiments, MH and sham animals ( $n=6$ per group) were sacrificed at 7 and 90 days after surgery by ether overdose for determination of cardiac ACE activity.

\section{Tissue processing}

In the first and third series of experiments the hearts were removed and a slice of tissue parallel to the base was cut, formalin fixed overnight and paraffin embedded for determination of the infarct size (chapter 2.3.1). The rest of each heart was divided in infarcted or non-infarcted (sham) LV, SE and RV. These latter tissues were subsequently frozen in liquid nitrogen and stored at $-70^{\circ} \mathrm{C}$ for RNA isolation and tissue ACE activity determination.

In the second series of experiments, the hearts of the MI or sham-operated animals were removed and cut in 2 parts parallel to the base and a slice of tissue was taken parallel to the base. All parts were formalin fixed overnight and paraffin embedded for determination of infarct size (chapter 2.3.1), in situ hybridization (chapter 2.6) and immunohistochemistry (chapter 2.8). 
ANA ISolation

Total RNA was extracted using the LIClurea method (35) as described in chapter 2.3.2.

\section{Competitive RT-PCA for ACE}

The competitive RT-PCR was used for quantifying ACE mRNA. The selection of the ACE primers, creation of the internal standard, the reverse transcription and the PCR is described in chapter 2.4. The PCR-cycle used for ACE was 0.5 min. at $94^{\circ} \mathrm{C}, 0.5 \mathrm{~min}$. at $65^{\circ} \mathrm{C}, 1 \mathrm{~min}$. at $72^{\circ} \mathrm{C}, 30$ cycles.

\section{In situ hybridization}

The rat $A C E$ PCA fragment of $389 \mathrm{bp}$, described in chapter 2.4.1, was ligated in a TA-vector. A ${ }^{33} \mathrm{P}$-UTP-labeled antisense riboprobe was created by transcription using T7 RNA polymerase (Promega). Sections of $4 \mu \mathrm{m}$, formalin fixed, paraffin embedded hearts were used for the in situ hybridization as described in chapter 2.6.

Immunohistochemistry of $A C E$

The paraffin embedded hearts from the sham group and infarct group were stained with 1:1000 dilution of the ACE antibody (goat/anti-rabbit//ung, polyclonal, gift of Dr. Soffer) as described in chapter 2.8 .

ACE activity

Tissue ACE activity was determined (chapter 2.7.3) in LV, SE and RV in sham and infarcted animals at 7 and 90 days after surgery ( $n=6$ per group).

Statlstical analysis

All data are presented as mean \pm SEM. Statistical significance was calculated using the ANOVA and Bonferroni's t-test. Statistical significance was accepted at the levell of $p<0.05$ (chapter 2.9). 


\section{0 ng TOTAL RNA}

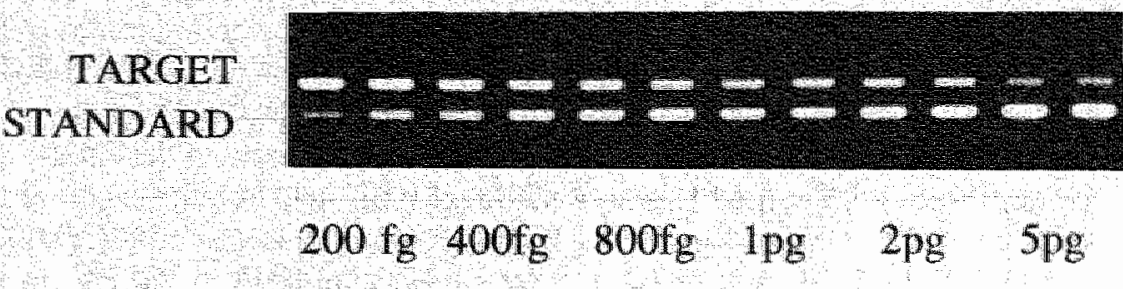

Figure 1A. Gel electrophoresis of the PCR products after competitive RT-PCA of ACE performed in duplicate, showing the target DNA ( $389 \mathrm{bp}$ ) and the standard DNA (291 bp). A constant amount of 500 ng total RNA was used together with increasing amounts of standard RNA (200fg-5pg).

\section{Competitive PCR of ACE}

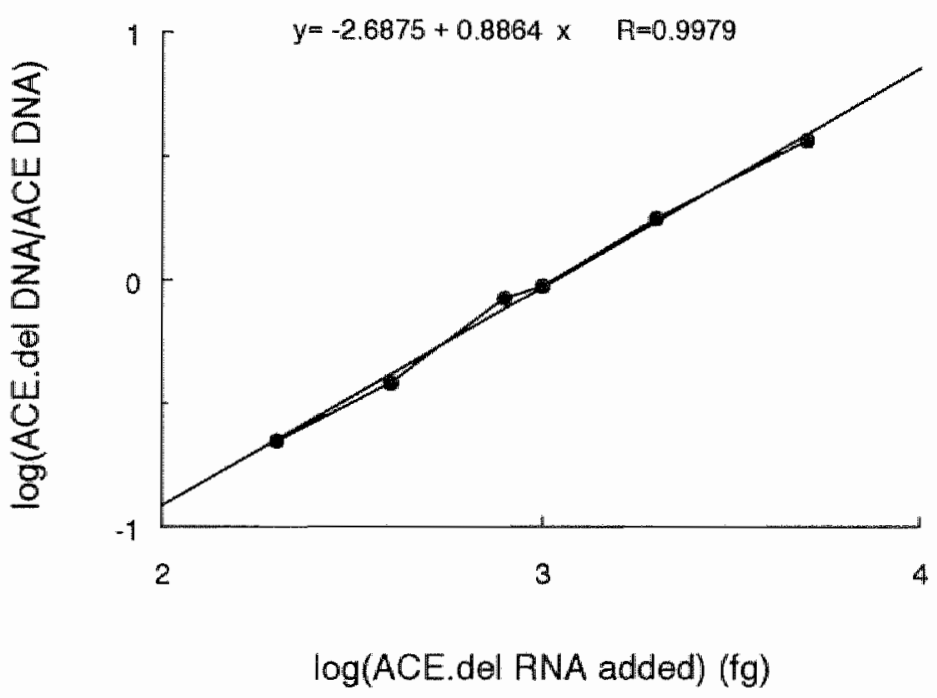

Figure 1B. Competitive RT-PCR of ACE. The logarithmic value of the standard (deledeletion) DNA/target DNA ratio after densitometry of duplicate experiments are given on the $y$-axis. The logarithmic walue of the starting amount of internal standard RNA is given on the $x$-axis. The correlation coefficient and the line of best fit are shown. By intrapolation of 0-value, the equivalence point at the $y$ axis, original ACE MRNA is calculated. 


\subsection{RESULTS}

\section{Competitive AT.PCA of ACE after MI}

Electrophoresis of the PCR products demonstrated the expected two fragments of 389 (target fragment) and $291 \mathrm{bp}$ of llength (internal standard) (figure 1A). The mean of the duplicate logarithmic ratios of the sample were plotted to the logarithm of the amount of standard RNA and the linear correlation coefficient (r) was calculated (figure 1B). If $r^{2}$ was below 0.95 data were discarded. ACE mANA expression could easily be detected by the competitive RT-PCR in each RNA sample of the heart.

In sham-operated rats the mean value (ISEM) of ACE MRNA expression at the different time points after surgery was $439 \pm 54 \mathrm{fg} / 100 \mathrm{ng}$ total RNA in the LV, $403 \pm$ $98 \mathrm{fg} / 100 \mathrm{ng}$ total RNA in SE and $547 \pm 113 \mathrm{fg} / 100 \mathrm{ng}$ total RNA in the RV. In the sham group, there was no significant difference in ACE mRNA expression at the different time points after surgery. At 4 days after MI ACE MRNA expression increased 2.8-fold in the infarcted LV compared to the non-infarcted LV in the sham group at that time point. ACE MRNA expression remained increased (2.7-fold) at 7 days after MI in the LV. Thereafter, ACE mRNA expression in the infarcted LV returned to base line values (figure 2A), and was no longer significantly different from the values obtained in the sham group. In the MI animals no significant change in ACE MRNA expression was observed in the SE and RV (figure $2 B$ and $C$, respectively) at the different time points.

\section{In situ hybridization}

At 4 days post-MI, the ${ }^{33} \mathrm{P}$ labeled rat $\mathrm{ACE}$ riboprobe showed a dense labeling in the infarct area. ACE mRNA was localized predominantly in endothelial cells lining capillaries in the border zone of the infarct area (figure $3 A$ and $B$ ). In the noninfarcted area, ACE MRNA was found in endothelial cells of the larger vessels as well as a low expression in adventitial cells (figure $3 \mathrm{C}$ ). Expression was also present in the epicardial and endocardial layer. In sham animals ACE was restricted to the endothelial cells of the larger vessels. Control experiments, performed by sense hybridization, revealled no specific labeling (data not shown).

\section{Immunohistochemistry}

Immunohistochemistry of ACE revealed the same pattern as observed when compared to the localization of the ACE mANA obtained by in situ hybridization, meaning an increased ACE-immunoreactivity in the border zone of the infarct (figure $4 A$ and $B$ ). Again ACE-immunoreactivity was predominantly found in endothelial cells. In the non-infarcted myocardium ACE immunoreactivity was observed in the pericardial and endocardial layer and in endothelial cells of large but not small vessels (figure 4C). In sham animals the same pattern was observed as in the non- 
Left ventricle

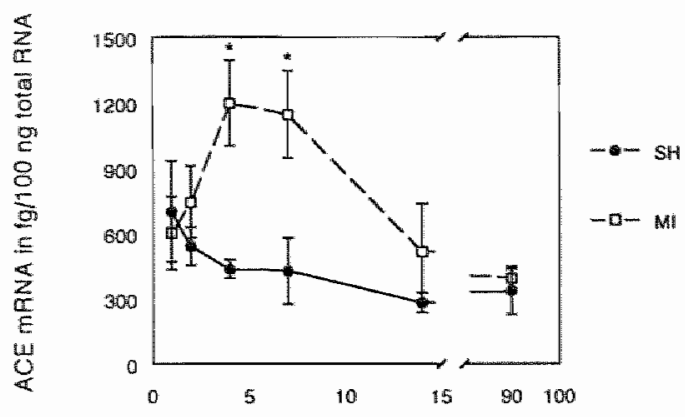

Days after surgary

Septum

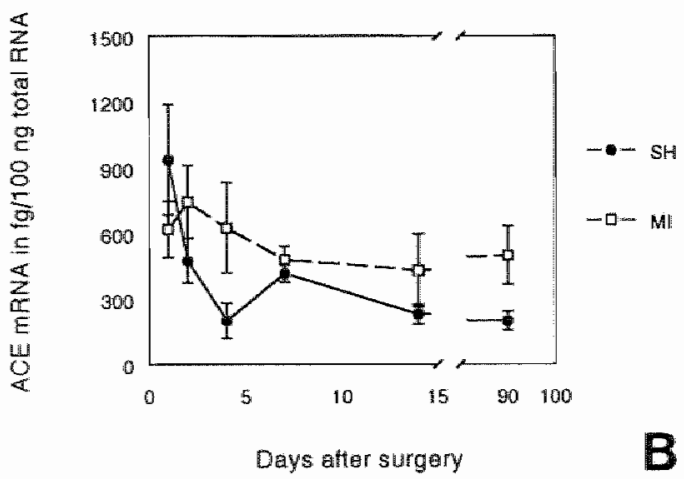

Right wentricle

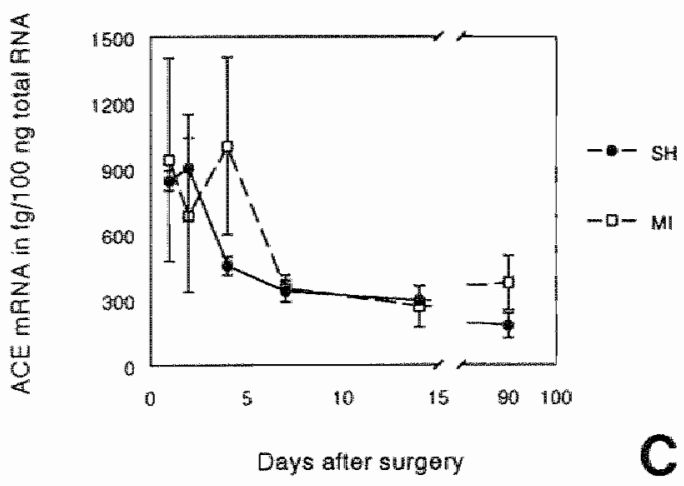

Figure 2. Time course of $\mathrm{ACE}$ mPNA amount in infarcted (MI) or sham (SH) operated rats in left ventricle $(A)$, septum $(B)$ and right ventricle (C)." $P$ values $<0.05$, signi ficantly different trom sham. 

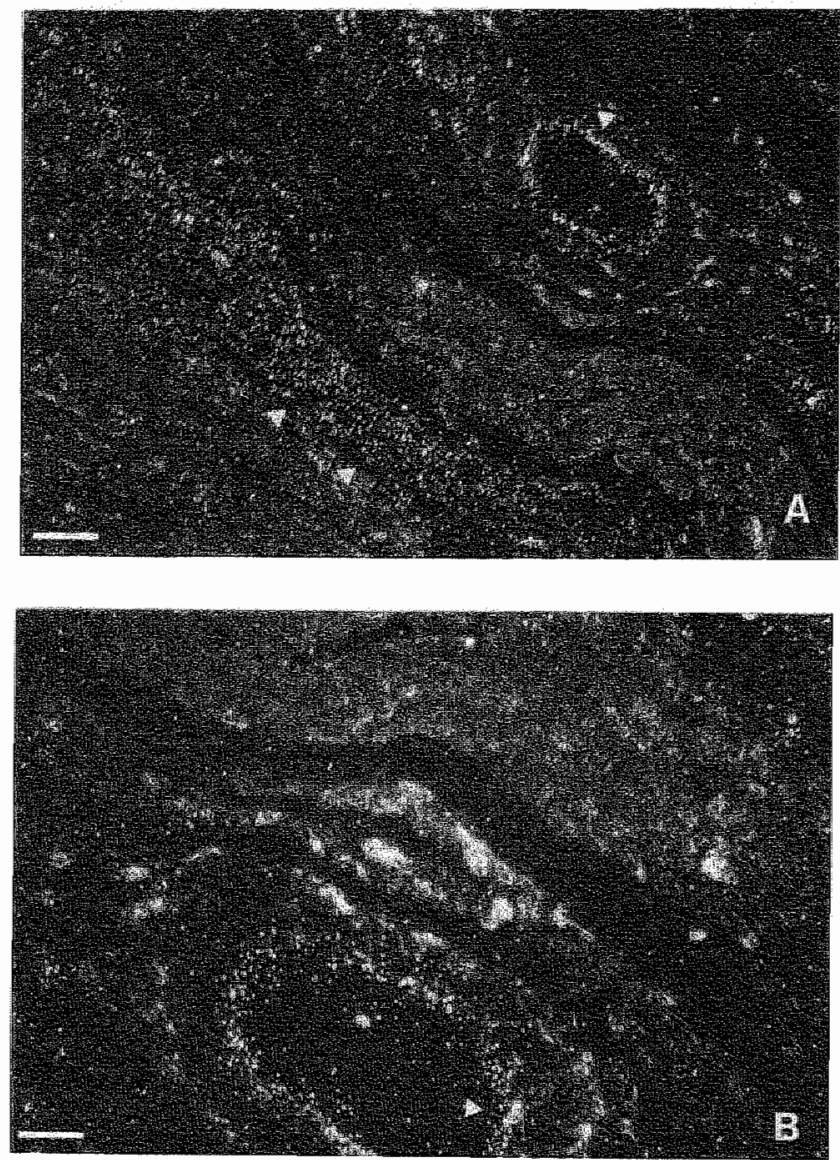

Flgure 3. Photomicrograph (darkfield) in situ hybridization on heart tissue sections, 4 days after $\mathrm{Ml}_{\text {, }}$

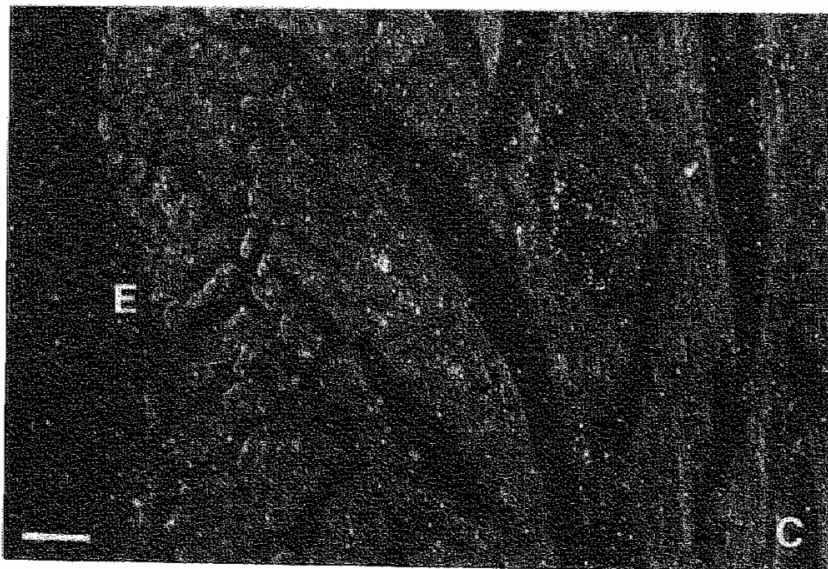
performed with a ${ }^{3}$ P-labeled antisense $\mathrm{ACE}$ riboprobe. A) Overview of ACE labeling in the border zone of the infarct area (lower arrowheads) and in endothelial cells of large vessels (upper arrowhead). Bar represents $72 \mu \mathrm{m}$. B) ACE labeling of endothelial cells (arrowhead) of a large vessel in the myocardium. Bar represents $18 \mu \mathrm{m}$ C) ACE labeling of the noninfarcted myocardium $(E=$ epicardium). Bar represents $72 \mu \mathrm{m}$. 

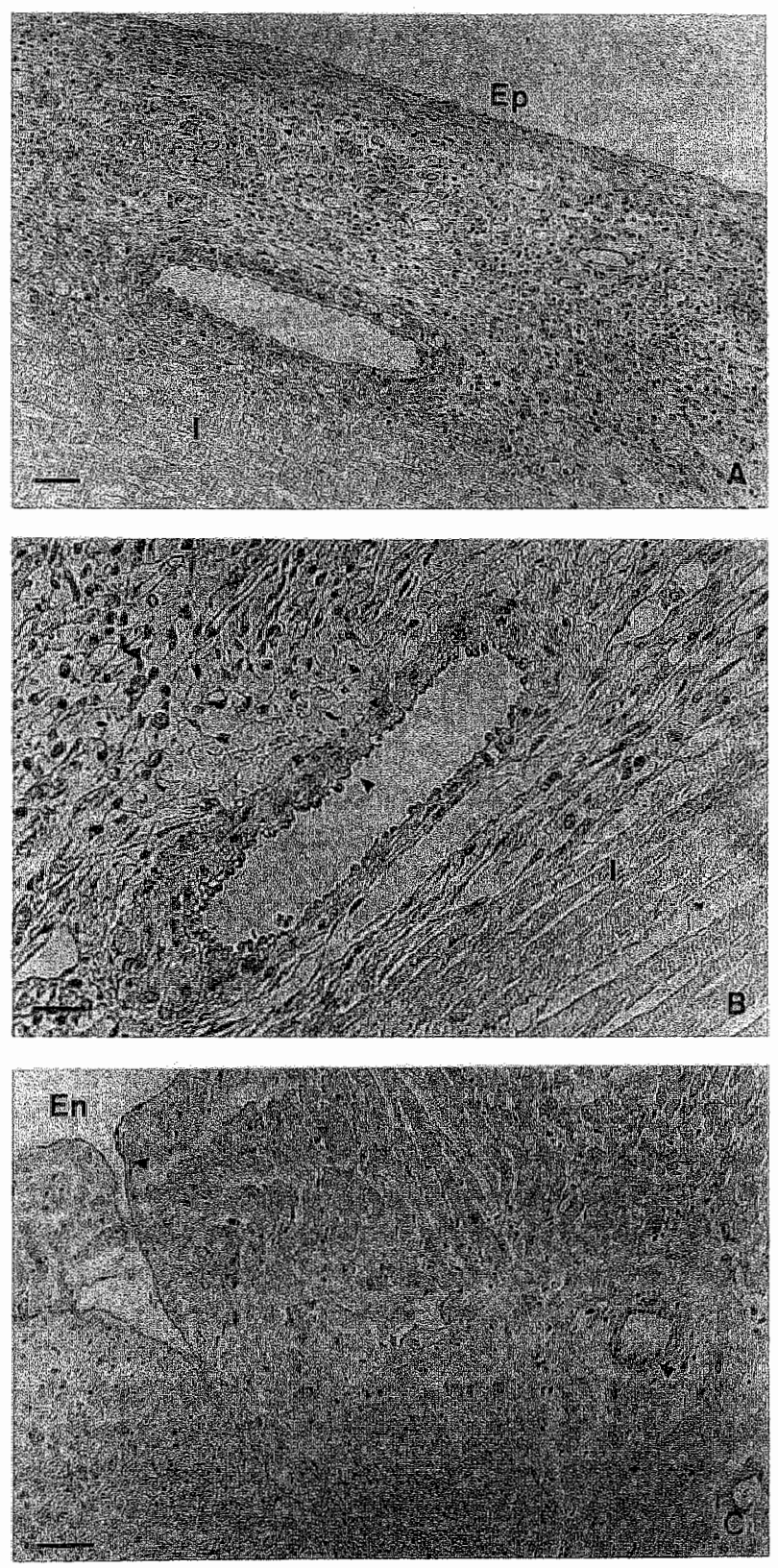

Flgure 4. Photomicrograph of immunohistochemistry of ACE on heart tissue sections, 4 days after Mi, performed with a polyclonal goat anti rat ACE (1:1000), counterstained with hematoxylin. A) Overview of ACE immunoreactivity in the border zone of the infarct area (lisinfarct area, Ep=epicardium). Har represents 72 $\mu \mathrm{m}$ B) ACE immunoreactivity in endothelial cells (arrowheads) of large and small vessels in the border zone of the infarct area myocardium (lminfarct area). Bar represents $18 \mu \mathrm{m}$ C) ACE immunoreactivity (arrowheads) in the endo. thelial cells of harger vessels and endocardium (En) in the non. infarcted myocardium. Bar represents $72 \mu \mathrm{m}$. 
Table 1: Tissue ACE activity in MI or sham animals

7 days

90 days

\begin{tabular}{ccccc} 
& SH & MI & SH & MI \\
\hline LV & $49.6 \pm 5.8$ & $131 \pm 20.3^{\circ}$ & $37.7 \pm 3.6$ & $134 \pm 25.9^{* \prime}$ \\
SE & $39.5 \pm 4.2$ & $51.7 \pm 5.7$ & $30 \pm 2.4$ & $85.1 \pm 24.1$ \\
RV & $52.3 \pm 6.1$ & $64.3 \pm 7.1$ & $42.1 \pm 4.7$ & $49.3 \pm 4.5$ \\
\hline
\end{tabular}

ACE activity in U/g/min in the infarcted left ventricle (LV), non-infarcted septum (SE) and right ventricle (RV) at 7 and 90 days after $M I 1$ or sham-operation. ${ }^{*} P<0.05$, * $P<0.01$, significantly different from sham.

infarcted myocardium, l.e. In the endocardial layer and in endothelial cells of the larger vessels.

\section{ACE activity}

The mean infarct size in the experimental Mll groups was $40.4 \pm 1.2 \%$ and $38.4 \pm$ $1.0 \%$ at 7 and 90 days after MI, respectively. This infarct size was representive for all MI animals in this study. Table 1 shows the ACE activity at 7 and 90 days after MI of sham-operation in the different compartments of the rat. ACE activity was significantly increased in the infarcted $L V$ at 7 days $(2.6$ fold) and 90 days ( 3.6 fold) after MI when compared to LV of the sham group. No significant differences in ACE activity were observed in the non-infarcted SE and RV at the two time points after MI, compared to the sham-group.

\subsection{DISCUSSION}

Although there is evidence that the intracardiac RAS may play a role in pathological processes like cardiac hypertrophy and wound healing, quantitative analysis of the components of the RAS combined with the localization of these components in the heart in pathological circumstances is lacking. In this study we quantified ACE mANA in the different compartments of the rat heart after MI. Ligation of the $\angle A D$ results in a mean infarct size of $40 \%$ and a $30 \%$ increase in mass of RV, SE and viable LV (1); thus the model seems appropriate for studying cardiac hypertrophy and wound healing. The quantification of ACE MRNA and ACE activity was combined with the localization of ACE mRNA and ACE protein.

ACE MRNA levels increased 3 -fold in the infarcted $L V$ at 4 and 7 days after MI. ACE activity also increased approximately 3 -fold in the infarcted LV at 7 and 90 days after MI. This increase in left ventricular ACE activity after MI is in accordance with the increase of ACE mANA amounts. Furthermore the increased ACE activity in the 
infarcted LV at 90 days after MI, suggests a low turnover of the ACE enzyme. We can not exclude a possiblle contribution of plasma ACE activity, although this is not likely since plasma ACE levels are not elevated in these stages of MI (32). In situ hybridization and immunohistochemistry localized ACE MRNA and protein in the border zone of the infarcted $L V$. In a qualitative study in rats, using a similar infarct model as in our study, Hirsch et al. (17) found a 2-fold increase of right ventricular ACE mRNA expression and enzyme-activity and a 2-fold increase of interventricular septal ACE-activity, 85 days after infarction, with normal plasma $A C E$ and renin levels. Pinto et al. (32) observed an increase of ACE activity in the apex at 3,5 and 80 days after $\mathrm{MI}$ and in the RV at 3 days after MI. The infarcted LV was, however. not included in their analysis. In another study (13) in the same model an increase of cardiac ACE, estimated by radioligand binding was observed in all the compartments of the rat heart, with the highest increase (4-fold) in the infarct region. Sun et al. (39) found an increase of ACE binding in the infarcted LV from 1 week after MI. In the free left ventricular wall of failing human hearts, Studer et al. (38) demonstrated a 3-fold increase of ACE mRNA by competitive RT-PCA, while there was no increase of gene expression of chymase, an alternative ANG II forming enzyme. These latter studies are in agreement with our study, indicating an activated intracardiac RAS after M!. The timing and site of activation of ACE demonstrated by Hirsch et al. (17) was different from our study. In our study, however, ACE mRNA amounts were measured by the quantitative competitive RTPCR from 1-90 days, while in the study from Hirsch et al. (17) ACE mRNA expression was estimated with a qualitative PCR at one time after MI.

Also other components of the intracardiac RAS are increased after $\mathrm{MI}$, including a transient increase in angiotensinogen (AO) mRNA (24) in the non-infarcted $L V$ of the rat, and an increase of angiotensin receptor density at sites of $\mathrm{MI}$ and pericardial fibrosis as early as three days after MI (39).

In chronic experimental aortic stenosis "cardiac hypertrophy was associlated with a 4-fold increase of ACE MPNA expression and a 30\% increase of ACE-activity in the hypertrophied LV. The intracardiac conversion rate from angiotensin I (ANG I) to ANG $\|$ was doubled in isolated hypertrophied hearts, whille treatment with the ACElinhibitor enalaprilat significantly decreased the conversion from ANG | to ANG I| (34). Experimental and clinical studies have demonstrated that ACE-1 treatment in heart failure results in a decrease of hypertrophy, LV dilatation and mortality $(29,30)$, even with a non-hypotensive dose of an ACE-1 (25). Furthermore ACE inhibition reduces interstitial DNA synthesis in the early phase after MI (19). In chapter 3 we described decreased levels of atrial AO mRNA, 7 days after aorta coarctation. In the same model of pressure overload in rats, increased AO mRNA expression (3), ANG 11 concentrations and increased AT1 a mRNA levels and angiotensin receptor density (41) were detected in the myocardium. These observations confirm the importance of the intracardiac RAS in pathological circumstances, like pressure overload cardiac hypertrophy and MI.

Although the above mentioned studies suggest that the RAS is involved in the 
development of hypertrophy, the lack of increase in ACE MRNA and activity in the non-infarcted hypertrophied SE and RV after $M$ : in the present study indicates that cardiac hypertrophy is not necessarily assoclated with activation of intracardiac ACE in the rat heart after MI. The activation of ACE both at the MRNA, protein and activity level in the inflarcted LV suggest, however, a role for the intracardiac RAS in the healing of the infarct.

A role for the RAS in wound healing has been suggested before. In the rat skin tissue ANG II levels increased as early as 6 hours with a peak (10-fold increase) at 24 hours after injury (31), which was associated with a downregulation of the AT1 receptor (18). Increased amounts of ACE protein were also found in the inflammation zone of scars of human (9) and rat $(14,39)$ infarcted hearts, 3 and 7 days after MI, the same time period of increase as in the present study. Increased ACE-immunoreactivity following $M I$ in the rat was predominantly localized in endothelial cells of capillaries in the border zone of the infarct, whereas in the noninfarcted myocardium ACE-staining was observed in arterioles and arteries (14). Although we localized the ACE mRNA and ACE protein predominantly in the endothelial cells, we can not exclude the presence of ACE mANA and protein in other cells like macrophages or (myo)fibroblasts. It is possible that (myo)fibroblasts produce Increased amounts of $A C E$, because they express the components of the RAS $(10,43)$. Furthermore myofibroblasts appear within 4 days after infarction (44). ANG II has been shown to induce the expression of collagen, TGFB and PDGF $(6,27,37)$, which have been implicated to play a role in wound healing and which are produced by these myofibroblasts $(12,16)$.

Another important protein in wound healing is collagen and ACE may be involved in collagen deposition in the infarct zone. Increased collagen I and III mRNA expression was demonstrated after MI (7). This increase runs in parallel with the increase in ACE mRNA expression, 4 and 7 days after MII in this study. Furthermore collagen deposition could be suppressed by the ACE inhibitors captopril (19) and perindopril (26) and by the AT1-antagonist losartan (36). In cultured adult rat cardiac fibroblasts. ANG II directly stimulated collagen synthesis and inhibited collagenase activity (5), resulting in accumulation of collagen. The presence of ACE in tissue, largely composed of collagen, such as in the heart valves, the adventitia of larger vessels and intramyocardial arteries supports this role (45). Sun et al. (40) found a high-affinity ACE binding in microscoplc scars and perivascular fibrosis in the myocardium and atria after chronic treatment (4 and 6 weeks) with ANG II or aldosterone.

The localization of ACE in the capillary endothellum in the border zone of the inferct area suggests a role in neovascularization. Kuizinga et al. demonstrated that $30 \%$ of the proliferating cells following $\mathrm{MI}$ are endothellial cells, suggesting vascular outgrowth after MI (20). ANG II has been shown to induce formation of new blood vessels in the rabbit cornea (15). Furthermore a dose-dependent induction of angiogenesis was found in the chick embryo chorioallantoic membrane after treatment with ANG $\|(21)$. This response was resistant to the AT1-antagonist 
angiogenesis was found in the chick embryo chorloallantolc membrane after treatment with ANG II (21). This response was resistant to the ATH-antagonist losartan and the AT2-antagonist PD123319, but could be blocked by the AT2antagonist CGP42112A (22).

In conclusion, our data suggest that the intracardlac ACE does not play a dominant role in the development of cardiac hypertrophy in the experimental MI model in the rat, since there was no activation of ACE in the hypertrophied SE and RV. On the other hand the activated ACE in the border zone of the infarct suggests the involvement of intracardiac ACE in the wound healing of the infarct area. The intracardiac RAS could thereby play an important role in the development of fibrosis and neovascularization after MI.

\section{REFERENCES}

1. Anversa $P$, Beghi $C$, MoDonald SL, Levicky $V$, Kikkawa $Y$, Olivetti $G$. Morphometry of right ventricular hypertrophy induced by myocardial infarction in the rat. Am J Pathol 1984; 116.504513.

2. Baker KM, Aceto JF. Angiotensin II stimulation of protein synthesis and cell growth in chick heart cells. A.m J Physiol 1990; 259:H610-H618.

3. Baker KM, Chernin MI, Wixson SK, Aceto JF. Renin-angiotensin system involvement in pressureoverload cardiac hypertrophy in rats. Am J Physiol 1990; 259:H324-H332.

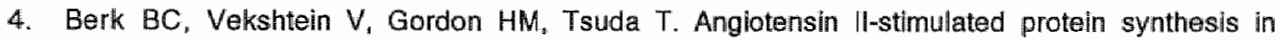
cultured vascular smooth muscle cells. Hypentension 1989; 13:305-314.

5. Brilla $C G$, Reams GP, Maisch $B$, Weber $K T$. Renin-angiotensin system and myocardial fibrosis in hypertension: regulation of the myocardial collagen matrix. Eur Heart $\& 1993 ; 14$ Suppl J:57-61.

6. Brilla $C G$, Zhou $G$, Matsubara $L$, Weber $K T$. Collagen metabolism in cultured adult rat cardiac fibroblasts: response to angiotensin II and aldosterone. J Mol Cel/ Cardiol 1994; 26:809-820.

7. Cleutjens JPM, Verluyten MJA, Smits JFM, Daemen MJAP. Collagen remodeling after myocardial infarction in the rat heart. Am I Pathol 1995; 147:325-338.

8. Daemen MJ, Lombardi DM, Bosman FT, Schwartz SM. Anglotensin II induces smooth muscle cell proliferation in the normal and injured rat arterial wall. Circ Res 1991; 68:450 456.

9. Danilov SM, Chumachenko PV, Andreeva YV, Printseva OY Lacis RV. Angiotensin converting enzyme expression in the inflammation zone of human myocardial infarction and rat model of skin injury.J Hypertens Suppl 1993; 11 (Suppl. 5);:S232-S233.

10. Dostal DE, Rothblum KN, Conrad KM, Cooper GR, Baker KM. Detection of angiotensin I and II in cultured rat cardiac myocytes and fibroblasts. Am J Physio 1992; 263:C851-C863.

11. Dzau VJ. Cardiac renin-angiotensin system. Molecular and functional aspects. Am J Med 1988; 84:22-27.

12. Eghbali $M$, Tomek $A$, Sukhatme VP, Woods $C$, Bhambi B. Differential effects of transforming growth factor-betal and phorbol myristrate acetate on cardlac tibroblasts: regulation of fibrillar collagen mRNAs and expression of early transcription factors. Circ Res 1991; 69:483-490.

13. Fabris $B$, Jackson $B$, Kohzuki $M$, Perich $R$, Johnston $C I$. Increased cardiac angiotensin-conwerting enzyme in rats with chronic heart failure. Clin Exp Pharmacol Physial 1990; 17:309-314.

14. Falkenhahn M, Franke $F$, Bohle $R M$, Zhu YC, Stauss HM, Bachmann $S$, Danilov $S$, Unger $T$. Cellular distribution of angiotensim-converting enzyme alter myocardial infarction. Hypertension $1995 ; 25: 219-226$ 
15. Fernandez LA. Twickler J, Mead A. Neovascularization produced by angiotensin II. J Lab Chn Mod 1985;105:141-145.

16. Gabbian $\mathrm{G}, \mathrm{Ay}$ an $\mathrm{GB}$, Maino G. Presence of modified fibroblasts in granulation tissue and their possible role in wound contraction. Experientia $1974: 27: 549-550$.

17. Hirsch AT, Talsness CE, Schunkert H, Paul M, Dzau VJ. Tissue-specific activation of cardiac anglotensin converting enzyme in experimental heart failure. Circ Res 1991; 69:475-482.

18. Kinura $B$, Sumners $C$, Phillips MI. Changes in skin anglotensin II receptors in rats during wound healing. Biochem Biophys Res Commun 1992; 187:1083-1090.

19. Wan Krimpen $C$, Smits JFM, Cleutjens JPM. DNA synthesis in the non-infarcted cardiac interstitium is imcreased after left coronary artery ligation in the rat: effects of captopril. $J$ Mol Cell Cardiol $1991 ; 23: 1245-1253$.

20. Kulzinga MC Cleutjens JPM, Smits JFM, Daemen MJAP. Griffonia simplificolia I (GSI): a suitable rat cardiac microvascular marker on paraffin embedded tissue. J Mol Cell Cardiol 1992; 24 (Suppl, V):S57.

21. Le-Noble FA, Hekking JW, Van-Straaten HW, Slaaf DW, Struyker-Boudier HA. Angiotensin II stimulates angiogenesis in the chorio-allantoic membrane of the chick embryo. Eur J Pharmacol $4991 ; 195 ; 305-306$.

22. Le-Noble FA, Schreurs NH, van-Straaten HW, Slaaf DW, Smits JF, Rogg H, Struijker-Boudier HA. Evidence for a nowel angiotensin II receptor Involved in angiogenesis in chick embryo chorioallantole membrane. Am J Physiol 1993; 264:R460-A465.

23. Lindpaintner $K$, Jin MW, Niedermaier $N$, Wilhelm MJ, Ganten D. Cardiac angiotensinogen and its local activation in the isolated perfused beating heart. Circ fies 1990; $67: 564-573$.

24. Lindpaintmer K, Lu W, Neidermaier N, Schieffer B, Just H, Ganten D, Drexler H. Selective activation of cardiac angiotensinogen gene expression in post-infarction ventricular remodeling in the rat. J Mol Cell Cardiol 1993; 25:133-143.

25. Linz W. Scholkens BA, Ganten D. Converting enzyme inhibition specifically prevents the development and induces regression of cardiac hypertrophy in rats. Clin Exp Hypertens A 1989; $11: 1325-1350$

26. Michel JB, Lattion AL, Salzmann JL, Cerol ML, Philippe M, Camilleri JP, Corvol P. Hormonal and cardiac effects of converting enzyme inhibition in rat myocardial infarction. Circ Res 1988; 62:641 650.

27. Naftilan Av, Pratt RE, Dzau VJ. Induction of platelet-derived growth factor A-chain and c-myc geme expressions by anglotensin II in cultured rat vascular smooth muscle cells. J Chin Invest $1989 ; 83: 1419-1424$.

28. Naftilan AJ, Pratt RE, Eldridge CS, Lin HL, Dzau VJ. Angiotensin Ill induces c-fos expression in smooth musche via tramscriptional contro: Hypertension $1989 ; 13: 706-711$.

29. Pfeffer MA, Braunwals E, Moye LA, Basta L, Brown EG, Cuddy TE, Davis BR, Geltman EM, Goldman $S$, Flaker GC, Klein M. Lamas GA, Packer M, Rouleau J, Rouleau Jl, Rutherford J, Wertheimer $\mathrm{WH}$. Hawkins MC, on behalf of the SAVE Investigators. Effect of captopril on mortality and morblity in patients with left ventricular dysfunction after myocardial infairction-results of the survival and wentricular enlargement tr.all. N Engl J Med 1992; 327:669-677.

30. Pfeffer MA, Pleffer JM, Steinberg C. Finn P. Survival after an experimental myocardial infarction: beneficial effects of long-term therapy with captopril Circulation 1985; 72:406-412.

31. Phillips MI. Kimura B, Krim AJ, Konioek JA, Fossum GT. Anglotensin II (ANG II) in skim may act as a growth factor and enhance wound healing. FASEB I 1991; 5:A904 (abstract):3103. 
32. Pinto $Y M$, de-Smet $B G$, van-Gilst $W H$, Scholtens $E$, Monnink $S$, de-Graeff $P A$, Vlesseling $H$. Selective and time related activation of the cardiac renin-angiotensin system after experimental heart failure: relation to ventricular function and morphology. Cardiovasc Res 1993; 27:19331938.

33. Sadoshima $\$$, Izumo S. Molecular characterization of angiotensin II--induoed hypertrophy of cardlac myocytes and hyperplasia of cardiac fibroblasts. Critical role of the AT1 receptor sublype. Circ Res $1993 ; 73: 413-423$.

34. Schunkert $H_{4}$ Dzau $V_{\|}$. Tang SS, Hirsch AT, Apstein CS, Lorell BH. Increased rat cardiac angiotensin converting enzyme activity and mRNA expression in pressure overload left ventricular hypertrophy. Effects on coronary resistance, contractility, and relaxation. $I$ Clin Invest $1990 ; 86: 1913-1920$.

35. Searle PF, Tata RJ. Vitellogenin gene expression in male xenopus hepatocytes during primary and secondary stimulation with estrogen in cell cultures. Cell 1981;23:741-747.

36. Smits JF, van-Krimpen C, Schoemaker RG, Cleutjens JP, Daemen M.J. Angiotensin II receptor blockade after myocardial infarction in rats: effects on hemodynamics, myocardial DNA synthesis, and interstitial collagen content. I Cardiavasc Pharmacol 1992; 20:772-778.

37. Stouffer GA, Owens GK. Angiotensin II-induced mitogenesis of spontaneously hypertensive ratderived cultured smooth muscle cells is dependent on autocrine production of transforming growth factor-beta. Circ Res 1992; 70:820-828.

38. Studer $R$, Reinecke $H$, Muller $B_{3}$ Holtz J, Just $H$, Drexler $H$. Increased anglotensin-l converting enzyme gene expression in the failing human heart. J Clin Invest 199:; $94: 301-310$.

39. Sum $Y$, Cleutjens JPM, Diaz-Arias AA, Weber KT. Cardiac angiotensin converting enzyme and myocardial fibrosis in the rat. Cardiovasc Res 1994; 28:1423-1432.

40. Sun $Y$, Ratajska $A$, Zhou $G$, Weber $K T$. Angiotensin-converting enzyme and myocardial fibrosis in the rat receiving angiotensin $\| l l$ or aldosterone. $J$ Lab Clin Med 1993; 122:395-403.

41. Suzuki J, Matsubara $H$, Urakami $M$, Inada $M$. Rat angiotensin II (type 1A) receptor mANA regulation and subtype expression in myocardial growth and hypertrophy. Circ Res 1993: 73:439. 447.

42. Taubman MB, Berk BC, Izumo $S$, Tsuda $T$, Alexander AW, Nadal-Ginard B. Angiotensin II induces c-fos mANA in aortic smooth muscle. Role of $\mathrm{Ca2}+$ mobilization and protein kinase $\mathrm{C}$ activation. J Biol Chem 1989; 264:526-530.

43. Villarreal FJ, KIm NN, Ungab GD. Printz MP, Dillmann WH. Identification of functional anglotensin II receptors on rat cardiac fibroblasts. Circulation 1993; 88:2849-2861.

44. Willems IEMG, Havenith MG, De Mey JGA, Daemen MJAP. The alpha-smooth muscle actinpositive cells in healing human myocardial scars. Am J Pathol 1994; 145:868-875.

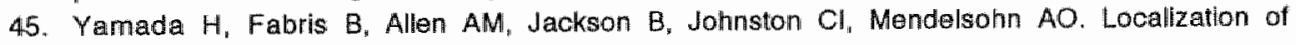
angiotensin converting enzyme in rat heart. Circ Fes 1991; 6i8:141-149. 



\section{CHAPTER 5}

ACTIVATION OF THE RENIN GENE IN THE INFARCT ZONE FOLLOWING MYOCARDIAL INFARCTION IN THE RAT 


\section{ABSTRACT}

Data on the activation of renin, the rate-limiting enzyme of the renin-angiotensinsystem (RAS) cascade, after myocardial infarction (MI), are lacking. In the present study we therefore quantified and localized renin mRNA in the infarcted rat heart. WKY rats underwent ligation of the left descending coronary artery, resulting in MI, or a sham-operation. At different time points after $M$, ranging from 1 to 90 days ( $n=6$ per group), hearts were removed and divided into infarcted left ventricle ( $L V$ ), noninfarcted septum (SE) and right ventricle (RV). The tissues were used for total RNA. isolation or formalin fixed for in situ hybridization. Renin mRNA content was quantified in the different compartments by the compelitive reverse transcriptase polymerase chain reaction (AT-PCA). Furthermore, atrial natriuretic factor (ANF) mANA expression, a marker for cardiac hypertrophy, was determined by Northern blot hybridization analysis in the different compartments of the heart, at 1, 7 and 90 days following surgery. We found a 3.8, 17 and 8.4-fold increase $(p<0.05)$ in renin mPNA in the infarcted LV at 2,4 and 7 days after MI, respectively. At 4 days after MI a slight increase of renin mRNA expression was observed in the SE. At other time points after MI or sham-surgery, renin mRNA levels were near the limit of detection. The results of the in situ hybridization studies were in accordance with these findings, showing increased renin mRNA expression around the infarct area, at 4 days after MI. Renin mANA was not localized in cardlomyocytes and, in contrast to our findings with angiotensin l-converting enzyme (ACE) (chapter 4), renin mRNA was not predominantly localized in endothelial cells. Renin mRNA expression in the non-infarcted myocardium was very low and not different from shams. ANF mRNA increased approximately 2 -fold in all compartments of the heart at 1,7 and 90 days after MI. The low amounts of renin mRNA in the non-infarcted hypertrophied myocardium, indicate that the intracardiac synthesis of renin does not play a dominant role in the development of cardiac hypertrophy in the rat heart after MI. In addition, the increased renin mRNA expression in the border zone of the infarcted LV early after infarction suggests a role for intracardiac synthesized renin in infarct healing.

\subsection{INTRODUCTION}

Although the intracardiac synthesis of most components of the RAS is well established now, the existence of an increased intracardiac synthesis of renin is still not clear. In the isolated perfused rat Langendorff heart, both angiotensin | and angiotensin 11 production were dependent on extracardiac renin (11). Moreover, in a nephrectomy study Danser ef al. (5) concluded that cardiac renin originates from the kidney. While several investigators could detect renim mRNA expression in normal hearts $(6,14)$, others did not find cardiac renin mRNA expression (9).

In addition to the ongoing discussion on the possible intracardiac synthesis of renin, little is known about the activation of the renin gene in cardiac hypertrophy. 
Boer et al. (4) recently described an up to 40-fold increase of cardiac renin mANA expression, 7 days after induction of volume-overload cardiac hypertrophy. Also in spontaneously hypertensive rats (SHR) increased cardiac renin and angiotenstinogen mRNA expression were demonstrated.

Simillarly, activation of other components of the RAS in cardiac hypertrophy has been demonstrated. In the previous chapter (chapter 4) activation of the ACE gene and protein were described after MI in the border zone of the infarct area. Others also demonstrated increased ACE and angiotensinogen mRNA in the myocardium following $M I(8,12)$. In addition, cardiac ACE and angiotensinogen mRNA and ACE activity were increased in pressure-overload induced cardiac hypertrophy $(3,17)$.

No data are available on the regulation and localization of renin mRNA after MI, a model which results in cardiac hypertrophy. In the present study no increase of renin mRNA was found in the non-infarcted hypertrophied segments, which exhibited elevated levels of ANF mRNA, a marker of cardiac hypertrophy. Renin mRNA amounts were, however, elevated in the border zone of the infarct area, suggesting a role for intracardiac synthesized renin in wound healling after MI.

\subsection{MATERIALS AND METHODS}

\section{Surgery}

Adult male WKY rats were used, weighing $250-300 \mathrm{~g}$ at the beginning of the experiments. Rats underwent induction of MI (chapter 2.2.1) or sham-operation. At $1,2,4,7,14,21$ or 90 days after surgery infarct and sham rats $(n=6$ per time point per group) were killed by ether. In a second series of experiments, animals ( $n=3$ per group) underwent the same surgery as described above. Since the highest renin MRNA amounts were found at 4 days after MI, this time point was chosen for in situ hybridization.

\section{Tissue processing}

The heart was removed and a slice of tissue parallel to the base was cut and formalin fixed overnight and paraffin embedded for determination of the infarct size (chapter 2.3.1). The rest of each heart was divided in infarcted or non-infarcted (sham) LV, SE and RV. The tissues were subsequently frozen in liquid nitrogen and stored at $-70^{\circ} \mathrm{C}$.

MI or sham-operated animals ( $n=3$ per group) of the second series of experiments were sacrificed by ether overdose. The hearts were removed and cut in 2 parts parallel to the base. Both parts were formalin fixed overnight and paraffin embedded for determination of infarct size and in situ hybridization (chapter 2.6). 


\section{RNA isolation}

Total RNA was extracted using the LiCl/urea method (18) as described in chapter 2.3.2.

\section{Competitive AT $=$ PCR for renin}

The competitive RT-PCA was used for quantification of renin mRNA. The selection of the renin primers, creation of the internal standard, the reverse transcription and the PCR is described in chapter 2.4. The PCR-cycle used for renin was $0.5 \mathrm{~min}$ at $94^{\circ} \mathrm{C}, 0.5 \mathrm{~min}$ at $65^{\circ} \mathrm{C}, 1 \mathrm{~min}$ at $72^{\circ} \mathrm{C}, 40$ cycles.

\section{In situ hybridization}

The rat renin PCR fragment of $372 \mathrm{bp}$, described in chapter 2.4 .1 , was ligated in the TA-vector. A ${ }^{35}$ S-UTP-labeled antisense riboprobe was created by transcription using T7 RNA polymerase (Promega). Four $\mu \mathrm{m}$ sections, formalin fixed, paraffin embedded hearts were used for the in situ hybridization as described in chapter 2.6.

\section{Northern hybridization analysis}

ANF MRNA expression was used as an indicator for cardiac hypertrophy in the different compartments of the hearts in infarct and sham rats, 1, 7 and 90 days after surgery. A total of $15 \mu \mathrm{g}$ total RNA was used for the Northern blotting hybridization (chapter2.4.3). Specific primers for rat ANF were chosen. The upper primer was $5^{\prime}$ ACCAGAGAGTGAGCCGAGAC 3', the lower primer 5" AGTGGGAGAGGTAAGGCCTC $3^{\prime}$. Amplification resulted in a PCA fragment of 697 bp in length. Dideoxy sequencing showed a $100 \%$ homology with the rat ANF cDNA sequence (data not shown). This ANF PCR-fragment was used as a probe. The other probe used was the CDNA insert to 285 rRNA. Labeling and hybridization of the probes are described in chapter 2.5 .

\section{Statistioal analysis}

All data are presented as mean \pm SEM. Statistical differences were calculated using ANOVA and Bonferroni's t-test. Statistical significance was accepted at the level of $p<0.05$ (chapter 2.9).

\subsection{RESULTS}

Infarct size and ANF mRNA expression

The mean infarct size in the experimental Ml group at different time points was $44 \pm$ 


\section{ANF mRNA Expression}

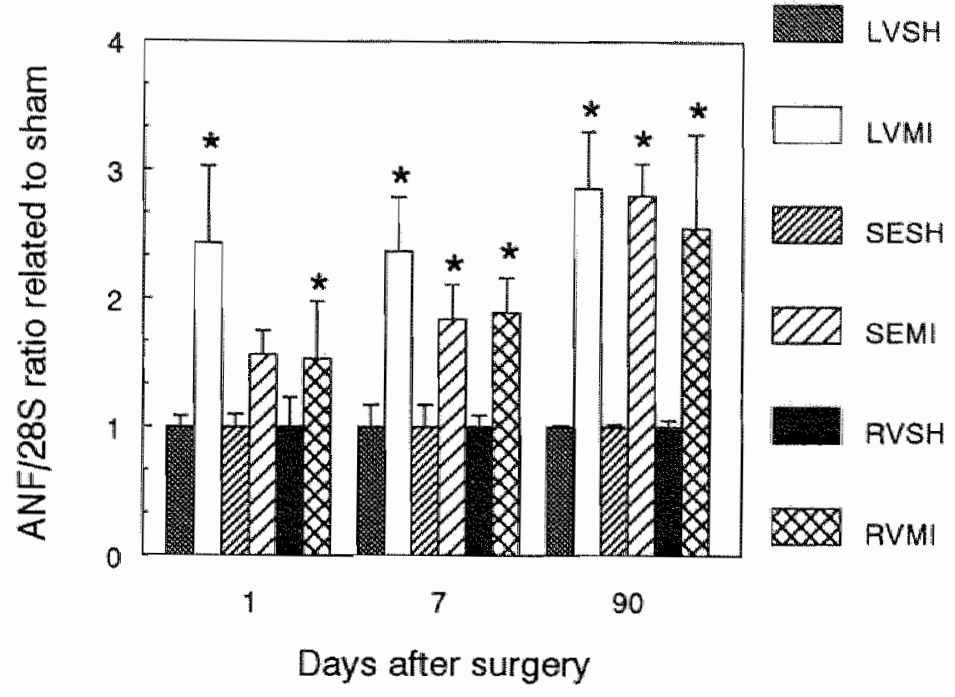

Figure 1. ANF mANA expression at 1,7 and 90 days after myocardial infarction (MD) or sham (SH)surgery in left ventricle (LVSH and LVMI), septum (SESH and SEMI), and right ventricle (AVSH and RVMI). The ANF/28S ratios of the MI animals were related to the sham ratios. " $P<0.05$, significantly different from sham.

$3 \%$. There were no differences in infarct sizes between the different groups. ANF mRNA expression was used as a marker for hypertrophy of the non-infarcted myocardium. ANF mRNA expression was significantly higher in the different compartments at all time points after MI. At 1 day after MI ANF mRNA was 2.4. 1.6 and 1.5 fold higher, at 7 days after $\mathrm{MI} 2.4,1.8$ and 1.9 fold higher and at 90 days after MI ANF MRNA was 2.9, 3 and 2.6 fold higher in LV, SE and RV, respectively. when compared to the ANF mRNA expression in the different compartments of the sham groups (figure 1). This suggests that cardiac hypertrophy occurred in the different compartments after MI.

\section{Competitive RT-PCR}

To first evaluate the levels of renin mRNA expression, a qualitative RT-PCR, i.e. RTPCR without an internal standard, was performed in duplicate on the RNA samples in the different compartments of the hearts at all time points after surgery. Renin mRNA expression was very low in all compartments of the sham-hearts at the different time points after surgery (1-90 days). In the MI group they were high in the 


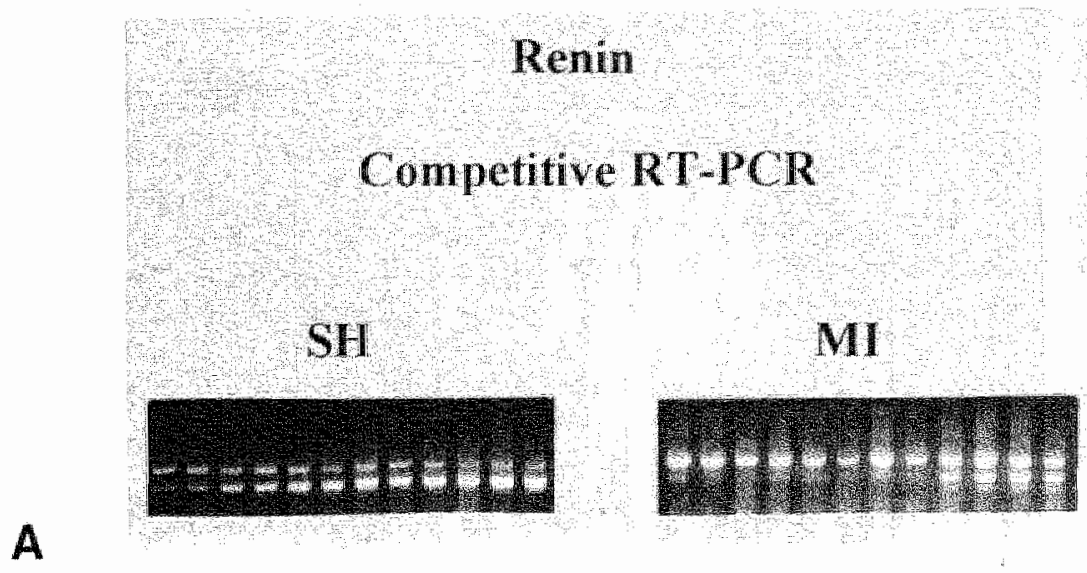

Left ventricle

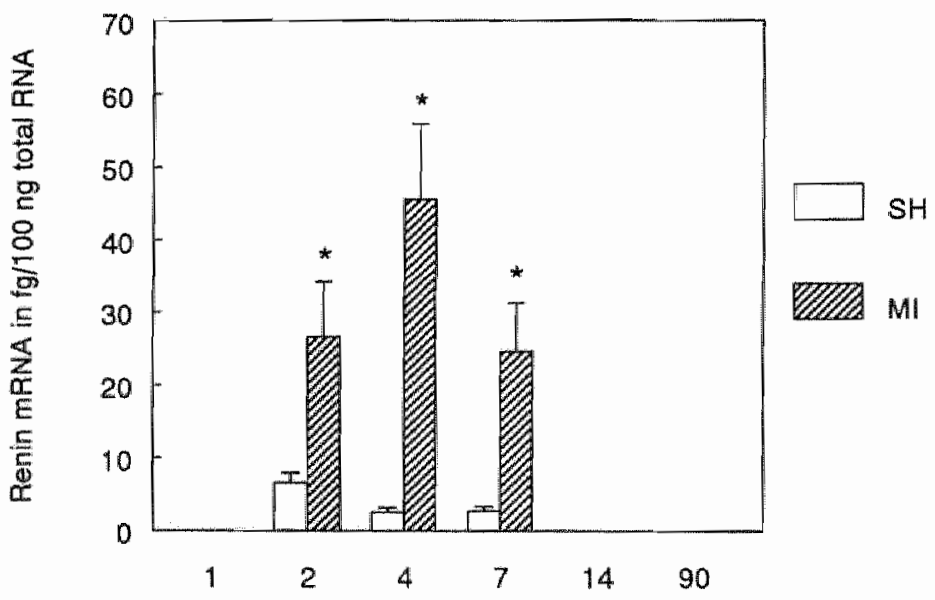

B

Days after surgery

Figure 2. A) Gel electrophoresis of the PCR products after competitive RT-PCR of renin in the infarcted (Mi) or sham (SH) left ventricle (LV), showing the target DNA (372 bp) and internal standard DNA (263 bp). A constant amount of $500 \mathrm{ng}$ total RNA was used together with increasing amounts amounts of internal standard RNA ( 10 to $400 \mathrm{fg}$ ). B) Renin mRNA amounts in MI or SH rats in LV, from 1 to 90 days after surgery. ${ }^{*} P<0.05$, significantly different from sham. 
infarcted left ventricles, at 2,4 and 7 days after MI and in the SE at 4 days after MI. Therefore quantification of renin MANA amounts by competitive AT-PCA Was restricted to these time points.

In the sham group renin mRNA levels were above the level of accurate quantification, in only 2 out of 6 left ventricles at 4 and 7 days after sham-surgery, whereas at 2 days after sham-surgery 4 samples were above the level of detection. Reducing the amounts of internal standard did not solve this problem. At 2 days after sham-surgery the mean renin mRNA levels in LV were $7.0 \pm 1.5 \mathrm{fg} / 100 \mathrm{ng}$ total RNA. At 4 and 7 days after sham-operation mean renin mRNA leveis in LV were 2.6 and $2.7 \mathrm{fg} / 100 \mathrm{ng}$ total RNA, respectively. Renin mRNA levels after MI were increased in the infarcted $L V$. At 2 days after $M I$ renin mRNA levels were $26.6 \pm 7.6$ $\mathrm{fg} / 100 \mathrm{ng}$ total RNA in the infarcted LV, which indicates a more than 4-fold increase in renin $m R N A$ levels in the infarcted $L V$ when compared to the sham group (figure $2 A$ and $B$ ). The renin mRNA levels in the 4 day infarcted $L V$ were $35.6 \pm 7.6 \mathrm{fg} / 100$ ng total RNA, indicating a more than 17-fold increase as compared to sham. At 7 days after $M I$ renin $m R N A$ levels in the infarcted $L V$ were $21.8 \pm 5.3 \mathrm{fg} / 100 \mathrm{ng}$ total RNA, a more than 8-fold increase when compared to sham animals.

In the SE of the sham animals renin mRNA levels were below the level of accurate quantification, whereas in the SE of the infarcted group at day 4 in 4 out of 6 animals renin mRNA levels could be quantified. Mean renin mRNA levels were $13.6 \pm 4.4 \mathrm{fg} / 100 \mathrm{ng}$ total RNA. At other time points after Ml in the SE and RV no increases of renin mRNA were found.

\section{In situ hybridization}

Since the highest renin MRNA levels were found at 4 days after $M I$, this time point was used for the localization of the renin mRNA in the infarcted heart and compared to sham hearts. The results of the in situ hybridization with the ${ }^{35} \mathrm{~S}$ labeled renin probe were in accordance with the data obtained by the competitive RT-PCR. High renin mRNA expression was found around the infarct area in the $L V$ at 4 days after MI (figure 3). Renin mRNA was most probably localized in (myo)fibroblasts and/or endothelial cells around the infarct area. Furthermore, we found that renin mRNA was not localized in cardiomyocytes of the infarcted and non-infarcted myocardium. In the non-infarcted myocardium renin mANA expression was very low and not distinguishable from the background labeling. Also in the sham-operated hearts at day 4 renin mRNA expression was very low and not distinguishable from the background labelling.

\subsection{DISCUSSION}

In the present study we observed increased renin IRANA amounts in the infarcted $L V_{*} 2,4$ and 7 days after MI. Renin mRNA levels were especially increased around the necratic area in the infarcted LV. Cardiomyocytes were negative for renin mRNA 

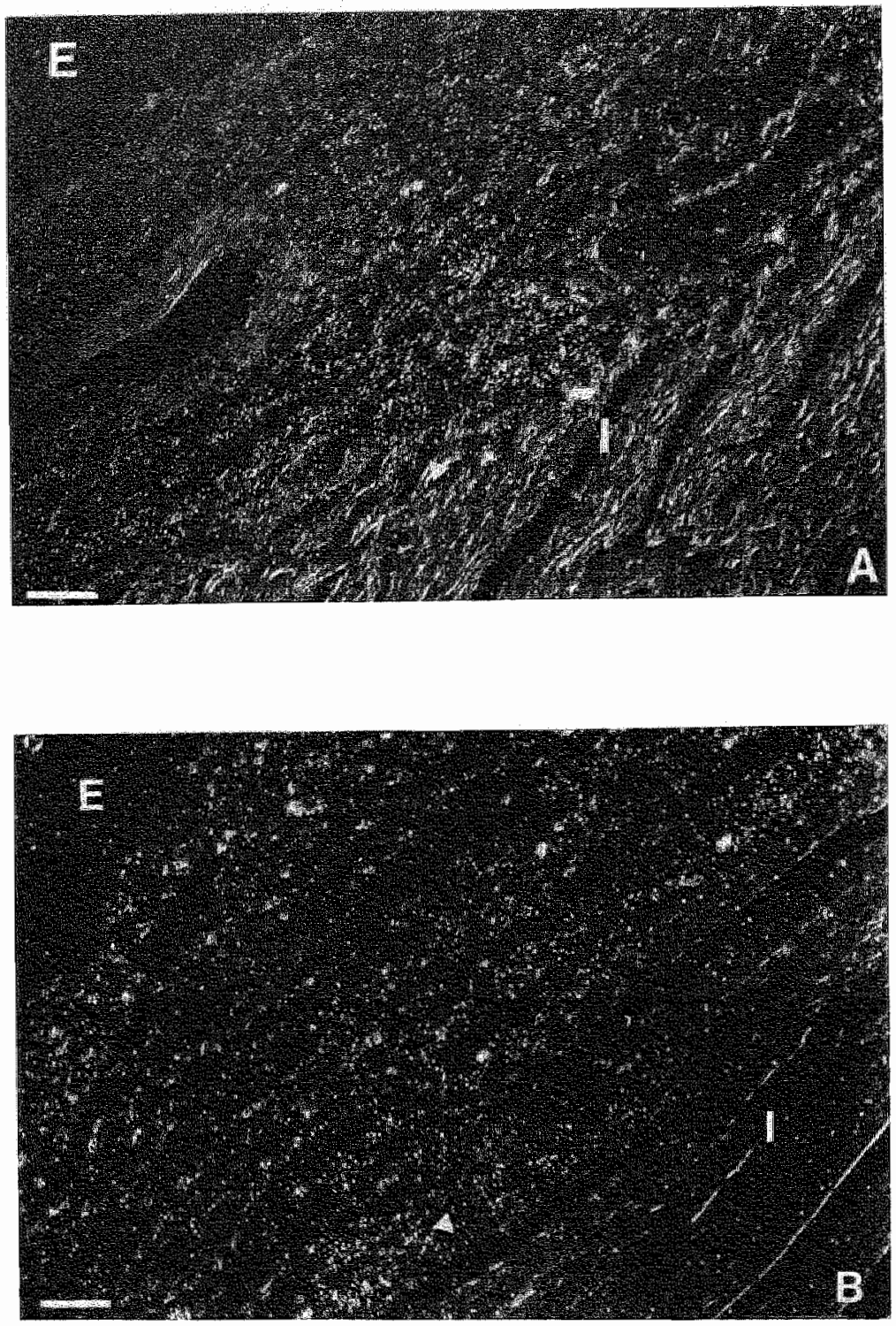

Flgure 3. Photomicrograph (dark-field) of in situ hybridization on heart tissue sections, 4 days after $M l_{\text {, }}$ performed with a ${ }^{36}$ S.labeled antisense renin riboprobe. A) Overview of renin labeling in the border zone of the infarct area (arrowhead). I infarct area; bar represents $72 \mu \mathrm{m}$. B) Fenin labeling in the border zone of infarct area (arrowhead). E = epicardium; bar represents $18 \mu \mathrm{m}$. 
expression. In contrast to a slight increase of renin mRNA in the SE at 4 days after MI, low to undetectable levels of renin mRNA amounts were found in the noninfarcted hypertrophied myocardium of infarct animals and in the ventricles of all sham hearts.

Experimental $\mathrm{MI}$ is a model that includes cardiac hypertrophy as well as infarct healing. The mean infarct size of the infarction group was $44 \%$. Although we did not measure hypertrophy in our animals as heart weights, Ml of this size have been reported to result in a 20-40\% mass increase of the non-infarcted myocardium $(1,2)$, The hypertrophic response of the myocardium after MI was corroborated in our studies by a significant increase of ANF mRNA expression in all compartments of the heart at 1,7 and 90 days after MI, when compared to sham hearts. ANF is induced in the early phase of cardiac hypertrophy and is used as a marker for cardiac hypertrophy (16).

The presence of renin mRNA has been detected in all compartments of the heart $(6,7)$, with highest mRNA levels in the atria. Elevated ventricular renin mRNA levels were found in neonatal rat hearts, but not in adults (6). However expression was very low, demonstrating the need for sensitive techniques, like RT-PCR. Cellular localization of renin mRNA was described by Dostal et al. (6). They found renin mRNA expression and protein synthesis in isolated neonatal rat heart myocytes and fibroblasts. However the localization of renin in pathophysiological circumstances is not known.

In other models of cardiac hypertrophy, activation of the components of the intracardiac RAS has been observed. Recently, Boer et al. (4) demonstrated an increase of renin mRNA in a volume-overload induced cardiac hypertrophy model in rats (4). At 1 day after surgery no increase of renin mRNA was observed. However, 7 days after aortacaval shunting a more than 40-folld increase of renin mRNA levels were observed by competitive RT-PCR. Angiotensinogen mRNA was not increased in that model. In spontaneously hypertensive rats (SHR), which develop marked cardiac hypertrophy, increased cardiac mRNA expression of both renin and angiotensinogen genes were demonstrated. In addition, increases of angiotensinogen and ACE mRNA levels, ACE activity, AT1 a mRNA and angiotensin receptor density have been observed in pressure-overtoad induced hypertrophy $(3,13,17,19)$.

To the best of our knowledge this is the first study demonstrating activation of the intracardiac renin gene following Ml. Our data suggest that the intracardiac synthesis is not necessary for the development of cardiac hypertrophy after MI in the rat, since renin was not activated in the hypertrophied non-infarcted myocardium. Activation of renin around the necrotic area in the early phase after MI, suggests, however, a role for intracardiac renin in the infarct healing process, which includes proliferation of endothelial cells and (myo)fibroblasts $(10,20)$.

In addition to the increased renin mRNA expression in the infarcted LV, we described in the previous chapter (chapter 4) the localized activation of the ACE gene and protein in the border zone of the infarct area in the early phase after MI, 
whereas in the SE and RV no changes in ACE gene and protein activity were observed. In chapter 4 we suggested a role for the intracardiac ACE in wound healing after MI by possibly affecting processes like cardiac fibrosis and angiogenesis, but a less important role in the development of cardiac hypertrophy after MI. The activation of the renin gene in the border zone of the infarct area in the early phase after MI is in agreement with the ACE data. In contrast to ACE, renin mRNA could not be lacalized in the endothelial cells of smaller and larger coronary vessels. However, in a paracrine/autocrine way the intracardiac renin may play a role in anglogenesis and fibrosis after $\mathrm{Ml}$ in the rat.

In summary, this study demonstrates activation of the renin gene around the necrotic area in the early phase after MI, while no increase in renin mRNA levels was observed in the hypertrophied non-infarcted myacardium. From these data we conclude that intracardiac synthesis of renin does not play a dominant role in the development of cardiac hypertrophy following $\mathrm{MI}$ in the rat. The presence of renin MANA around the necrotic area suggests a role for intracardiac renin synthesis in wound healing. The increased ACE mRNA expression (chapter 4) in the infarcted LV (15) in the same period in which renin activation occurs after MI, indicates activation of the intracardiac RAS in the infarcted LV in the early phase after MI.

\section{REFERENCES}

1. Anversa $P$, Beghi $C$, McDonald $S L$, Levicky $V$, Kikkawa $Y$, Olivetti G. Morphometry of right ventricular hypertrophy induced by myocardial infarction in the rat. Am J Pathol 1984; 116:504-513.

2. Anversa $P$, Loud AV, Levicky V, Guideri $G$. Left ventricular failure induced by myocardial infarction. 1. Myocyte hypertrophy. Am J Physial 1985; 248:H876-H882.

3. Baker KM, Chernin MI, Wixson SK, Aceto JF. Renin-angiotensin system involvement in pressureoverload cardiac hypertrophy in rats. Am il Physiol 1990; 259:H324-H332.

4. Boer $P H$, Ruzicka $M$, Lear $W$, Harmsen $E$, Posenthal J, Leenen FHH. Stretch-mediated activation of cardlac renin gene. Am of Physiol 1994, 267:H1630-H1636.

5. Danser AHJ, Kats JP. Admiraal PJJ, Derkx FHM, Lamers JMJ, Verdouw PD, Saxena PR, Schalekamp MADH. Cardiac renin and angiotensins. Uptake from plasma versus in situ synthesis. Hypertension 1994: 24:37-48.

6. Dostal DE, Fothblum $K \mathrm{~N}$, Chernin MI, Cooper GR, Baker KM. Intracardiac detection of angiotensinogen and renin: a lacalized renin-angiotensin system in neonatal rat heart. $A m J$ Physiol 1992; 263:C838-C850.

7. Dzau $V d_{8}$ Re RN. Evidence for the existence of renin in the heart. Clrculation 1987; 75:1134-1136.

8. Hirsch AT, Talsness CE, Schunkert $H$, Paul M, Dzau WJ. Tissue-specific activation of cardiac anglotensin converting enzyme in experimental heart failure. Circ Res 1991; 69:475-482.

9. Iwai N. Inagami $T$. Quantitative analysis of renin gene expression in extrarenal tissues by polymerase chain reaction method. J Hypertens 1992; 10:717-724.

10. Kuizinga MC, Cleutjens JPM, Smits JFM, Daemen MJAP. Griffonia simplificolia II (GSI): a suitable rat cardiac microvascular marker on paraffin embedded tissue. $J$ Mol Cell Cardiol 1992; 24 (Suppl. V: $: 557$ 
11. Lindpaintner $\mathrm{K}$, Jin MW, Niedermaier N, Wilhelm MJ, Ganten D. Cardiac angiotensinogen and its local activation in the isolated perfused beating heart. Circ Res 1990; 67:564-573.

12. Lindpaintmer $K$, Lu W, Neidermaier N, Schieffer B, Just H, Ganten D, Drexler H. Selective activation of cardiac angiotensinogen gene expression in post-infarction ventricular remodeling in the rat. Mol Cell Cardiol 1993;25:133-143.

13. Linz W, Scholkens BA, Ganten D. Converting enzyme inhibition specifically prevents the development and indiuces regression of cardiac hypertrophy in rats. Clin Exp Hypertens $A$ 1989; 11:1325-1350.

14. Okura $T$, Kitami $Y$, lwata $T$, Hiwada $K$. Quantitative measurement of extra-renal renin mANA by polymerase chain reaction. Biochem Biophys Res Commun 1991; 179:25-31.

15. Passier RCJJ, Smits JFM, Verluyten MJA, Studer $A_{1}$ Drexter $H_{n}$ Daemen MJAP. Activation of angiotensin-converting-enzyme expression in the infarct zone following myocardial infarction. Am J Physiol 1995; 269:H1268-H1276.

16. Sadoshima J. Izumo S. Molecular characterization of angiotensin II-winduced hypertrophy of cardiac myocytes and hyperplasia of cardiac fibroblasts. Critical role of the AT1 receptor subtype. Circ Res $1993 ; 73: 413-423$.

17. Schunkert H, Dzau VJ, Tang SS, Hirsch AT, Apstein CS, Lorell BH. Increased rat cardiac amgiotensin converting enzyme activity and mANA expression in pressure overload left ventricular hypertrophy. Effects on coronary resistance, contractility, and relaxation. af Clin Invest 1990; 86:1913-1920.

1B. Searle PF, Tata RJ. Vitellogenin gene expression in male xenopus hepatocytes during primary and secondary stimulation with estrogen in cell cultures. Cell 1981:23:741-747.

19. Suzuki J, Matsubara $H$, Urakami $M$, Inada $M$. Rat angiotensin II (type 1A) receptor mRNA regulation and subtype expression in myocardial growth and hypentrophy. Circ Res 1993; 73:439447.

20. Willems IEMG. Havenith MG. De Mey JGR, Daemen MJAP. The alpha-smooth muscle actinpositive cells in healing human myocardial scars. Am J Pathol 1994; 145:868-875. 



\section{CHAPTER 6}

ANGIOTENSINOGEN MESSENGER RNA EXPRESSION IN THE RAT

HEART AFTER EXPERIMENTAL MYOCARDIAL INFARCTION 


\section{ABSTRACT}

The activation of angiotensin 1-converting enzyme (ACE) and renin after myocardial infarction (MI), has been described in chapter 4 and 5 . In the present study we quantified and localized anglotensinogen (AO) mRNA in the infarcted rat heart. At different time points after MI, ranging from 1 to 90 days ( $n=6$ per group), hearts were removed and divided in infarcted left ventricle (LV), non-infarcted septum (SE) and right ventricle (RM). The tissues were used for total RNA isolation or formalin fixed and paraffin embedded for in situ hybridization. AO mRNA contents were quantified in the different compartments by the competitive reverse transcriptase polymerase chain reaction (RT-PCR). Furthermore, ANF mRNA expression, was determined by Northern blot hybridization analysis in the different compartments of the heart, at 1 , 7 and 90 days following MI (as described in chapter 5). Cardiac AO MRNA levels were extremely low. Mean cardiac AO mRNA levels were 435 ag/100 ng total RNA. No differences were observed between AO MRNA levels in sham and infarcted hearts in the different compartments at any time after surgery. ANF mRNA increased approximately 2-fold in all compartments of the heart at 1, 7 and 90 days after MI. In situ hybridization revealed an overall low density of AO mANA in the myocardium, with somewhat higher mRNA expression in the epicardium. These data demonstrate that intracardiac $A O$ is not activated after experimental MI, suggesting that intracardiac synthesis of $A O$ does not play a dominant role in the development of cardiac hypertrophy or infarct healing in the rat heart after MII.

\subsection{INTRODUCTION}

Little is known about the activation of the $A O$ gene in cardiac hypertrophy. Lindpaintner ef al. (5) reported a transient activation of AO MRNA in the noninfarcted LV of the rat, with peak levels at 5 days after MI. AO mRNA levels had returned to sham levels 25 days after $\mathrm{MI}$ (5). In spontaneously hypertensive rats (SHR) increased cardiac AO mANA expression was demonstrated (3). In contrast to the activation of the $\mathrm{AO}$ gene in $\mathrm{MI}$ - and hypertension-induced hypertrophy, Boer et al. (2) recently described that AO mRNA levels were not changed at 1 and 7 days after induction of vollume-overload induced cardlac hypertrophy.

No quantitative data and localization of AO mRNA after MI are available. In the present study AO mRNA levels were measured at different time points after surgery by competitive RT-PCA. At all time points measured, no differences of cardiac AO mRNA amounts were observed between infarcted and sham animals. Using in situ hybridization, AO mRNA was found to be localized in the epicardium of sham and infarcted rats, whereas AO mRNA was not detected in the rest of the hypertrophied myocardium of infarcted and sham rats. These data suggest that activation of the intracardiac AO gene does not play a dominant role in the development of cardiac thypertrophy and wound healing after MI in rats. 


\subsection{MATERIALS AND METHODS}

\section{Surgery}

Adult male WKY rats were used, weighing $250-300 \mathrm{~g}$ at the beginning of the experiments. Rats underwent induction of MI (chapter 2.2.1) or sham-operation. At $1,4,7,21$, or 90 days after surgery infarct and sham rats (n=6 per time point per group) were killed by ether overdose. In a second series of experiments, animals $(n=3)$ underwent the same surgery as described above. Since highest AO mRNA levels were found at 4 days after surgery, this time point was also chosen for in situ hybridization of $\mathrm{AO}$.

\section{Tissue processing}

The heart was removed and a slice of tissue parallel to the base was cut and formalin fixed overnight and paraffin embedded for determination of the infarct size (chapter 2.3.1). The rest of each heart was divided in infarcted or non-infarcted (sham) LV, SE and RV. The tissues were subsequently frozen in liquid nitrogen and stored at $-70^{\circ} \mathrm{C}$. In the second series of experiments, Ml or sham-operated animals ( $n=3$ per group) in these series were sacrificed with ether. The hearts were removed and cut in 2 parts parallel to the base. Both parts were formalin fixed overnight for determination of infarct size and in situ hybridization.

RNA isolation

Total RNA was extracted using the LiCl/urea method (9) as described in chapter 2.3.2.

\section{Competitive RT-PCR for angiotensinogen}

The competitive RT-PCR was used for quantification of AO mRNA. The selection of the $\mathrm{AO}$ primers, creation of the internal standard, the reverse transcription and the PCR is described in chapter 2.4. The competitive RT-PCA for AO consisted of a double PCR. The PCR was performed at $0.5 \mathrm{~min}$. at $94^{\circ} \mathrm{C}, 0.5 \mathrm{~min}$. at $62^{\circ} \mathrm{C}, 1 \mathrm{mir}$. at $72^{\circ} \mathrm{C}, 20$ cycles.

\section{In situ hybridization}

The rat AO PCR fragment of 482 bp, described in chapter 2.4.1, was ligated in the TA-vector. A ${ }^{35} \mathrm{~S}$-UTP-labeled antisense riboprobe was created by transcription using T7 RNA polymerase (Promega). Four $\mu \mathrm{m}$ sections, formalin fixed, paraffin embedded hearts were used for the in situ hybridization as described in chapter 2.6 . 
ANF MRNA expression was used as an indicator for cardiac hypertrophy in the different compartments of the hearts in infarct and sham rats, 1, 7 and 90 days after surgery. This is described in chapter 5.

\section{Statistical analysis}

All data are presented as mean \pm SEM. Statistical differences were calculated using the ANOVA and Bonferroni"s t-test. Significance was accepted at the level of $p<0.05$ (chapter 2.9).

\subsection{RESULTS}

\section{Infarct size and ANF mRNA expression}

The animals in this chapter were the same as in chapter 5 . Therefore, data concerning the ANF mRNA expression in the different compartments of the heart following $M I$ are described in chapter 5.3. In summary, ANF MRNA levels were increased in all compartments of the heart at the different time points after MI. The mean infarct size in the experimental $M$ ! group at different time points was $44 \pm 3 \%$.

\section{Competitive RT-PCR}

Cardiac AO levels were extremely low. For this reason we used a double set of primers, with the second set as nested primers. After this second PCR, AO levels could be quantified. There were no differences in AO mRNA levels between the compartments of the infarcted animals and the sham animals at the different time points after operation. Mean AO mRNA levels in LV were $870 \pm 250$ ag/100 ng total ANA (figure 1), in SE $421 \pm 167 \mathrm{ag} / 100 \mathrm{ng}$ total RNA and in RV $750 \pm 246 \mathrm{ag} / 100 \mathrm{ng}$ total RNA. AO mANA levels were elevated in the LV at 4 days after operation in sham animals when compared to the other time points after surgery in sham animals, indicating an activation of the $\mathrm{AO}$ gene by the operation itself.

\section{In situ hybridization}

Since the highest $A O$ mRNA levels were found at 4 days after surgery, this time point was also used for the localization of the AO mRNA in the infarcted heart and compared to sham hearts. The $A O$ mRN/A density in the sham and infarcted myocardium was very low. Only in the epicardium of sham and infarcted animals specific $\mathrm{AO}$ labeling was detected (figure 2). 


\section{Angiotensinogen}

\section{Competitive RT-PCR}
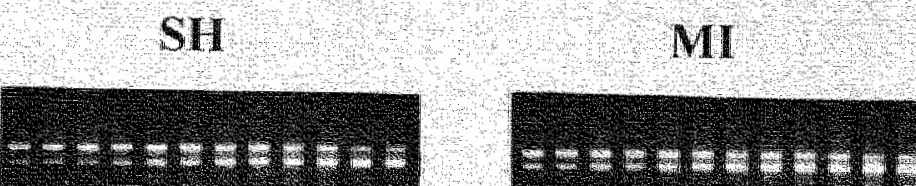

A

\section{Left ventricle}

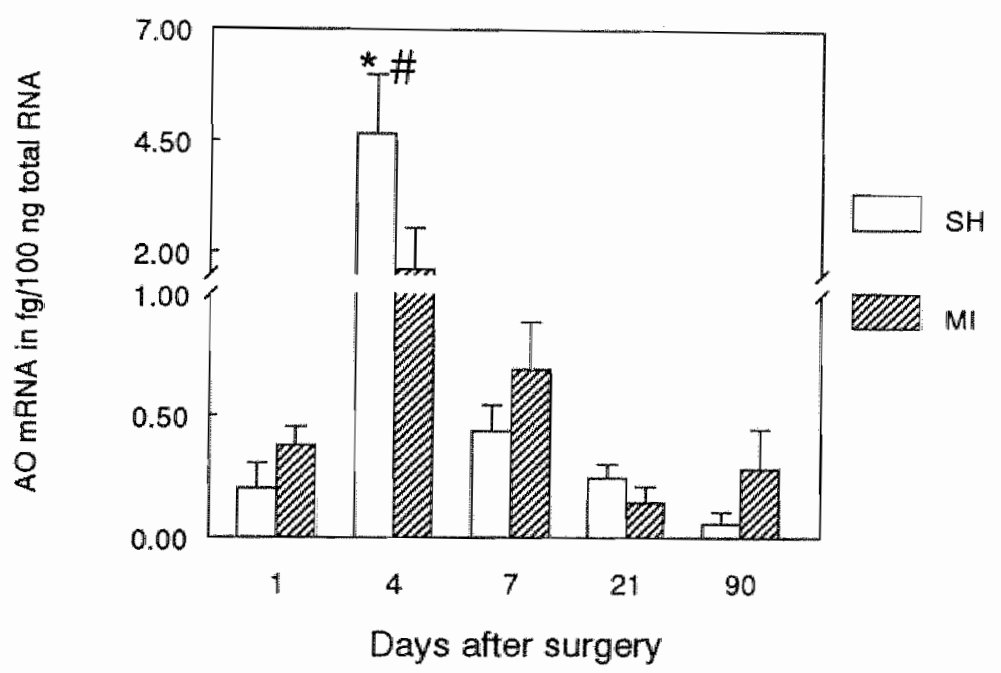

Figure 1. A) Gel electrophoresis after competitue RT-PCH of angiotensinogen in the infarcted (Ml) or sham (SH) left ventricle ( $\mathrm{LV}$ ), showing the target DNA (482 bp) and internal standiard DNA (372 bp). A constant amount of $500 \mathrm{ng}$ total RNA was used together with increasing amounts of internal standard RNA (1 to $50 \mathrm{fg}$ ). B) Angiotensinogen (AO) mRNA arnount in Mlor $S H$ rats in $L V$ at $1,4,7,21$ and 90 days after MI. " $P<0.05$, significantly different from sham at day 7.21 and $90 ;, P<0.01$, significantly different from sham at day 1. 


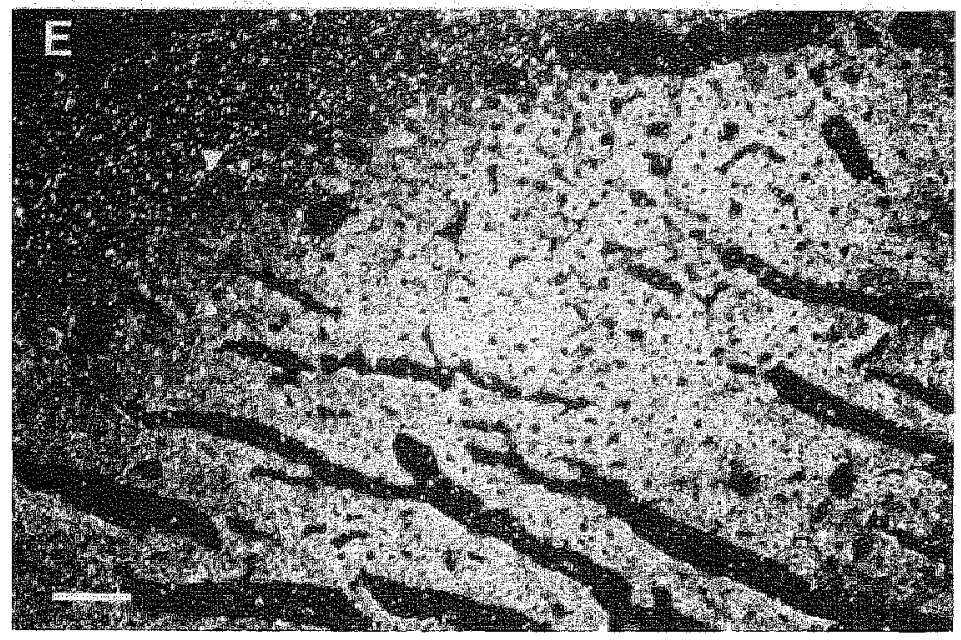

Flgure 2. Photomilcrograph (dark-field) of in situ hybridization on heart tissue sections, 4 days after MI, performed with a ${ }^{36}$ S-labeled antisense angiotensinogen riboprobe. Arrowhead indicates site of angiotensinogen labelling. $E$ epicardium; bar represents $72 \mu \mathrm{m}$.

\subsection{DISCUSSION}

In the present study we found very low levels of AO mRNA in the myocardium in sham and infarcted rats. We did not observe changes in AO mRNA expression in the different compartments of the heart at the different time points after MII. Apparently increased levels of AO mRNA were observed in the infarcted left ventricles at 4 days after surgery. However, these levels were not different between the infarcted and sham rats. In situ hybridization showed that this AO mRNA was predominantly localized in the epicardium.

Experimental $\mathrm{MI}$ is a model that includes cardiac hypertrophy as well as infarct healing. The mean infarct size of the infarction group was $44 \%$. The hypertrophic response of the myocardium after MI was corroborated in our studies by a significant increase of ANF mRNA expression in all compartments of the heart at 1 , 7 and 90 days after MI, when compared to sham hearts, as described in chapter 5 . ANF is induced in the early phase of cardiac hypertrophy and may be used as a marker for cardiac hypertrophy (7).

Lindpaintner et al. (5) used a RNase protection assay, and demonstrated a marginal activation (1.6-fold) of the AO gene in the non-infarcted LV at 5 days after MI. At 25 days after MI expression was no longer different from that in sham animals. Also in other models of cardiac hypentrophy, like SHR and aorta coarctation 
in rats, activation of the $\mathrm{AO}$ gene has been demonstrated $(1,11)$. However, in a volume-overload model no changes were observed in cardiac AO MRNA levels all 1 and 7 days after surgery (2). Our data suggest that the intracardiac synthesis of the RAS is not necessary for the development of cardiac hypertrophy following $M I$ in the rat, since $\mathrm{AO}$ was not activated in the hypertrophied non-infarcted myocardium. Infarction-induced hypertrophy is a combination of pressure and volume overload hypertrophy. The difference of activation of the cardiac AO gene may be explained by the difference of the experimental models used.

In addition, ACE and renin mRNA were increased in the border zone of the infarct area following $\mathrm{Mi}$, but not in the hypertrophied compartments of the noninfarcted myocardium (chapter 4 and 5, respectively). We suggested a role for intracardiac ACE and renin in infarct healing in the early phase after MI. In this period after MI we observed high levels of AO mRNA in both infarcted and sham animals. The high AO mRNA levels were localized in the epicardium, suggesting an effect of the surgery in both groups of animals.

In this study cardiac AO mANA levels were very low. However, AO may be not rate-limiting and protein levels may be sufficient to produce increased amounts of intracardiac angiotensin /I (ANG II) in different pathological conditions. The ability to synthesize angiotensin | and ANG || in the isolated rat heart, without exogenous AO, but in the presence of exogenous renin, strengthens that suggestion (4).

Others have also found activation of the components of the intracardiac RAS in different models of cardiac hypertrophy. Recently, Boer et al (2) found a more than 40 -fold increase of renin mRNA, 7 days following a volume-overload model in rats. At 1 day after surgery no increase of renin mRNA was observed. In SHA increased cardiac renin mRNA expression was demonstrated (3). In addition, increases of ACE mRNA levels, ACE activity, AT1 a mRNA and angiotensin receptor density have been observed in pressure-overload induced hypertrophy $(1,6,8,10)$.

In summary, this study demonstrates unchanged levels of AO MRNA in the moninfarcted hypertrophied rat heart, as also observed for ACE and renin mRNA in chapter 4 and 5 , respectively. From these data we conclude that the synthesis of intracardiac $A O$ does not play a dominant role in the development of cardiac hypertrophy and in the role of wound healing following $\mathrm{Ml}$ in the rat. Furthermore these data provide further evidence that the intracardiac RAS does not play a dominant role in the development of cardiac hypertrophy after MI in the rat.

\section{REFERENCES}

1. Baker KM, Chernin MI, Wixson SK, Aceto JF. Renin-anglotensin systern involvement in pressureoverioad cardiac hypertrophy in rats. Am / Physiol 1990; 259:11324- H332.

2. Boer PH, Ruzicka M. Lear W. Harmsen E, Rosenthal J, Leenen FHI. Stretch-mediated activation of ciardiac renin gene. Am J Physiol 1994; 267:H1630-H1636.

3. Li C, Prakash O. Re RN. Attered regulation of angiotensinogen gene expression in the left ventricle of the hypertensive rat Circulation $1989 ; 80411-450$. 
4. Lincpaintner $K$, Jin MW, Niedermaier $\mathbb{N}$, Wilhelm MJ, Ganten D. Cardiac angiotensinogen and its locall activation in the isolated perfused beating heart. Circ Res 1990; 67:564-573.

5. Lindpaintner $K$, Lu W, Neidermaier $N$, Schieffer $B$, Just $H$, Ganten D, Drexler $H$. Selective activation of cardiac angiotensinogen gene expression in post-infarction ventricular remodeling in the rat. $J$ Mol Coll Cardiol 1993; 25:133-143.

6. Linz $W$, Scholkens BA, Ganten D. Converting enzyme inhibition specifically prevents the dewelopment and induces regression of cardiac hypertrophy in rats. Clin Exp Hypertens A 1989; $11: 1325-1350$.

7. Sadoshima J, Izumo $S$. Molecular characterization of angiotiensin II--induced hypertrophy of cardiac myocytes and hyperplasia of cardiac fibroblasts. Critical role of the AT1 receptor subtype. Circ Fies 1993; $73 ; 413-423$.

B. Schunkert H, Dzau WJ, Tang SS, Hirsch AT, Apstein CS, Larell BH. Increased rat cardiac angiotensin conwerting enzyme activity and mRNA expression in pressure overload left ventricular hypertrophy. Effects on coronary resistance, contractility, and relaxation. I Clin Invest 1990; 86:1913-1920.

9. Searle PF, Tata RJ. Vitellogenin gene expression in male xenopus hepatocytes during primary and secondary stimulation with estrogen in cell cultures. Cell 1981; 23:741-747.

10. Suzuki d, Matsubara $H$, Urakami $M$, Inada $M$. Rat angiotensin II (type 1A) receptor mRNA regulation and subtype expression in myocardial growth and hypertrophy. Circ Res 1993; 73:439447.

11. Velletri PA, Lovenberg W. Biological regullation of testicular anglotensin $\|$ converting enzyme. Adv Exp Med Biol 1987; 198;487-494. 


\section{CHAPTER 7}

INTRACARDIAC AND SYSTEMIC FEEDBACK REGULATION OF THE RENIN-ANGIOTENSIN-SYSTEM DURING EARLY CAPTOPRIL TREATMENT FOLLOWING MYOCARDIAL INFARCTION IN THE RAT 


\section{ABSTRACT}

In the present study we investigated the regulation of the expression of components of the intracardiac and systemic renin-angiotensin-system (RAS) by interference with the RAS in rats following myocardial infarcition (MI). Wistar rats underwent ligation of the left descending coronary artery, resulting in MI, or a sham-operation. In a second series of experiments animals were treated with the angiotensinconverting-enzyme-inhibitor (ACE-1), captopril $(0.5 \mathrm{mg} / \mathrm{kg} / \mathrm{hr}$ ) from $0-7$ days after sham or Mi-surgery. In all experimental groups rats were sacrificed at 7 days after surgery ( $n=6$ per group) and the heart was removed and divided into right ventricle (RV), septum (SE) and left ventricle (LV). Furthermore lungs, liver and kidneys were removed. Tissues were quickly frozen in liquid nitrogen. Cardiac angiotensinogen $(A O)$, renin, angiotensin 1-converting-enzyme (ACE) and renal renin mRNA levels were quantified by the competitive reverse transcriptase polymerase chain reaction (RT-PCR). Hepatic AO, pulmonary ACE and cardiac atrial natriuretic factor (ANF) mRNA expression were evaluated by the Northern hybridization analysis. At 7 days after $M I$ we found an 8-fold increase of renin mRNA and 3-fold increase of ACE mRNA $(n=6)$ in the infarcted LV, whereas AO mRNA levels were not changed after Mil. No increases of AO, renin and ACE mRNA levels were found in the noninfarcted compartments, whic were hypertrophying as judged from increased ANF mRNA expression. Hepatic AO mRNA levels were not changed following MI. However, renal renin and pulmonary ACE mRNA levels were increased respectively 3 and 1.7-fold following MI. Seven days of captopril treatment had no effect on the intracardiac expression of the RAS components neither in sham nor in infarcted rats. Captopril treatment in sham animals significantly increased renal renin mRNA levels, whereas it had no effect on hepatic AO mRNA and pulmonary ACE MRNA levels. A trend towards an increase in renal renin and hepatic AO mRNA levels was observed in captopril treated infarct animals. The increase of pulmonary ACE mRNA in infarcted animals was suppressed by captopril treatment. These data indicate an activation of the intracardlac and systemic renin and ACE genes, but not of $A O$ following MI. Furthermore, these data suggest differential feedback regulation of the local and systemic RAS in infarcted and sham rats.

\subsection{INTRODUCTION}

Although activation of the intracardiac RAS in experimental heart failure has been established, little is known about its regulation in this condition. Wollert et al. (28) demonstrated increased cardiac ACE mRNA levels after MI. These ACE mRNA levels were not affected by ACE-I treatment for 6 weeks. More is known about the regulation of the systemic RAS in heart failure. An upregulation of renal renin mRNA and a downregulation of pulmonary ACE MRNA have been demonstrated after MI in rats (23). Renal renin mRNA was found to be further increased after treatment with the ACE-I enalapril (21). In contrast hepatic AO mRNA was not influenced by 
experimental $\mathrm{MI}$ and treatment with an ACE-I (21).

In situations other than experimental heart failure, the regulation of the systemic RAS has been studied extensively. Stimulation of $A O$ has been demonstrated following sodium depletion, and treatment with glucocorticoids, estrogens and interleukins $(3,9,26)$. Administration of renin was associated with decreases in plasma $\mathrm{AO}$ and liver AO levels $(16,27)$. Besides renin, also angiotensin II (ANG II) itself influences $A O$ production. ANG $\|$ exerts a positive feedback on hepatic and renal $A O$ gene expression and protein synthesis $(11,22)$. In contrast $A N G \|$ has been shown to exert a negative feedback on renin gene transcription and renal renin secretion $(14,22)$. Sodium deprivation has been demonstrated to increase renal renin MRNA expression (19). In chapter 3 we described an upregulation of renal renin mRNA after short-term captoprill treatment (17). In that chapter we also discussed a differential regulation of $\mathrm{AO}$ mRNA in different tissues, including the atria. We suggested that a balance between the different feedbacks of ANG II and renin may regulate $A O$ mRNA expression. Little is known about the regulation of ACE activity and even less is known about the regulation of the transcription of the ACE gene. ANG II infusion resulted in decreased pulmonary ACE MRNA and ACE activity levels (20). Similarly, increases of pulmonary ACE MRNA and activity were observed after treatment with the ACE-inhibitor quinapril (20). Furthermore, $\beta$ adrenergic stimulation glucocorticoids and androgens were found to stimulate ACE activity in different tissues $(5-7,15)$. An increase as well as a decrease of ACE activity was observed following hypaxia $(10,12)$.

In the present study we investigated the regulation of the intracardiac and systemic renin-angiotensin-systems after experimental MI by early treatment with the ACE-I captopril. At 7 days after MI, intracardiac renin and ACE MFNA levells. were increased, whereas intracardiac AO mRNA was not. None of the intracardiac components of the RAS were influenced by 7 days treatment with captopril in sham and infarcted animals. Renal renin and pulmonary ACE, but not hepatic AO mANA levels were increased after MI when compared to sham animals. Furthermore, we observed suppression of pulmonary ACE mANA and a tendency towards an increase of hepatic $A O$ mRNA levels following captopril treatment in MI animals. These data suggest a differential regulation of the intracardiac and systemic RAS after MI

\subsection{MATERIALS AND METHODS}

\section{Surgery}

Adult male WKY rats were used, weighing $250-300 \mathrm{~g}$ at the beginning of the experiments. Rats underwent induction of $\mathrm{MI}$ (chapter 2.2.1) or sham-surgery. At 7 days after surgery $M I$ and sham rats ( $n=6$ per group) were sacrificed by ether overdose. In a third and fourth group, animals underwent the same surgery as described above. In these groups infarct (MICAP) and sham animals (SHCAP) ( $n=6$ 
per group) received the ACE-1 captopril $(0.5 \mathrm{mg} / \mathrm{kg} / \mathrm{hr})$ for 7 days by osmotic minipumps (chapter 2.2.4).

\section{Tissue processing}

In all animals the heart was removed and a slice of tissue parallel to the base was cut, formalin fixed overnight and paraffin embedded, for measuring infarct sizes (chapter 2.3.1). The rest of each heart was divided in infarcted or non-infarcted (sham) LV, SE and RV. Furthermore, kidneys, liver and lungs were removed. The tissues were subsequently frozen in liquid nitrogen and stored at $-70^{\circ} \mathrm{C}$.

\section{RNA Isolation}

Total RNA was extracted using the LiCl/urea method (24) as described in chapter 2.3.2.

\section{Competitive RT.PCR for angiotensinogen, renin and $A C E$}

The competitive RT-PCA was used for quantification of $A O$, renin and ACE mRNA. The selection of the primers, synthesis of the internal standards, the reverse transcription and the PCR is described in chapter 2.4. The competitive RT-PCR for AO consisted of a double PCR. The first and second PCR of AO were performed at $0.5 \mathrm{~min}$. at $94^{\circ} \mathrm{C}, 0.5 \mathrm{~min}$. at $62^{\circ} \mathrm{C}, 1 \mathrm{~min}$. at $72^{\circ}, 20$ cycles.; the PCR-cycle used for renin was $0.5 \mathrm{~min}$ at $94^{\circ} \mathrm{C}, 0.5 \mathrm{~min}$ at $65^{\circ} \mathrm{C}, 1 \mathrm{~min}$ at $72^{\circ}, 40$ cycles and the PCRcycle used for $\mathrm{ACE}$ was $0.5 \mathrm{~min}$. at $94^{\circ} \mathrm{C}, 0.5 \mathrm{~min}$. at $65^{\circ} \mathrm{C}, 1 \mathrm{~min}$. at $72^{\circ}, 30 \mathrm{cycles}$.

\section{Northern hybridization analysis}

A total of $15 \mu \mathrm{g}$ total RNA from the different compartments of the heart, lung, liver and kidney were used for Northern blotting. The probes used for hybridization were the cDNA inserts to AO (1634 bp) and 28S rRNA (2100 bp) and the PCR-generated probes for ACE and ANF. The $28 \mathrm{~S}$ signal was used as an internal standard, and $A O, A C E$ and ANF signals were related to this 28 s signal (chapter 2.5). Blots containing the total RNA of the compartments of the heart were hybridized with the ANF probe; blots containing total RNA of the lungs and liver were hybridized with the ACE probe and the AO probe, respectively.

\section{Statistical analysis}

All data are presented as mean \pm SEM. Statistical significance was calculated using Kruskal-Wallis test. Statistical significance was accepted at the level of $p<0.05$ (chapter 2.9). 


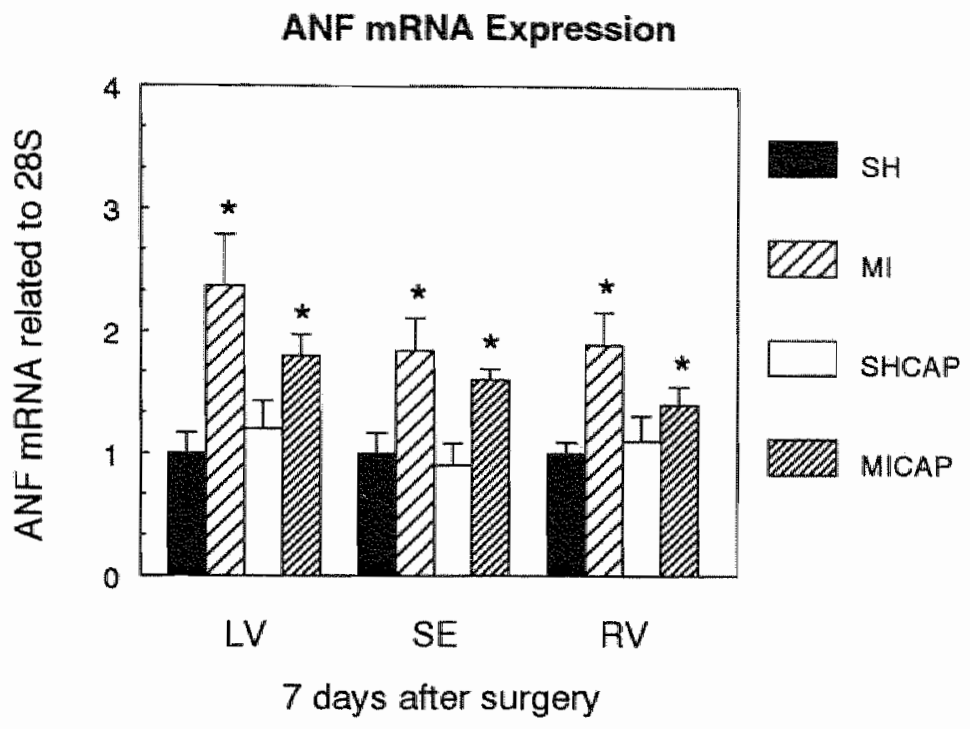

Figure 1. ANF mRNA expression in the left ventricle (LV), septum (SE) and right ventricle (RV) in sham (SH), myocardial infarction (MI), sham treated with captopril (SHCAP) and in myocardial infarction treated with captopril (MICAP). The ANF/28S ratio of sham values was set to the value of $1 .{ }^{*} P<0.05$, significantly different from sham.

\subsection{RESULTS}

\section{Infarct size and ANF MRNA expression}

There was no difference between the mean infarct sizes in the two Ml groups. In the untreated $\mathrm{Ml}$ group mean infarct size was $43 \pm 5 \%(n-6)$, whereas mean infarct size in the captopril treated group was $40 \pm 3 \%(n=6)$. As a marker for cardiac hypertrophy we determined ANF mRNA expression, which increased 2.4-fold in the infarcted LV at 7 days after MI. A 1.8 fold increase of ANF mRNA expression was found in the SE and a 1.9 fold increase in RV, as compared to the ANF mRNA expression in the different compartments of the sham group. In the Mll animals there was a tendency towards decreasing ANF mRNA levels in the different compartments after treatment with captopril, but this was not significant (figure 1).

\section{Angllotensinogen}

Cardiac: AO mRNA was extremely low in sham and infarcted hearts. AO mRNA levels were $438 \pm 104 \mathrm{ag} / 100 \mathrm{ng}$ total RNA in the sham LV, $412 \pm 131 \mathrm{ag} / 100 \mathrm{ng}$ total RNA in the sham SE and $284 \pm 89$ ag/100 ng total RNA in sham RV. No differences in AO mRNA levels were found berween sham hearts and infarcted 


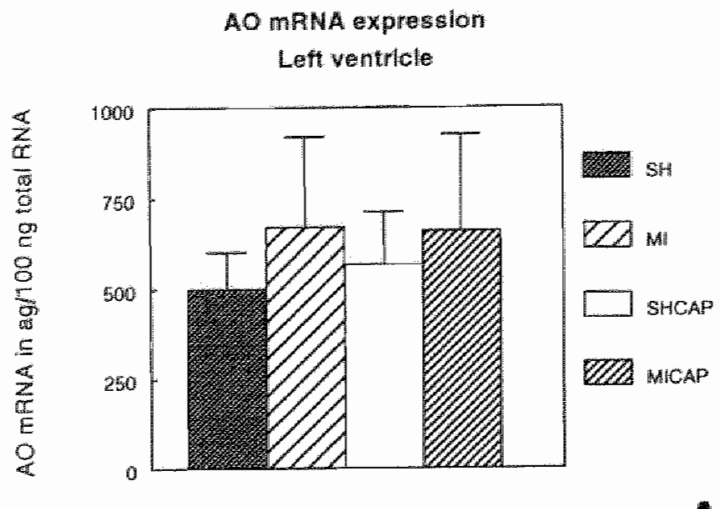

7 days atter surgery

A

AO mRNA expresslon

Septum

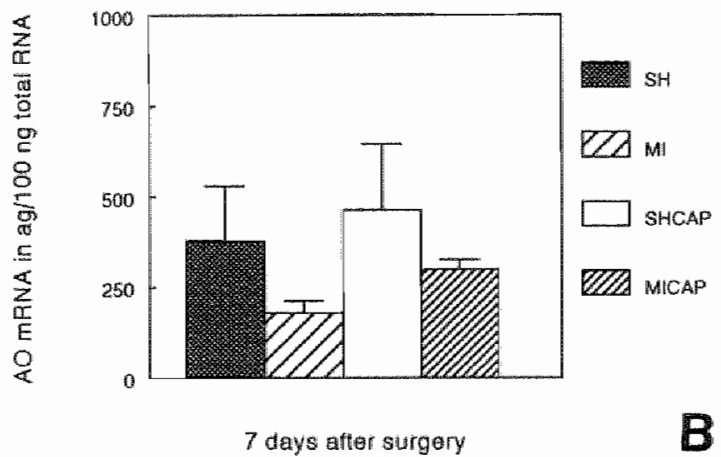

AO MRNA expression

Fight ventricle

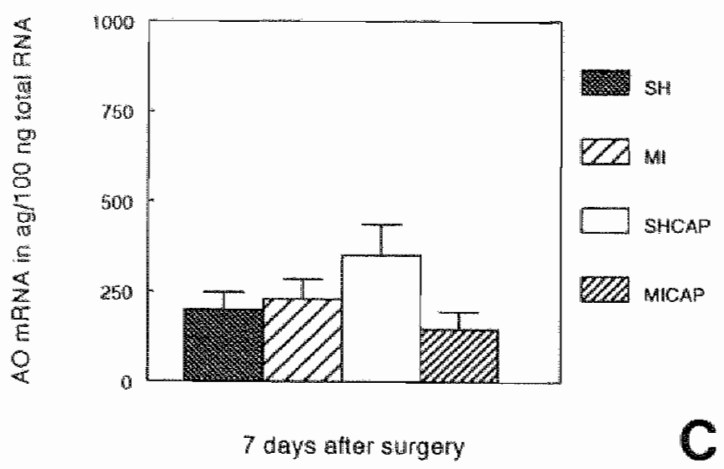

Figure 2. Angiotensinggen (AO) mRNA amount in the left ventricle (A), septum (B) and right ventricle (C) in sham (SH), imyocardial infarction (M), sham treated with captopril (SHCAP) and in myocardial infarction treated with captopril (MICAP). 


\section{Hepatic AO mRNA Expression}

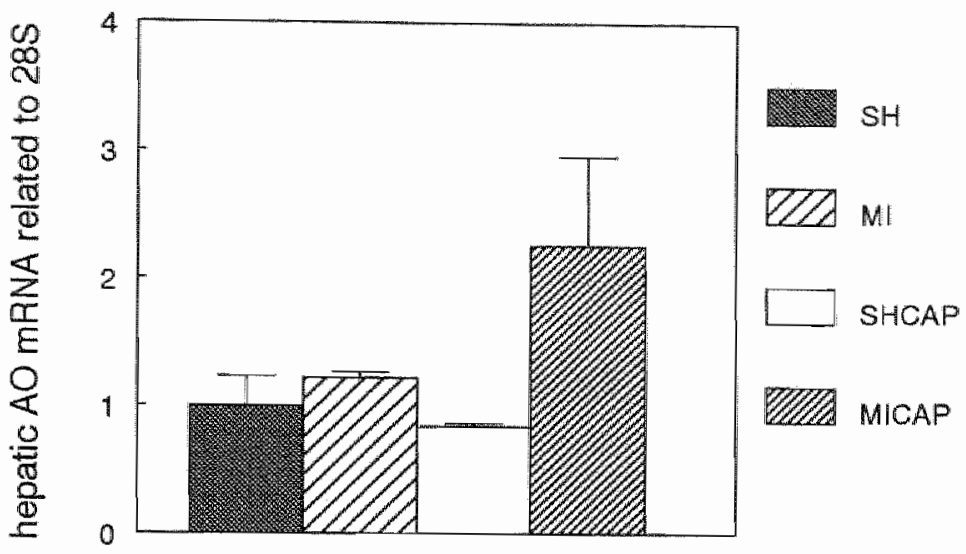

7 Days after surgery

Figure 3. Hepatis angiotensinogen (AO) mRNA expression in sham (SH), myocardial infarction (MI), sham treated with captopril (SHCAP) and in myocardial infarction treated with captopril (MICAP). The AO/28S ratio of sham values was set to the value of 1 .

hearts in any of the compartments. Early captopril treatment in the sham animals as well as the infarcted animals did not affect $A O$ mRNA levels in any of the compartments (figure $2 \mathrm{~A}, \mathrm{~B}$ and $\mathrm{C}$ ).

Hepatic: The ratio of the densitometric values of $A O$ and $28 \mathrm{~S}$ of sham animals was set to the value of 1. AO levels of the MI as well as the SHCAP group were not different from the sham group. However, a trend towards increase of hepatic $A O$ mRNA levels was observed in the MICAP group (2.3-fold), as compared to the MI group (figure 3).

\section{Renin}

Cardiac. Renin mRNA expression was very low in all compartments of the shamhearts at 7 days after surgery. In this group, renin mANA levels were above the level of accurate quantification in only 2 out of 6 left ventricles at 7 days after sham surgery. Reducing the amounts of internal standard did not solve this problem. Mean renin mRNA levels were $2.7 \mathrm{fg} / 100 \mathrm{ng}$ total RNA in the sham LV. In the MI group renin mANA levels were high in the infarcied left ventricles. Mean renin mRNA levels in the 7 day infarcted LV were $22 \pm 6 \mathrm{fg} / 100 \mathrm{ng}$ total RNA, indicating a more than 8-fold increase as compared to sham. In the RV and SE of MI animals 


\section{Renin mRNA expression}

\section{Left ventricle}

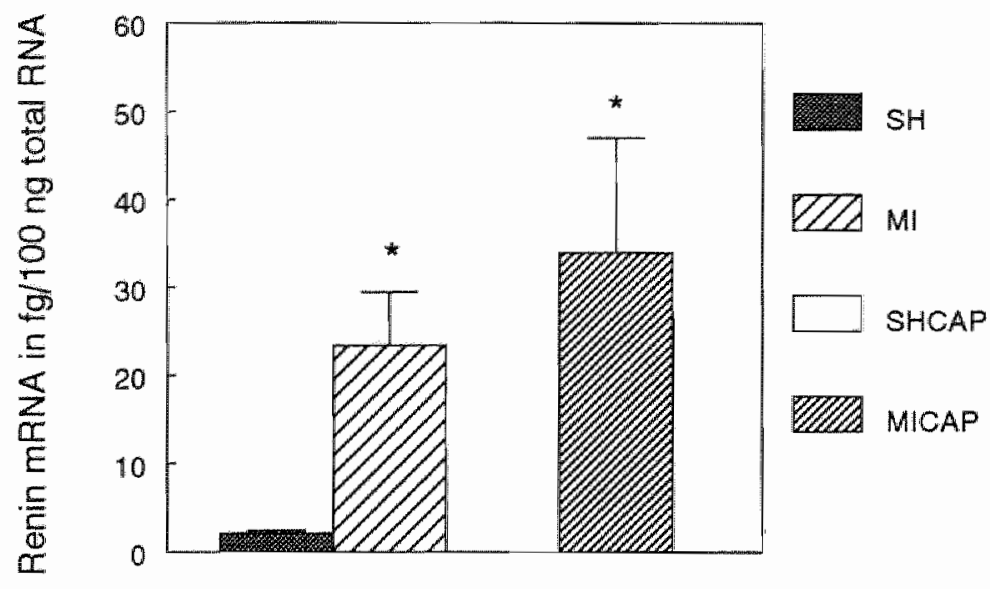

\section{7 days after surgery}

Figure 4: Renin mRNA amount in the left ventricle in sham (SH), myocardiall infarction (MI), sham treated with captopril (SHCAP) and in myacardial infarction treated with captopril (MICAP). "P<0.05, significantly different from sham.

\section{Renal renin mRNA Expression}

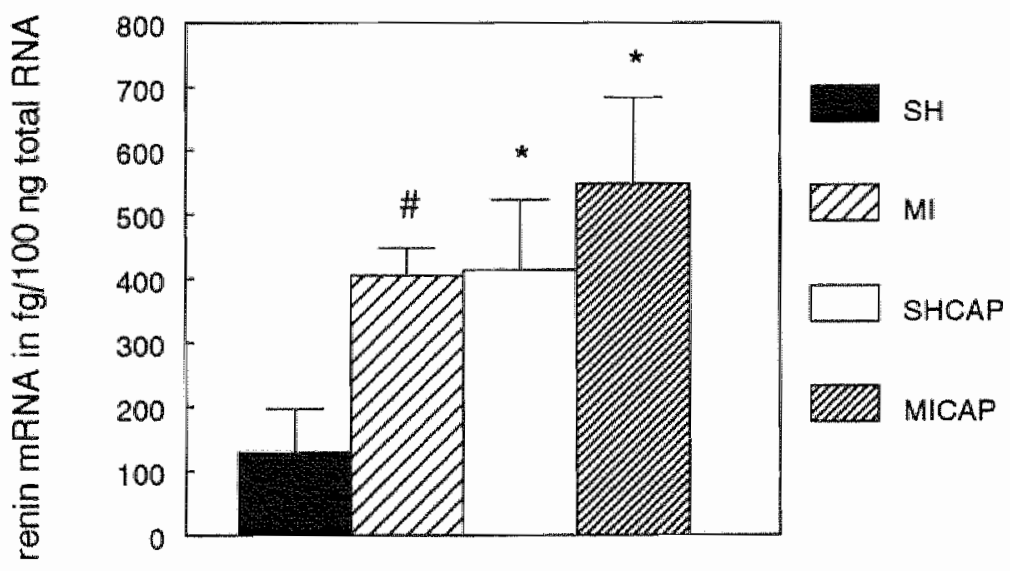

\section{Days after surgery}

Figure 5: Renal renim mRNA amount in sham (SH), myocardial infarction (MD), sham treated with captopril (SHCAP) and in myocardial infarction treated with captopril (MICAP).* $P<0.05$; \# $P<0.01$. significantly different from sham. 
renin MRNA levels were below the level of accurate quantification. Also in the SHCAP group renin mANA levels were not above the level of accurate quantification in any of the compartments. However, in the infarcted LV of animals in the MICAP

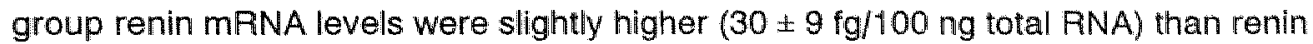
mRNA levels in the LV of the MI group, although these levels were not significantly different (figure 4 ).

Renal: Renal renin mRNA levels were $129 \pm 68 \mathrm{fg} / 100 \mathrm{ng}$ total RNA in the sham group, which indicated that renal renin mRNA levels were at least 50 -fold higher when compared to renin mRNA levels in sham LV. In the Ml group renal renin MANA levels increased 3.1 -fold as compared to the sham group. In the SHCAP there was a 3.2 -foll increase in renall renin mRNA as compared to the untreated sham group. Renal renin mRNA levels in the MICAP group were slightly higher than in the untreated MI group (1.4-fold increase), although this increase was not significantly different (figure 5).

\section{ACE}

Cardiac: In sham-operated rats the mean value of ACE mRNA expression was 383 $\pm 130 \mathrm{fg} / 100 \mathrm{ng}$ total RNA in the LV, $310 \pm 193 \mathrm{fg} / 100 \mathrm{ng}$ total RNA in SE and $567 \pm$ $240 \mathrm{fg} / 100 \mathrm{ng}$ total RNA in the RV. At 7 days after MI ACE mRNA expression increased 3-fold in the infarcted LV when compared to the non-infarcted LV in the sham group. In the infarcted animals no significant change in ACE MRNA expression was observed in the SE and RV. Captopril treatment did not affect ACE mRNA levels in the different compartments of the sham or infarcted rats (figure $6 A$, $B$ and $C)$.

Pulmonary: The ratio of the densitometric values of ACE and 285 of sham animals was set to the value of 1 . In the MI group pulmonary ACE MRNA levels were 1.7fold higher than in the untreated sham rats. Captopril treatment in the sham group did not affect pulmonary ACE mRNA levels. The increase of pulmonary ACE MRNA levels in the MI group was suppressed after captopril treatment (figure 7).

\subsection{DISCUSSION}

The data presented in this study show a difference in the regulation of the expression of components of the cardiac and systemic RAS after captopril treatment in infarcted and sham-operated rats. Intracardiac renin and ACE MRNA Levels were increased after MI, whereas intracardiac AO was not. None of the intracardiac components of the RAS were affected by captopril treatment in sham and infarcted animals. Renal renin and pulmonary ACE MRNA were increased following MI. Hepatic AO mANA expression was not changed following Ml. Captopril treatment resulted in increased renal renin mRNA levels in the sham-group, but had no effect 


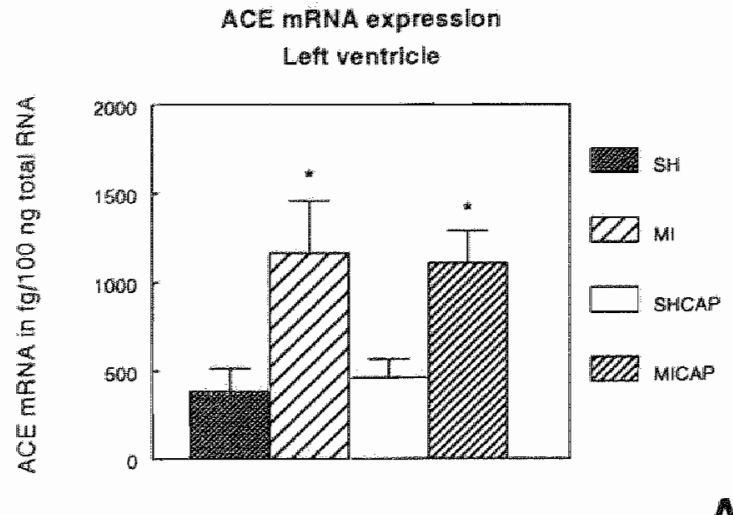

7 days atter surgery

ACE MRNA expression

Septum
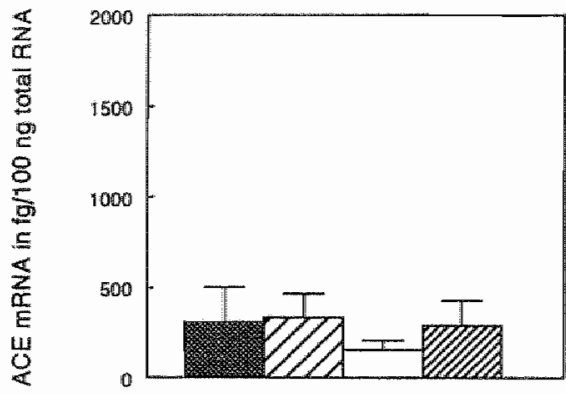

7 days atter surgary

B

ACE MANA Qxpression

Rlght ventricie:

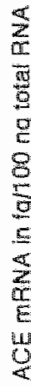

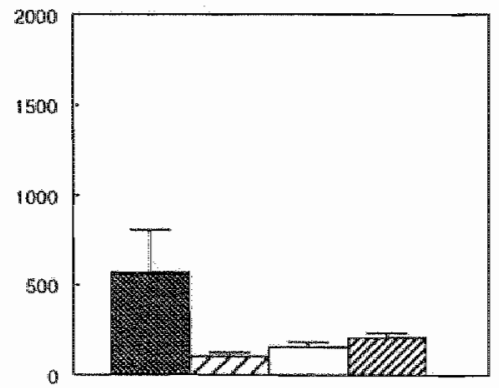

7 days after surgory

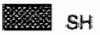

QD M

WOW MICAP
Figure 6. ACE MRNA amotnit in the left ventricle (A), septum (B) and right ventricle (C) in sham (SH), myocardial infarction (MI), sham treated with captopril (SHCAP) and in myacardial infarction treated with captopril (MICAP). * $P<0.05$, significantly different from sham. 


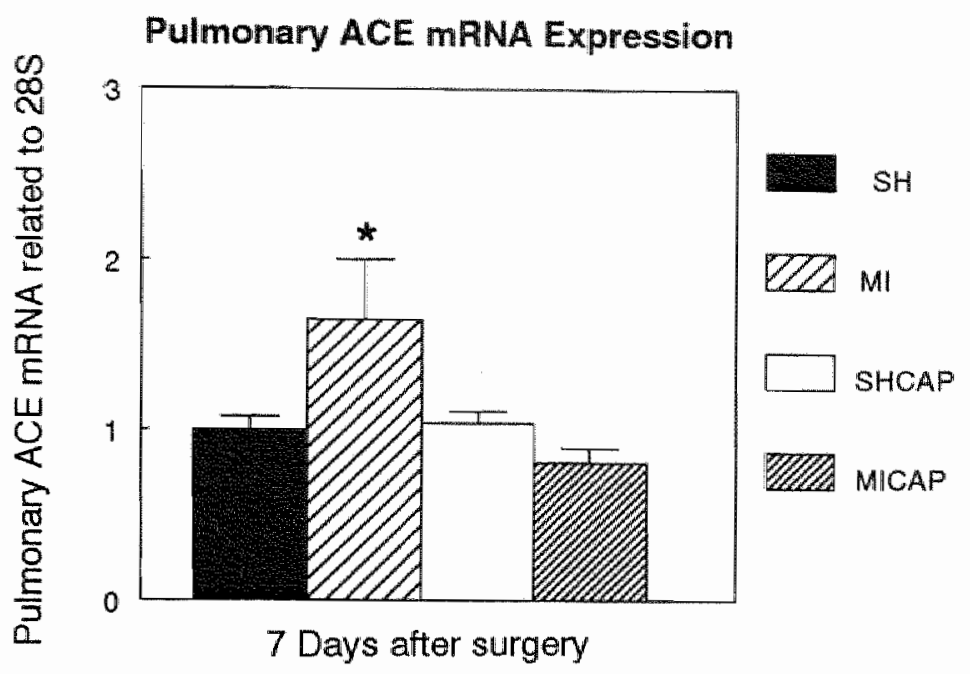

Figure 7. Pulmonary ACE mRNA expression in sham (SH), myocardial infarction (MI), sham treated with captopril (SHCAP) and in myocardial infarction treated with captopril (MICAP). The ACE/28S ratio of sham values was set to the value of 1 . ${ }^{*}<0.05$, significantly different from sham.

on hepatic $A O$ and pulmonary ACE mANA levels. Captopril following MI resulted in suppression of pulmonary ACE mRNA and a trend towards an increase for hepatic $A O$. The renal renin mRNA expression was not affected in captopril treated infarcted animals.

The unchanged levels of cardiac ACE and hepatic AO mRNA and the increased levels of renal renin mRNA after captopril treatment in infarct or sham animals, respectively, are in accordance with data from other studlies. Recently, cardiac ACE mRNA expression was studied after treatment with an ACE-I in infarcted rats. In that study no difference was observed after 6 weeks of treatment with the ACE-I (28). Schunkert et al. (21) found unchanged hepatic $A O$ and renal renin mRNA levels at 12 weeks after MI. After 6 weeks of treatment with the ACE-I enalapril, starting at 6 weeks after $M I$, renal renin mRNA levels increased 2.5-fold, whereas hepatic AO mRNA levels remained unchanged. After 6 weeks of severe heart failure (infarct sizes $\geq 40 \%$ ) increased levels of renal renin mRNA (1,7-fold) were found (23). Pulmonary $\mathrm{ACE}$ mRNA and activity has been demonstrated to decrease after severe MI in the rat (8). In the same study increased levels of plasma ACE activity were observed.

The mechanism for the differential regulation of the intracardiac and systemic RAS in normal and pathophysiological conditions is unclear. Several possibilities have to be considered.

1) Renal renin mRNA levels were elevated after captopril treatment in the sham animals, indicating that low ANG II plasma levels stimulate renal renin gene expression. This feedback was not obsenved for the cardiac renin gene. 
However, cardiac renin mANA levels were extremely low and were not detectable in all hearts. Therefore, we can not totally exclude an upregulation of cardiac renin mRNA after captopril treatment, resulting in cardiac renin MRNA levels, which may be still undetectable for our methods. Because cardiac renin mRNA levels could be quantified in some of the sham animals, but not in the captopril treated sham animals, this possibility is highly unlikely.

2) In the captopril-treated group following MI pulmonary ACE MRNA levels are suppressed, whereas cardiac ACE MRNA levels are still elevated. The increase of ACE MRNA levels in the LV and lungs may result from a difference in controlling ACE mRNA levels. Increased wall tension, stretch, or the direct effect of cell death, releasing stimulating substances, may control mRNA levels of the intracardiac ACE, whereas hemodynamics may play an important role in controlling pulmonary ACE mRNA levels. After MI the controlling mechanism for regulating mRNA levels of the cardiac RAS may overrule the mechanism for controlling the systemic RAS.

The differential regulation of the renin-anglotensin-systems may indicate that the intracardiac and systemic RAS have different functions. Whereas the systemic RAS is thought to be involved in regulation of hemodynamic homeostasis, an activated intracardiac RAS after MI may be involved in wound healing (18) and remodelling of the heart $(13,25)$, as discussed in chapters 4 to 6 of this thesis.

Although cardiac mANA levels of the components of the RAS are not suppressed after ACE-I treatment, ACE-inhibition most probably results in lower cardlac ANIG II levels in the captopril treated than in the untreated Ml group. First the dose of the ACE-I used in this study results in a 17-fold shift in the pressor doseresponse curve to angiotensin I, indicating effective ACE-inhibition (25). Captopril is able to penetrate into the heart and it therefore is unlikely that intracardiac ANG II levels are not suppressed after captopril treatment (4). Moreover, in chapter 3 we observed a dlownregulation of atrial AO mRNA after short-term captopril treatment, suggesting effective cardiac ACE-inhibition.

The mean infarct sizes in the different groups were $43 \%$ and $40 \%$ in the untreatted and treated MI group, respectively. Infarction from this size results in hypertrophy of the non-infarcted myocardium $(1,2)$, as was also shown by the increased levels of ANF, a marker or cardiac hypertrophy. Captopril treatment resulted in suppression of ANF mANA, although this effect was not significant. In our study captopili treatment may have been to short to completely suppress ANF MRNA in infarcted rat hearts. Wollert of al. (28) observed a downregulation of cardiac ANF mANA expression in infarcted rats, 6 weeks after ACE-1 treatment. However, also in that study ANF mRNA expression was not completely suppressed to sham levels (28).

In summary, we found an activation of the intracardiac and systemic renin and ACE after MI. Whereas captopril treatment did not affect the intracardiac RAS mRNA expression, the systemic RAS was alfected by the captopril treatment. These 
data indicate differential regulation of the intracardiac and systemic RAS in normal and pathological conditions.

\section{REFERENCES}

1. Anversa P, Loud AV, Levicky V. Guideri G. Left ventricular failure induced by myocardial infarction. 1. Myocyte hypertrophy. Am J Physiol 1985; 248:H876-H882.

2. Anversa P. Palackal T, Sonnenblick EH, Olivetti G. Meggs LG, Capasso JM. Myocyte cell loss and myocyte cellular hyperplasia in the hypertrophied aging rat heart. Circ Res 1990;67:671-885.

3. Chang $E_{\text {, Perman }}$.J. Multiple hormones regulate angiotensinogen messenger ribonucleic acid levels in a rat hepatoma cell line. Endocrinology 1987; 121:513-519.

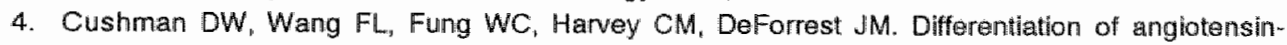
converting enzyme (ACE) inhibitors by their selective inhibition of $A C E$ in physiologically important: target organs. Am $J$ Hypertens $1989 ; 2: 294-306$.

5. Davis $M H_{1}$. Pieringer J. Regulation of dipeptidyl aminopeptidase I and angiotensin converting enzyme activities in cultured murine brain cells by cortisol and thyroid hormone. I Neurochem $1987 ; 48: 447-454$.

6. Friedland $J$, Setton $C$, Silverstein E. Angiotensin converting enzyme: Induction by steroids in rabbit alveolar macrophages in culture. Science 1977; 197:64-65.

7. Fyhrquist $F$, Gronhagen-Riska $C$. Hortling $L$, Forslund $T$, Tikkanen I. Regulation of angiotensin converting enzyme. J Hypertens Suppl 1983; 1:25-30.

8. Huang $H_{1}$, Arnal JF, Llorens-Contes $C$, Challah M, Alhenc-Gelas F, Corvol P, Michel JB. Discrepancy between plasma and lung angiolensin-converting enzyme activity in experimental congestive heart failure. A novel aspect of endothelium dysfunction. Crrc Res 1994; 75:454-461.

9. Ingelfinger $J \mathbb{R}$, Pratt $R E$, Ellison $K$, Dzau $V J$. Sodium regulation of angiotensinogen mRNA expression in rat kidney cortex and medulla. J Clin Inwest 1986; 78:1311-1315.

10. Jin $H$, Oparil $S$, Ann $H S_{n}$ Yang $R$, Jackson $R M$. Hypoxia-induced inhibition of angiotensin converting enzyme activity: Role in vascular regulation. I Appl Physiol 1987; 63:1012-1018.

11. Khayyall M, MacGregor J, Brown JJ, Lever AF, Robertson JIS. Increase of plasma renin-substrate concentration after infusion of angiotensin in the rat. Clin SCI 1973; 44:87-90.

12. King SJ, Booyse FM, Lin PH, Traylor M, Narkates AJ, Oparil S. Hypoxia stimulates endothelial cell angiotensin-conventing enzyme antigen synthesis. Am J Phystiol 1989; 256:C1231-C1238.

13. van Krimpen $C_{\text {s }}$ Smits JFM, Cleutjens JPM. DNA synthesis in the non-infarcted cardiac interstitium is increased after left coronary artery ligation in the rat: effects of captopril. J Mol Cell Cardiol 1991; 23:1245-1253.

14. Naftilan AJ, Oparil S. Inhibition of renin release from rat kidney slices by the anglotensins. Am J Physiol 1978; 235:F62-F68.

15. Nahmod VE, Balda MS, Pirola CJ, Finkelman S, Gejman PV, Cardinali DP. Circadian thylhm and neural regulation of rat pineal angiotensin converting enzyme. Brain Res 1982; 235:216-220.

16. Nasjletti A, Masson GMC. Stimulation of angiotensinogen formation by renin and angiotensin. Proc Soo Exp Biol Med 1973; 142:307-310.

17. Passier PCJJ, Verluyten MJA, Daemen MJAP, Smits JFM. Regulation of angiotensinogen and renin mRNA expression in different tissues of the rat. In: McGregor GA, Sever PS, eds. Current advances in ACE inhibition. v. 3. London: Churchill Livingstone, 1993:150-154.

18. Passier RCuJJ, Smits JFM, Verluyten MJA, Studer R, Drexler $H$, Daemen MJAP. Activation of angiotensin-converting-enzyme expression in the infarct zone following myocardial infarction. Am J Physial 1995; 269:H1268-H1276. 
19. Samani NJ, Morgan K, Brammar WJ, Swales JD. Detection of renin messenger RNA in rat tíssues: increased sensitivity Using an RNAse protection technique. I Hypertens Supp/1987; 5:S19.S21.

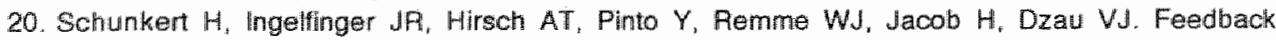
regulation of angiotensin converting enzyme activity and mANA levels by angiotensin II. Circ Res $1993 ; 72: 312-318$.

21. Schunkert H, Ingelfinger JP, Hirsch AT, Tang SS, Litwin SE, Talsness CE, Dzau WJ. Evidence for tissue-specific activation of renal angiotensinogen MANA expression in chronic stable experimental heart faifure. J Clin Invest 1992; 90:1523-1529.

22. Schunkert $H$, Ingelfinger JR, Jacob $H$, Jackson $B$, Bouyounes $B$, Dzau VJ. Reciprocal feedback regulation of kidney angiotensinogen and renin mRNA expressions by angiotensin II. Am J Physiol 1992; 263:E863-EB69.

23. Schunkert H. Tang SS, Litwin SE, Diamant D. Riegger G, Dzau WJ, Ingelfinger JR. Regulation of intrarenal and circulating renin-angiotensin systems in severe heart failure in the rat. Cardiovasc Fes 1993: 27:731-735.

24. Searle PF, Tata PJ. Vitellogenin gene expression in malle xenopus hepatocytes during primary and secondary stimulation with estrogen in cell cultures, Cell 1981;23:741-747.

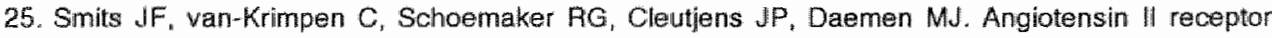
blockade after myocardial infarction in rats: effects on hemodynamics, myocardial DNA synthesis, and interstitial collagen content. J Cardiovasc Pharmacol 1992; 20:772-778.

26. Soden $M$, Klett $C$, Hasmann $T$, Hackenthal $E$. Angiotensinogen: an acute-phase protein? Hypertension 1994; 23 (Suppl):1126-1130.

27. Tateishi $H$, Nasjletti $A$, Masson GMC. Fiole of renin in the regulation of angiotensinogen levels in plasme. Proc Soc Exp Biol Med 1971; 137:1424-1428.

28. Wollert $K C$, Studer $\mathbb{R}$, von Bulow $B$, Drexler $H$. Survival after myocardial infarction in the rat. Role of tissue angliotensin-converting enzyme inthibition. Circulation 1994; 90:2457-2467. 


\title{
CHAPTER 8
}

\author{
GENERAL DISCUSSION
}




\section{B.1 INTRODUCTION}

In this thesis we studied the role of the intracardiac renin-angiotensin-system (RAS) in the development of cardiac hypertrophy. Furthermore we studied its regulation by applying different interventions in the RAS. We found:

A) No activation of the different components of the intracardiac RAS in the hypertrophied myocardium following myocardial infarction (MI), indicating that the intracardiac RAS does not play a dominant role in the development of cardiac hypertrophy following $\mathrm{Ml}$.

B) An activation of the intracardiac renin gene and angiotensin I-converting-enzyme (ACE) gene, protein and activity in the border zone of the infarcted area, suggesting a role for the intracardiac RAS in wound healing.

C) A differential regulation of the RAS in different tissues, and in normal and pathophysiological conditions, suggesting a tissue-specific regulation of the RAS.

\subsection{THE EXISTENCE OF AN INTRACARDIAC RAS}

As discussed in chapter 1, the existence of all components of the intracardiac RAS has been detected $(4,5,12,16,21,28,35)$. A prerequisite for the existence of an intracardiac RAS is the presence of mRNA expression of the different components in the heart. In normal conditions we found a low expression of components of the RAS in the heart. Using conventional techniques, like Northern hybridization analysis, intracardiac mRNA expression of the components of the RAS was not detectable. Therefore, we used a competitive RT-PCR for quantifying low levels of mRNA of these components of the intracardiac RAS (chapter 4-7). Thus this thesis confirms the existence of an intracardiac RAS. Of these components, angiotensinogen (AO) and renin displayed the lowest levels of mRNA.

\subsection{THE INTRACARDIAC RAS VERSUS THE SYSTEMIC RAS}

\section{Physiological conditions}

Circulating components of the RAS may contribute to the intracardiac levels of angiotensin II (ANG II) and vice versa. In sham-operated hearts we observed low MRNA expression of components of the RAS. Although overall expression of ACE was low, it was localized in specific cells (endothelium) and displayed measurable activity. Levels of $\mathrm{AO}$ and renin mRNA were low; immunocytochemical localization was impossible, suggesting simillarly low protein levels. However, since these components are considered to be able to diffuse into the heart (12) they can, in combination with relatively high intracardiac ACE-activity, contribute to intracardiac formation of ANG II. Thus, as is illustrated in figure 1 , under normal 


\section{Interactions between the systemic and intracardiac RAS}
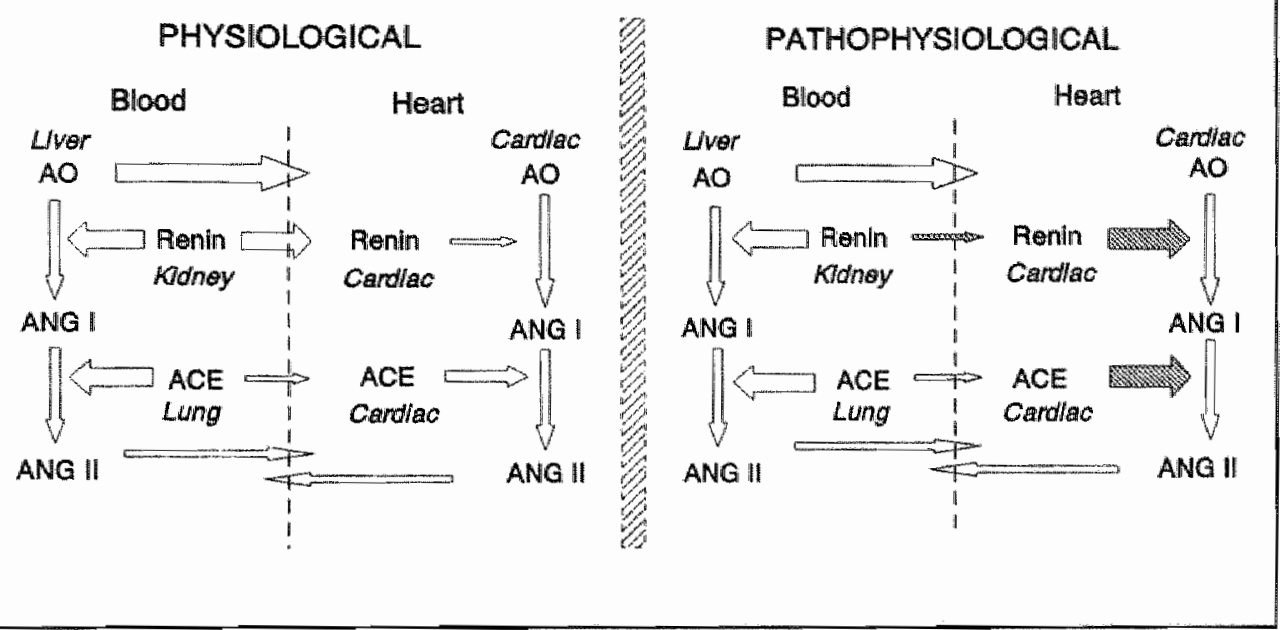

Flgure 1. Interactions between the systemic (blood) and intracardiac (heart) renin-angiotensin-system (RAS) under physiological and pathophysiological conditions. $A O=$ angiotensinogen; $A C E=$ angiotensin I-converting-enzyme; ANG I = angiotensin l; ANG $\|=$ angiotensin $\|$.

conditions interaction between the circulating and intracardiac RAS may contribute to intracardiac ANG II-formation, with emphasis on the circulating RAS.

\section{Pathophysiological conditions}

In chapters 3 to 6 we studied the activation of the intracardiac RAS in pathophysiological situations, like MI and aorta coarctation. A downregulation of atrial AO mRNA was observed following aorta coarctation (chapter 3) whereas no ventricular AO mRNA could be detected by Northern hybridization analysis. Localized activation of the renin gene (chapter 5) and the ACE gene and protein (chapter 4) were found in the early phase following MI in the border zone of the infarcted area, whereas no activation of the cardiac AO gene was found (chapter 6).

Other studies have demonstrated activation of the intracardiac RAS in pathophysiological conditions, like $\mathrm{MI}(11,14,29)$ and pressure- and volume-overload hypertrophy $(1,3,40)$. However activation of the intracardiac renin mRNA following $M I$ has not been demonstrated before. Furthermore, time, site and function of activation of the intracardiac RAS are not clear.

Plasma ANG II (PANG II) levels and plasma renin activity (PRA) are elevated 
after acute MI or aorta coarctation. This activation of the systemic AAS occurs shortly after MI or aorta coarctation. In most studies PANG II levels and PRA are back to base line levels within 5 days (chapter 3), however, in severe heart failure PANG II and PRA may also remain elevated for several weeks $(1,20,36,42)$.

The cardiac AO gene is not activated after MI. This does, however, not rule out increased ANG $\|$-formation. First, cardiac AO levels may be sufficient and not ratelimiting for the formation of angiotensin ( (ANG 1), in spite of the activation of the cardiac renin gene. Second, if cardiac $\mathrm{AO}$ becomes rate-limiting, it may be completely or partly derived from the circulation.

After MI, we demonstrated a clear activation of the renin gene, which is regarded as the rate limiting enzyme. Intracardiac renin mRNA levels after $M \mid$ were only 3 -fold lower than renal renin MANA levels in sham animals (chapter 7), suggesting that the intracardiac renin levels may be high enough for substantial production of ANG I, independently of systemic renin.

As discussed above, we suggested that in sham animals intracardiac ACE activity may be sufficient for the formation of intracardiac ANG II. In the infarcted left ventricle ACE mANA and activity were 3-fold higher than sham levels. The above argued increase of $A C E$ substrate, $A N G$ I, by the activation of the renin gene, may, in fact, induce activation of the ACE gene and protein. With increased ANG I levels, $A C E$ may become rate-limiting. By the activation of $A C E$, the increased ANG I levels can translate into increased ANG II levels. In summary, in pathophysiological situations, like MI, except for the possible diffusion of circulating AO into the heart, the formation of intracardiac ANG || by the other components may be greatly independent on the systemic RAS (figure 1).

\subsection{REGULATION OF THE INTRACARDIAC RAS AND THE SYSTEMIC RAS}

Little is known about the regulation of the intracardiac RAS, in contrast what is known about the regulation of the systemic RAS. The most obvious findings were obtained with steroids $(6,13)$, sodium deprivation, or with injections/infusions of components of the RAS itself, like ANG II and renin $(2,19,22)$. ANG II has been showin to exert stimulatory effect on $A O$ synthesis and release, and an inhibitory effect on renin and ACE release or activity $(41,43)$. Renin has been demonstrated to exert a negative feedback on $A O$ production $(31,51)$.

We observed a differential regulation of AO mRNA in different tissues following interventions in the RAS, like short-term captopril treatment, nephrectomy or aorta coarctation. In chapter 3 it was suggested that a balance between plasma ANG II levels and renin activity may regulate tissue AO MRNA levels, especially in the atria, brain and liver. In addition, renal renin mRNA was upregulated after short-term 


\section{Regulation of the renin-angiotensin-system}
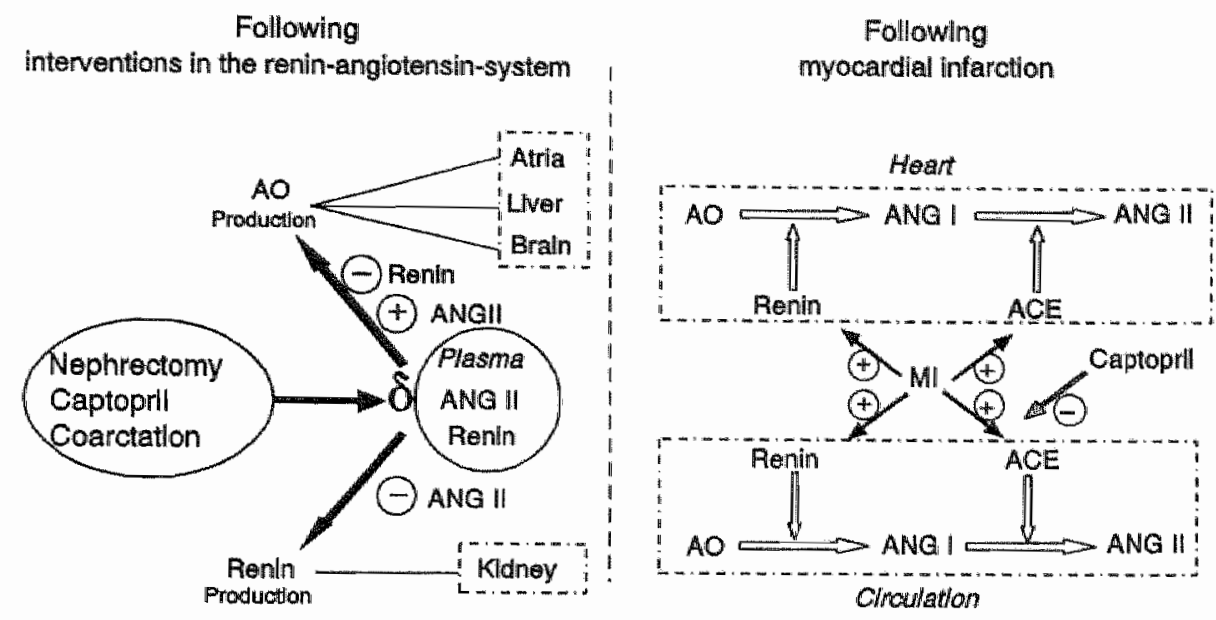

Flgure 2. The regulation of the tilssue and systemic renin-angiotensin-system following interventions in the renin-angiotensin-system or following myocardial infarction. $A O=$ angiotensinogen; $A N G 1=$ angiotensin $\mathrm{l}$; ANG $\|=$ angiotensin $\| ; \delta=$ differences; + $=$ stimulation; - = inhibition.

captopril treatment. This upregulation of renal renin mRNA was also observed in chapter 7 , where seven days of treatment with captopril resulted in an upregulation of renal renin mRNA expression. These data demonstrate that in the normal situation the systemic and some tissue renin-angiotensin-systems, like in atria and brain, may be regulated by the plasma components of the RAS (figure 2). The purpose for this regulation may be to control hemodynamic homeostasis. The feedback on renal renin mRNA expression following captopril treatment is the most effective feedback for restoring ANG II levels, since renin is viewed as the ratelimiting enzyme of the RAS cascade. Levels of the components of the RAS in the ventricles are not affected by captopril treatment in the normal situation. In paragraph 8.3 we already discussed that, under physiological conditions, the intracardiac RAS is dependent on the systemic RAS. Therefore, levels of the components of the cardiac RAS in this situation may be greatly dependent on the regulation of the systemic RAS.

After MI, renal renin and pulmonary ACE MANA levels were increased (chapter 7). The increase of pulmonary ACE mRNA levels after MI, may be a result of the increase of renal renin mANA levels. In that situation ANG I formation may no longer be the rate-limiting step. In response to the increased ANG / levels, pulmonary ACE 
may be upregulated. Captopril treatment in infarcted animals results in a suppression of pulmonary ACE mRNA levels (chapter 7 , figure 2). As discussed in chapter 8.3, the intracardiac RAS after MI, may be greatly independent of the systemic AAS. The intracardiac MRNA levels of components of the RAS are not changled after seven days of captopril treatment in infarcted rats (chapter 7). Renin and ACE genes are still activated, whereas AO mRNA levels are still low. These data indicate a differential regulation between the intracalidiac and systemic RAS and may furthermore indicate differential functions of the intracardiac and systemic RAS.

The possibility exists that the observed lack of regulation of the components of the intracardiac RAS depends upon a lack of inhibition of intracardiac ACE-activity. This is, however, not likely, because the dase of the ACE-I used in this thesis causes a 17 -fold shift of the pressor-dose response curve to ANG I, indicating effective inhibition of the ACE-I (46). Furthermore, captopril is able to diffuse into the heart (10), as also suggested by the inhibition of atrial AO mRNA expression following short-term captopril treatment (chapter 3 ).

\subsection{POSSIBLE FUNCTIONS OF THE INTRACARDIAC RAS AFTER MYOCARDIAL INFARCTION}

Although the intracardiac RAS is activated in models of cardiac hypertrophy, and angiotensin II (ANG II) itself is seen as a growth factor, the role of the intracardiac RAS in the development of cardiac hypertrophy may not be its most important role. Localized activation of renin and ACE around the infarct, but not in the hypertrophied non-infarcted compartments of the heart supports this hypothesis. Also athers have observed the most pronounced effects on the activity of the components of the RAS in the infarcted left ventricle. However, in these studies increased activity of the components of the RAS was also found in the hypertrophied non-infarcted myocardium. Activation of the intracardiac RAS in the other compartments of the heart by others may be explained by the use of less accurate techniques than the competitive RT-PCR, different preparation of the heart tissue, or differences in the experimental protocols. First, a semi-quantitative PCR as performed by Hirsch et al. (20) " makes it difficult to observe differences in mRNA expression due to the introduction of a higher variance in the results by this technique. For instance, observed differences may be explained by differences in efficiency of amplification during PCR. Second, because activation of the intracardiac RAS occurs around the infarcted zone it is possible that large infarctions expand to the right ventricle or septum, thereby increasing the mANA levels of the RAS genes in these tissues. Third, ACE binding has been demonstrated to be associated with reparative fibrosis, which occurs around the necrotic area of the infarct (49). Reparative fibrosis may also occur in the non-infarcted myocardium. However, we never observed reparative fibrosis in the non-infarcted myocardium. These differences may depend upon ventilation of the animals during surgery. Lack 
of ventilation during surgery may cause small focal ischemic areas in the "noninfarcted" septum and right ventricle, resulting in reparative fibrosis. This may explain the increased ACE binding in the non-infarcted myocardium in studies, in which ventilation during surgery did not take place. In this thesis we concluded that the intracardiac RAS does not play a dominant role in the development of cardiac hypertrophy after MI. However, we can not exclude that the activated components of the intracardiac RAS, leading to increased levels of ANG II, may, by diffusion or in combination with the circulating RAS, still play a part in the hypertrophic response of the non-infarcted myocardium.

So, if the intracardiac RAS does not play a dominant role in the development of cardiac hypertrophy after MI, what, if any, is then the function of the Intracardiac RAS? The site of activation of the components of the intracardiac RAS around the necrotic area after MI may provide an answer to this question. Renin mRNA was found in close association with the infarcted area, while expression in the noninfarcted myocardium was very low (chapter 5). Although ACE MRNA was also found around the infarct, ACE mRNA expression could be localized predominantly in endothelial cells (chapter 4). It has been demonstrated that all components of the RAS are expressed in the different cells of the heart, like myocytes, fibroblasts and endothelial cells. In this thesis, none of the components of the RAS displayed mRNA expression in the cardiomyocytes. Activation of both these components of the intracardiac RAS were found to be activated in the same area, around the vicinity of the infarct area. This suggests that the intracardiac RAS acts in a paracrine or autocrine way, leading to the formation of intracardiac ANG II. ACE, the final enzyme of the RAS cascade, is predominantly localized in endothelial cells, which suggests that the formation of ANG I| mainly occurs on the endothelial cells. ANG II formation on or in the vicinity of the endothelial cells may result in proliferation of the endothelial cells. Proliferation of endothelial cells indicates the formation or outgrowth of blood vessels, i.e. neovascularization and angiogenesis. Stoll et al. (48) demonstrated an antiproliferative action of ANG II, mediated via the AT2 receptor, in cultured coronary endothelial cells. However, an angiogenic effect of ANG II has been described in the chorioallantoic membrane $(26,27)$. Furthermore also in the kidney and cornea ANG II was able to induce formation of new blood vessels (15). Recently, Nelissen-Vrancken et al. (32) demonstrated a complete normalization of maximal coronary flow, an indicator for capillary capacity, in the infarcted left ventricle, within 35 days after $\mathrm{MI}$, suggesting vessel growth or dilatation of preexisting vessels in the region adjacent to the infarcted zone. This response could be inhibited by captopril treatment (Nelissen-Vrancken, submitted).

In addition to its effect on endothelial cells ANG II may also influence other cells, like (myo)fibroblasts. The activation of the renin and ACE genes may occur in these (myo)fibroblasts (chapter 4 and 5). Stimulation of fibroblasts by ANG II results in proliferation of these fibroblasts and synthesis of extracellular matrix components $(9,39)$. Appearance of (myo)fibroblasts around the necrotic area has been described in human infarcts (55). Components of the ECM, like collagen I and III and 
fibronectin are activated in the infarcted left ventricle in the early phase after $\mathrm{MI}$ $(8,44)$. In addition ACE-I results in suppression of the increased deposition of ECM components after MI (25). This suggests that the intracardiac RAS may also be involved in formation of fibrous tissue in the infarcted left ventricle, leading to cardiac stiffening and depressed cardiac function (53).

Furthermore, the intracardiac RAS may stimulate the synthesis of ECM components in fibroblasts as a part of the wound healing process. In addition to the role of ECM components in cardiac fibrosis, ECM components also play an important role in wound healing. Growth factors, like PDGF and TGF $\beta$ stimulate the production of components of the ECM $(17,30)$. Additionally, TGF $\beta$ has been found around the infarct area $(52,54)$. ANG II has been found to activate the expression of these growth factors in different cells, including fibroblasts. Therefore, an activated intracardiac RAS may activate the production of ECM components directly, or indirectly via growth factors in fibroblasts, and thereby playing a role in the process of wound healling.

\subsection{THE TRIGGER FOR THE ACTIVATION OF THE INTRACARDIAC RAS AFTER MYOCARDIAL INFARCTION}

Although the activation of the intracardiac RAS after MI is now established, it is not clear what the trigger is for activation of the intracardiac RAS after MI. Several factors, like increased left ventricular end diastolic pressure (LVEDP), stretch, hormonal factors or myocyte necrosis have been suggested to trigger the intracardiac RAS $(29,37)$. In chapter 4 and 5 we demonstrated the localized increase of renin and ACE mRNA's around the infarcted area. This specific localization suggests that a circulating substance is not a trigger for the activation of the intracardiac RAS, since than a more homogeneous activation of the intracardiac RAS would be expected. That a circulating factor, like ANG II, does not play an important role in the activation of the intracardiac RAS is supported by the findings in chapter 7. Captopril treatment, which reduces ANG || levels, did not result in suppression of the activated RAS.

MI results in thinning of the left ventricular wall by the necrotic area and the side to side slippage of the myocytes. In addition, LVEDP is increased after MI. Therefore, accordance to LaPlace's law, wall tension can be expected to be higher in the infarcted left ventricle. Furthermore, the loss of viable cells in MI is associated with an increased risk of aneurysm (the outward bulging of the thinned myocardium), increasing the stretch of cells surrounding the necrotic area. In accordance, stretched myocytes in vitro released ANG $\|(37)$.

The activation of the intracardiac RAS around the necrotic area also suggests that the RAS may be triggered by a direct effect of the necrotic area, like the release of different stimuli from dead myocytes or hypoxia. Not only activation of the RAS has been demonstrated following hypoxia (24), but hypoxia also induces vascular growth (45). It is not known whether this response is mediated via ANG II. 


\subsection{CONCLUSIONS AND FUTURE OUTLOOK}

Experimental and clinical studies demonstrated the beneficial effects of ACE-1 treatment in cardiovascular diseases. Decreased morbidity and mortality rates were evident after ACE-I treatment in these studies $(18,23,33,34,47)$. However, ACE-1 treatment in the early phase after $M i$ resulted in less consistent data when compared with delayed ACE-I treatment $(38,50)$, although recent large clinical studies demonstrated a decrease of the morbidity rate even after early captopril treatment in patients with $M I(7,23)$. We observed an activated intracardiac and systemic RAS in the early phase after M! (chapter 4-7). Although an activated RAS in $\mathrm{MI}$ may be a compensatory response to improve the circulation, in the end it may stimulate further progression of heart faillure.

Captopril treatment resulted in suppression of the systemic RAS, but it had no effect on the activated cardiac RAS in infarcted rats. However, this does not exclude suppression of intracardiac ANG II levels after captopril treatment; since captopril is able to penetrate cardiac tissue (10), most probably cardiac ANG II levels are lower in captopril treated infarcted animals than in untreated infarcted animais. Detrimental effects observed after early ACE-I treatment may be explained by interference with the infarct healing process, through decreased cardiac ANG II levels. Alternatively, if intracardiac ANG II levels are not decreased after captopril treatment, structural and functional effects observed after ACE-I treatment, as discussed in the introduction (chapter 1), may be the result of inhibition of the systemic RAS.

In conclusion, the intracardiac RAS does not play a predominant role in the development of cardiac hypertrophy after MI. Furthermore, it may play a role in wound healing in infarcted rats. The increased systemic RAS may be responsible for the hypertrophic response of the myocardium after MI. Therefore, assuming that the intracardiac RAS has a beneficial role after MI, a possible treatment of patients after $\mathrm{MI}$, may be a combination of suppressing the systemic RAS, but not the intracardlac RAS, thereby suppressing cardiac hypertrophy and leaving the wound healing process intact. Cushman et al. (10) demonstrated that differences in physicochemical properties of ACE-inhibitors results in different patterns of inhibition of plasma- and tissue-ACE (including cardiac ACE). Thus, the outcome of the treatment may depend upon the choice of the ACE-I. It is difficult to predict differences from Cushman's data, because he only studied the effects of single injections. Our hypothesis does, however, warrant more extensive characterization of cardiac ACE-activity during chronic ACE-I treatment.

\section{REFERENCES}

1. Baker KM, Chermin MI, Wixson SK, Aceto JF. Renin-angiatensin system involvement in pressurooverioad cardiac hypentrophy in rats. Am J Physiol 1990;259:4324-11332. 
2. Ben-Ari ET, Garrison $J C$. Regulation of angiotensinagen mRNA accumulation in rat hepatocytes. Am J Physiol 1988; 255:E70-E79.

3. Boer PH, Ruzicka M, Lear W. Harmsen E, Rosenthal J, Leenen FHH. Stretch-mediated activation of cardiac renin gene. Am U Physiol 1994; 267:H1630-H1636.

4. Brownfield $M S$, Reid $I A$, Ganten $D$, Ganong WF. Differential distinction of immunoreactive angiotensin and angiotensin-converting enzyme in rat brain. Neuroscience 1982; 7:1759.

5. Campbell DJ. Circulating and tissue angiotensin systems. J Clin Huest 1987; 79:1-6.

6. Chang E, Perlman AN. Multiple hormones regulate angiotensimogen messenger ribonucleic acid levels in a rat hepatoma cell line. Endocrinology $1987 ; 121: 513-519$.

7. Chinese Cardiac Study Collaborative Group. Oral captopril versus placebo among 13634 patients with suspected acute myocardial infarction: interim report from the Chinese Cardiac Study (CCS1). Lancet $1995 ; 345: 686-687$.

B. Cleutjens JPM, Verluyten MJA, Smits JFM, Daemen MJAP. Collagen remodeling after myocardial infarction in the rat heart. Am J Pathol 1995; 147:325-338.

9. Crawford DC, Chobanian AV, Brecher $P$. Angiotensin III induces fibronectin expression associated with cardliac fibrosis in the rat. Clrc Res 1994; 74:727-739.

10. Cushman DW, Wang $\mathrm{FL}$, Fung WC, Harvey $C M$, DeForrest JM. Differentiation of angiotensinconverting enzyme (ACE) inhibitors by their selectiwe inhibition of $A C E$ in physiologically important target organs. Am J Hypertens 1989; 2:294-306.

11. Danilov SM, Chumachenko PV, Andreeva W, Printseva OY, Lacis RV. Angiotensin converting enzyme expression in the inflammation zone of human myocardial infarction and rat model of skin injury. J Hypertens Suppl 1993; 11 (Suppl. 5):S232-S233.

12. Dzau VJ. Circulating versus local renin-angiotensin system in cardiovascular homeastasis. Circulation 1988; 77 (Suppl. 1):1-4-1-13.

13. Ellison $K E$, Ingelfinger $J A_{*}$ Pivor $M$, Dzau $W$. Androgen regulation of rat renal angiotensinogen messenger RNA expression. J Clin Invest 1989; 83:1941-1945.

14. Fabris B, Jackson B, Kohzuki M, Perich R, Johnston Cl. Increased candiac angiotensin-converting enzyme in rats with chronic heart failure. Clin Exp Pharmacoll Physiol 1990; 17:309-314.

15. Fernandez LA, Casride VJ, Twickler J. Renin-angiotensin and development of collateral circulation after renal ischemia. Am J Physiol 1982; 243:HB69-H875.

16. Ganten $D$, Hermann $K$, Unger $T$, Lang RE. The tissue renin-angiotensin systems: focus on brain anglotensin, adrenal gland and arterial wall. Chin Exp Hypertens $A$ 1983; 5:1099-1118.

17. Gibbons GH, Pratt RE, Dzau VJ. Vascular smooth muscle cell hypertrophy vs hyperplasia. Autocrine Transtorming Growth Factor-betal expression determines growth response to angiotensin II. J Clin invest 1992; 90:456-461.

18. Hall AS, Winter C, Bogle SM, Mackintosh AF, Murray GD, Ball SG. The Acute Infiarction Ramipril Efficacy (AIRE) Study: rationale, design, orglanization, and outcome definitions. J Cardiovasc Pharmacol 1991; 18 (Suppl. 2): $\$ 105-\$ 109$.

19. Herrmann $\mathrm{HC}_{1}$ Morris $\mathrm{BJ}$ "Reid IA. Effect of angiotensin $\|$ and sodium depletion on angiotensinogen production. Am J Physiol 1980; 238:E145-E149.

20. Hirsch AT, Talsness CE, Schunkert $H$, Paul M, Dzau VN. Tissue-specific activation of cardiac angiotensin converting enzyme in experimental heart failure. Circ Res 1991; 69;475-482.

21. Inagami $T$. Penin in the brain and neuroblastoma cells: an ondogenous and intracellular system. Neuroendocrinology 1982; 34:475-483.

22. Ingelfinger $\mathrm{J} A$. Pratt RE, Ellison $K_{s}$ Dzau $V J$ sodium regulation of angiotensinogen mRNA expression in rat kidney cortex and medulla. $J$ Clin invest 1986; 78:1311-1315. 
23. ISIS-4 (Fourth International Study of Infarct Surwhal) Collaborative Group. ISIS-4: a randomized factorial trial assessing early oral captoprit, oral mononitrate, and intravenous magnesium sulphate in 58050 patients with suspected acute myocardial infarction. Lancet 1995; 345;669-685.

24. King SJ, Booyse FM, Lin PH, Traylor M, Narkates AJ, Oparil S. Hypoxla stimulates endothellal cell angiotensim-conwerting enzyme antigen synthesis. Am y Physiol 1989; 256:C1231.C1238.

25. van Krimpen C, Smits JFM, Cleutiens JPM. DNA synthes is in the non-infarcted cardiac interstitum is increased after left coronary artery ligation in the rat: effects of captopril. J Mol Cell Cardiot $1991: 23: 1245-1253$.

26. Le-Noble FA, Hekking JW, Van-Straaten HW, Slaaf DW, Struyker-Boudier HA. Angiotensin II stimulates angiogenesis in the choriomallantoic membrane of the chick embryo. Eur J Pharmacol $1991: 195: 305-306$.

27. Le-Noble FA, Schreurs NH, van-Straaten HW, Slaaf DW, Smits JF, Rogg H, Struijker-Boudier HA. Evidence for a novel angiotensin II receptor involved in angiogenesis in chick emibryo chorioallantoic membrane. Am J Physiol 1993; 264:R460-R465.

28. Lindpaintner $K$ Jin $M$, Wilhelm MJ, Suzuki F, Linz $W$, Scholkens BA, Ganten D. Intracardiac generation of angiotensin and its physiologic role. Circulation 1988; 77:118-123.

29. Lindpaintner $K$, Nedermaier $N$, Drexler $H$, Ganten $D$. Left ventricular remodeling atter myocardial infarction: does the cardiac renin-angiotensin system play a role? I Cardiovaso Pharmacol 1992: 20 Suppl $1: S 41-\$ 47$.

30. Naftilan AJ, Pratt RE, Dzau VJ. Induction of platelet-derived growth factor A-chain and c-myc gene expressions by angiotensin II in cultured rat vascular smooth muscle cells. I Clin Invest 1989; 83:1419-1424.

31. Nasjletti $A_{1}$ Masson GMC. Stimulation of angiotensinogen formation by renin and angiotensin. Proc Soc Exp Biol Med 1973; 142:307-310.

32. Nelissen-Vrancken HJMG, Debets JJM, Snoeckx LHEH, Daemen MUAP, Smits JFM. Time-related normalization of maximal coronary flow in isolated perfused hearts of rats with myocardial infarction. Circulation 1995:(in press).

33. Pfeffer $J M_{1}$ Pfeffer MA. Angiotensin converting enzyme inhibition and ventricular remodeling in heart failure. Am I'Med 1988; 84:37-44.

34. Pfeffer JM, Pfeffer MA, Braunwald $E$. Influence of chronic captopril therapy on the infarcted left ventricle of the rat. Circ Res 1985: 57:84-95.

35. Philips MI, Stenstrom B. Angiotensin II in the rat brain comigrates with autheritic angiotensin II in high pressure liquid chromatography. Circ Res 1985: $56: 212$.

36. Pinto $Y M_{*}$ de-Smet $B G$, van-Gilst WH, Scholtens $E$, Monnink $S$, de-Graeff PA, Wesseling $H$. Selective and time related activation of the cardiac renin-angiotensin system after experimental heart failure: rellation to wentricular function and morphology. Cardiovasc Res 1993; 27:1933-1938.

37. Sadoshima J, Xu $Y$, Slayter $\mathrm{HS}_{\mathrm{q}}$ Izumo S. Autocrine release of anglotensin II mediates stretchinduced hypertrophy of cardlac myocytes in vitro. Cell 1993; 75:977-984.

38. Schoemaker RG, Debets JJM, Struyker-Boudier HAJ. Smils JFM. Delayed but not immediate captopril therapy improves cardiac function in conscious rats, following myocardial infarction. $J$ Mol Cell Cardiol 199:; 23:187-197.

39. Scharb W, Booz GW, Dostal DE, Conrad KM. Chang KC, Baker KM. Angiotensin II is mitoganic in neonatal rat cardiac fibroblasts. Circ Aes 1993; 72:1245-1254.

40. Schunkert $H$, Dzau VJ, Tang SS, Hirsch AT, Apstein CS, Lorell BH. Increased rall cardiac angiotensim converting enzyme activity and mANA expression in pressure overioad left ventricular hypertrophy. Effects on coronary resistance, contractility, and relaxation. I Clin Invest 1990; $86: 1913-1920$ 
41. Schunkert $H$, Ingelfinger JR, Hirsch AT, Pinto $Y$, Remme WJ, Jacob H, Dzau VJ. Feedback regulation of angiotensin converting enzyme activity and $M P N A$ levels by angiotensin II. Circ Res $1993 ; 72: 312-318$.

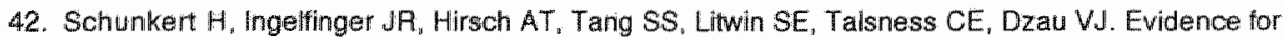
tissue-specific activation of renal angiotensinogen miNA expression in chronic stable experimental heart fallure. If Cho Invest 1992; 90:1523-1529.

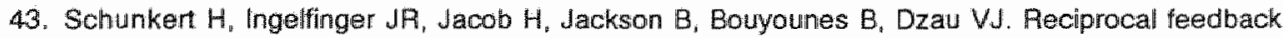
regulation of kidney angiotensinogen and renin mRNA expressions by angiotensin II. Am J Physiof 1992: 263:E863 E869.

44. Shekhonin BV, Guriev SB, Irgashev SB, Koteliansky VE. Immunofluorescence identification of fibronectin and fibrinogen/fibrin in experimental myocardial infarction. $J$ Mol Cell Cardiol 1990; 22:533-541.

45. Shweiki $D$, Itin $A$, Soffer $D$, Keshet $E$. Vascular endothelial growth factor induced by hypoxia may mediate hypoxia-initiated angiogenesis. Nature 1992; 359:843-845.

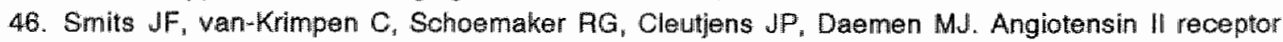
blockade after myocardial infarction in rats: effects on hemodynamics, myocardial DNA synthesis, and interstitial collagen content. J Cardiovasc Pharmacol 1992; 20:772-778.

47. The SOLVD investigators. Effect of enalapril on survival in patients with reduced left ventricular ejection fractions and congestive heart failure. N EngJ J Med 1991; 325:293-302.

48. Stoll M. Steckelings M. Paul M. Bottari SP, Metzger R, Unger T. The angiotensin AT2-receptor mediates inhibition of cell proliferation in coronary endothelial cells. $J$ Clin Invest 1995; 95:651657.

49. Sun $Y$, Ratajska A, Zhow $G$, Weber $K T$. Angiotensin-converting enzyme and myocardial fibrosis in the rat receiving angiotensin $\|$ or aldosterone. $J$ Lab Clin Med 1993; 122:395-403.

50. Swedberg $K$, Held $P$, Kjekshus $J$, Rasmussen $K$, Ryden $L$, Wedel $H$. on behalf of the CONSENSUS $\|$ i. Effects of the early administration of enalapril on mortality in patients with acute myocardial infarction. N Engl / Med 1992; 327:678-684.

51. Tateishi $H$, Nasjletti $A$, Masson $G M C$. Role of renin in the regulation of angiotensinogen levels in plasma. Proc Soc Exp Blol Med 1971; 137:1424-1428.

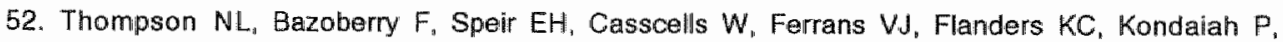
Geiser AG, Sporn MB. Transforming growth factor beta-1 in acute myocardial infarction in rats. Growth Factors 1988; 1:91-109.

53. Weber KT, Brilla CG. Campbell SE "Guarda SE, Zhou G, Sriram K. Myocardial fibrosis: role of angiotensin II and aldosterone. 1993; 88 (suppl. 1):107-124.

54. Willems IEMG. The interstitium in myocardial infarction and hypertrophy. Experimental and clinical observations [Dissertation]. Uniwersity of Limburg, Maastricht, 1995.

55. Willems IEMG, Havenith MG, De Mey JGR, Daemen MJAP. The alpha-smooth muscle actinpositive cells in healing human myocardial scars. Am J Pathol 1994; 145:868-875. 


\section{SUMMARY}

Cardiac hypertrophy is a risk factor for cardiovascular compllications and results in a higher morbidity and mortality. Myocardial infarction (MI) or hypertension are important determinants for the development of cardiac hypertrophy. The intracardiac renin-angiotensin-system (RAS) is thought to play a role in the development of cardiac hypertrophy. In this thesis, experiments were performed to study the intracardiac RAS in the development of cardiac hypertrophy. Furthermore the regulation of the RAS was studied in physiological and pathophysiological conditions.

In chapter 3 the regulation of the mRNA of angiotensinogen (AO) and renin, two components of the RAS, was studied in different tissues, following aorta coarctation (7 days), billateral nephrectomy (24 hours) and captopril treatment (24 hours) in Wistar Kyoto $(\mathrm{WKY})$ rats. These different experimental groups were chosen, because of their different effects on the systemic RAS. Each experiment resulted in different plasma levels of renin and angiotensin II (ANG II), two important modulators in the regulation of $A O$ and renin production. Furthermore, aorta coarctation results in cardiac hypertrophy and therefore the role of intracardiac $A O$ and renin in the development of cardiac hypertrophy following aorta coarctation could be studied. Nephrectomy significantly increased AO mRNA in the liver and the brain, whereas it had no effect on other tissues examined. Renin mRNA expression following nephrectomy was not affected in any of the tissues examined. Both aorta coarctation and captopril treatment resulted in a downregulation of atrial AO mANA. However, no difference of AO mRNA expression was observed in the other tissues following aorta coarctation or captopril treatment. Again renin mRNA expression was not affected in any of the tissues examined following arta coarctation. In addition, renal renin mRNA expression was increased after captopril treatment. From these data, we concluded that $A O$ and renin mRNA are differently regulated in the tissues examined. AO mRNA in the liver and brain appears to be tonically inhibited by renin, whereas AO mRNA in the atria is not. $A$ negative feedback of renin mRNA expression by ANG $\|$ was observed in the kidney, but not in other tissues. Additionally we concluded that myocardial hypertrophy is not necessarily associated with increased $A O$ and renin mRNA expression.

In chapter 4 Wistar rats underwent sham-surgery or an induction of MI, a model for studying the development of cardlac hypertrophy and wound healing. At different times (1-90 days) after surgery the heart was removed and divided into the left ventricle (LV), septum (SE) and right ventricle (RV). Cardiac angiotensin l-converting-enzyme (ACE) mRNA expression was quantified and localized in the infarcted rat heart. Furthermore, ACE-activity and ACE-immunoreactivity was studied following experimental MI. Since cardiac ACE mRNA levels are low, we used a sensitive competitive reverse transcriptase polymerase chain reaction (RT.PCR) for quantifying ACE mRNA levels. We demonstrated a 3-fold increase of ACE MRNA expression in the infarcted LV at 4 and 7 days after MI. However, in the non- 
infarcted myocardium ACE MRNA levels were not different from those in sham animals. At 4 days after MI, ACE mRNA and ACE-immunoreactivity were localized by in situ hybridization (ISH) and immunohistochemistry, respectively. High density of ACE mRNA as well as ACE-immunoreactivity were observed in the border zone of the infarct area, predominantly in endothellal cells, lining capillaries. In the noninfarcted and sham animals ACE mANA and ACE-immunoreactivity were observed in the endothellal cells of larger vessels. Cardliac ACE-activity, measured at 7 and 90 days after MI, was increased 3-fold at these times in the infarcted $L V$, but not in the SE and RV, when compared to sham animals. From these data we concluded that intracardiac ACE does not play a dominant role in the development of cardiac hypertrophy following $\mathrm{MI}$ in the rat. Furthermore, we suggested that intracardiac ACE may play a role in wound healing following $M I$.

In chapter 5 we studied the expression and localization of renin mRNA in the rat heart at different times (1-90 days) after MI. WKY rats underwent sham- or MIsurgery. By competitive RT-PCR cardiac renin mRNA levels were quantified. Atrial natriuretic factor (ANF), a marker for cardiac hypertrophy, was determined by Northern hybridization analysis, in the different compartments of the heart at 1,7 and 90 days following surgery. In sham animals cardiac renin mRNA levels were extremely low and could only be quantified in some of the animals. However, renin mANA levels were higher in the infarcted LV. At 2, 4 and 7 days after $M I$, renin mRNA levels were respectively 4,17 and 8 -fold higher in the infarcted LV. In the non-infarcted hypertrophied myocardium renin mPNA expression was extremely low and indistinguishable from renin mRNA levels in sham animals. At other times after Mll there was no difference in renin mRNA expression when compared to sham animals. Renin mRNA was localized in the heart by ISH at 4 days after $\mathrm{MI}$, the time with the highest renin mRNA levels (wide supra). A high density of renin mRNA was observed in the border zone of the infarct area. In this area renin mRNA was most probably localized in (myo)fibroblasts, but not in cardiomyocytes nor in endothelial cells. In the non-infarcted myocardium renin MRNA expression was very Iow and indistinguishable from the background labeling. ANF MRNA expression increased 2 fold in all compartments of the heart at 1,7 and 90 days after $M$. The low amounts of renin MRNA in the non-infarcted hypertrophied myocardium indicate that the intracardiac synthesis of renin does not play a important role in the development of cardiac hypertrophy in the rat heart following MI. However, the increased renin mRNA expression in the border zone of the infarct area suggests a role for intracardiac synthesized renin in wound healing.

In chapter 6 the expression and localization of AO mRNA was studied in WKY rats in the infarcted rat heart. As ACE and renin, AO mRNA was quantified and localized at different times in the different compartments of the heart after sham- or Ml-surgery. Since these were the same animals as in chapter 5, ANF mRNA expression was increased in the different compartments of the heart, following $M$ (vide supra) By competitive RT-PCR we demonstrated that AO mRNA levels were 
extremely low and that those were not changed following $M \|$ in the different compartments of the heart at any time after surgery. ISH revealed an overall low density of $A O$ mRNA in the myocardium, with a somewhat higher density of $\mathrm{AO}$ mANA labeling in the epicardium. These data demonstrate that intracardiac AO gene is not activated after $M \|$ in the rat heart, suggesting that intracardiac synthesis of $\mathrm{AO}$ does not play a dominant role in the development of cardiac hypertrophy or infarct healing in the rat heart after MI.

In chapter 7 we investigated the feedback regulation of the expression of the components of the intracardiac and systemic RAS by interference with the RAS in WKY rats following MI, with or without treatment with the ACE-inhibitor captopril. At 7 days after surgery rats were sacrificed and the different compartments of the heart, lungs, liver and kidneys were removed. Cardiac AO, renin and ACE MRNA, and renal renin mRNA were quantified by the competitive RT-PCR. Hepatic angiotensinogen, pulmonary ACE and cardiac ANF mANA expression were quantified by Northern hybridization analysis. At 7 days after $\mathrm{MI}_{\text {n }}$ we found an 8 -fold increase of renin mRNA expression and a 3 -fold increase of ACE mRNA expression in the infarcted LV. However, as discussed in chapter 6 we did not find a difference in cardiac angiotensinogen mRNA expression between infarcted and sham animals. Hepatic AO mRNA levels were not changed following ML. Renall renin and pulmonary ACE MRNA expression increased respectively 3 and 1.7 fold following MI. Seven days of captoprill treatment had no effect on the intracardiac expression of the components of the RAS. In sham animals captopril treatment resulted in an increase of renal renin mRNA, whereas it had no effect on hepatic $A O$ and pulmonary ACE mRNA levels. The increase of pulmonary ACE in infarcted animals was suppressed after treatment with captopril. ANF mRNA expression was increased in all compartments of the heart after Ml. However, captopril treatment of the MI-animals resulted did not completely suppres ANF MRNA expression in the different compartments. These data indicate an activation of the intracardiac and the systemic renin and ACE genes, but not of $\mathrm{AO}$ following MI. Furthermore these data suggest a differential feedback regulation of the intracardiac and systemic RAS in infarcted and sham animals.

In summary, the data presented in this thesis show that activation of the components of the intracardiac RAS does not occur in the non-infarcted hypertrophied myocardium, indicating that the intracardiac RAS does not play a dominant role in the development of cardiac hypertrophy following $\mathrm{Ml}$ in the rat. However, the intracardiac activation of the renin and ACE genes in the border zone of the infarct area suggests a role for the intracardiac RAS in wound healing. Furthermore, the differential effects of captopril treatment on the intracardiac and systemic RAS in infarcted rats, suggests that the intracardiac RAS in the infarcted rat is less sensitive for ACE-inhibition than the systemic RAS. 


\section{SAMENVATTING}

Cardiale hypertrofie (het toenemen van de massa van de hartspier) leidt tot een verhoogde morbiditeit en mortaliteit. Hypertensie en myocard infarct (MI) zijn bijvoorbeeld belangrijke oorzaken van cardiale hypertrofie. Er zijn aanwijzingen dat het renine-angiotensine-systeem (RAS) in het hart (intracardiaal) een belangrijke rol speelt in de ontwikkeling van cardiale hypertrofie. In dit proefschrift zijn experimenten gedaan om het belang van het intracardiale RAS in de ontwikkeling van cardiale hypertrofie te bestuderen. Verder zijn experimenten uitgevoerd om het RAS te bestuderen in fysiologische en pathofysiologische omstandigheden.

In hoofdstuk 3 is de regulatie van angiotensinogeen $(A O)$ en renine, twee componenten van het AAS, bestudeerd in verschillende weefsels, 7 dagen na het afbinden van de aorta (aorta coarctatie), 24 uur na het verwijderen van de 2 nieren (bilaterale nefrectomie) en 24 uur na behandeling met een angiotensin l-convertingenzyme (ACE)-remmer (captopril) in Wistar Kyoto (WKY) ratten. De opzet van deze experimenten is zo gekozen, omdat ze een verschillend effect hebben op het systemische (circulerende) RAS. Elk afzonderlijk experiment resulteerde in verschillende plasma angiotensine II (ANG II) en plasma renine spiegels, twee belangrijke modulatorenin de regulatie van AO en renine productie. Verder leidt aorta coarctatie tot cardiale hypertrofie, waardoor het mogelijk is om de rol van $A O$ en renine in de ontwikkeling van cardiale hypertrofie te bestuderen. Nefrectomie leidde tot een signiflcante verhoging van AO mRNA hoeveelheden in de lever en in de hersenen, terwijl AO mRNA hoeveetheden in de andere onderzochte weefsels niet beinvloed werden. Renine mRNA expressie werd niet beinvloed na nefrectomie in de onderzochte weefsels. Zowel aorta coarctatie als captopril behandeling resulteerden in een verlaagde AO mRNA expressie in de atria van het hart. Geen verschil in $A O$ mRNA expressie werd waargenomen in de andere onderzochte weefsels noch na aorta coarctatie noch na captopril behandeling. Opnieuw was ook na aorta coarctatie geen verschil waarneembaar in renine MANA expressie in de verschillende weefsels. Renale renine IRNA expressie was verhoogd na captopril behandeling. We concludeerden dat er een verschillende regulatie van AO en renine MRNA bestaat in de verscheldene bestudeerde weefsels. AO mRNA in de hersenen en de lever blijkt tonisch geremd te worden door renine, terwijl dat niet het geval is in de atria. In de nier werd een negatieve feedback van renine MRNA expressie door ANG $\|$ waargenomen, maar niet in de andere bestudeerde weefsels. Verder concludeerden we dat cardiale hypertrofie, zoals waargenomen na aorta coarctatie, niet noodzakelijk geassocleerd is met een verhoogde AO en renine mANA expressie.

In hootdstuk 4 ondergingen Wistar ratten een sham- of een MI-operatie, een model geschikt voor het bestuderen van cardiale hypertrofie en wondgenezing. Op verschillende tijdstippen na de operatie werd het hart verwijderd en onderverdeeld in linker ventrikel (LV), septum (SE) en rechter ventrikel (RV). We bestudeerden de activatie wan het angiotensim 1-converting-enzyme (ACE) gen (ACE MRNA) en eiwit 
(ACE-activiteit) in het geinfarceerde rattehart. Verder werd ook de lokalisatie van ACE mRNA en het eiwit (ACE-immunoreactiviteit) bestudeerd. Vanwege hel feit dat cardiale ACE mRNA hoeveelheden laag ziljn, hebben we gebruik gemaakt van een zeer gevoelige competitieve reverse transcriptase polymerase chain reaction (RT$P C R$ ) voor het kwantificeren van ACE ImRNA hoeveelheden. Een 3-voudig verhoging van ACE MRNA werd gevonden in de geïnfarceerde $L V, 4$ en 7 dagen na een MI. In het niet-geinfarceerde myocard was er geen verschil in ACE mANA hoeveelheden, vergeleken met de sham dieren. ACE MRNA en ACE-immunoreactiviteit werd op 4 dagen na sham of Ml-operatie gelokaliseerd door middel van respectieve. lijk in situ hybridisatie (ISH) en immunohistochemie. Een hoge ACE MRNA densiteit en een hoge ACE-immunoreactiviteit werd voornamelijk in endotheelcellen waargenomen in het randgebied van het infarct. In het niet-geinfarceerde hart en het sham hart werd ACE mRNA en ACE-immunoreactiviteit waargenomen in endotheelcellen van grotere vaten. De ACE-activiteit in het hart, gemeten op 7 en 90 dagen na de operatie, was 3-voudig verhoogd op beide tijdstippen in de geinfarceerde LV, maar was onveranderd in het SE en RV, vergeleken met de sham dieren. Hieruit concludeerden we dat het intracardiale ACE geen belangrijke rol speelt in de ontwikkeling van hypertrofie na een myocard infarct. Daarentegen suggereerden we dat het intracardiale ACE een rol zou kunnen spelen iln de wondgenezing na een MI.

Im hoofdstuk 5 bestudeerden we de expressie en lokalisatie van renine mRNA in het rattehart na een $M I$ op verschillende tijdstippen. WKY ratten ondergingen een sham- of een Ml-operatie. Door middel van competitieve RT-PCR werden renine MRNA hoeveelheden in het hart gekwantificeerd. Atrial natriuretic factor (ANF), een indicator voor cardiale hypertrofie, werd bepaald door middel van Northern hybridisatie analyse, in de verschillende compartimenten van het hart op 1, 7 en 90 dagen na operatie. In sham dieren waren cardiale renine mRNA hoeveeiheden zeer laag. Echter, renine mRNA hoeveelheden in de geinfarceerde LV waren aanzienlifk hoger. Op 2, 4, en 7 dagen na een MI werd respectievelijk een 4, 17 en 8-voudig verhoging van renine ImRNA hoeveeiheden gevonden in de geinfarceerde LV. Renine mRNA hoeveelheden in het niet genfarceerde hypertrofe hart waren zeer laag en niet te ondercheiden van renine mRNA hoeveelheden in het hart van sham dieren. ANF mRNA expressie was 2 -voudig verhoogd in alle compartimenten op 1,7 en 90 dagen na ML. Renine mRNA werd gelocaliseerd in het hart door middel van ISH op 4 dagen na Ml, het tiljdstip met de hoogste renine mRNA hoeveelheden (vide supra). Een hoge renine mANA densiteit werd waargenomen in het randgebied van het infarct. In dit gebied was renine mANA waarschilnlijk gelocaliseerd in (myo)fibroblasten maar niet in cardiomyocyten en endotheelcellen. In het nlet-genfarceerde hypertrofe myocard was de renine mRNA densiteit zeer laag en niet te onderscheiden van die in het hart van de sham dieren. De lage hoeveelheden van renine MRNA in het hart in het niet-geinfarceerde myocard toont aan dat de intracardiale synthese van renine geen belangrijke rol speelt in de ontwikkeling tot cardiale hypertrofie na een $M I$ in de rat. Echter, de verhoogde renine mANA expres- 
sle in het randgebied van het infarct doet vermoeden dat het intracardiaal glesynthetiseerde renine een role speelt in de wondgenezing na een $M I$ in de rat.

In hoofdstuk 6 werd de expressie en lokalisatie van AO mRNA bestudeerd in WKY ratten na een sham of MI operatie. Aangezien dezelfde dieren waren gebruikt als in hoofdstuk 5 , was de ANF mRNA expressie verhoogd in de compartimenten van het hart na MI (vide supra). Net als ACE en renine werd AO mRNA gekwantificeerd op verschillende tijdstippen na de operatie in de verschillende compartimenten van het hart door middel van competitieve RT-PCR. Er was geen verschil in AO mRNA expressie in de verschillende compartimenten van het hart tussen geinfarceerde en sham dieren op de verschillende tijdstippen na de operatie. ISH toonde een algemeen lage AO mRNA densiteit in het myocard, met een wat hogere $A O$ mRNA densiteit in het epicard. Deze data tonen aan dat intracardiale synthese van AO geen belangrijke rol speelt in de ontwikkeling van cardiale hypertrofie of wondgenezing in het rattehart na een MI.

In hoofdstuk 7 onderzochten we de feedback regulatie van de expressie van de componenten van het intracardiale en het systemische RAS door interventie van het RAS in WKY ratten na een MI, met of zonder behandeling met de ACE-remmer captopril. Zeven dagen na de operatie werden de dieren opgeofferd en de verschillende compartimenten van het hart, de llongen, lever en nieren werden verwijderd. Cardiale $A O$, renine en $A C E$ mRNA en renale renine mRNA werden gekwantificeerd door middel van de competitieve RT-PCR. Hepatische $A O$, pulmonaire ACE en cardiale ANF mRNA expressies werden gekwantificeerd door middel van Northern hybridisatie analyse. 7 dagen na een $\mathrm{Ml}$, vonden we een 8 -voudige verhoging van renine mRNA expressie en een 3-voudige verhoging van ACE mRNA expressie in de geinfarceerde linker ventrikel. Echter, zoals bediscussieerd in hoofdstuk 6 vonden we geen verschil in cardiale AO mRNA expressie tussen infarct en sham dieren. Hepatische AO mRNA was eveneens niet verhoogd na een MI. Renale renine en pulmonaire ACE mRNA expressie waren respectievelijk 3 en 1.7-voudig verhoogd na een MI. Zeven dagen captopril behandeling had geen effect op de intracardiale expressie van de componenten van het RAS. In sham dieren resulteerde captopril behandeling in een verhoogde renale renine mRNA expressie, terwijl dit geen effect had op de hepatische $A O$ en pulmonaire ACE mRNA hoeveelheden. De verhoogde pullmonaire ACE mRNA hoeveelheden werden teruggebracht naar het basale niveau na captopril behandeling. ANF mRNA expressie was verhoogd in alle compartimenten van het hart na MI. Echter, captopril behandeling van de Ml-dieren resulteerde niet in een complete suppressie van de verhoogde ANF mRNA expressle in het hart. Deze data tonen de activatie van de intracardiale en systemische renine en $\mathrm{ACE}$ genen aan na een $\mathrm{MI}$, maar niet van $\mathrm{AO}$. Verder wordt er aangetoond dat er een verschillende feedback regulatie bestaat van het intracardiale en systemische RAS in geïnfarceerde en sham dieren.

Samenvattend, in dit proefschrift wordt aangetoond dat er geen activatie plaats vindt van het intracardiale RAS in het hypertrofe hart, na een MI. Hieruit conclude- 
ren we dat het intracardiale RAS geen belangrijke rol speelt in de ontwikkeling van cardiale hypertrofie na een MI in het rattehart. Echter intracardiale activatie van renine en ACE genen in het randgebied van het infarct in de vroege fase na een infarct, suggereren dat het intracardiale RAS betrokken is bij de wondgenezing na een MI. Verder, de verschillende effecten van captopril behandeling op het intracardiale en systemische RAS in geinfarceerde dieren, suggereert dat het intracardiale RAS in de geinfarceerde rat ongevoeliger is voor ACE-remming dan het systemische RAS. 


\title{
CURRICULUM VITAE
}

\author{
Robert Passier
}

30 september 1967

$1979-1986$

$1986-1990$

1990-1995

1995
Geboren te Bergen op Zoom.

Gymnasium het Juvenaat $H$. Hart te Bergen op Zoom met als eindexamenvakken: Nederlands, Engels, Grieks, Wiskunde, Natuurkunde, Scheikunde en Biologie.

Studie Gezondheidswetenschappen met als afstudeerrichting Blologische Gezondheidkunde aan de Rijksuniversiteit Limburg te Maastricht.

Aanstelling als assistent in opleiding bij de vakgroep Farmacologie, Cardiovascular Research Institute Maastricht, Faculteit der Geneeskunde, Riljksuniversiteit Limburg.

Post-doctoraal medewerker bij dezelfde vakgroep.

\section{LIST OF PUBLICATIONS}

Passier PGJJ, Verluyten MJA, Daemen MJAP, Smits JFM. Regulation of angiotensinogen and renin mANA expression in different tissues of the rat. In: Moaregor $O A$, Sever PS, eds. Current advances in ACE inhibition. v. 3. London: Churchill Livingstone, 1993:150-154.

Passier ACJJ, Smits JFM, Verluyten MJA, Studer R, Drexler H, Daemen MJAP. Activation of angiotensin-converting-enzyme expression in the infarct zone following myocardial infarction. Am J Physiol 1995: 269: H1268-H1276.

Passier RCJJ, Daemen MJAP, Smits JFM. Structural and functional consequences of anglotensin-converting enzyme inhibition and angiotensin type 1-receptor inhibition following myocardial infarction in rats. In: Dhalla NS, ed. The failing heart. New York: Raven Press, 1995:(in press). 
Passier RCJJ, Smits JFM, Verluyten MJA, Daemen MJAP. Expression and localization of renin and angiotensinogen messenger RNA in the rat heart following experimental myocardial infarction. (submitted).

Passier RCJJ, Daemen MJAP, Ulrich MMW, Marx PTJ, Verluyten MJA, Smits JFM. Intracardiac and systemic feedback regulation of the renin-angiotensin-system during early captopril treatment following myocardial infarction in the rat. 1995:(submitted).

Smits JFM, Passier RCJJ, Nelissen-Vrancken HJMG, Cleutjens JPM, Kuizinga MC, Daemen MJAP. Do ACE-inhibitors limit the structural changes in the heart following myocardial infarction? Eur H J 1995: (in press). 



\section{DANKWOORD}

Tensiotte het dankwoord. De totstandkoming van een proefschrift is nooit het werk van een persoon. Via deze weg wil ik dan ook de mensen bedanken, die bij het totstandkomen van dit proefschrift betrokken zijn geweest. Aangezlen het dankwoord onder tijdsdruk in de laatste fase van het proefschrift wordt geschreven (persoonlijke ervaring) is het niet onwaarschijnlijk dat de lijst van dankbetuigingen niet compleet is. Daarom, een ieder die ik vergeten ben in dit dankwoord te melden (uiteraard kom je daar pas over een X-aantal woorden achter), gelleve de volgende regel te lezen.

\section{Bedankt!}

De vergeten personen gehad hebbende, kan ik nu over gaan op een wat minder anonieme dankbetuiging.

Allereerst wil ik mijn promotor Jos Smits en co-promotor Mat Daemen bedanken. Het is niet voor niets dat ik jullie in dezelfde alinea wil bedanken, aangezion jullie beiden veel energie hebben gestoken om mij uiteindelijk tot dit resulaat te loodsen. Het was zeer handig dat jullie gedachtenlijn niet veel verschillend was. De gelijkenis ging door tot in het absurde, door exact dezelfde correcties aan te brengen in de door mlj aangeleverde manuscripten. Het enige verschil was de kleur van de aangebrachte correctie. Jos en Mat, jullie snelle en nauwkeurige handelswijze was prettig en motiverend.

Prof. dr. H. Drexler and Prof. dr. T. Unger, I would like to thank You for reading the manuscript and Prof. dr. Drexler I would also like to thank You for the opportunity You gave me to work in your lab. This period helped me solving my problems with the competitive RT-PCR.

Ook de andere leden van de beoordelingscommissie, Prof. dr. P.W. de Leeuw, Prof. dr. J.W. Arends en Prof. dr. H.J.J. Wellens wil ik bedanken voor het beoordelen van het manuscript

Monique, het moet frustrerend geweest zijn om te zien dat het telkenmale schoon achterlaten van je labtafel niet aanspoorde tot gelijke daden. Ik moest het meer hebben van de lente-en herfst schoonmaak. Je hebt me van het begin af aan geholpen en jouw aandeel is zichtbaar in elk hoofdstuk.

Magda, vooral in de periode dat ik aan het schrijven was, heb jij geholpen om het werk op het lab door te laten gaan. Bovendien stond je altijd klaar om allerlei problemen (voornamelijk moleculaire biologische) te bespreken.

Patrick, je hebt vooral in de laatste fase enthousiast gewerkt om de laatste gegevens te verkrijgen. Cor, zoals bijna in elk proefschrift word je bedankt voor je inbreng in alles wat maar met computers te maken heeft. Jack en Ellen, bedankt voor het kritisch nalezen van het manuscript en voor de vele nuttige tips. Anique, bedankt 
voor de in situ hybridisaties. Peter Lijnen, ik wil jou ook bedanken voor jouw steun ir de competitieve RT-PCR. Jaques, Peter, Carolien en Elsbeth, bedankt voor he verrichten van de vele operaties.

Verder will ik de mensen van de vakgroep Pathologie en Farmacologie bedanken die in meer of mindere mate bij hebben gedragen aan de gezellige werksfeer.

Last, but not least, Sylvia, vooral het laatste jaar is onze vrije tijd wat karig geweest Bedankt voor je engelengeduld en je steun. Op naar jouw promotie!

Robert Passier

23 november, 1995. 